OAK RIDGE NATIONAL LABORATORY

\section{MARTI MARUETRA}

\section{MANAGED BY}

MARTIN MARIETTA ENERGY SYSTEMS, INC. FOR THE UNITED STATES DEPARTMENT OF ENERGY
Postirradiation Evaluation§ df 1 Capsules HANS-1 and HANS-2 Irradiated in the HFIR Target Region in Support of Fuel Development for the Advanced Neutron Source

\author{
G. L. Hofman \\ G. L. Copeland \\ J. L. Snelgrove
}

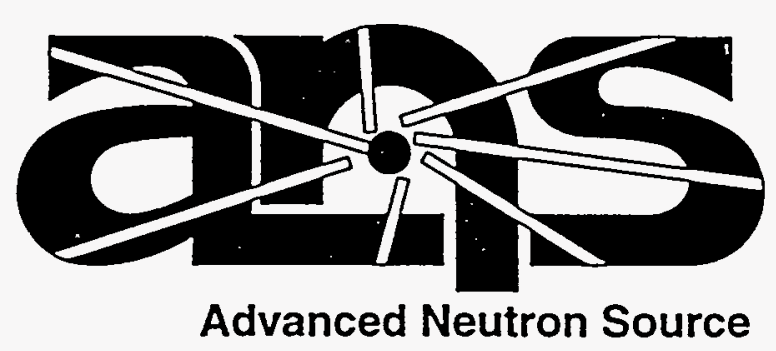


This report has been reproduced directly from the best available copy.

Available to DOE and DOE contractors from the Office of Scientific and Technical Information, P.O. Box 62, Oak Ridge, TN 37831; prices available from (615) 576-8401. FTS 626-8401.

Available to the public from the National Technical Information Service, U.S. Department of Commerce, 5285 Port Royal Rd., Springfield, VA 22161.

This report was prepared as an account of work sponsored by an agency of the United States Government. Neither the United States Government nor any agency thereof, nor any of their employees, makes any warranty, express or implied, or assumes any legal liability or responsibility for the accuracy, completeness, or usefulness of any information, apparatus, product, or process disclosed, or represents that its use would not infringe privately owned rights. Reference herein to any specific commercial product, process, or service by trade name, trademark, manufacturer, or otherwise, does not necessarily constitute or imply its endorsement, recommendation, or favoring by the United States Government or any agency thereof. The views and opinions of authors expressed herein do not necessarily state or reflect those of the United States Government or any agency thereof. 


\title{
POSTIRRADIATION EVALUATIONS OF CAPSULES HANS-1 AND HANS-2 \\ IRRADIATED IN THE HFIR TARGET REGION IN SUPPORT OF FUEL DEVELOPMENT FOR THE ADVANCED NEUTRON SOURCE
}

\author{
G. L. Hofman* \\ G. L. Copeland \\ J. L. Snelgrove* \\ *Argonne National Laboratory \\ 9700 Cass Avenue \\ Argonne, Illinois 60439
}

August 1995

\author{
Prepared by \\ OAK RIDGE NATIONAL LABORATORY \\ Oak Ridge, Tennessee 37831-6285 \\ managed by \\ LOCKHEED MARTIN ENERGY SYSTEMS, INC. \\ for the \\ U.S. DEPARTMENT OF ENERGY \\ under contract DE-AC05-84OR21400
}





\section{CONTENTS}

LIST OF FIGURES $\ldots \ldots \ldots \ldots \ldots \ldots \ldots \ldots \ldots \ldots \ldots \ldots \ldots \ldots \ldots \ldots \ldots \ldots$

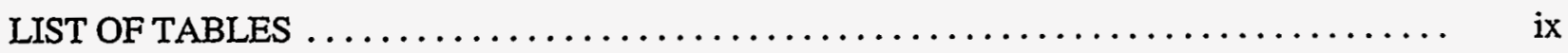

ACRONYMS $\ldots \ldots \ldots \ldots \ldots \ldots \ldots \ldots \ldots \ldots \ldots \ldots \ldots \ldots \ldots \ldots \ldots \ldots \ldots \ldots \ldots \ldots \ldots \ldots \ldots \ldots \ldots$

ABSTRACT $\ldots \ldots \ldots \ldots \ldots \ldots \ldots \ldots \ldots \ldots \ldots \ldots \ldots \ldots \ldots \ldots \ldots \ldots \ldots \ldots \ldots \ldots \ldots \ldots \ldots$

1. INTRODUCTION $\ldots \ldots \ldots \ldots \ldots \ldots \ldots \ldots \ldots \ldots \ldots \ldots \ldots \ldots \ldots \ldots \ldots \ldots \ldots \ldots \ldots \ldots \ldots$

2. DESCRIPTION AND DESIGN OF FUEL HOLDERS AND CAPSULES $\ldots \ldots \ldots \ldots \ldots \ldots$.

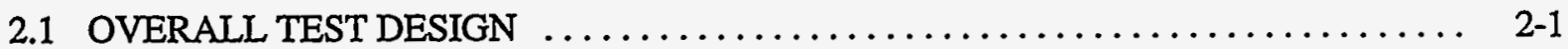

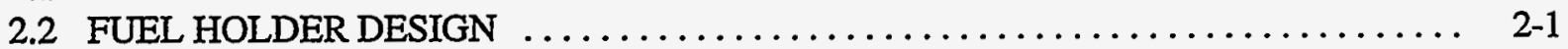

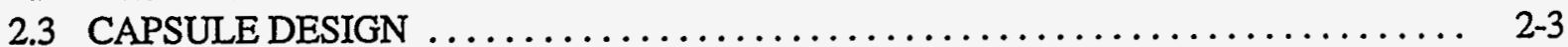

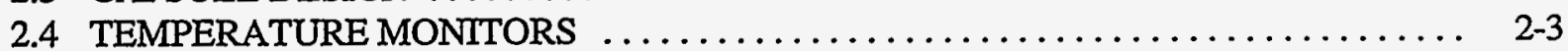

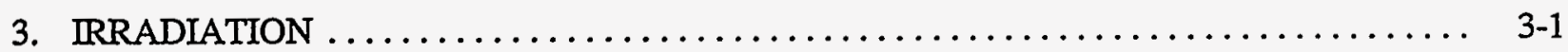

4. POSTIRRADIATION EXAMINATIONS $\ldots \ldots \ldots \ldots \ldots \ldots \ldots \ldots \ldots \ldots \ldots \ldots \ldots \ldots \ldots \ldots \ldots \ldots$

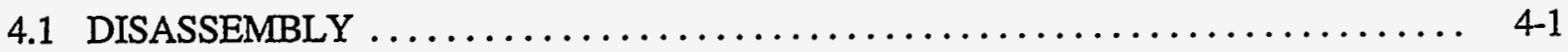

4.2 EVALUATION OF TEMPERATURE MONITORS $\ldots \ldots \ldots \ldots \ldots \ldots \ldots \ldots \ldots \ldots \ldots \ldots \ldots$

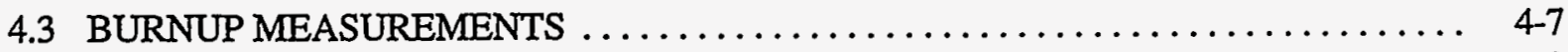

4.4 MICROSTRUCTURAL EXAMINATIONS $\ldots \ldots \ldots \ldots \ldots \ldots \ldots \ldots \ldots \ldots \ldots \ldots \ldots$. 4.8

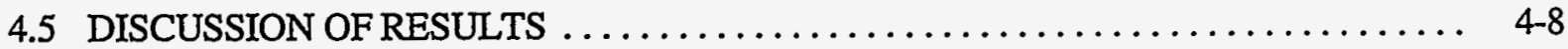

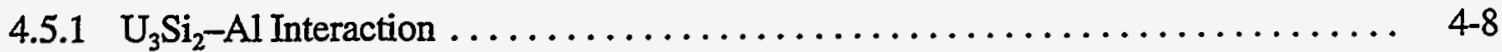

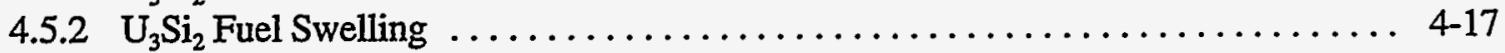

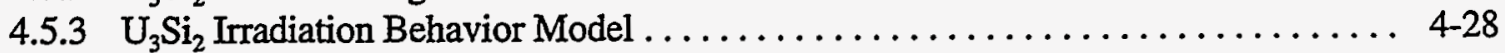

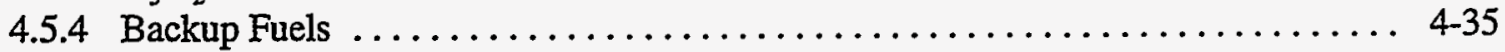

5. SUMMARY AND CONCLUSIONS $\ldots \ldots \ldots \ldots \ldots \ldots \ldots \ldots \ldots \ldots \ldots \ldots \ldots \ldots \ldots \ldots \ldots \ldots \ldots$

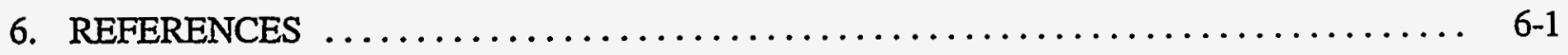

Appendix A. CHEMICAL ANALYSIS DATA FOR FUEL HOLDER MATERIALS $\ldots \ldots \ldots$ A-1

Appendix B. SUPPLEMENTARY OPTICAL AND SCANNING ELECTRON MICROGRAPHS OF HANS-1 AND HANS-2 FUEL SAMPLE $\ldots \ldots \ldots \ldots \ldots \ldots \ldots \ldots$ B-1 
. 


\section{LIST OF FIGURES}

Figure

Page

1-1 Fuel irradiation conditions for the ANS preconceptual core compared to $\mathrm{U}_{3} \mathrm{Si}_{2}$ irradiation experience at the beginning of the ANS Project-fuel particle basis

1.2 Fuel irradiation conditions for the ANS preconceptual core compared to $\mathrm{U}_{3} \mathrm{Si}_{2}$ irradiation experience at the beginning of the ANS Project-fuel meat basis

1.3 Swelling of $\mathrm{U}_{3} \mathrm{Si}_{2}$ of various enrichments and fuel dispersion loadings as a function

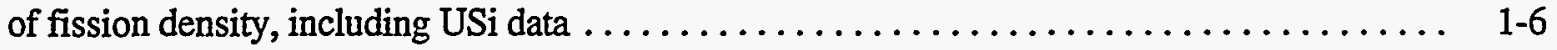

2.1 Drawing of HANS specimen subassembly $\ldots \ldots \ldots \ldots \ldots \ldots \ldots \ldots \ldots \ldots \ldots \ldots \ldots \ldots \ldots \ldots \ldots \ldots$

2.2 Layout of a HANS capsule and its contents prior to loading $\ldots \ldots \ldots \ldots \ldots \ldots \ldots \ldots$

2.3 A closer view of the HANS fuel holder with an end spacer, spacer, axial insulator, and $\mathrm{SiC}$ temperature monitor with its insulator $\ldots \ldots \ldots \ldots \ldots \ldots \ldots \ldots \ldots$

4.1 A section of the HANS-1 capsule tube from holder 18 and a section from holder 16 containing a Mycalex spacer and a Macor insulator .

4.2 Spacer and insulator from holder 18 showing cracks in Mycalex spacer before attempt to remove from tubing of the HANS-1 experiment

4.3 Crumbled Mycalex spacer and Macor insulator (disk) from holder 17 of the HANS-1

experiment

4.4 Erratic data obtained during the postirradiation annealing of the $\mathrm{SiC}$ monitor from HANS-1 holder 6

4.5 Good data obtained during the postirradiation annealing of the $\mathrm{SiC}$ monitor from HANS-1 holder 14

4.6 Good data obtained during the postirradiation annealing of the $\mathrm{SiC}$ monitor from HLANS-2 holder 1

4.7 Microstructure of LEU and HEU dispersion fuel irradiated in the ORR, showing Al-fuel interdiffusion zone surrounding fuel particles: (a) LEU, 95\% burnup; (b) HEU, $42 \%$ burnup; (c) HEU, $63 \%$ burnup .

4.8 Optical and SEM images of longitudinal section through HANS sample, showing areas with no Al-fuel contact

4.9 Isothermal section of the U-Al-Si system at $400^{\circ} \mathrm{C}$

4.10 Width of the $\mathrm{Al}-\mathrm{U}_{3} \mathrm{Si}_{2}$ interaction zone as a function of temperature 4-14 
4.11 Measured $\mathrm{Al}_{-} \mathrm{U}_{3} \mathrm{Si}_{2}$ interaction zone width as a function of fission density $\left(\mathrm{T}<250^{\circ} \mathrm{C}\right) \ldots \ldots$ 4- 15

4.12 Microstructure of depleted $\mathrm{U}_{3} \mathrm{Si}_{2}-\mathrm{Al}$ fuel plates irradiated for $\sim 250 \mathrm{~d}$ in the ORR, showing

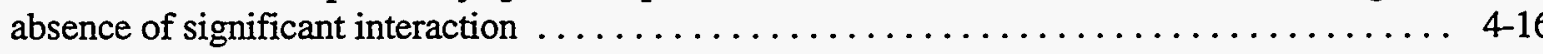

4.13 Microscructure of $\mathrm{U}_{3} \mathrm{Si}_{2}$ fuel particles irradiated at 250 and $425^{\circ} \mathrm{C}$ the HANS- 1 experiment, showing bubble-free interaction zone $\ldots \ldots \ldots \ldots \ldots \ldots \ldots \ldots \ldots \ldots \ldots \ldots \ldots \ldots \ldots \ldots \ldots$

4.14 SEM image of the interaction zone in $\mathrm{U}_{3} \mathrm{Si}_{2}$, showing presence of two zones $\ldots \ldots \ldots$ 4-19

4.15 U-Si phase diagram and change in $\mathrm{U} / \mathrm{Si}$ ratio as $\mathrm{HEU} \mathrm{U}_{3} \mathrm{Si}$ and $\mathrm{U}_{3} \mathrm{Si}_{2}$ are burned $\ldots \ldots \ldots$ 4-20

$4.16 \mathrm{X}$-ray energy spectra of HANS-1 samples 17 and $18 \ldots \ldots \ldots \ldots \ldots \ldots \ldots \ldots \ldots \ldots \ldots$

4.17 Swelling behavior of $\mathrm{U}_{3} \mathrm{Si}_{2} \ldots \ldots \ldots \ldots \ldots \ldots \ldots \ldots \ldots \ldots \ldots \ldots \ldots \ldots \ldots \ldots \ldots \ldots$

4.18 SEM images of $\mathrm{U}_{3} \mathrm{Si}_{2}$, showing evolution of fission gas bubbles $\ldots \ldots \ldots \ldots \ldots \ldots \ldots$

4.19 Fission gas bubble distributions in $\mathrm{HEU} \mathrm{U}_{3} \mathrm{Si}_{2}$ irradiated in the ORR to $9 \times 10^{27}$ and $16 \times 10^{27}$

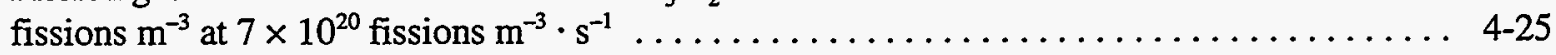

4.20 Fission gas bubble distributions of LEU (upper) and $\mathrm{HEU}$ (lower) $\mathrm{U}_{3} \mathrm{Si}_{2}$ irradiated in

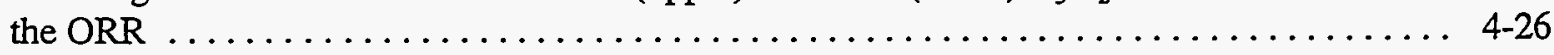

4.21 Microstructures of $\mathrm{U}_{3} \mathrm{Si}_{2}$ fuel particles irradiated in the HANS- 1 experiment at 250 and $425^{\circ} \mathrm{C}$, showing the presence of large bubbles at the centers of the fuel particles . . . . 4-27

4.22 Serial sections through a $\mathrm{U}_{3} \mathrm{Si}_{2}$ fuel particle irradiated in the HANS- 1 experiment at

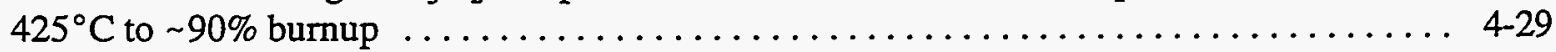

4.23 Bubble morphology in a $\mathrm{U}_{3} \mathrm{Si}_{2}$ fuel particle irradiated in the HANS-1 experiment at $250^{\circ} \mathrm{C}$ to $\sim 85 \%$ burnup, showing region of small, uniform bubbles $\ldots \ldots \ldots \ldots \ldots \ldots .31$

4.24 Microstructural zones in $\mathrm{U}_{3} \mathrm{Si}_{2}$ irradiated in the HANS-1 experiment to $~ 90 \%$ burnup . . . . . 4-32

4.25 Evidence of small grains in a $\mathrm{U}_{3} \mathrm{Si}_{2}$ fuel particle irradiated in the HANS-1 experiment . . . . . 4-33

4.26 Various zones described in the $U_{3} \mathrm{Si}_{2}$ irradiation behavior model $\ldots \ldots \ldots \ldots \ldots \ldots \ldots$. $\ldots \ldots$

4.27 Microstructure of $\mathrm{U}_{3} \mathrm{Si}$ irradiated in the HANS-1 experiment at $375^{\circ} \mathrm{C}$ to $\sim 86 \%$ burnup, showing the absence of large fission gas bubbles 
4.28 Microstructure of $\mathrm{U}_{3} \mathrm{O}_{8}$ irradiated in the HANS-2 experiment at $425^{\circ} \mathrm{C}$ to $\sim 72 \%$ burnup, showing the absence of large fission gas bubbles $\ldots \ldots \ldots \ldots \ldots \ldots \ldots \ldots \ldots \ldots \ldots \ldots \ldots$

4.29 Microstructure of $\mathrm{UAl}_{\mathrm{x}}$ irradiated in the HANS-2 experiment at $425^{\circ} \mathrm{C}$ to $\sim 90 \%$ burnup, showing the presence of large fission gas bubbles

4.30 Microstructure of $\mathrm{UAl}_{\mathrm{x}}$ irradiated in the HANS-2 experiment at $250^{\circ} \mathrm{C}$ to $\sim 84 \%$ 



\section{LIST OF TABLES}

Table

Page

2.1 Fuel holder diameters and calculated irradiation temperatures $\ldots \ldots \ldots \ldots \ldots \ldots \ldots \ldots$

2.2 Density and composition of fuel particles irradiated in HANS-1 and HANS-2 $\ldots \ldots \ldots \ldots$

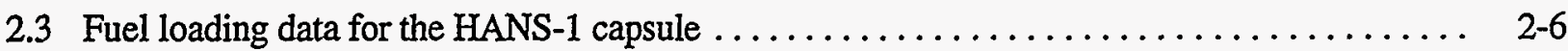

2.4 Fuel loading data for the HANS- 2 capsule $\ldots \ldots \ldots \ldots \ldots \ldots \ldots \ldots \ldots \ldots \ldots \ldots \ldots \ldots$

2.5 Melt monitors used in the HANS- 2 experiment $\ldots \ldots \ldots \ldots \ldots \ldots \ldots \ldots \ldots \ldots \ldots$

3.1 Initial fission rate and final burnup and fission density in the fuel particles . . . . . . . $3-2$

4.1 Temperature monitor evaluation for HANS-1 and HANS $-2 \ldots \ldots \ldots \ldots \ldots \ldots \ldots$

4.2 Burnup evaluation for HANS-1 holders 10 and $17 \ldots \ldots \ldots \ldots \ldots \ldots \ldots \ldots$

4.3 Microstructural examinations performed $\ldots \ldots \ldots \ldots \ldots \ldots \ldots \ldots \ldots \ldots \ldots \ldots \ldots . . \ldots \ldots$

4.4 Compositional analysis by SEM-EDX of several $\mathrm{U}_{3} \mathrm{Si}_{2}$ samples from the HANS-1 experiment . . . . . . . . . . . . . .

4.5 Electron microprobe measurements on $\mathrm{U}_{3} \mathrm{Si}_{2}$ sample 17 from the HANS- 1

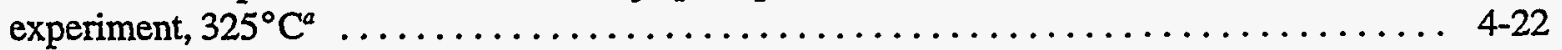




\section{ACRONYMS}

$\begin{array}{ll}\text { ANL } & \text { Argonne National Laboratory } \\ \text { ANS } & \text { Advanced Neutron Source } \\ \text { B\&W } & \text { Babcock and Wilcox Company } \\ \text { CERCA } & \text { Compagnie pour l'Etude et la Realization de Combustibles Atomiques, Romans-sur-Isere, } \\ & \text { France } \\ \text { dph } & \text { diamond-pyramid hardness } \\ \text { EDX } & \text { energy-dispersive X-ray analysis } \\ \text { EMP } & \text { electron microprobe } \\ \text { HEU } & \text { highly enriched uranium } \\ \text { HFIR } & \text { High Flux Isotope Reactor } \\ \text { LEU } & \text { low-enriched uranium } \\ \text { NUKEM } & \text { NUKEM GmbH, Federal Republic of Germany } \\ \text { ORNL } & \text { Oak Ridge National Laboratory } \\ \text { ORR } & \text { Oak Ridge Research Reactor } \\ \text { RERTR } & \text { Reduced Enrichment Research and Test Reactor } \\ \text { SEM } & \text { scanning electron microscope }\end{array}$




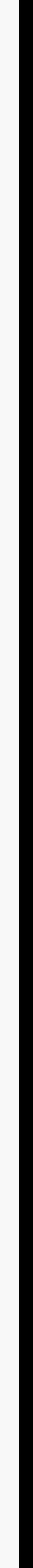




\begin{abstract}
This report describes the design, fabrication, irradiation, and evaluation of two capsule tests containing $\mathrm{U}_{3} \mathrm{Si}_{2}$ fuel particles in contact with aluminum. The tests were in support of fuel qualification for the Advanced Neutron Source (ANS) reactor, a high-powered research reactor that was planned for the Oak Ridge National Laboratory. At the time of these tests, the fuel consisted of $\mathrm{U}_{3} \mathrm{Si}_{2}$ containing highly enriched uranium dispersed in aluminum at a volume fraction of $\sim 0.15$. The extremely high thermal flux in the target region of the High Flux Isotope Reactor provided up to 90\% burnup in one 23-d cycle.

Temperatures up to $450^{\circ} \mathrm{C}$ were maintained by gamma heating. Passive $\mathrm{SiC}$ temperature monitors were employed. The very small specimen size allowed only microstructural examination of the fuel particles but also allowed many specimens to be tested at a range of temperatures. The determination of fission gas bubble morphology by microstructural examination has been beneficial in developing a fuel performance model that allows prediction of fuel performance under these extreme conditions. The results indicate that performance of the reference fuel would be satisfactory under the ANS conditions. In addition to $\mathrm{U}_{3} \mathrm{Si}_{2}$, particles of $\mathrm{U}_{3} \mathrm{Si}, \mathrm{UAl}_{2}, \mathrm{UAl}_{x}$, and $\mathrm{U}_{3} \mathrm{O}_{8}$ were tested.
\end{abstract}




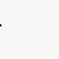




\section{INTRODUCTION}

The Advanced Neutron Source (ANS) is being designed as a user-oriented neutron research laboratory around the most intense continuous beams of thermal and subthermal neutrons in the world. The ANS is based on a new research reactor of about 330-MW fission power with an unprecedented peak thermal flux of $7 \times 10^{19} \mathrm{~m}^{-2} \cdot \mathrm{s}^{-1}$. There also will be extensive facilities for materials irradiation, isotope production, and analytical chemistry.

The reactor core for the ANS consists of cylindrical shell fuel elements. The entire core is replaced for refueling after each cycle $(\sim 17 \mathrm{~d})$. Each element consists of involute fuel plates welded into nonfueled cylindrical side plates. The fuel plates and the coolant channels are $1.27 \mathrm{~mm}$ thick. The fuel plates consist of a "meat" of $\mathrm{U}_{3} \mathrm{Si}_{2}$ particles dispersed in aluminum, a "filler" section of aluminum, and a burnable poison insert on both ends consisting of $\mathrm{B}_{4} \mathrm{C}$ particles dispersed in aluminum. The fuel meat varies in thickness in both the radial and axial directions. The plates are clad completely with 6061 aluminum alloy, and the sideplates are 6061 alloy.

An early core design for the ANS was an extremely compact core with very high specific uranium density. ${ }^{1}$ The core volume was $35 \mathrm{~L}$ with a highly enriched uranium loading of $\sim 19 \mathrm{~kg}$, necessitating a uranium loading in the meat of $\sim 3.5 \mathrm{Mg} / \mathrm{m}^{3}$. The only promising fuel for this high density is $\mathrm{U}_{3} \mathrm{Si}_{2}$, which was developed by the Reduced Enrichment Research and Test Reactor (RERTR) program at Argonne National Laboratory (ANL). The data upon which the U. S. Nuclear Regulatory Commission based its approval of the use of the $\mathrm{U}_{3} \mathrm{Si}_{2}$ fuel for conversion (to low-enriched uranium) of licensed nonpower reactors are in the report Safety Evaluation Report Related to the Evaluation of Low-Enriched Uranium Silicide-Aluminum Dispersion Fuel for Use in Non-Power Reactors, NUREG-1313. ${ }^{2}$ The fuel has been shown to perform well at loadings and fission densities beyond those required for the ANS core, although at conditions of fission rate and temperature well below those anticipated for the ANS. Therefore, an irradiation testing program was put into place to verify the performance at conditions as near as possible to those of the ANS. A fuel performance model was developed to consolidate the data from the various types of tests and to predict the performance of the fuel under various conditions.

The ANS conceptual design core ${ }^{3}$ of 1993 was both larger and lower-loaded than the original compact core. This change lowered the uranium density to the level where both $\mathrm{U}_{3} \mathrm{O}_{8}$ and $U \mathrm{UI}_{\mathrm{x}}{ }^{*}$ can be fabricated as dispersions in aluminum. The loading of this core design was originally $1.05 \mathrm{Mg} \mathrm{U} / \mathrm{m}^{3}$, but it gradually increased to about $1.7 \mathrm{Mg} \mathrm{U} / \mathrm{m}^{3}$, which is expected to provide sufficient excess reactivity to account for the losses resulting from experimental facilities in the reflector. ${ }^{\dagger}$ Much irradiation data and experience exist for these fuels in research and test reactors. However, this irradiation experience is also at much lower temperatures and fission rates than those planned for the ANS.

$\mathrm{U}_{3} \mathrm{Si}_{2}$ is retained as the reference fuel for the ANS because the higher particle density yields a lower volume fraction of fuel and thus facilitates fabrication and improves the thermal conductivity and stability of the dispersion. Both $\mathrm{U}_{3} \mathrm{O}_{8}$ and $\mathrm{UAl}_{\mathrm{x}}$ are considered to be viable backup fuels for the conceptual design core and are being included in the early irradiation tests in order to obtain performance data at high temperatures and fission rates. In addition, $\mathrm{UAl}_{2}$ has been included in the tests. As discussed in Sect. 4.5.4, $\mathrm{UAl}_{2}$ converts to $\mathrm{UAl}_{\mathrm{x}}$ during fabrication and irradiation, but may offer some advantage over $\mathrm{UAl}_{\mathrm{x}}$ during fabrication because of its higher density. Based on existing data, $\mathrm{UAl}_{\mathrm{x}}$ appears to be the most stable of all

*A mixture of the intermetallic compounds $\mathrm{UAl}_{2}, \mathrm{UAl}_{3}$, and $\mathrm{UAl}_{4}$, with $\mathrm{x} \approx 3$. Typical compositions are 7-9 wt \% $\mathrm{UAl}_{2}, 79-84 \mathrm{wt} \% \mathrm{UAl}_{3}$, and 9-13 wt \% UAl 4 .

${ }^{\dagger}$ An even larger core consisting of three elements was baselined in December 1994. This core uses uranium enriched to only $50 \%{ }^{235} \mathrm{U}$ and would require a uranium density of $3.5 \mathrm{Mg} \mathrm{U} / \mathrm{m}^{3}$, which eliminates the $\mathrm{U}_{3} \mathrm{O}_{8}$ and $\mathrm{UAl}_{\mathrm{x}}$ from consideration as alternative fuels. This new core design will not be specifically addressed in this report. 
the prospective fuels in its retention of fission gas. Based on experience at $\mathrm{B} \& W$, it appears that $\mathrm{U}_{3} \mathrm{O}_{8}$ may be the fuel most easily fabricated to the exacting tolerances of the ANS. It retains fission gas well and behaves stably up to a level of burnup (perhaps beyond the ANS requirements), which decreases as the fuel loading increases. Fabrication of $\mathrm{U}_{3} \mathrm{Si}_{2}$ is roughly equivalent to fabrication of $\mathrm{UAl}_{3}$. The existing irradiation behavior data for $\mathrm{U}_{3} \mathrm{Si}_{2}$ show behavior similar to the aluminide in that no limits need to be set on burnup; however, the silicide shows some small fission gas bubbles and the aluminide does not. A few samples of the highest-density uranium silicide, $\mathrm{U}_{3} \mathrm{Si}$, were also included in the HANS tests in order to provide data for a general understanding of silicide irradiation behavior. Although $\mathrm{U}_{3} \mathrm{Si}$ was not considered to be a viable fuel for the ANS because earlier tests had shown it susceptible to breakaway swelling, ${ }^{\dagger}$ the results of the HANS irradiations indicate that it might be usable in the ANS (see Sect. 4.5.4).

The irradiation performance data for ${ }_{3} \mathrm{Si}_{2}$ have been generated by the United States' RERTR program, which was established in 1978 to provide the technical means to convert research and test reactors from the use of highly enriched uranium (HEU) fuel to low-enriched (LEU) fuel, ${ }^{4}$ a change requiring greatly increased uranium content to maintain the excess reactivity required for the continued operation of the reactors. To this end, the RERTR program pursued both increasing the volume fraction of existing fuel compounds and developing new, higher-density fuel compounds. In 1978, the highest density fuels in common use in plate-type research reactor fuel elements were dispersions of uranium aluminide $\left(\mathrm{UAl}_{x}\right)$ and uranium oxide $\left(\mathrm{U}_{3} \mathrm{O}_{8}\right)$ in aluminum, with fuel meat densities of 1.7 and $1.3 \mathrm{Mg} \mathrm{U} / \mathrm{m}^{3}$, respectively. These two types of fuels were developed and tested for LEU applications up to their practical fabrication limits of $2.4 \mathrm{Mg} \mathrm{U} / \mathrm{m}^{3}$ for $\mathrm{UAl}_{\mathrm{x}}$ and $3.2 \mathrm{Mg} \mathrm{U} / \mathrm{m}^{3}$ for $\mathrm{U}_{3} \mathrm{O}_{8}$. Still higher fuel densities were required for some applications, and higher-density compounds were investigated for these. The compound $\mathrm{U}_{3} \mathrm{Si}_{2}$ was found to perform extremely well during irradiation and could be fabricated successfully at densities up to at least $4.8 \mathrm{Mg} \mathrm{U} / \mathrm{m}^{3}$.

The development and testing of $\mathrm{U}_{3} \mathrm{Si}_{2}$ in the United States progressed from miniature fuel plates (miniplates), ${ }^{5}$ to experimental elements, ${ }^{6}$ and to a full demonstration core for the Oak Ridge Research Reactor (ORR). ${ }^{7}$ The demonstration core operated for about 15 months and was fueled by elements from three commercial fabricators: NUKEM, ${ }^{\ddagger}$ CERCA," and B\&W. This test program ultimately led to approval by the U.S. Nuclear Regulatory Commission of the use of $\mathrm{U}_{3} \mathrm{Si}_{2}$ for the HEU-to-LEU conversion of licensed nonpower reactors. ${ }^{2}$ The RERTR program involved international cooperation. Miniplates, full-sized plates, and/or test elements were fabricated in France, Germany, Argentina, and Indonesia and tested in reactors in France, Germany, Sweden, the Netherlands, Japan, and Indonesia. Some fabrication and testing has also been done in China and the U.S.S.R.

Summaries of the irradiation experience base for $\mathrm{U}_{3} \mathrm{Si}_{2}$ when the ANS project began are depicted in Figs. 1.1 and 1.2. This base represents 58 miniplates and 85 elements (1,587 full-sized plates), which were carefully evaluated and represent completely satisfactory performance. No plate failures have yet been attributed to the $\mathrm{U}_{3} \mathrm{Si}_{2}-\mathrm{Al}$ fuel dispersion. Figure 1.1 shows fission density in the fuel particles vs uranium density in the meat. Figure 1.2 shows fission density in the meat (combined fuel particles and aluminum matrix) vs uranium density in the meat. Both factors are important in the performance of the fuel during irradiation. The bulk of the data are for high-uranium-density loadings of LEU fuel. Thus, the data extend beyond the range expected for

\footnotetext{
Babcock and Wilcox Company, Lynchburg, Virginia.

"In this report, the term "breakaway swelling" is used to describe a condition characterized by an unstable fission gas bubble morphology in which bubble coarsening and interlinkage can lead to rapid increase in bubble volume. Unless the fuel particles are well-separated by the matrix aluminum (i.e., unless the fuel volume fraction is sufficiently low so that fuel particles cannot grow together over extended areas) or unless sufficient external restraint is applied to the fuel particles, breakaway swelling of the fuel particles can lead to failure of the fuel plate.

${ }^{\ddagger}$ NUKEM GmbH, Hanau, Fed. Rep. of Germany.

** Compagnie pour l'Etude et la Realization de Combustibles Atomiques, Romans-sur-Isere, France.
} 


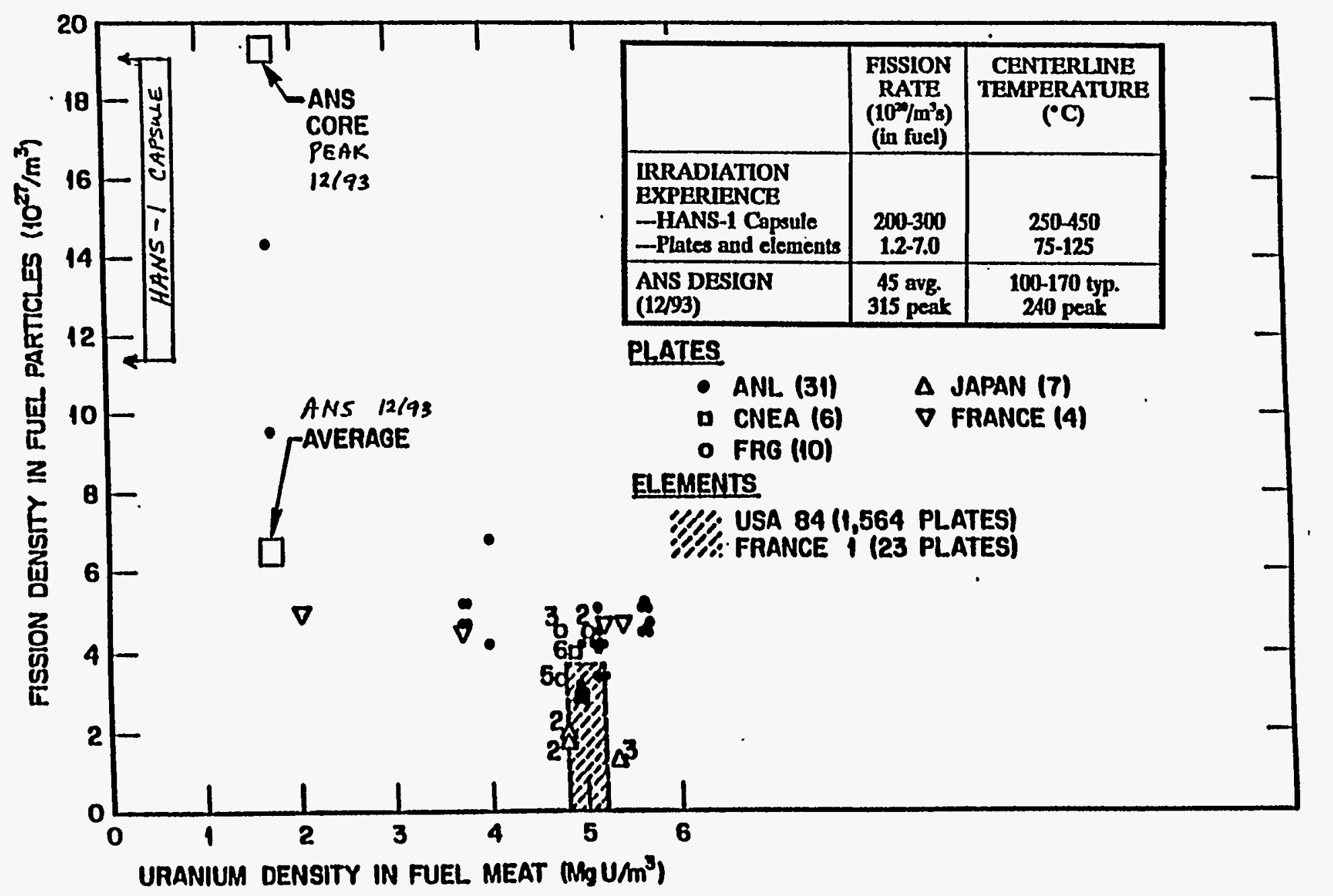

Fig. 1.1. Fuel irradiation conditions for the ANS preconceptual core compared to $\mathrm{U}_{3} \mathrm{Si}_{2}$ irradiation experience at the beginning of the ANS Project-fuel particle basis. 


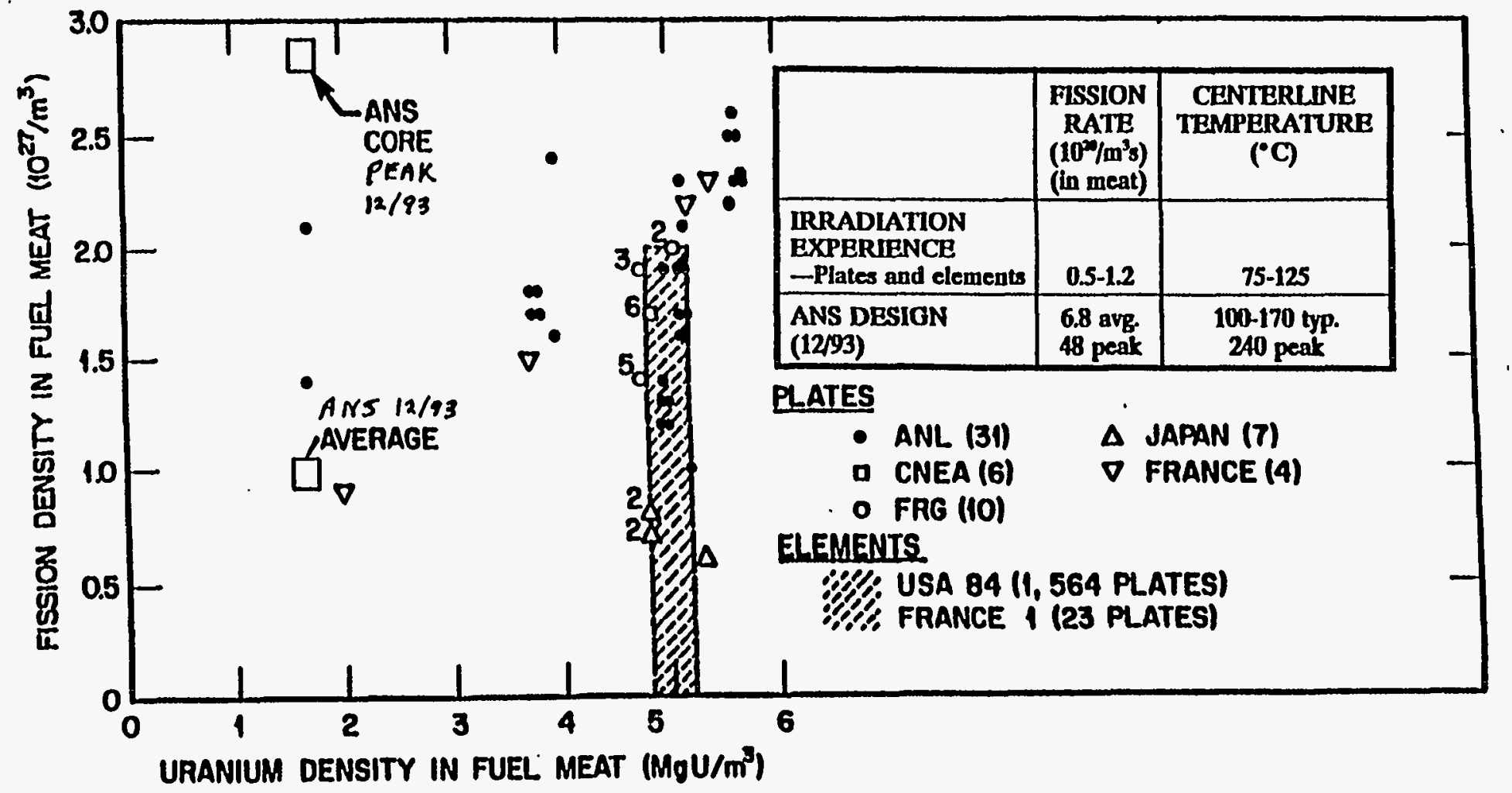

Fig. 1.2. Fuel irradiation conditions for the ANS preconceptual core compared to $U_{3} \mathrm{Si}_{2}$ irradiation experience at the beginning of the ANS Project-fuel meat basis. 
the ANS in terms of fission density in the meat. (The ANS has a low-uranium-density of HEU fuel). Up to $\sim 20 \times 10^{27}$ fissions $/ \mathrm{m}^{3}$ in the particle ( $\sim 90 \%$ burnup) are expected in the ANS in small regions at the edges and ends of the plates, where the meat is very thin. The average for the core is $\sim 9 \times 10^{27}$ fissions $/ \mathrm{m}^{3}$. Since the fuel volume fraction is $\sim 0.15$, the corresponding values are $\sim 3.0$ and $1.4 \times 10^{27}$ fissions $/ \mathrm{m}^{3}$, respectively, in the meat.

Only two miniplates of $\mathrm{HEU} \mathrm{U}_{3} \mathrm{Si}_{2}$ have been irradiated to date. These were irradiated by the RERTR program to give some experience well beyond any burnup possible with LEU. These plates with a meat density of $1.66 \mathrm{Mg} \mathrm{U} / \mathrm{m}^{3}$ ( 0.147 volume fraction) were irradiated in the ORR to burnups of about 42 and $63 \%$, corresponding to 1.4 and $2.1 \times 10^{27}$ fissions $/ \mathrm{m}^{3}$, respectively, in the meat and 9.5 and $14.3 \times 10^{27}$ fissions $/ \mathrm{m}^{3}$, respectively, in the particles. The plates retained good mechanical integrity, and the swelling was somewhat lower than that projected from LEU data. The fuel-meat-swelling values were 4.9 and $11.6 \%$, respectively, and the particle-swelling values were 38 and $84 \%$, respectively. Microstructural examination showed the stable structure typical of $\mathrm{U}_{3} \mathrm{Si}_{2}$. Optical metallography revealed virtually no fission gas bubbles in the fuel particles irradiated to $42 \%$ burnup and a regular distribution of small bubbles in the fuel particles irradiated to $63 \%$ burnup (see Fig. 4.7). Higher magnification examination with the scanning electron microscope (SEM) revealed a stable morphology of very small fission gas bubbles (see, for example, Fig. 4.19).

The swelling of $\mathrm{U}_{3} \mathrm{Si}_{2}$ particles of various enrichments as obtained from miniplate data is shown in Fig. 1.3. The swelling is lower for higher enrichment fuel, as a result of its higher fission rate. It is hypothesized that this is the result of a delay in transition from the lower swelling rate to the higher swelling rate that corresponds to the formation of fission gas bubbles that can be resolved with the SEM $(\sim 30 \mathrm{~nm})$. That is, before the knee of the curve, gas bubbles are not observed. Above the knee of the curve (in the higher swelling rate region), gas bubbles are observed with the SEM. It is hypothesized that this transition is the result of a recrystallization into extremely fine subgrains $\sim 1 \mu \mathrm{m}$ in diameter with the gas bubbles precipitating on the subgrain boundaries. ${ }^{8}$

The performance requirements for the ANS fuel represent a realistic advancement of existing technology. The projected temperatures and fission rates for the ANS are beyond the experience base for any of the research reactor fuels. The primary goal of the irradiation testing program is to validate the performance of the fuel at conditions as close as can be obtained to the temperatures and fission rates of the ANS. The goal of these first two capsule tests is to obtain high-temperature, high-fission-rate irradiation performance data for the three fuel materials being considered. The fuel content in the specimens is kept low to allow placement in the target region of the High Flux Isotope Reactor (HFIR), which has a higher thermal flux than most of the fueled region of ANS. The low fuel content also allows most of the heat to be generated by gamma heating rather than by fission so that the temperature remains nearly constant during the test. The primary evaluation criterion is fission gas bubble morphology as determined by microstructural examination. 


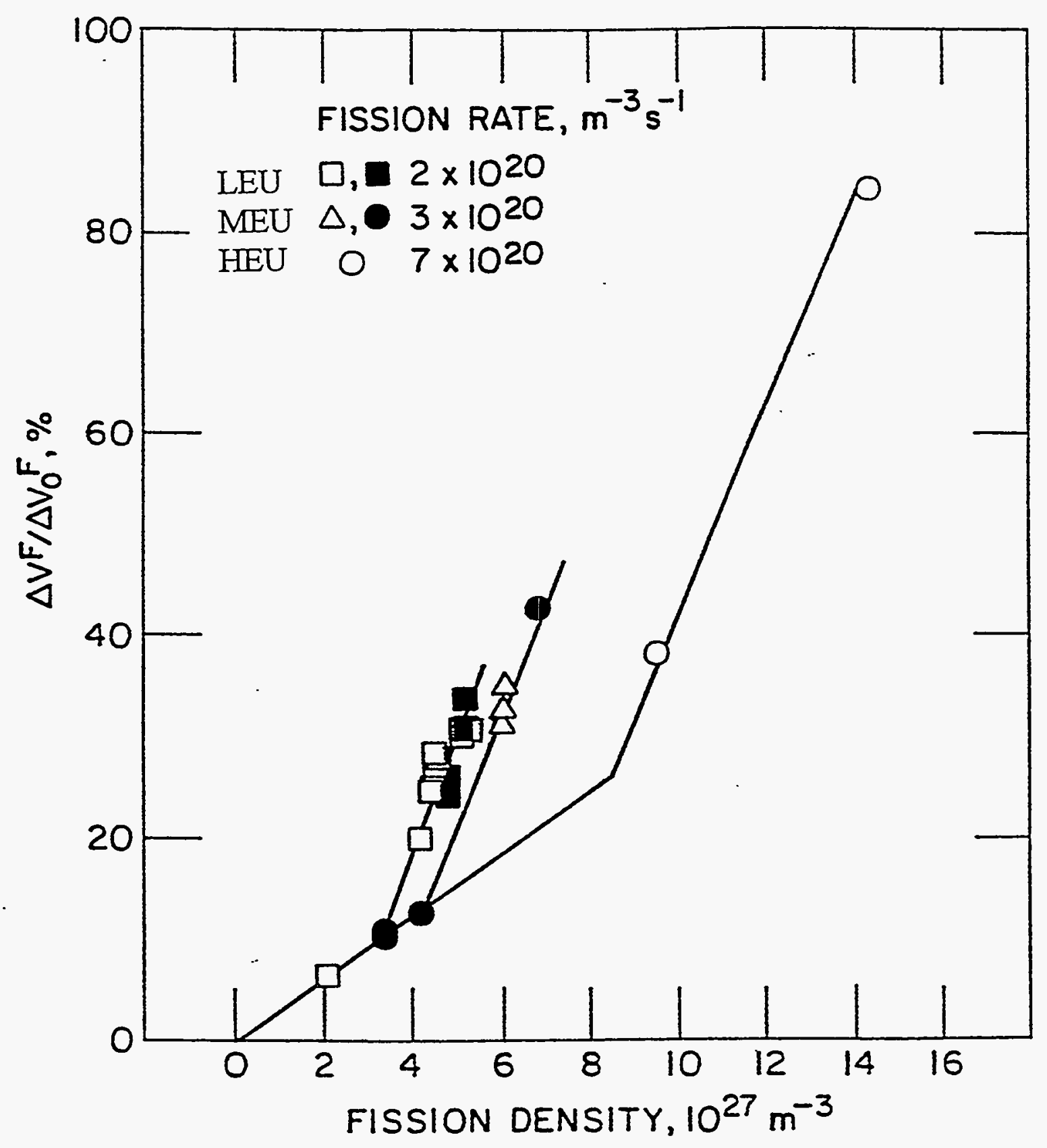

Fig. 1.3. Swelling of $\mathrm{U}_{3} \mathrm{Si}_{2}$ of various enrichments and fuel dispersion loadings as a function of fission density, including USi data. 


\section{DESCRIPTION AND DESIGN OF FUEL HOLDERS AND CAPSULES}

\subsection{OVERALL TEST DESIGN}

As discussed in Sect. 1, a dispersion of $\mathrm{U}_{3} \mathrm{Si}_{2}$ in aluminum was chosen for the ANS because of its high density and because irradiation experience from the RERTR program indicated that the fuel would behave stably in the ANS. However, as shown in Fig. 1.1, even though fission densities approaching the maximum ANS values had been achieved in limited tests, anticipated fission rates and fuel meat temperatures for the ANS design are much higher than had been tested. Therefore, it was imperative that early tests be performed to demonstrate acceptable fuel behavior under ANS conditions.

The problem, of course, was that the neutron flux and power density in portions of the ANS core are significantly higher than those in the fuel testing regions of any existing reactor. From a number of preliminary neutronics investigations, it was clear that only in the target region of the HFIR could ANS fission rates be approached. The $2.4 \times 10^{19} \mathrm{~m}^{-2} \cdot \mathrm{s}^{-1}$ thermal flux in the HFIR target actually approaches the peak in the fuel region of the ANS. However, heat removal capabilities are quite limited there. Fortunately, the RERTR program's investigations had shown that one could straightforwardly infer the behavior of the fuel meat from the behavior of the fuel particles. Therefore, it was concluded that irradiation tests of a small number of fuel particles embedded in aluminum would provide the needed information, while producing manageable amounts of heat. It was also decided to maintain a nearly constant temperature during the experiment in order to simplify determination of any effect of temperature on the irradiation behavior.

These considerations led to the fuel holder and capsule designs discussed below. In order to maintain a nearly constant temperature as the ${ }^{235} \mathrm{U}$ depletes during the irradiation, most of the heat would have to be produced by the nearly constant gamma field in the HFIR target region. The temperatures of the various fuel holders were adjusted by varying the thickness of the gas gap between the holder and the capsule wall. Calculations of fission and gamma heating performed by B. W. Patton of the ORNL Engineering Technology Division indicated that a fuel loading of $0.46 \mathrm{mg}$ of ${ }^{235} \mathrm{U}$ in each fuel holder would result in $90 \%$ of the heat being generated by $\gamma$ rays at the beginning of the irradiation cycle. The approximately $90 \%{ }^{235} \mathrm{U}$ depletion expected during the irradiation cycle was calculated to result in an average temperature decrease of $18^{\circ} \mathrm{C}$ (range 9 to $36^{\circ} \mathrm{C}$ ) for the 18 fuel holders of the HANS-1 experiment. Similar temperature decreases would be expected in the HANS-2 fuel holders during irradiation.

\subsection{FUEL HOLDER DESIGN}

The fuel holder, shown in Fig. 2.1, was machined from Al-6061 alloy. The overall length of each holder is $25.4 \mathrm{~mm}$, and the diameters were such as to give the desired gas gap for temperature control in the capsule (see Sect. 2.3). Each holder contained two 1-mm-high fuel zones located near the axial midplane of the holder in the two 1-mm-diam holes located $180^{\circ}$ apart on a 5.59-mm-diam circle. The fuel zone consisted of a mixture of fuel particles and aluminum powder, compacted under a pressure of $199 \mathrm{MPa}$. It should be noted that dispersion fuel plates are fabricated using a hot roll-bonding process, so there is much more intimate contact and a small amount of reaction between the fuel particles and the aluminum matrix. Hot-rolled samples have been irradiated in the HANS-3 capsule to determine if differences in sample fabrication method are important. Aluminum powder (without fuel) was compacted above and below the fuel zone, using the same compacting pressure. The remainder of each fuel hole was filled with $\mathrm{Al}(>99.5 \%)$ wire, and the holes were sealed by electron beam welding. A silicon carbide temperature monitor occupied the central cavity of each holder, held in place by a stainless steel set screw (average mass $=87 \mathrm{mg}$ ) and an alumina spacer (see Sect. 2.4). As also discussed in 
ORNL-DWG 95M-4560

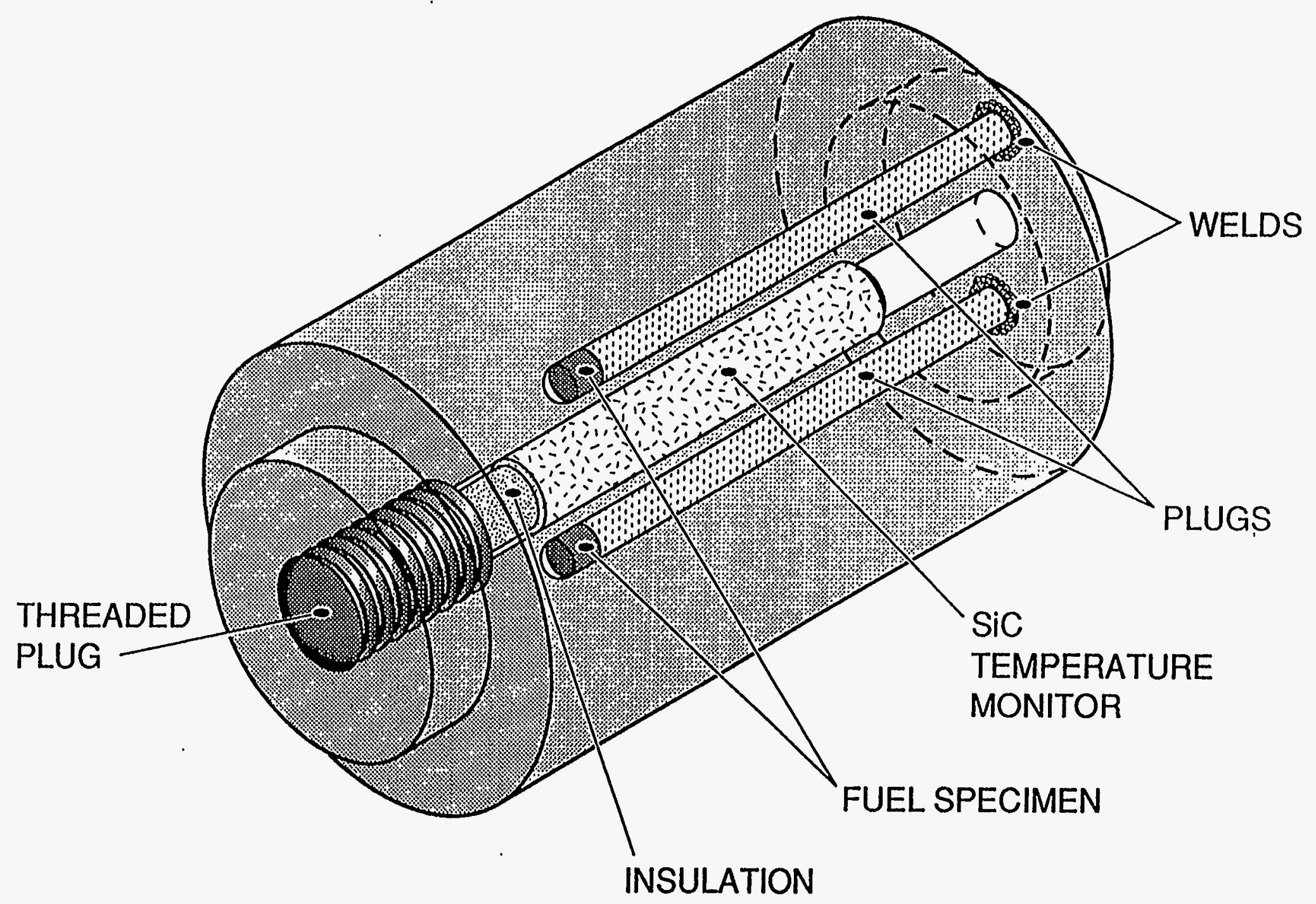

Fig. 2.1. Drawing of HANS specimen subassembly. 
Sect. 2.4, melt monitors were used in five of the HANS-2 fuel holders. The melt monitors were placed in 1.73-mm-diam, 23.83-mm-deep holes located midway between the two fuel holes on the same circle. The fuel holder diameters and calculated temperatures during irradiation are listed in Table 2.1. Information about the HANS-1 and -2 fuel loadings is given in Tables 2.2 through 2.4. The chemical analysis data for the fuel holder materials and the fuels are given in Appendix A.

\subsection{CAPSULE DESIGN}

The capsule used for the HANS-1 and HANS-2 experiments is a standard design that replaces a target rod in the target basket in the central flux trap in the HFIR. It is basically a cylindrical tube of 6061 aluminum whose end fittings are compatible with the HFIR target basket. The tube length is $616 \mathrm{~mm}$, which allows space for 18 fuel holders per capsule. The internal diameter is nominally $13.49 \mathrm{~mm}$. The temperature of the fuel holders is maintained by a gas gap between the holders and the tube wall. This requirement necessitates centering the fuel holders and minimizing axial heat flow, which are accomplished by hexagonal spacers on the ends of the fuel holders contacting the tube at six points and by disk-shaped insulators between the holders. The layout of the capsule and its contents prior to loading is shown in Fig. 2.2. A closer view of the holder with an end spacer, spacer, axial insulator (and SiC temperature monitor with its insulator) is shown in Fig. 2.3. After assembly the capsule was baked out under vacuum, backfilled with pure helium to $\sim 1.3 \mathrm{~atm}$ pressure, and sealed.

The material for the spacers and axial insulators needed a low thermal conductivity and high resistance to irradiation damage to withstand the HFIR target environment. The ceramic materials known to have good irradiation performance (such as $\mathrm{Al}_{2} \mathrm{O}_{3}$ ) have relatively high thermal conductivity. The "machinable ceramics" (glass-bonded mica products) seemed appropriate both for their low thermal conductivities and for their ability to be machined relatively easily into the spacer shapes. However, few data could be found on their irradiation stability. Two products in particular were of interest: Mykroy/Mycalex* grade 1100 amorphous glass-bonded mica with synthetic mica, and Macor, ${ }^{\dagger}$ which is a crystallized glass-bonded mica. No information was found on the irradiation stability of Macor. It contains some boron, which would react to form gaseous products during the test and was thus thought to be unsuitable. The Mycalex product was referred to as being usable in an irradiation environment at a fast neutron fluence up to $5.2 \times 10^{20} \mathrm{~m}^{-2}$. However, an exact source could not be found for these data. ${ }^{9}$ We decided to use the Mycalex for the spacers and Macor for the axial insulators to determine if the products held up. The original assembly procedure for the capsule called for both products to be baked out at $500^{\circ} \mathrm{C}$ after a cleaning process. However, both products swelled to the point that they could not be assembled into the capsule, so the bakeout temperature was lowered to $150^{\circ} \mathrm{C}$, which produced no measurable swelling.

\subsection{TEMPERATURE MONITORS}

Passive temperature monitors were used to simplify the test and to minimize the cost. A silicon carbide cylinder ( $2.3 \mathrm{~mm}$ diam $\times 12.7 \mathrm{~mm}$ long) was inserted into the center of each fuel holder in both tests. The SiC was held captive by a stainless steel set screw separated by an insulator. The set screw was inserted only loosely to ease removal and not to restrain the $\mathrm{SiC}$. The irradiation temperature was determined by postirradiation annealing and measurement of the lengths. The length increases during irradiation. Upon sequential postirradiation annealing, the length should not change until the irradiation temperature is reached and then should decrease linearly until the damage is annealed. ${ }^{10}$

\footnotetext{
"Mykroy/Mycalex, Clifton, N.J.

†Corning Glass Works, Corning, N.Y.
} 
Table 2.1. Fuel holder diameters and calculated irradiation temperatures

\begin{tabular}{|c|c|c|c|c|c|c|c|}
\hline \multirow[b]{2}{*}{ Position } & \multicolumn{4}{|c|}{ HANS-1 capsule } & \multicolumn{3}{|c|}{ HANS-2 cpsule } \\
\hline & $\begin{array}{l}\text { Fuel } \\
\text { type }\end{array}$ & $\begin{array}{c}\text { Holder } \\
\text { diameter } \\
(\mathrm{mm})\end{array}$ & $\begin{array}{l}\text { Calculated } \\
\text { initial } \\
\text { temperature } \\
\left({ }^{\circ} \mathrm{C}\right)\end{array}$ & $\begin{array}{c}\text { Calculated } \\
\text { final } \\
\text { temperature } \\
\left({ }^{\circ} \mathrm{C}\right) \\
\end{array}$ & $\begin{array}{l}\text { Fuel } \\
\text { type }\end{array}$ & $\begin{array}{c}\text { Holder } \\
\text { diameter } \\
(\mathrm{mm})\end{array}$ & $\begin{array}{c}\text { Calculated } \\
\text { initial } \\
\text { temperature } \\
\left({ }^{\circ} \mathrm{C}\right)\end{array}$ \\
\hline 1 & $\mathrm{U}_{3} \mathrm{Si}_{2}$ & 12.238 & 424 & 388 & $\mathrm{U}_{3} \mathrm{O}_{8}$ & 12.273 & 425 \\
\hline 2 & $\mathrm{U}_{3} \mathrm{Si}_{2}$ & 12.794 & 374 & 350 & $\mathrm{UAl}_{2}$ & 12.624 & 425 \\
\hline 3 & $\mathrm{U}_{3} \mathrm{Si}_{2}$ & 13.063 & 324 & 306 & $\mathrm{U}_{3} \mathrm{O}_{8}$ & 13.233 & 250 \\
\hline 4 & $\mathrm{U}_{3} \mathrm{Si}_{2}$ & 13.269 & 250 & 238 & $\mathrm{UAl}_{2}$ & 13.259 & 250 \\
\hline 5 & $\mathrm{U}_{3} \mathrm{Si}$ & 13.335 & 227 & 218 & $\mathrm{U}_{3} \mathrm{O}_{8}$ & 13.167 & 325 \\
\hline 6 & $\mathrm{U}_{3} \mathrm{Si}_{2}$ & 13.315 & 251 & 239 & $\mathrm{UAl}_{2}$ & 13.117 & 375 \\
\hline 7 & $\mathrm{U}_{3} \mathrm{Si}_{2}$ & 13.218 & 324 & 310 & $\mathrm{U}_{3} \mathrm{O}_{8}$ & 13.142 & 375 \\
\hline 8 & $\mathrm{U}_{3} \mathrm{Si}_{2}$ & 13.150 & 374 & 357 & $\mathrm{UAl}_{2}$ & 13.061 & 425 \\
\hline 9 & $\mathrm{U}_{3} \mathrm{Si}_{2}$ & 13.076 & 425 & 406 & $\mathrm{U}_{3} \mathrm{O}_{8}$ & 13.076 & 425 \\
\hline 10 & $\mathrm{U}_{3} \mathrm{Si}_{2}$ & 13.073 & 425 & 406 & $\mathrm{UAl}_{\mathrm{x}}$ & 13.086 & 425 \\
\hline 11 & $\mathrm{U}_{3} \mathrm{Si}_{2}$ & 13.152 & 374 & 357 & $\mathrm{U}_{3} \mathrm{Si}_{2}$ & 13.061 & 425 \\
\hline 12 & $\mathrm{U}_{3} \mathrm{Si}_{2}$ & 13.218 & 324 & 310 & $\mathrm{UAl}_{\mathrm{x}}$ & 13.142 & 375 \\
\hline 13 & $\mathrm{U}_{3} \mathrm{Si}_{2}$ & 13.310 & 251 & 239 & $\mathrm{U}_{3} \mathrm{Si}_{2}$ & 13.117 & 375 \\
\hline 14 & $\mathrm{U}_{3} \mathrm{Si}$ & 13.078 & 375 & 356 & $\mathrm{U}_{3} \mathrm{Si}_{2}$ & 13.175 & 325 \\
\hline 15 & $\mathrm{U}_{3} \mathrm{Si}_{2}$ & 12.918 & 426 & 403 & $\mathrm{UAl}_{\mathrm{x}}$ & 13.264 & 250 \\
\hline 16 & $\mathrm{U}_{3} \mathrm{Si}_{2}$ & 12.941 & 376 & 356 & $\mathrm{U}_{3} \mathrm{Si}_{2}$ & 13.223 & 250 \\
\hline 17 & $\mathrm{U}_{3} \mathrm{Si}_{2}$ & 12.951 & 323 & 303 & $\mathrm{UAl}_{\mathrm{x}}$ & 12.619 & 425 \\
\hline 18 & $\mathrm{U}_{3} \mathrm{Si}_{2}$ & 13.010 & 249 & 230 & $\mathrm{U}_{3} \mathrm{Si}_{2}$ & 12.263 & 425 \\
\hline
\end{tabular}


Table 2.2. Density and composition of fuel particles irradiated in HANS-1 and HANS-2

\begin{tabular}{ccccccc} 
& \multirow{2}{*}{$\begin{array}{c}\text { Fuel } \\
\text { type }\end{array}$} & $\begin{array}{c}\text { Fuel } \\
\text { density } \\
\left(\mathrm{Mg} / \mathrm{m}^{3}\right)\end{array}$ & $\begin{array}{c}\text { Uranium } \\
\text { content } \\
\text { (wt \%) }\end{array}$ & \multicolumn{4}{c}{$\begin{array}{c}\text { Uranium isotopic abundances } \\
\text { (wt \%) }\end{array}$} \\
\hline $\mathrm{UAl}_{\mathrm{x} n}$ & 6.35 & 70.57 & 1.019 & 93.057 & 0.402 & 5.522 \\
$\mathrm{UAl}_{2}$ & 8.06 & 80.87 & 0.556 & 93.048 & 0.426 & 5.971 \\
$\mathrm{U}_{3} \mathrm{O}_{8}$ & 8.20 & 84.67 & 1.010 & 93.164 & 0.389 & 5.437 \\
$\mathrm{U}_{3} \mathrm{Si}_{2}$ & 12.07 & 92.32 & 1.059 & 92.951 & 0.242 & 5.748 \\
$\mathrm{U}_{3} \mathrm{Si}$ & 15.13 & 95.41 & 1.054 & 92.625 & 0.242 & 6.079 \\
\hline
\end{tabular}

In addition to the $\mathrm{SiC}$ monitors, melt monitors were placed in five of the fuel holders in the HANS-2 capsule. These melt monitors consisted of powders of pure metals or eutectics seal-welded into small stainless steel canisters and placed in the fuel holders in a hole concentric with the fuel specimens. Three monitors were placed in the hole in each of the five holders, as shown in Table 2.5. The evaluation of these melt monitors was to be simply to determine by either radiography or metallography which of the powders had melted during the test operation. 
Table 2.3. Fuel loading data for the HANS-1 capsule

\begin{tabular}{|c|c|c|c|c|c|c|c|}
\hline Position & $\begin{array}{l}\text { Fuel } \\
\text { type }\end{array}$ & $\begin{array}{l}\text { Weight of fuel } \\
\text { in hole A } \\
\text { (mg) }\end{array}$ & $\begin{array}{c}\text { Weight of fuel } \\
\text { in hole B } \\
\text { (mg) }\end{array}$ & $\begin{array}{c}\text { Number of } \\
\text { particles in } \\
\text { hole A }\end{array}$ & $\begin{array}{c}\text { Number of } \\
\text { particles in } \\
\text { hole B }\end{array}$ & $\begin{array}{l}\text { Average diameter of } \\
\text { particles in hole } \mathrm{A}^{a} \\
(\mu \mathrm{m})\end{array}$ & $\begin{array}{c}\text { Average diameter of } \\
\text { particles in hole } B^{a} \\
(\mu \mathrm{m})\end{array}$ \\
\hline 1 & $\mathrm{U}_{3} \mathrm{Si}_{2}$ & 0.23 & 0.21 & 28 & 33 & 88 & 81 \\
\hline 2 & $\mathrm{U}_{3} \mathrm{Si}_{2}$ & 0.36 & 0.31 & 41 & 40 & 90 & 86 \\
\hline 3 & $\mathrm{U}_{3} \mathrm{Si}_{2}$ & 0.28 & 0.33 & 40 & 38 & 83 & 90 \\
\hline 4 & $\mathrm{U}_{3} \mathrm{Si}_{2}$ & 0.29 & 0.29 & 36 & 37 & 87 & 87 \\
\hline 5 & $\mathrm{U}_{3} \mathrm{Si}$ & 0.26 & 0.26 & 22 & 35 & 92 & 79 \\
\hline 6 & $\mathrm{U}_{3} \mathrm{Si}_{2}$ & 0.31 & 0.3 & 38 & 35 & 88 & 89 \\
\hline 7 & $\mathrm{U}_{3} \mathrm{Si}_{2}$ & 0.26 & 0.27 & 33 & 37 & 87 & 85 \\
\hline 8 & $\mathrm{U}_{3} \mathrm{Si}_{2}$ & 0.32 & 0.28 & 33 & 31 & 93 & 91 \\
\hline 9 & $\mathrm{U}_{3} \mathrm{Si}_{2}$ & 0.26 & 0.33 & 43 & 28 & 79 & 99 \\
\hline 10 & $\mathrm{U}_{3} \mathrm{Si}_{2}$ & 0.3 & 0.3 & 29 & 29 & 95 & 95 \\
\hline 11 & $\mathrm{U}_{3} \mathrm{Si}_{2}$ & 0.29 & 0.3 & 30 & 24 & 93 & 101 \\
\hline 12 & $\mathrm{U}_{3} \mathrm{Si}_{2}$ & 0.32 & 0.27 & 27 & 33 & 99 & 88 \\
\hline 13 & $\mathrm{U}_{3} \mathrm{Si}_{2}$ & 0.28 & 0.28 & 43 & 26 & 81 & 96 \\
\hline 14 & $\mathrm{U}_{3} \mathrm{Si}$ & 0.26 & 0.27 & 35 & 28 & 79 & 86 \\
\hline 15 & $\mathrm{U}_{3} \mathrm{Si}_{2}$ & 0.25 & 0.28 & 32 & 33 & 87 & 89 \\
\hline 16 & $\mathrm{U}_{3} \mathrm{Si}_{2}$ & 0.3 & 0.28 & 30 & 33 & 94 & 89 \\
\hline 17 & $\mathrm{U}_{3} \mathrm{Si}_{2}$ & 0.29 & 0.28 & 33 & 34 & 90 & 88 \\
\hline 18 & $\mathrm{U}_{3} \mathrm{Si}_{2}$ & 0.26 & 0.32 & 25 & 35 & 95 & 91 \\
\hline
\end{tabular}

aParticles are assumed to be spherical. 
Table 2.4. Fuel loading data for the HANS-2 capsule

\begin{tabular}{|c|c|c|c|c|c|c|c|}
\hline Position & $\begin{array}{l}\text { Fuel } \\
\text { type }\end{array}$ & $\begin{array}{l}\text { Weight of fuel } \\
\text { in hole A } \\
\text { (mg) }\end{array}$ & $\begin{array}{l}\text { Weight of fuel } \\
\text { in hole B } \\
\text { (mg) }\end{array}$ & $\begin{array}{l}\text { Number of } \\
\text { particles in } \\
\text { hole A }\end{array}$ & $\begin{array}{c}\text { Number of } \\
\text { particles in } \\
\text { hole B }\end{array}$ & $\begin{array}{c}\text { Average diameter of } \\
\text { particles in hole } \mathrm{A}^{a} \\
(\mu \mathrm{m})\end{array}$ & $\begin{array}{l}\text { Average diameter of } \\
\text { particles in hole } B^{a} \\
(\mu \mathrm{m})\end{array}$ \\
\hline 1 & $\mathrm{U}_{3} \mathrm{O}_{8}$ & 0.26 & 0.29 & $>60$ & $>60$ & $<81$ & $<84$ \\
\hline 2 & $\mathrm{UAl}_{2}$ & 0.34 & 0.27 & 46 & 29 & 97 & 105 \\
\hline 3 & $\mathrm{U}_{3} \mathrm{O}_{8}$ & 0.3 & 0.3 & $>60$ & $>60$ & $<85$ & $<85$ \\
\hline 4 & $\mathrm{UAl}_{2}$ & 0.32 & 0.33 & 52 & 46 & 91 & 96 \\
\hline 5 & $\mathrm{U}_{3} \mathrm{O}_{8}$ & 0.31 & 0.29 & $>60$ & $>60$ & $<86$ & $<84$ \\
\hline 6 & $\mathrm{UAl}_{2}$ & 0.35 & 0.29 & 45 & 43 & 99 & 94 \\
\hline 7 & $\mathrm{U}_{3} \mathrm{O}_{8}$ & 0.31 & 0.31 & $>60$ & $>60$ & $<86$ & $<86$ \\
\hline 8 & $\mathrm{UAl}_{2}$ & 0.32 & 0.3 & 45 & 46 & 96 & 93 \\
\hline 9 & $\mathrm{U}_{3} \mathrm{O}_{8}$ & 0.3 & 0.27 & $>60$ & $>60$ & $<85$ & $<82$ \\
\hline 10 & $\mathrm{UAl}_{\mathrm{x}}$ & 0.34 & 0.38 & $>60$ & $>60$ & $<96$ & $<100$ \\
\hline 11 & $\mathrm{U}_{3} \mathrm{Si}_{2}$ & 0.28 & 0.29 & 30 & 29 & 92 & 94 \\
\hline 12 & $\mathrm{UAl}_{\mathrm{x}}$ & 0.34 & 0.34 & $>60$ & $>60$ & $<96$ & $<96$ \\
\hline 13 & $\mathrm{U}_{3} \mathrm{Si}_{2}$ & 0.26 & 0.32 & 33 & 32 & 87 & 94 \\
\hline 14 & $\mathrm{U}_{3} \mathrm{Si}_{2}$ & 0.31 & 0.28 & 30 & 27 & 95 & 95 \\
\hline 15 & $\mathrm{UAl}_{x}$ & 0.37 & 0.38 & $>60$ & $>60$ & $<99$ & $<100$ \\
\hline 16 & $\mathrm{U}_{3} \mathrm{Si}_{2}$ & 0.26 & 0.26 & 27 & 30 & 93 & 90 \\
\hline 17 & $\mathrm{UAl}_{\mathrm{x}}$ & 0.37 & 0.38 & $>60$ & $>60$ & $<99$ & $<100$ \\
\hline 18 & $\mathrm{U}_{3} \mathrm{Si}_{2}$ & 0.25 & 0.28 & 29 & 28 & 89 & 94 \\
\hline
\end{tabular}

${ }^{a}$ Particles are assumed to be spherical. 


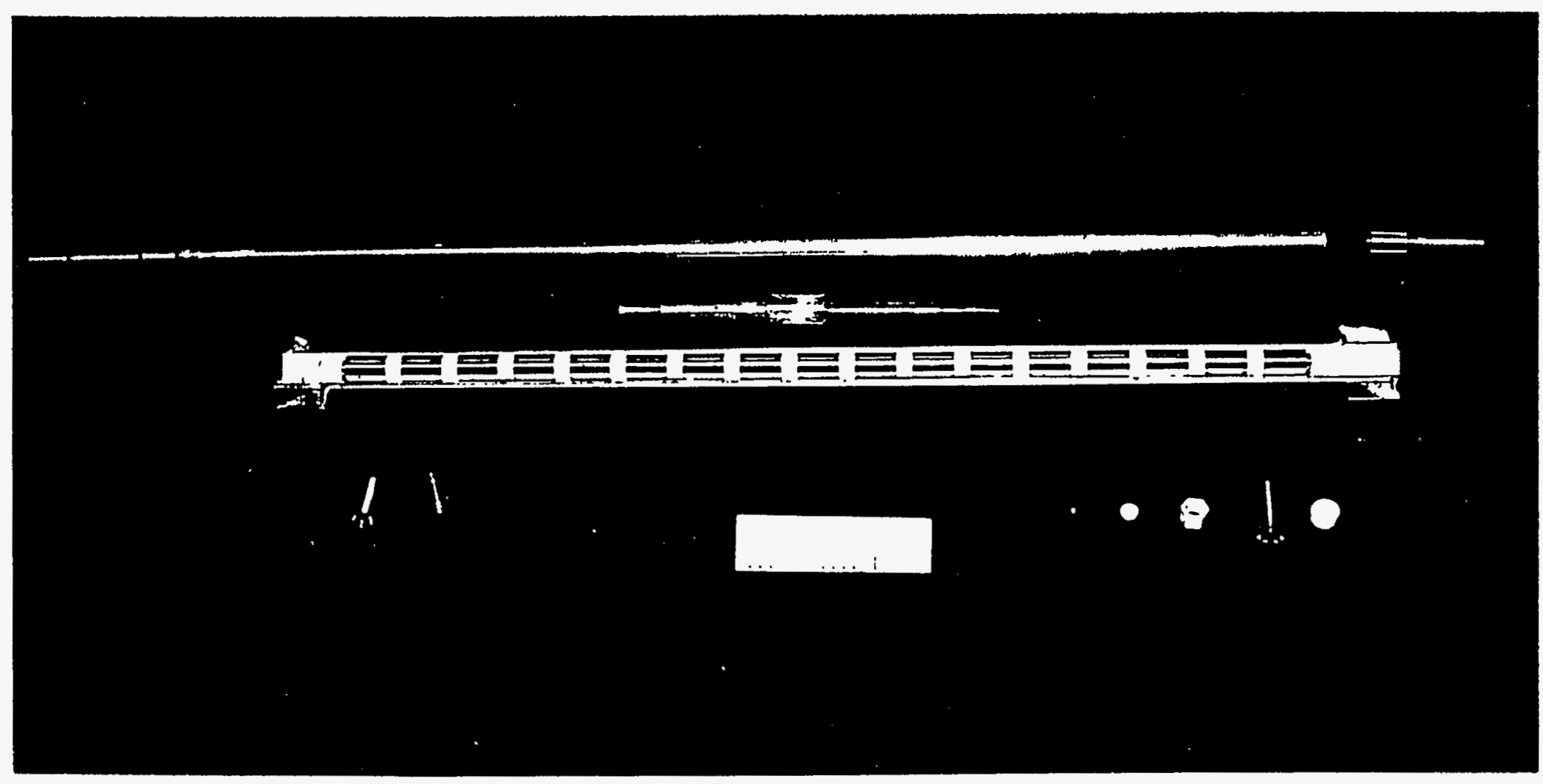




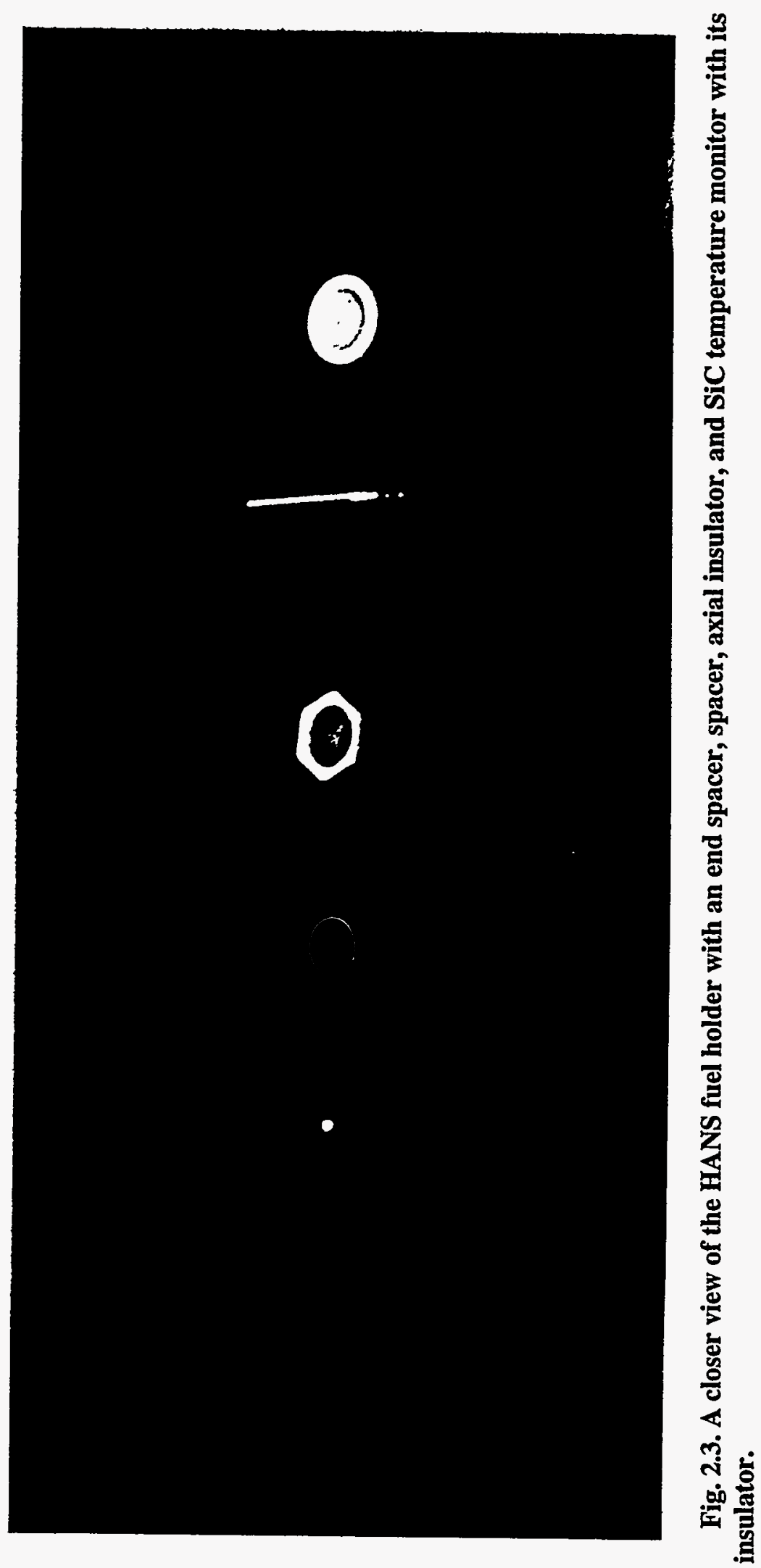


Table 2.5. Melt monitors used in the HANS-2 experiment

\begin{tabular}{lcccccc}
\hline \multirow{2}{*}{ Monitor material } & $\begin{array}{c}\text { Melting temperature } \\
\left({ }^{\circ} \mathrm{C}\right)\end{array}$ & \multicolumn{5}{c}{ Monitors in holder at position number } \\
\cline { 3 - 6 } & 232 & & $\mathrm{X}$ & & & \\
\hline $\mathrm{Sn}$ & 247 & & $\mathrm{X}$ & $\mathrm{X}$ & & \\
$\mathrm{Pb}-\mathrm{Sn}$ & 271 & $\mathrm{X}$ & $\mathrm{X}$ & $\mathrm{X}$ & $\mathrm{X}$ & $\mathrm{X}$ \\
$\mathrm{Bi}$ & 327 & $\mathrm{X}$ & & $\mathrm{X}$ & $\mathrm{X}$ & $\mathrm{X}$ \\
$\mathrm{Pb}$ & 420 & $\mathrm{X}$ & & & $\mathrm{X}$ & $\mathrm{X}$ \\
$\mathrm{Zn}$ & & & & & & \\
\hline
\end{tabular}




\section{IRRADIATION}

The HANS-1 capsule was irradiated in position F7 of the HFIR target region during cycle 289, which began on June 26, 1990, and ended on September 7, 1990, with an integrated reactor power of $1881 \mathrm{MWd}$. This was the first cycle following a several-year shutdown of HFIR, and only $17 \%$ of the integrated power was accumulated before August 20. The nominal reactor power was $85 \mathrm{MW}$; however, the first $1.6 \mathrm{~h}$ of operation was at $8.5 \mathrm{MW}$.

The HANS-2 capsule was irradiated in position F7 of the HFIR target region during cycle 315, which began on January 19, 1993, and ended on February 10, 1993, with an integrated reactor power of $1861 \mathrm{MWd}$. The nominal reactor power was $85 \mathrm{MW}$.

Depletion of ${ }^{235} U$ and fission densities in the fuel particles at the end of the irradiations were calculated using one-group ${ }^{11}$ and two-group fluxes and cross sections for the target region. The calculated initial fission rates, final ${ }^{235} \mathrm{U}$ burnups, and final fission densities in the fuel particles of the various fuel holders are given in Table 3.1. These values are based on the average reaction rates derived from the one-group and two-group fluxes, assuming that the flux in the target region remained constant during the irradiation. As a point of reference, based on a conversion factor of $3.1 \times 10^{10}$ fissions $\mathrm{W}^{-1} \cdot \mathrm{s}^{-1}$, the initial fission rate in the fuel particles in holders 9 and 10 of the HANS-1 capsule is $916 \mathrm{MW} / \mathrm{L}$. 
Table 3.1. Initial fission rate and final burnup and fission density in the fuel particles

\begin{tabular}{|c|c|c|c|c|c|c|}
\hline \multirow[b]{2}{*}{$\begin{array}{l}\text { Position } \\
\text { number }\end{array}$} & \multicolumn{3}{|c|}{ HANS-1 Capsule } & \multicolumn{3}{|c|}{ HANS-2 Capsule } \\
\hline & $\begin{array}{c}\text { Initial } \\
\text { fission rate } \\
\left(10^{22} \mathrm{~m}^{-3} \cdot \mathrm{s}^{-1}\right)\end{array}$ & $\begin{array}{l}\text { Final } \\
{ }^{235} \text { U burnup } \\
(\%)\end{array}$ & $\begin{array}{c}\text { Final fission } \\
\text { density in } \\
\text { particle } \\
\left(10^{27} \mathrm{~m}^{-3}\right) \\
\end{array}$ & $\begin{array}{c}\text { Initial } \\
\text { fission rate } \\
\left(10^{22} \mathrm{~m}^{-3} \cdot \mathrm{s}^{-1}\right)\end{array}$ & $\begin{array}{l}\text { Final } \\
{ }^{235} \mathrm{U} \text { burnup } \\
\text { (\%) }\end{array}$ & $\begin{array}{c}\text { Final fission } \\
\text { density in } \\
\text { particle } \\
\left(10^{27} \mathrm{~m}^{-3}\right) \\
\end{array}$ \\
\hline 1 & 1.56 & 72.6 & 16.4 & 0.97 & 72.2 & 10.2 \\
\hline 2 & 1.80 & 77.4 & 17.5 & 1.05 & 77.1 & 10.2 \\
\hline 3 & 2.03 & 81.3 & 18.4 & 1.27 & 81.0 & 11.4 \\
\hline 4 & 2.25 & 84.4 & 19.1 & 1.32 & 84.1 & 11.1 \\
\hline 5 & 3.14 & 86.7 & 25.3 & 1.52 & 86.4 & 12.2 \\
\hline 6 & 2.59 & 88.4 & 20.0 & 1.52 & 88.2 & 11.7 \\
\hline 7 & 2.72 & 89.6 & 20.3 & 1.70 & 89.3 & 12.6 \\
\hline 8 & 2.80 & 90.3 & 20.4 & 1.64 & 90.1 & 11.9 \\
\hline 9 & 2.84 & 90.6 & 20.5 & 1.77 & 90.4 & 12.8 \\
\hline 10 & 2.84 & 90.6 & 20.5 & 1.14 & 90.4 & 8.2 \\
\hline 11 & 2.80 & 90.3 & 20.4 & 2.80 & 90.1 & 20.4 \\
\hline 12 & 2.72 & 89.6 & 20.3 & 1.09 & 89.3 & 8.1 \\
\hline 13 & 2.59 & 88.4 & 20.0 & 2.59 & 88.1 & 19.9 \\
\hline 14 & 3.14 & 86.7 & 25.3 & 2.44 & 86.4 & 19.5 \\
\hline 15 & 2.25 & 84.4 & 19.1 & 0.90 & 84.1 & 7.7 \\
\hline 16 & 2.03 & 81.3 & 18.4 & 2.03 & 81.0 & 18.3 \\
\hline 17 & 1.80 & 77.4 & 17.5 & 0.72 & 77.0 & 7.0 \\
\hline 18 & 1.56 & 72.6 & 16.4 & 1.56 & 72.2 & 16.3 \\
\hline
\end{tabular}




\section{POSTIRRADIATION EXAMINATIONS}

\subsection{DISASSEMBLY}

The capsules were disassembled in the Irradiated Fuels Examination Laboratory at Oak Ridge National Laboratory (ORNL). The capsules were examined visually for evidence of damage. No evidence of bowing, swelling, or cracking was observed for either capsule. For the HANS-1 capsule, the first attempt to remove the fuel holders (by cutting the end fittings from the tube and pushing the holders and spacers out) was unsuccessful because of swelling of the spacers. The individual fuel holders were eventually removed by placing the tube in a lathe and cutting through the tube at about the midpoint of each fuel holder. The fuel holders could then be separated from the spacers. In the attempt to disassemble the HANS-2 capsule by cutting off the end caps and slitting through the outer capsule on two sides, the milling machine failed after about half of one cut. Again, each holder was cut out with the lathe in the same manner as for HANS-1.

The spacers and insulators were examined during the disassembly of HANS-1. The spacers and insulators performed satisfactorily although they underwent some swelling and cracking during the test. They did not deform the outer capsule tube and held everything in place (even during attempts at disassembly). After removing the Mycalex spacers from near the ends of the capsule (fuel holders 16 and 17), dimensional measurements could be made on some of the parts. The Macor insulator from holder 17 grew in thickness from 2.56 to $2.90 \mathrm{~mm}$ and in diameter from 8.64-8.66 to $8.97-8.99 \mathrm{~mm}$. The Mycalex spacer from this region grew in thickness from 7.87 to $7.90 \mathrm{~mm}$ to $8.18 \mathrm{~mm}$. The diameters of the spacers could not be measured because of breakage upon removal. The capsule tubing apparently restrained the radial growth of the spacers at the hexagonal points of contact, and the points rounded somewhat, as shown in Fig. 4.1. This photograph also shows the apparent extrusion of Mycalex material in between the Macor insulator and the fuel holder. The spacers showed some cracking before removal from the tubing, as shown in Fig. 4.2. Most broke into fragments upon removal, as shown in Fig. 4.3. The disk-shaped Macor insulators (also shown in Fig. 4.3) tended to remain intact near the ends of the capsule. However, near the center of the capsule where the fluence was higher, there were some indications that the Macor insulators had extruded into the hexagonal wrench socket of the stainless steel set screws in the bottoms of the fuel holders. It was decided to continue the use of these materials in future HANS capsules because they did serve their purpose of maintaining the fuel holders centered in the capsule, they did not harm the capsule or holders, and they have low thermal conductivity. The alumina insulators separating the $\mathrm{SiC}$ temperature monitors from the steel set screw remained in one piece, but they were not measured.

The $\mathrm{SiC}$ temperature monitors were quite difficult to remove from some of the fuel holders because of difficulty in removing the stainless steel set screws from the aluminum holders. The steel screws appeared to be tight or galled even though they were very loose when assembled. About half of the set screws in HANS-1 had to be removed by machining away the aluminum in the lathe. Some of the screws near the center also had the wrench sockets filled with material apparently from the Macor insulators. In HANS-2, the monitors that could not be removed simply by backing out the set screw were not removed.

\subsection{EVALUATION OF TEMPERATURE MONTORS}

The SiC temperature monitors were evaluated for each capsule by sequential annealing, followed by precision length measurements at room temperature. The results were mixed. Some of the monitors showed classic behavior with very little scatter in the data and a distinct point, identifiable within a few 


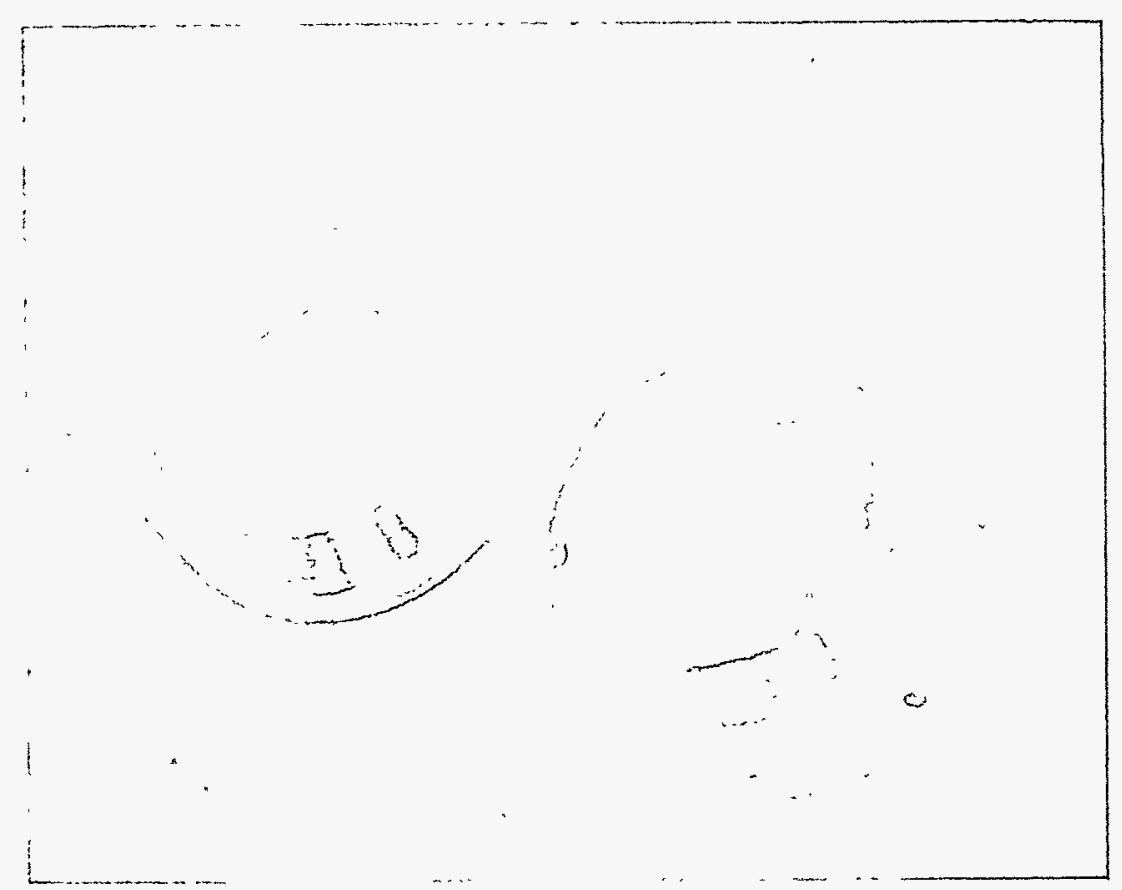

Fig. 4.1. A section of the HANS-1 capsule tube from holder 18 and a section from holder 16 containing a Mycalex spacer and a Macor insulator.

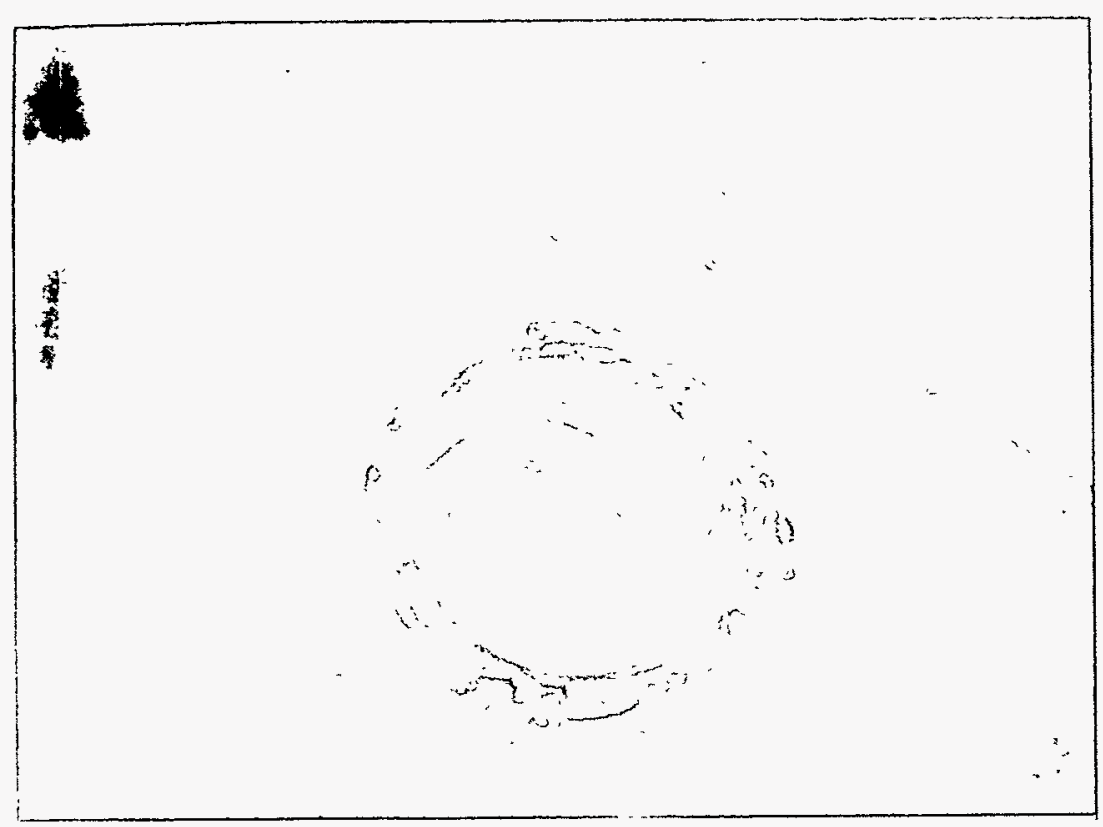

Fig. 4.2. Spacer and insulator from holder 18 showing cracks in Mycalex spacer before attempt to remove from tubing of the HANS-1 experiment. 


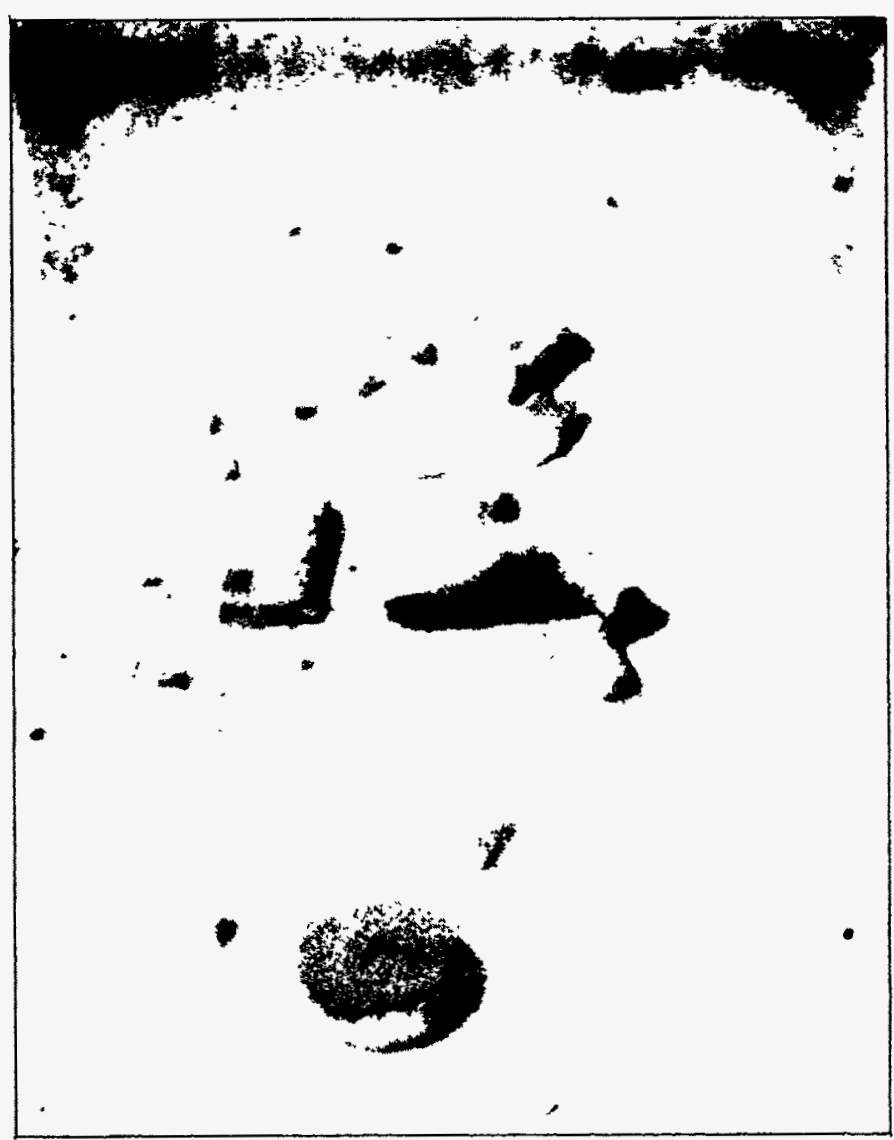

Fig. 4.3. Crumbled Mycalex spacer and Macor insulator (disk) from holder 17 of the HANS-1 experiment.

degrees, that could be judged to be the irradiation temperature. Other monitors showed erratic behavior with either a lot of scatter in the data or no sharply defined slope change. Some examples of length vs annealing temperature curves are shown in Figs. 4.4 through 4.6.

For the HANS-2 capsule, the melt monitors were evaluated by examining the monitors metallographically to determine if the powders had melted during the irradiation. When allowance is made for about $50^{\circ} \mathrm{C}$ additional temperature in the melt wire capsules because of $\gamma$ heating in them combined with the poor thermal conductivity of the powders, the melt monitor results are consistent with the design temperatures.

- Table 4.1 presents the design temperatures of the fuel holders, along with an interpretation of data from the annealing of the $\mathrm{SiC}$ monitors and the results of the melt monitor evaluation. The conclusion from these data is that the best examples of the $\mathrm{SiC}$ evaluations tend to agree reasonably well with the design temperatures. Considering the apparent inaccuracy of many of the monitors, the design temperatures are thought to represent as good a measure of the actual temperature during irradiation as is available. During subsequent discussions; the design temperatures will be quoted as the irradiation temperature. For all practical purposes, the specimens may be considered to have been irradiated at high $\left(300\right.$ to $\left.450^{\circ} \mathrm{C}\right)$ or low $\left(<300^{\circ} \mathrm{C}\right)$ temperatures. 


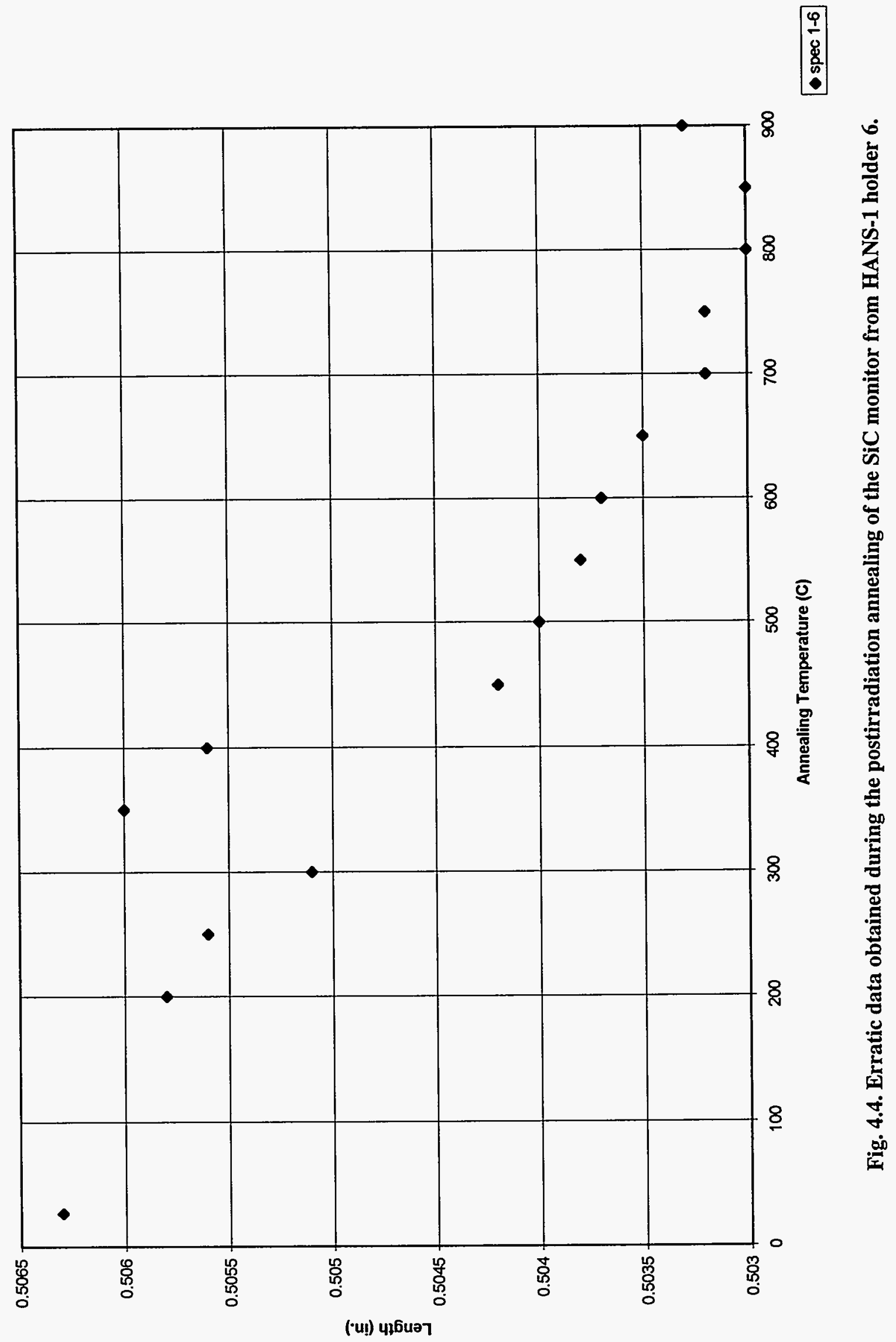




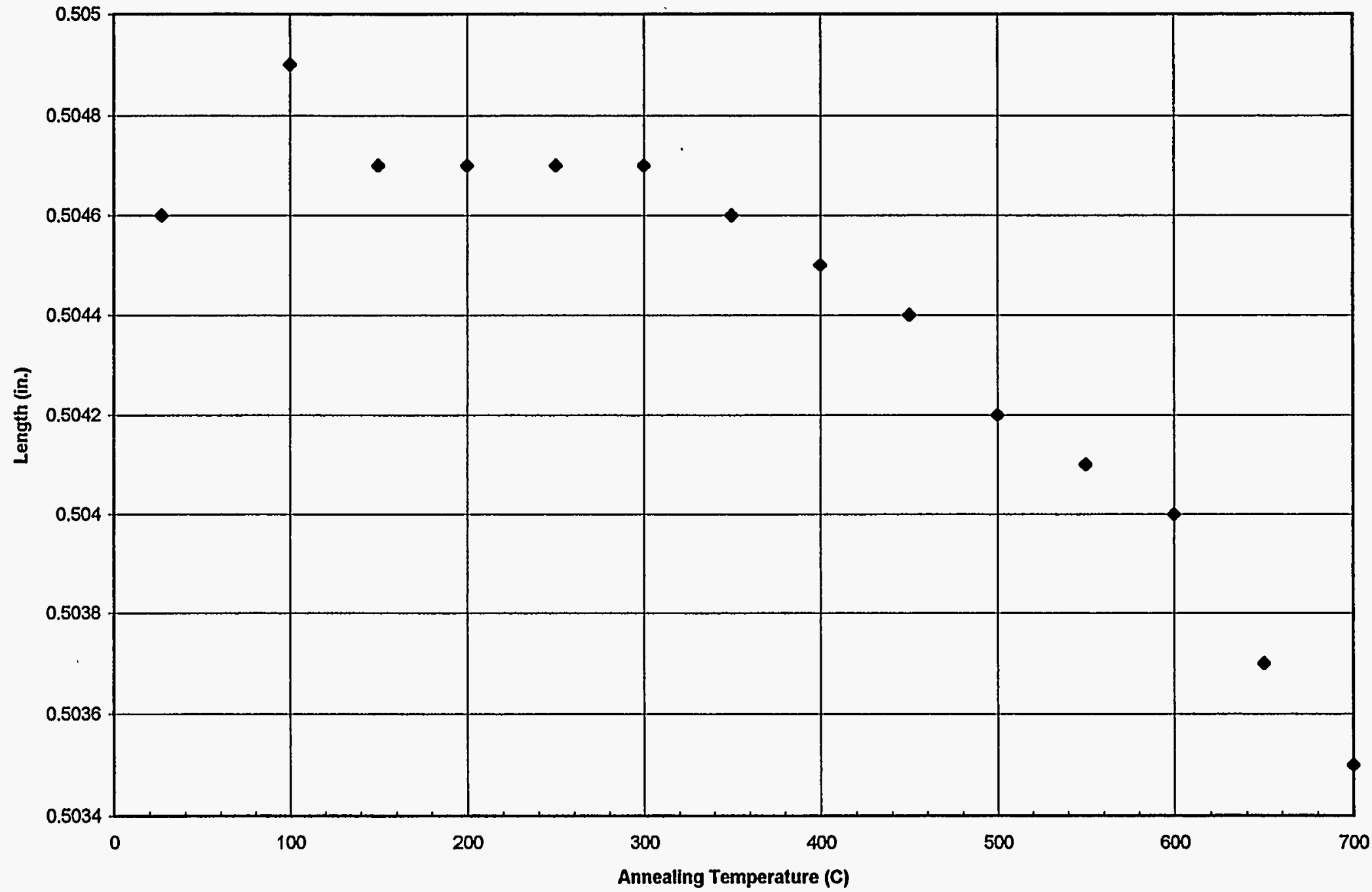

Fig. 4.5. Good data obtained during the postirradiation annealing of the SiC monitor from HANS-1 holder 14. 


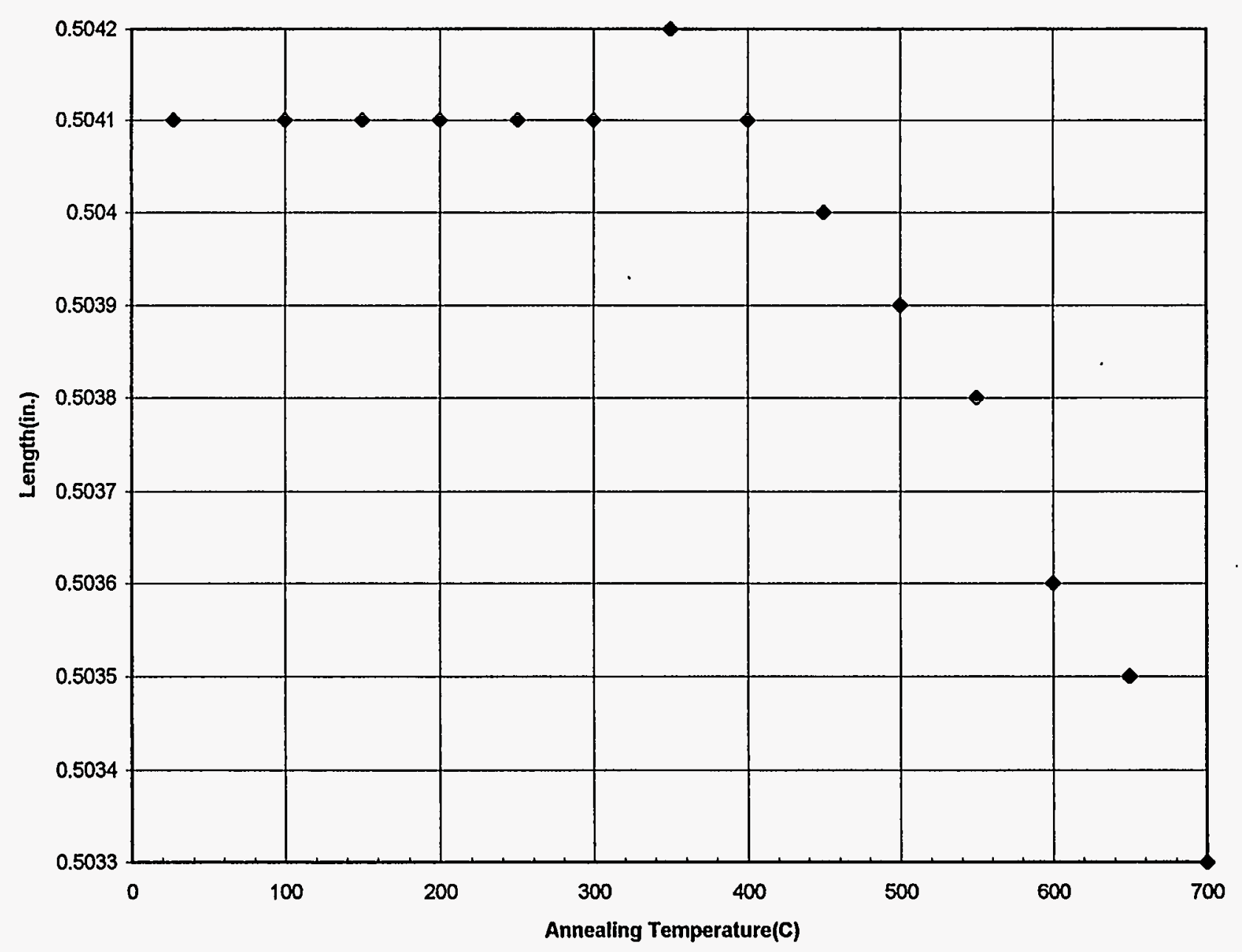

Fig. 4.6. Good data obtained during the postirradiation annealing of the SiC monitor from HANS-2 holder 1. 
Table 4.1. Temperature monitor evaluation for HANS-1 and HANS-2

\begin{tabular}{|c|c|c|c|c|c|}
\hline \multirow[b]{2}{*}{$\begin{array}{l}\text { Fuel holder } \\
\text { number }\end{array}$} & \multicolumn{2}{|c|}{ HANS-1 } & \multicolumn{3}{|c|}{ HANS-2 } \\
\hline & $\begin{array}{c}\text { Design } \\
\text { temperature } \\
\left({ }^{\circ} \mathrm{C}\right) \\
\end{array}$ & $\begin{array}{l}\text { SiC monitor } \\
\text { temperature } \\
\left({ }^{\circ} \mathrm{C}\right)\end{array}$ & $\begin{array}{c}\text { Design } \\
\text { temperature } \\
\left({ }^{\circ} \mathrm{C}\right) \\
\end{array}$ & $\begin{array}{c}\text { SiC monitor } \\
\text { temperature } \\
\left({ }^{\circ} \mathrm{C}\right)\end{array}$ & $\begin{array}{l}\text { Melt monitor } \\
\text { evaluation } \\
\left({ }^{\circ} \mathrm{C}\right)\end{array}$ \\
\hline 1 & 425 & & 425 & $400^{a}$ & \\
\hline 2 & 375 & 300 & 425 & 370 & $327-420$ \\
\hline 3 & 325 & 310 & 250 & 200 & \\
\hline 4 & 250 & 350 & 250 & $200^{a}$ & 2271 \\
\hline 5 & $<250$ & 170 & 325 & $300_{a}$ & 2327 \\
\hline 6 & 250 & 200 & 375 & $280^{a}$ & \\
\hline 7 & 325 & 290 & 375 & & $327-420$ \\
\hline 8 & 375 & 325 & 425 & & \\
\hline 9 & 425 & $280^{a}$ & 425 & & \\
\hline 10 & 425 & 200 & 425 & & \\
\hline 11 & 375 & $225^{a}$ & 425 & & \\
\hline 12 & 325 & 275 & 375 & 200 & \\
\hline 13 & 250 & 240 & 375 & & \\
\hline 14 & 375 & $450^{\circ}$ & 325 & $300^{a}$ & \\
\hline 15 & 425 & $435^{a}$ & 250 & $285^{a}$ & \\
\hline 16 & 375 & 300 & 250 & $250^{a}$ & \\
\hline 17 & 325 & 315 & 425 & & \\
\hline 18 & 250 & $200^{a}$ & 425 & & \\
\hline
\end{tabular}

andicates better-looking curves.

\subsection{BURNUP MEASUREMENTS}

Mass spectrographic measurements of the uranium isotopic abundances in the burned fuel were performed on one of the fuel zones in HANS-1 samples 10 and 17 after dissolution of the fuel samples. The samples were submitted on July 1,1992 . Because of administrative restrictions in effect at ORNL at that time, there were long delays between processing steps. The actual mass spectrographic measurements were performed in late September or early October 1994. The results are shown in Table 4.2.

The ${ }^{235} \mathrm{U}$ burnup (depletion) of each sample was determined using the following relationship:

$$
B=\frac{1-A / A_{0}}{1-(1+C+D+E) A},
$$

where

$B=$ fractional ${ }^{235} \mathrm{U}$ depletion,

$A_{0}=$ fractional ${ }^{235} \mathrm{U}$ atomic abundance in fresh fuel,

$A=$ fractional ${ }^{235} \mathrm{U}$ atomic abundance in bumed fuel,

$C={ }^{238} \mathrm{U} /{ }^{235} \mathrm{U}$ atomic depletion ratio during irradiation, 
Table 4.2. Burnup Evaluation for HANS-1 holders 10 and 17

\begin{tabular}{lll} 
& Holder 10 & Holder 17 \\
\hline Final ${ }^{234} \mathrm{U}$ abundance, at. \% & 2.01 & 2.23 \\
Final ${ }^{235} \mathrm{U}$ abundance, at. \% & 48.6 & 44.30 \\
Final ${ }^{236} \mathrm{U}$ abundance, at. \% & 29.72 & 36.21 \\
Final ${ }^{238} \mathrm{U}$ abundance, at. \% & 19.67 & 17.26 \\
${ }^{238} \mathrm{U} /{ }^{35} \mathrm{U}$ atomic depletion ratio & 0.00626 & 0.00415 \\
${ }^{236} \mathrm{U} /{ }^{235} \mathrm{U}$ atomic depletion ratio & -0.1442 & -0.1475 \\
${ }^{234} \mathrm{U} /{ }^{335} \mathrm{U}$ atomic depletion ratio & 0.00437 & 0.00344 \\
"Measured" burnup, \% & 82.5 & 84.6 \\
Calculated burnup, \% & 90.6 & 77.4 \\
\hline
\end{tabular}

$D={ }^{236} \mathrm{U} /{ }^{35} \mathrm{U}$ atomic depletion ratio during irradiation,

$E={ }^{234} \mathrm{U} /{ }^{35} \mathrm{U}$ atomic depletion ratio during irradiation.

The parameters $C, D$, and $E$ were derived from the reaction rate calculations discussed in Sect. 3. These parameters and the burnups derived from the reaction rate calculations are also tabulated in Table 4.2 along with the "measured" burnups. The burnups based on the mass spectrographic data are very similar to each other, differ from the calculated burnups by $\sim 9 \%$, and show an opposite burnup profile than would actually result from the axial flux profile of the reactor. Because there is no way that the actual burnup distribution could be reversed, either the samples were misidentified, or the measurements were inaccurate. Since it is highly unlikely that the samples were misidentified, perhaps the chemical dissolutions were not complete. Nevertheless, the high measured burnups do confirm that the samples reached burnups in the predicted range. Since no further data have been obtained, it has been assumed that the burnups based on calculated reaction rates are correct.

\subsection{MICROSTRUCTURAL EXAMINATIONS}

The microstructural examinations performed on the HANS-1 and HANS-2 samples are listed in Table 4.3. The results are discussed in the following section. In addition to the micrographs discussed and included in the text, more are in Appendix B. Negatives for most of these micrographs and others are on file at either ORNL or ANL.

\subsection{DISCUSSION OF RESULTS}

\subsection{1 $\mathrm{U}_{3} \mathrm{Si}_{2}$-AI Interaction}

Interaction between a fuel particle and the surrounding aluminum matrix during irradiation consists essentially of three items:

1. hardening of a thin shell of $\mathrm{Al}$ directly adjacent to the fuel particle surface, caused by fission fragment recoil damage, 
Table 4.3. Microstructural examinations performed

\begin{tabular}{|c|c|c|c|c|c|c|c|}
\hline \multirow[b]{2}{*}{ Position } & \multicolumn{4}{|c|}{ HANS- 1 capsule } & \multicolumn{3}{|c|}{ HANS-2 capsule } \\
\hline & $\begin{array}{l}\text { Fuel } \\
\text { type }\end{array}$ & $\begin{array}{c}\text { Optical } \\
\text { metallography }\end{array}$ & $\begin{array}{l}\text { Scanning } \\
\text { electron } \\
\text { microscopy }\end{array}$ & $\begin{array}{c}\text { Electron } \\
\text { microprobe } \\
\text { microscopy }\end{array}$ & $\begin{array}{l}\text { Fuel } \\
\text { type }\end{array}$ & $\begin{array}{c}\text { Optical } \\
\text { metallography }\end{array}$ & $\begin{array}{c}\text { Scanning } \\
\text { electron } \\
\text { microscopy }\end{array}$ \\
\hline 1 & $\mathrm{U}_{3} \mathrm{Si}_{2}$ & & & & $\mathrm{U}_{3} \mathrm{O}_{8}$ & $\mathrm{x}$ & $\mathrm{x}$ \\
\hline 2 & $\mathrm{U}_{3} \mathrm{Si}_{2}$ & $\mathrm{x}$ & $\mathrm{x}$ & & $\mathrm{UAl}_{2}$ & & \\
\hline 3 & $\mathrm{U}_{3} \mathrm{Si}_{2}$ & $\mathrm{X}$ & $\mathrm{X}$ & & $\mathrm{U}_{3} \mathrm{O}_{8}$ & $\mathrm{X}$ & \\
\hline 4 & $\mathrm{U}_{3} \mathrm{Si}_{2}$ & $\mathrm{X}$ & $\mathrm{x}$ & & $\mathrm{UAl}_{2}$ & $\mathrm{x}$ & \\
\hline 5 & $\mathrm{U}_{3} \mathrm{Si}$ & $\mathrm{x}$ & & & $\mathrm{U}_{3} \mathrm{O}_{8}$ & & \\
\hline 6 & $\mathrm{U}_{3} \mathrm{Si}_{2}$ & $\mathrm{x}$ & & & $\mathrm{UAl}_{2}$ & $\mathrm{x}$ & \\
\hline 7 & $\mathrm{U}_{3} \mathrm{Si}_{2}$ & $\mathrm{x}$ & & & $\mathrm{U}_{3} \mathrm{O}_{8}$ & & \\
\hline 8 & $\mathrm{U}_{3} \mathrm{Si}_{2}$ & $\mathrm{x}$ & & & $\mathrm{UAl}_{2}$ & $\mathrm{x}$ & \\
\hline 9 & $\mathrm{U}_{3} \mathrm{Si}_{2}$ & & & & $\mathrm{U}_{3} \mathrm{O}_{8}$ & & \\
\hline 10 & $\mathrm{U}_{3} \mathrm{Si}_{2}$ & $\mathrm{x}$ & $\mathrm{x}$ & & $\mathrm{UAl}_{\mathrm{x}}$ & $\mathrm{x}$ & $\mathrm{x}$ \\
\hline 11 & $\mathrm{U}_{3} \mathrm{Si}_{2}$ & $\mathrm{x}$ & & & $\mathrm{U}_{3} \mathrm{Si}_{2}$ & $\mathrm{x}$ & \\
\hline 12 & $\mathrm{U}_{3} \mathrm{Si}_{2}$ & $\mathrm{x}$ & & & $\mathrm{UAl}_{\mathrm{x}}$ & $\mathrm{x}$ & \\
\hline 13 & $\mathrm{U}_{3} \mathrm{Si}_{2}$ & $\mathrm{x}$ & & & $\mathrm{U}_{3} \mathrm{Si}_{2}$ & $\mathrm{x}$ & \\
\hline 14 & $\mathrm{U}_{3} \mathrm{Si}$ & $\mathrm{x}$ & & & $\mathrm{U}_{3} \mathrm{Si}_{2}$ & $\mathrm{x}$ & \\
\hline 15 & $\mathrm{U}_{3} \mathrm{Si}_{2}$ & $\mathrm{x}$ & & & $\mathrm{UAl}_{\mathrm{x}}$ & $\mathrm{x}$ & $\mathrm{X}$ \\
\hline 16 & $\mathrm{U}_{3} \mathrm{Si}_{2}$ & Serial sections & & & $\mathrm{U}_{3} \mathrm{Si}_{2}$ & $\mathrm{x}$ & \\
\hline 17 & $\mathrm{U}_{3} \mathrm{Si}_{2}$ & $\mathrm{x}$ & $\mathrm{x}$ & $\mathrm{x}$ & $\mathrm{UAl}_{\mathrm{x}}$ & $\mathrm{x}$ & \\
\hline 18 & $\mathrm{U}_{3} \mathrm{Si}_{2}$ & $\mathrm{x}$ & & & $\mathrm{U}_{3} \mathrm{Si}_{2}$ & & \\
\hline
\end{tabular}


2. stress relaxation by plastic flow in the $\mathrm{Al}$ matrix in response to fuel particle swelling, and

3. interdiffusion of $\mathrm{Al}$ and $\mathrm{U}_{3} \mathrm{Si}_{2}$.

At the relatively low temperatures prevailing in existing research reactor fuels, these effects are all essentially athermal, i.e., their kinetics are determined primarily by the fission rate and the neutron flux.

Examples of these effects are shown in Fig. 4.7 for LEU and HEU dispersion fuel irradiated in the ORR, where the maximum temperature of the dispersion (meat) was approximately $100^{\circ} \mathrm{C}$. The room-temperature microhardness of the matrix Al has changed from a preirradiation, fully annealed, value of $35 \mathrm{dph}$ (diamond-pyramid hardness) to $75-80 \mathrm{dph}$ at high burnup. This represents roughly a threefold increase in the yield strength and is in agreement with previous studies of irradiation hardening. ${ }^{12}$ The recoil damage zone, with a width of about $12 \mu \mathrm{m}$, is clearly much harder yet, reaching dph values of 160 to 180 .

Fuel plates are customarily finished with a cold-roll step, leaving the $\mathrm{Al}$ matrix with a preirradiation hardness of 50 to $60 \mathrm{dph}$. It has been shown, however, that at a relatively low neutron exposure $\left(\sim 10^{22} \mathrm{~m}^{-2}\right)$, this cold-worked $\mathrm{Al}$ recovers to the fully annealed state. ${ }^{13}$ Thus, except for this brief initial irradiation period, both cold-worked and annealed Al have similar irradiation damage behavior.

This increase in the strength of the Al matrix does not necessarily imply a greater restraining force on the swelling fuel particle. Swelling data and modeling indicate that fuel-swelling-induced stress relaxation in the Al matrix occurs by creep. Below a temperature one-third the melting point of a material $\left(311 \mathrm{~K}\right.$ or $38^{\circ} \mathrm{C}$ for $\left.\mathrm{Al}\right)$, in-reactor creep is athermal with a linear dependence on applied stress and neutron flux. With increasing temperature, irradiation-enhanced creep diminishes while classical thermally activated creep becomes more important, completely dominating the deformation above a temperature one-half the melting point ( $466 \mathrm{~K}$ or $193^{\circ} \mathrm{C}$ for $\mathrm{Al}$ ). Thus, irradiation-enhanced creep primarily controls the mechanical interaction between swelling fuel particles and $\mathrm{Al}$ matrix in Materials Testing Reactor (MTR) type dispersion fuel. For the HANS samples, irradiated between 475 and $700 \mathrm{~K}\left(200\right.$ and $\left.425^{\circ} \mathrm{C}\right)$, thermally activated creep is the controlling deformation mode.

An additional difference between hot-rolled dispersion fuel plates and the cold-compacted HANS samples is the relatively high porosity in the latter (see Fig. 4.8). The high creep rate and porosity of the Al matrix combine to lower the external force acting on the swelling fuel particles.

Interdiffusion of fuel and $\mathrm{Al}$ commonly occurs during irradiation at any temperature when intimate contact between fuel particle and matrix Al is established. Such contact is normally extensive in hot-rolled fuel plates, particularly after a certain amount of fuel swelling has eliminated the as-fabricated porosity that may have existed at the fuel-matrix interface. It is clear from Fig. 4.8 that in the cold-compacted HANS samples significant fractions of the fuel particle surface do not come in contact with the matrix Al during the entire irradiation and that, thus, no interdiffusion occurs at those locations.

Several annealing experiments with unirradiated $\mathrm{U}_{3} \mathrm{Si}_{2}-\mathrm{Al}$ dispersion fuel plates ${ }^{14-16}$ have shown that the interdiffusion results in the formation of $\mathrm{U}(\mathrm{Al}, \mathrm{Si})_{3}$, a singular phase with the $\mathrm{UAl}_{3}$ crystal structure wherein some of the $\mathrm{Al}$ atoms have been replaced by $\mathrm{Si}$ atoms. The two compounds $\mathrm{UAl}_{3}$ and $\mathrm{USi}_{3}$ are mutually soluble, as shown in the ternary phase diagram by Dwight ${ }^{17}$ (Fig. 4.9). The composition of the interaction phase lies in the vicinity of $\mathrm{U}_{25} \mathrm{Al}_{60} \mathrm{Si}_{15}$, i.e., where the tie-line between $\mathrm{U}_{3} \mathrm{Si}_{2}$ and $\mathrm{Al}$ crosses the singular USi $-U A \mathrm{U}_{3}$ phase field. Estimates of the width of the interaction zone as a function of time and temperature are shown in Fig. 4.10. Based on this correlation, one would expect an interaction zone of $<0.5 \mu \mathrm{m}$ in the $250^{\circ} \mathrm{C}$ HANS irradiation after $30 \mathrm{~d}$ and a similar value in the ORR irradiations after $300 \mathrm{~d}$ at 100 to $150^{\circ} \mathrm{C}$. The actual interaction zones are much thicker, as shown in Figs. 4.7 and 4.11, and the thickness appears to correlate well with the fission density.

One may conclude that the interdiffusion at low temperatures $\left(\leq 250^{\circ} \mathrm{C}\right)$ is fission enhanced. This conclusion is further supported by the results of an ORR irradiation of depleted $\mathrm{U}_{3} \mathrm{Si}_{2}-\mathrm{Al}$. The interaction zone is barely visible (see Fig. 4.12) after an irradiation of $\sim 250 \mathrm{~d}$ at the same neutron flux, but at a fission rate $1 \%$ 


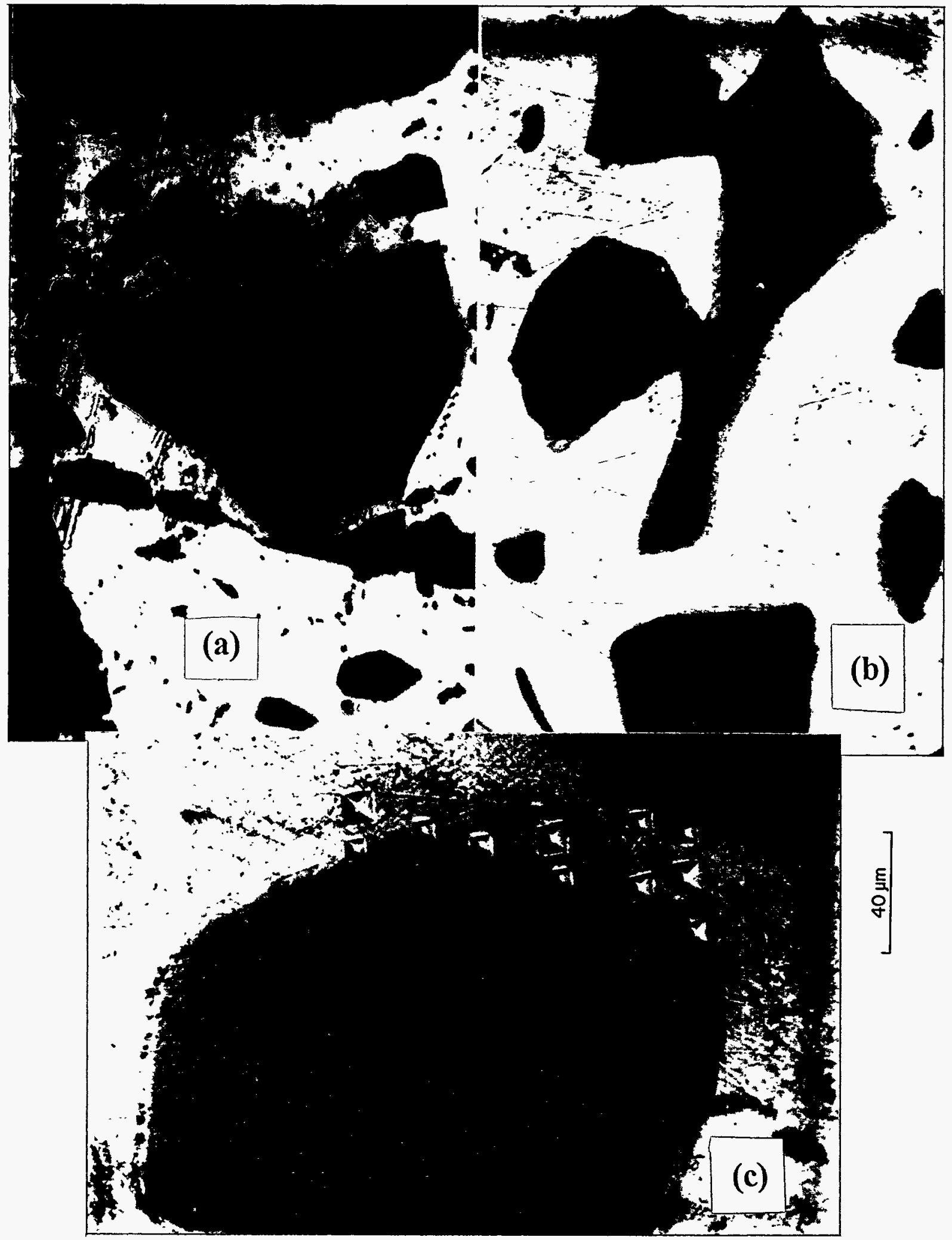

Fig. 4.7. Microstructure of LEU and HEU dispersion fuel irradiated in the ORR, showing Al-fuel interdiffusion zone surrounding fuel particles: (a) LEU, 95\% burnup; (b) HEU, $42 \%$ burnup; (c) HEU, 63\% burnup. 

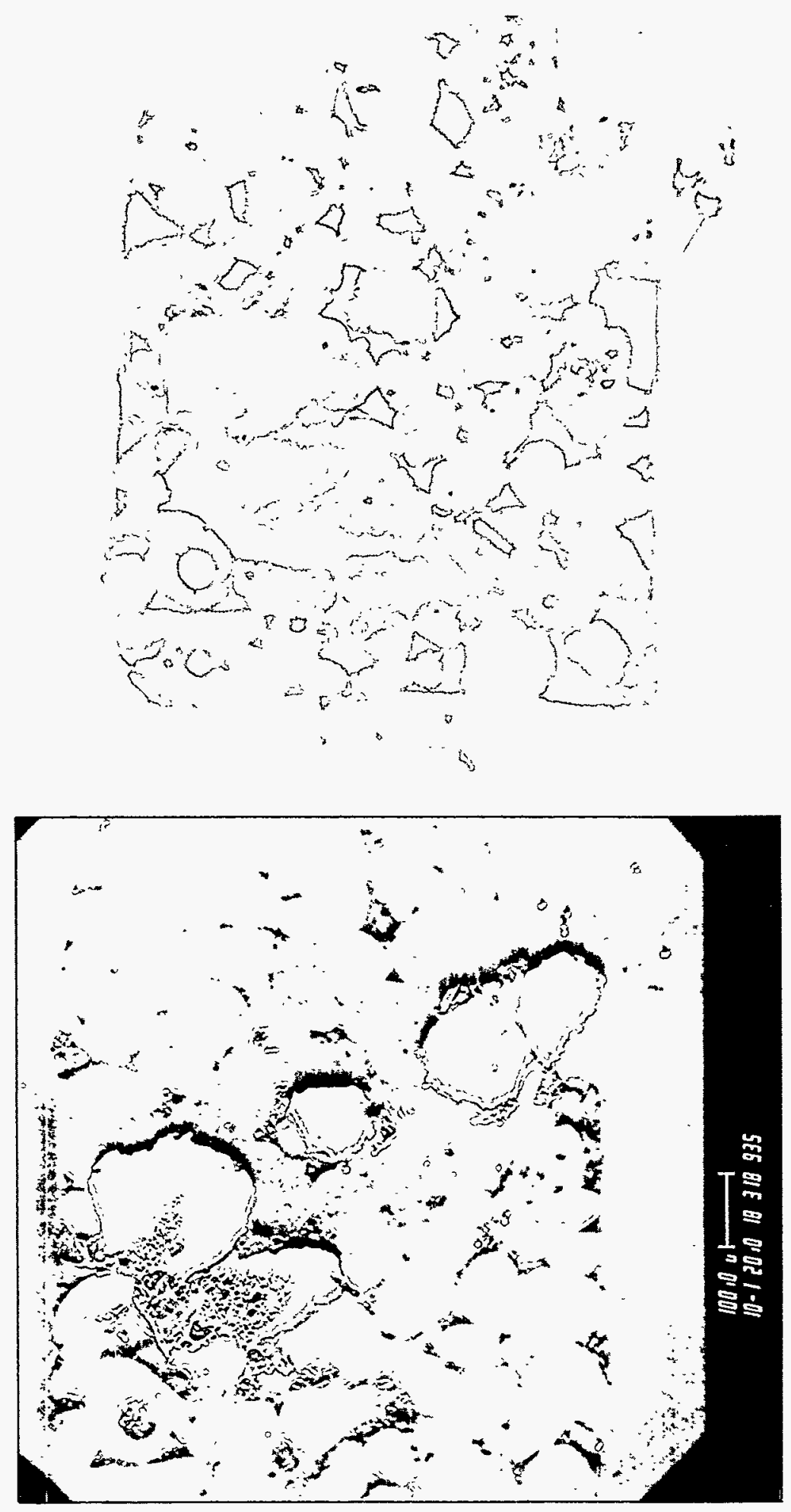

Fig. 4.8. Optical and SEM images of longitudinal section through HANS sample, showing areas with no Al-fuel contact. 


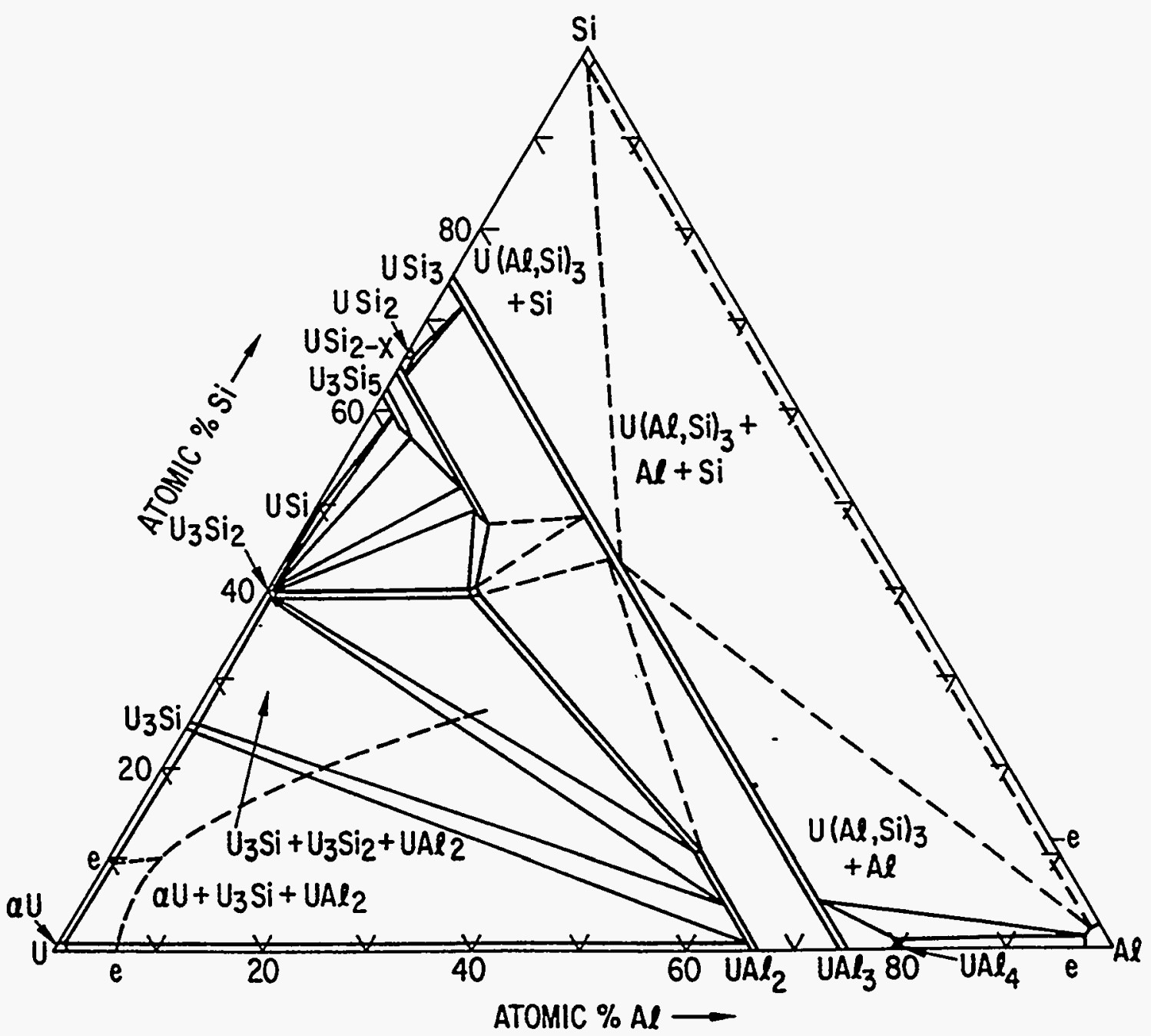

Fig. 4.9. Isothermal section of the U-Al-Si system at $400^{\circ} \mathrm{C}$. Source: Ref. 17. 


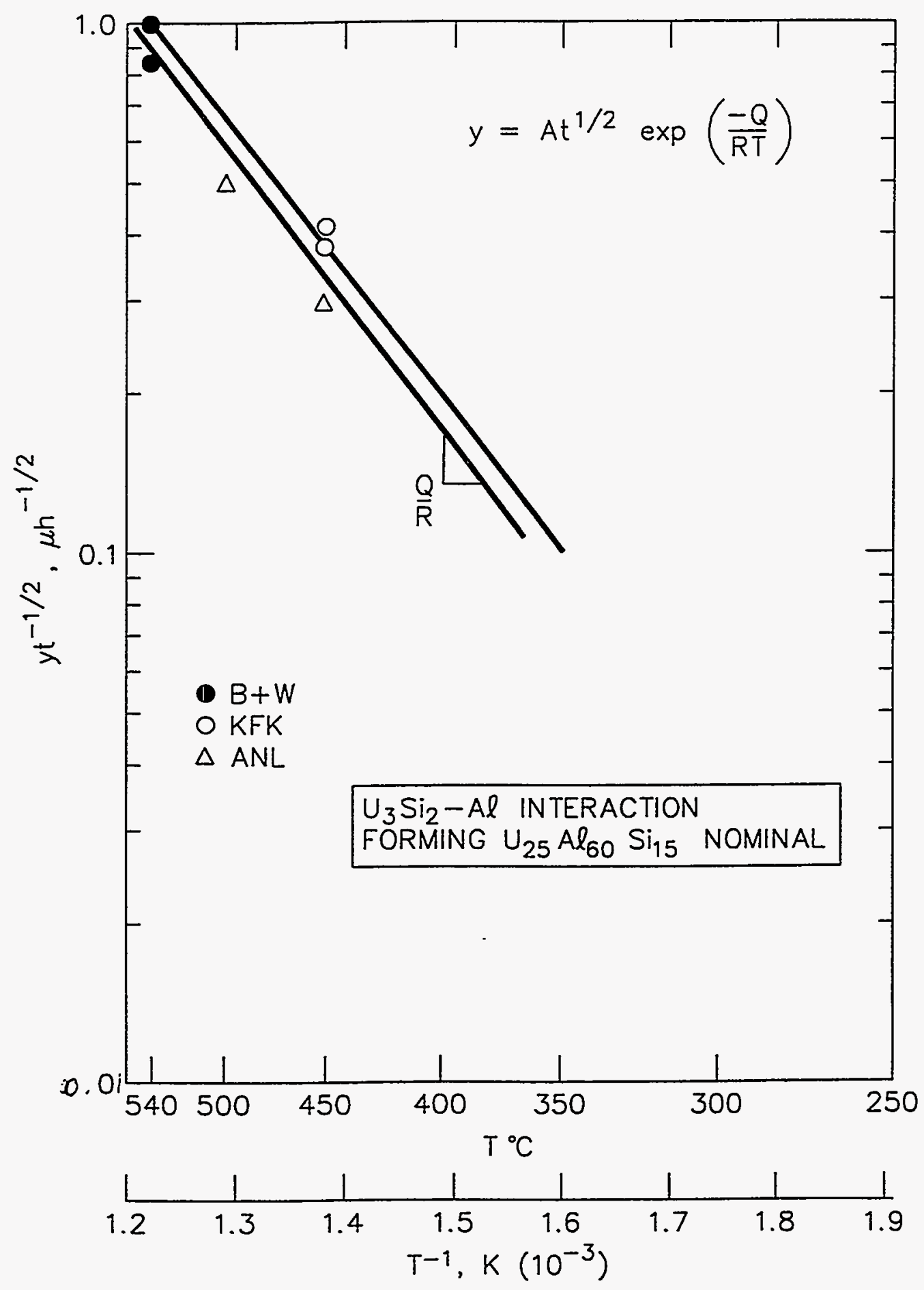

Fig. 4.10. Width of the $\mathrm{Al}-\mathrm{U}_{3} \mathrm{Si}_{2}$ interaction zone as a function of temperature. 


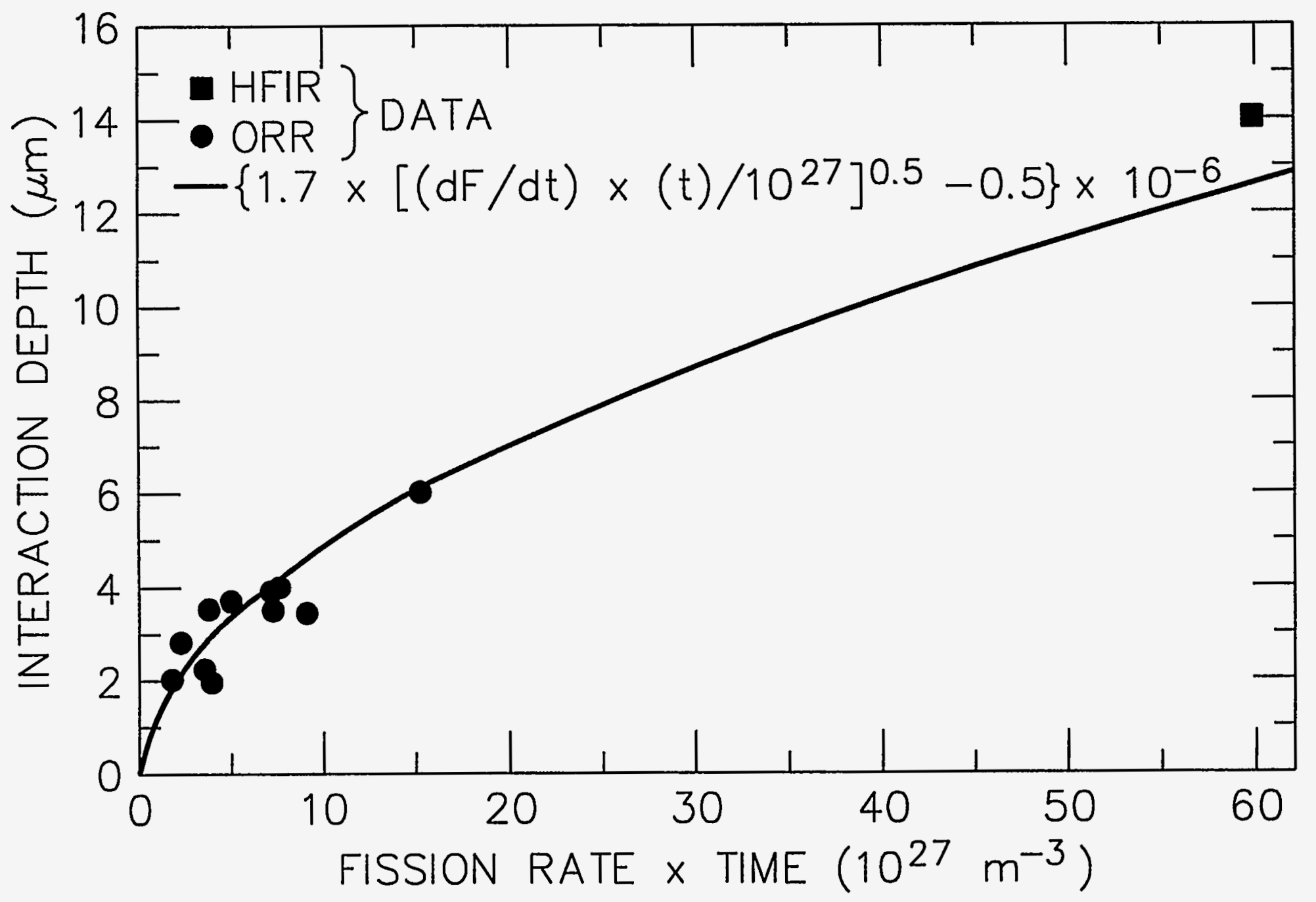

$\stackrel{t}{*}$

Fig. 4.11. Measured $\mathrm{Al}-\mathrm{U}_{3} \mathrm{Si}_{2}$ interaction zone width as a function of fission density $\left(\mathrm{T}<250^{\circ} \mathrm{C}\right)$. 


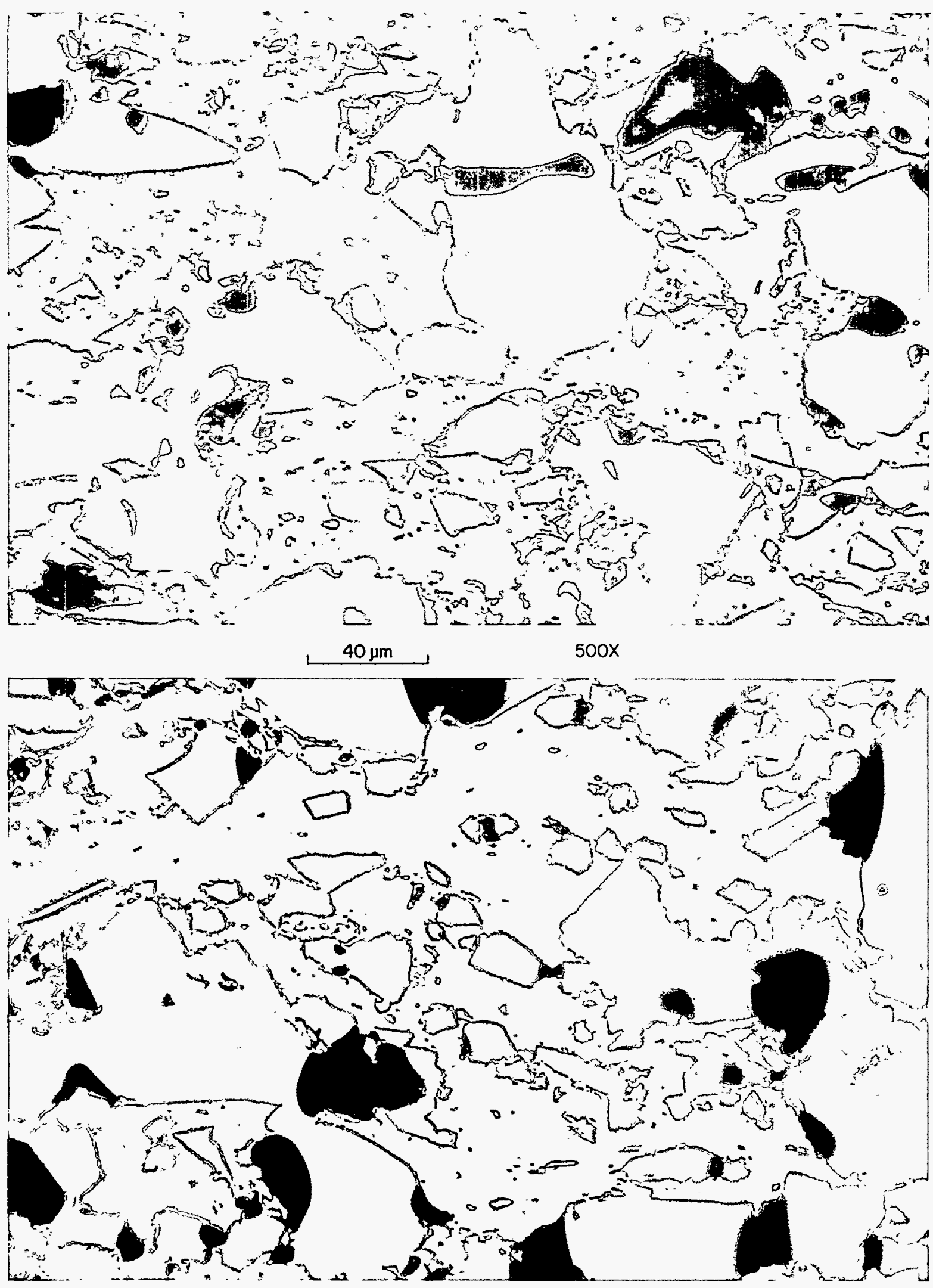

Fig. 4.12. Microstructure of depleted $\mathrm{U}_{3} \mathrm{Si}_{2}-\mathrm{Al}$ fuel plates irradiated for $\sim 250 \mathrm{~d}$ in the $\mathrm{ORR}$, showing absence of significant interaction. 
that of LEU sibling fuel test plates. For the higher-temperature HANS samples, the correlation shown in Fig. 4.10 predicts considerable interdiffusion, e.g., $7 \mu \mathrm{m}$ for an irradiation time of $30 \mathrm{~d}$ at $425^{\circ} \mathrm{C}$.

Comparison of the interdiffusion behavior in annealing tests of unirradiated fuel with that during irradiation is complicated not only by direct fission enhancement but also by substantial changes in the fuel chemistry as a result of $U$ burnup, particularly for the case of HEU in the HANS test where, at $~ 90 \%$ burnup, $84 \%$ of the original $U$ has been transmuted to fission product elements. The resulting chemical changes likely affect the diffusivities in the interaction zone, and indeed the width of the zone in the high temperature HANS samples appears to be larger than the out-of-reactor correlation predicts. For modeling purposes, the correlation is adjusted to match the experimental observations. Despite these chemical changes, the irradiation behavior of the material in the interdiffusion zone remains very stable (see Fig. 4.13) and continues to resemble the fission-gas-bubble-free microstructure of $\mathrm{UAl}_{3}$ up to high burnup. ${ }^{18}$

However, closer examination with the SEM suggests that the interaction phase at the particle periphery actually is composed of two different zones (see Fig. 4.14). Compositional analysis, using SEM energy-dispersive X-ray analysis (EDX) shows that the composition of these two zones is very similar and that their different appearance results from the differences in microstructure. This point will be elaborated in the discussion on fuel swelling.

The compositional analysis of the samples was difficult because of their high $\gamma$ activity. Several samples were ground down to reduce the number of fuel particles and thereby the intensity of the $\gamma$ radiation to the EDX detector. This was a delicate operation because of the small size of the dispersion samples and was only partially successful. Nevertheless, enough suitable samples were obtained to cover the temperature range in the HANS test. The results of the EDX analyses are listed in Table 4.4 both for the porous center and for the interaction zone at the periphery of representative fuel particles. Examination of the data reveals some inconsistencies. The U/Si ratio, which at 85 to $90 \%$ burnup should be around 0.4 , (see Fig. 4.15 ) is significantly lower-except for sample 18. Also the fraction of fission product elements is much lower than their calculated yield at this burnup because of the X-ray peak broadening and background scattering owing to the high $\gamma$ activity of most of the samples. Sample \#18 had a substantially lower $\gamma$ activity than the other samples, and the effect can be readily seen in the comparison of the X-ray energy spectra of sample \#18 and the more-radioactive sample \#17, shown in Fig. 4.16. In the more-radioactive sample, the peaks of $\mathrm{Si}$ as well as those of some fission products are poorly resolved, leading to inaccurate readings. The $\gamma$-ray background problem can be eliminated by using an electron microprobe (EMP), which utilizes $\mathrm{X}$-ray wave length dispersion rather than energy dispersion to detect the elements in a sample. This type of examination is much more time consuming and costly, however, and was performed on only one sample. The results of the microprobe analysis on sample 17, a highly radioactive sample, are shown in Table 4.5. A comparison with the EDX data in Table 4.4 shows that the EMP data are quite different. The U/Si ratio is commensurate with the ${ }^{235} \mathrm{U}$ burmup experienced by the sample. Also, the fraction of high-yield fission product elements detected at the particle center $(-35$ at. \% for $\mathrm{Mo}-\mathrm{Zr}, \mathrm{Nd}-\mathrm{Ce}$, $\mathrm{Tc}-\mathrm{Ru}$, and $\mathrm{Cs}$ ) is not far from the calculated value at $85 \%{ }^{235} \mathrm{U}$ burmup, namely, 30 at. \%. It is therefore assumed that the EMP results most accurately reflect the postirradiation composition. The less accurate but more readily obtainable SEM-EDX data are used in a relative sense, primarily to delineate zones of high and low $\mathrm{Al}$ in the fuel particles.

\subsection{2 $\mathrm{U}_{3} \mathrm{Si}_{2}$ Fuel Swelling}

Swelling of $\mathrm{U}_{3} \mathrm{Si}_{2}$ has been well characterized during the RERTR program. As shown in Fig. 1.3, swelling appears to proceed with fission density in two distinct stages. At the lower fission density stage, fission gas bubbles are not observed with the SEM, which has a resolution limit of $\sim 300 \AA$ ( $30 \mathrm{~nm}$ ) for features such as gas bubbles. This lack of observable bubbles is consistent with current fission gas behavior models, such as 


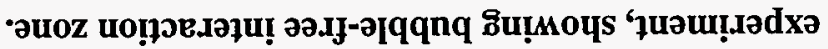

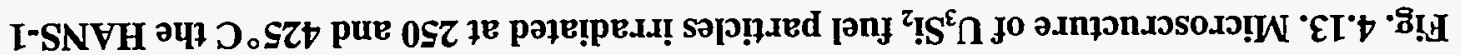

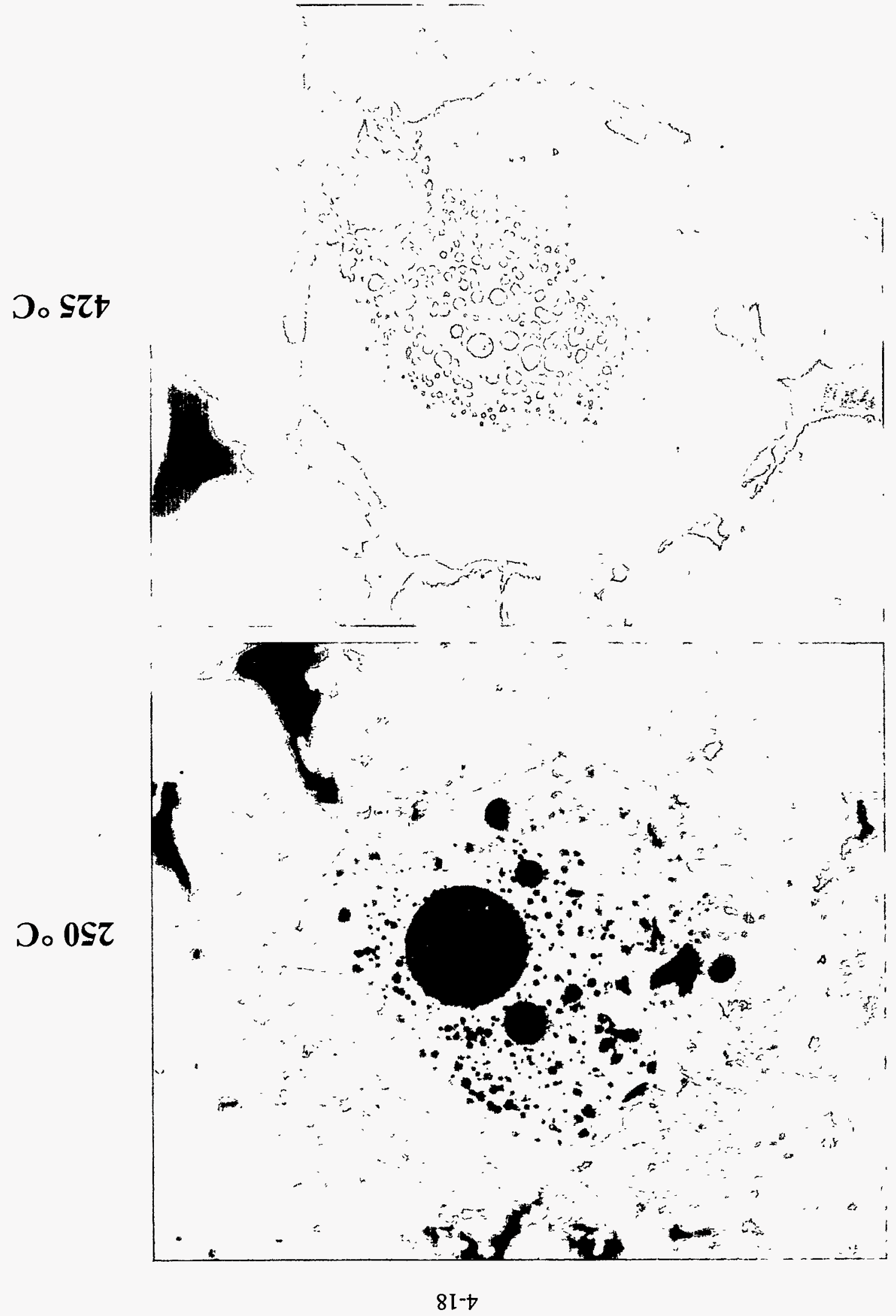




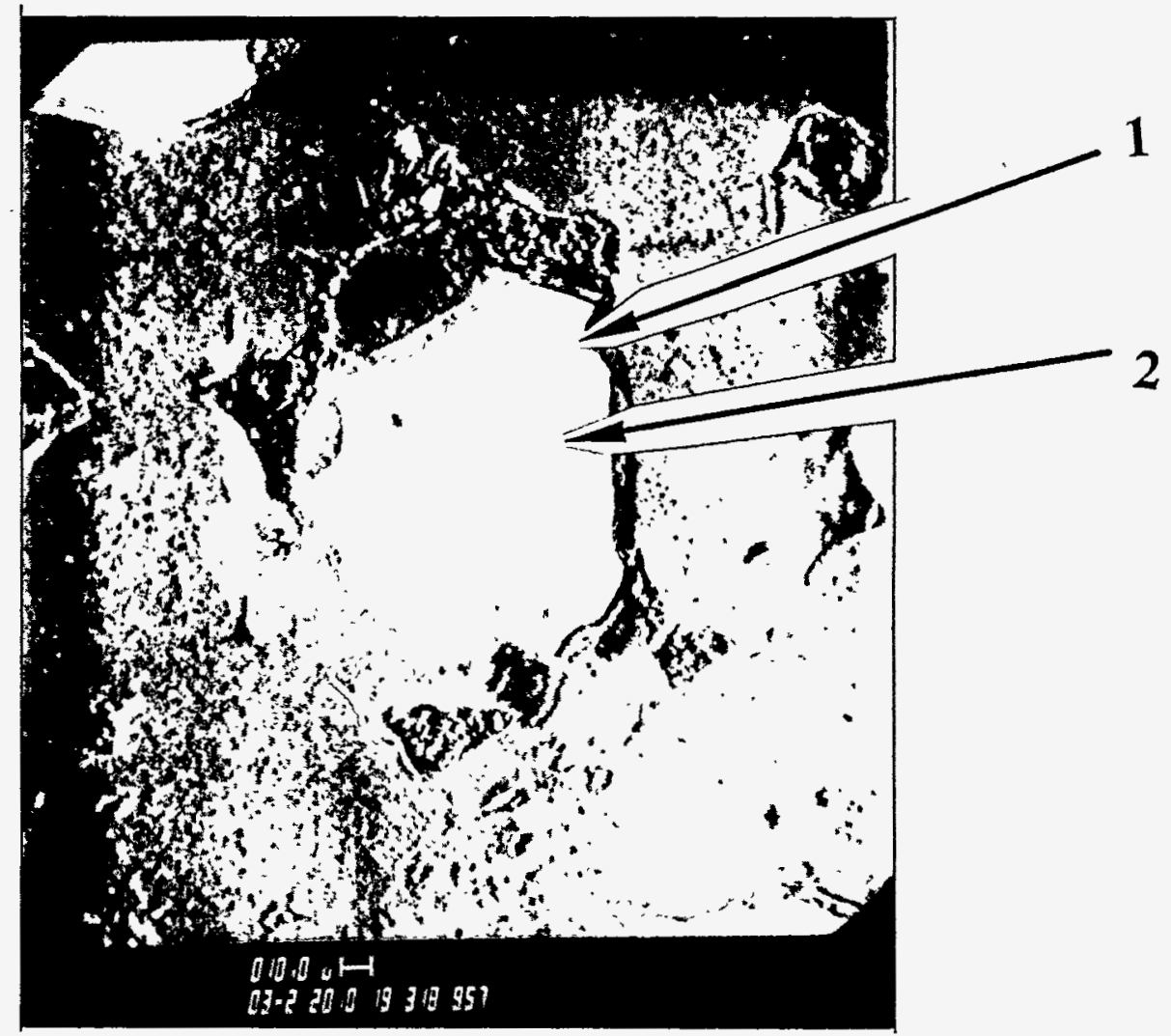

Fig. 4.14. SEM image of the interaction zone in $\mathrm{U}_{3} \mathrm{Si}_{2}$, showing presence of two zones.

Table 4.4. Compositional analysis by SEM-EDX of several $\mathrm{U}_{3} \mathrm{Si}_{2}$ samples from the HANS-1 experiment ${ }^{a}$

\begin{tabular}{|c|c|c|c|c|c|c|}
\hline Sample & $\begin{array}{c}\text { Temperature } \\
\left({ }^{\circ} \mathrm{C}\right)\end{array}$ & $\begin{array}{c}\mathrm{Al} \\
\text { (at. \%) }\end{array}$ & $\begin{array}{c}\mathrm{Si} \\
\text { (at. \%) }\end{array}$ & $\begin{array}{c}\mathrm{U} \\
\text { (at. \%) }\end{array}$ & $\begin{array}{l}\mathrm{U} / \mathrm{Si} \\
\text { ratio }\end{array}$ & $\begin{array}{l}\text { Fission products } \\
\text { (at. \%) }\end{array}$ \\
\hline \multicolumn{7}{|c|}{ Porous center of fuel particles } \\
\hline 2 & 375 & 29 & 55 & 5 & 0.09 & 11 \\
\hline 16 & 375 & 30 & 51 & 6 & 0.12 & 13 \\
\hline 17 & 325 & 21 & 61 & 8 & 0.13 & 10 \\
\hline 18 & 250 & 18 & 50 & 18 & 0.36 & 14 \\
\hline \multicolumn{7}{|c|}{ Periphery of fuel particles } \\
\hline 2 & 375 & 71 & 18 & 4 & 0.22 & 7 \\
\hline 6 & 250 & 63 & 20 & 5 & 0.25 & 12 \\
\hline 10 & 425 & 62 & 30 & 2 & 0.07 & 6 \\
\hline 16 & 375 & 70 & 18 & 5 & 0.28 & 7 \\
\hline 17 & 325 & 53 & 41 & 3 & 0.07 & 4 \\
\hline 18 & 250 & 63 & 19 & 7 & 0.37 & 11 \\
\hline
\end{tabular}

${ }^{a}$ Each entry represents an average of two or more data points. 

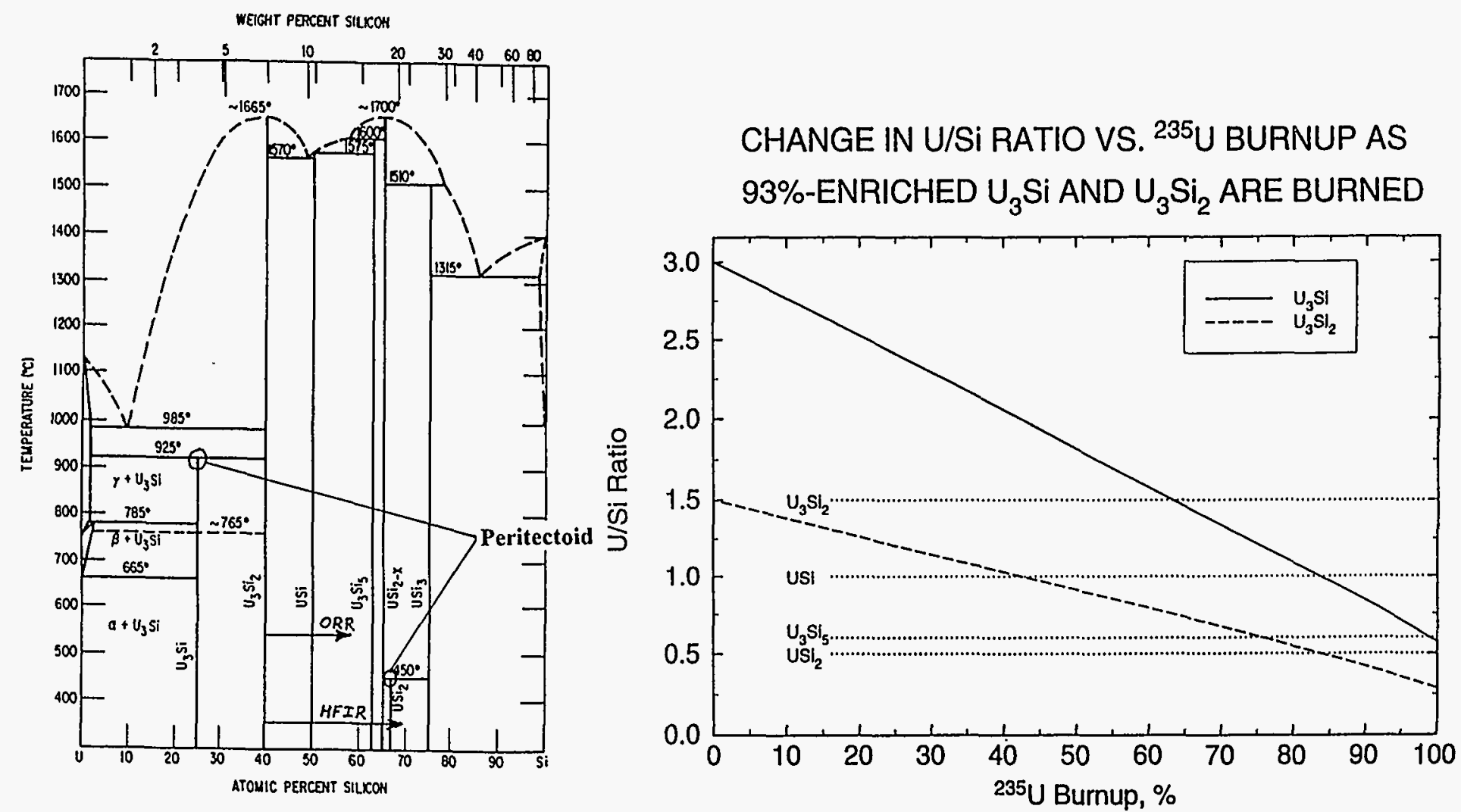

Fig. 4.15. $\mathrm{U}$-Si phase diagram and change in $\mathrm{U} / \mathrm{Si}$ ratio as $\mathrm{HEU} \mathrm{U}_{3} \mathrm{Si}$ and $\mathrm{U}_{3} \mathrm{Si}_{2}$ are burned. 


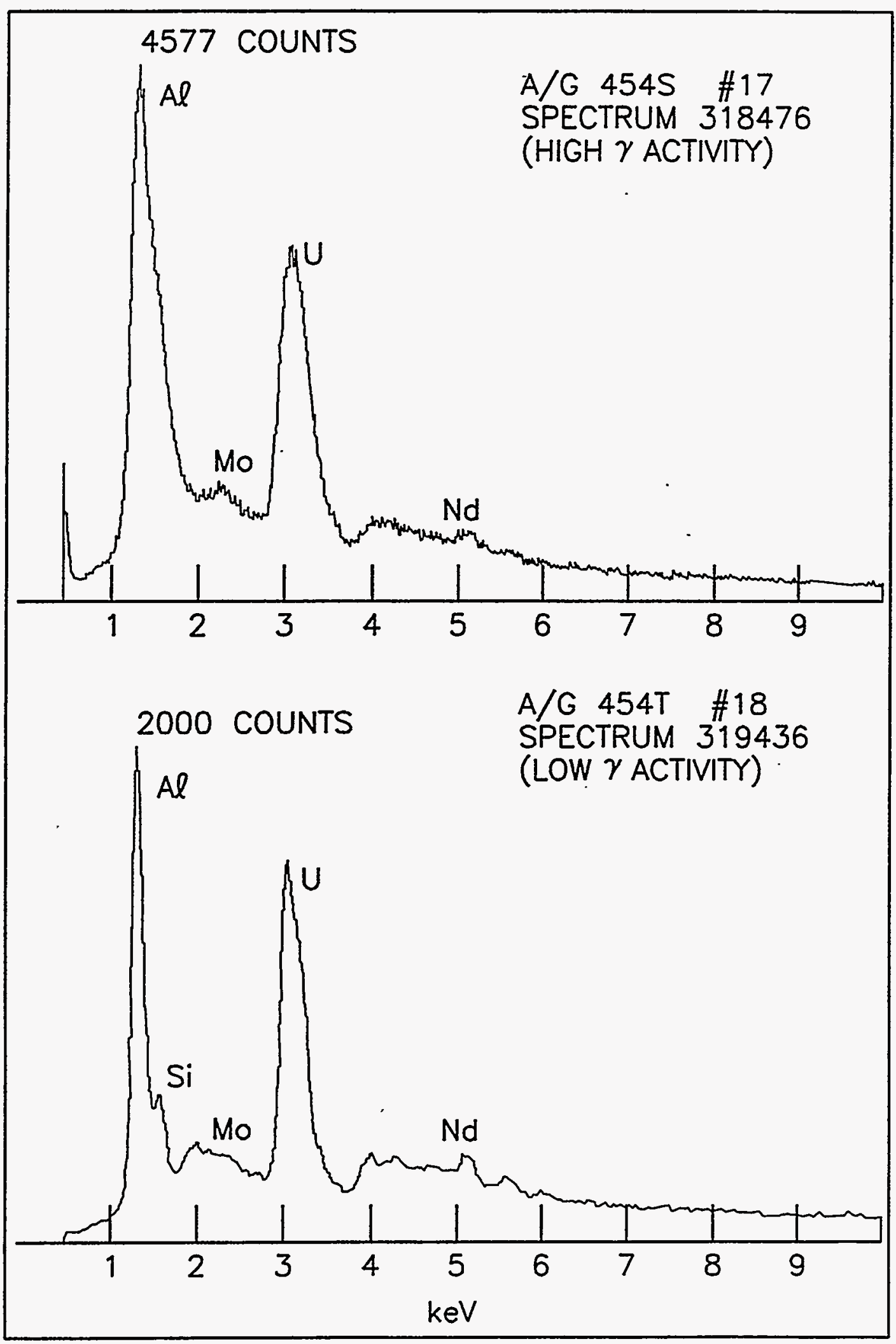

Fig. 4.16. X-ray energy spectra of HANS-1 samples 17 and 18. 
Table 4.5. Electron microprobe measurements on $\mathrm{U}_{3} \mathrm{Si}_{2}$ sample 17 from the HANS- 1 experiment, $325^{\circ} \mathrm{C}^{a}$

\begin{tabular}{lccccc}
\hline Location & $\begin{array}{c}\mathrm{Al} \\
\text { (at. \%) }\end{array}$ & $\begin{array}{c}\mathrm{Si} \\
\text { (at. \%) }\end{array}$ & $\begin{array}{c}\mathrm{U} \\
\text { (at. \%) }\end{array}$ & $\begin{array}{c}\text { U/Si } \\
\text { ratio }\end{array}$ & $\begin{array}{c}\text { Fission products } \\
\text { (at. \%) }\end{array}$ \\
\hline Porous center & 28 & 32 & 10 & 0.31 & 30 \\
Periphery & 53 & 22 & 7 & 0.32 & 18 \\
\hline
\end{tabular}

${ }^{\varpi}$ Each entry represents the average of three data points.

GRASS-SST, ${ }^{19}$ which predict the growth of bubbles of $100 \AA(10 \mathrm{~nm})$ diam in a crystalline fuel at low temperature, even at high fission densities. Such models thus describe the low fission density swelling stage, which is characterized by the accumulation of solid fission products and very small fission gas bubbles in the $\mathrm{U}_{3} \mathrm{Si}_{2}$ matrix. At around the transition from the low fission density to the high fission density stage (the "knee" in the swelling plot) gas bubbles are beginning to appear, as shown in Fig. 4.17. The difference between the two curves " $B$ " represents the additional swelling resulting from the volume of the gas bubbles.

From this point on, they rapidly multiply into a rather uniform population, as shown in Fig. 4.18. These gas bubbles grow in size with increasing fission density but do not interact, and, therefore, breakaway swelling does not occur in $\mathrm{U}_{3} \mathrm{Si}_{2}$ under these conditions. This fact is illustrated in Fig. 4.19, showing the gas bubble distribution in HEU irradiated in the ORR up to $\mathrm{a}^{235} \mathrm{U}$ burnup of $~ 63 \%\left(14 \times 10^{27}\right.$ fissions $\left.\mathrm{m}^{-3}\right)$. In addition to the complete lack of bubble linkup, there appear to be two distinct bubble-size distributions. Another observation made in the postirradiation analysis of $\mathrm{U}_{3} \mathrm{Si}_{2}$ was an apparent effect of fission rate on gas bubble development. As shown in Fig. 4.20, the swelling and bubble distribution for HEU are equivalent to those for LEU but at nearly twice the fission density. Since LEU and HEU were irradiated under the same reactor conditions, the only distinguishing parameter is the rate of ${ }^{235} \mathrm{U}$ fissioning.

As mentioned before, existing fission gas behavior models did not allow the calculation of the observed bubble morphology and also did not provide an explanation for the apparent fission rate effect. The GRASS-SST code did, however, predict the correct bubble size on grain boundaries, if present. Indeed, as seen in Fig. 4.18(a), such bubbles are occasionally observed well before the second swelling stage at rare grain boundaries (the ground fuel particles are chiefly pieces of grain, i.e., single crystals). When the models in GRASS-SST were modified by the ad hoc introduction of small subgrains, at the "knee" in the swelling plot, with a size suggested by the bubble patterns in Figs. 4.19 and 4.20, the observed bubble morphology in the second swelling stage could be modeled. The fission rate effect was modeled by making the occurrence of the grain subdivision (or grain refinement) dependent on fission rate. Support for this phenomenon was found in earlier observations of fission-induced grain refinement in uranium oxides. ${ }^{20}$ It will be shown in the following discussion of the HANS tests that grain refinement does in fact occur in $\mathrm{U}_{3} \mathrm{Si}_{2}$

Although the stable and predictable swelling behavior of $\mathrm{U}_{3} \mathrm{Si}_{2}$ experienced in the RERTR program boded well for the ANS fuel, the much more severe projected operating conditions are well beyond the existing data base. Temperature, fission rate, and burnup are all substantially higher, and the HANS tests that covered the ANS parameter range did indeed show some new aspects in the irradiation behavior of $\mathrm{U}_{3} \mathrm{Si}_{2}$.

The most remarkable feature is the presence of an irregular distribution of relatively large fission gas bubbles at the centers of practically all fuel particles. Examples representing the range of irradiation temperatures in the HANS test are shown in Fig. 4.21. Apart from the peripheral zones that have been transformed to some aluminum compound, as described in the preceding section, the fuel appears to have reached a breakaway swelling stage in which bubbles interlink and grow to rather large size. 


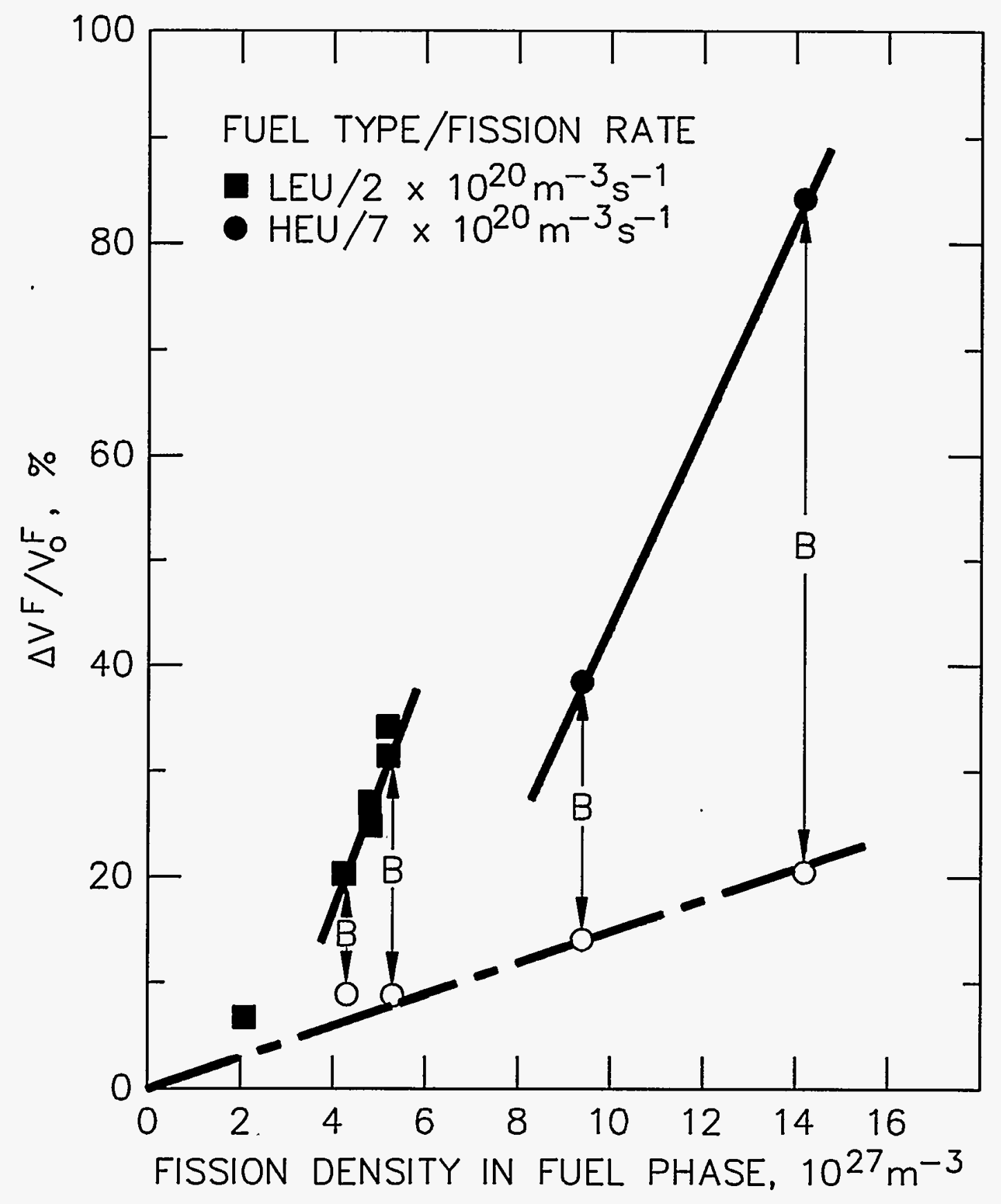

Fig. 4.17. Swelling behavior of $\mathrm{U}_{3} \mathrm{Si}_{2}$. The quantity " $\mathrm{B}$ " is the measured swelling owing to fission gas bubbles visible in the SEM. The open circles represent the difference between the measured gross swelling (from immersion density) and the measured swelling owing to gas bubbles. 

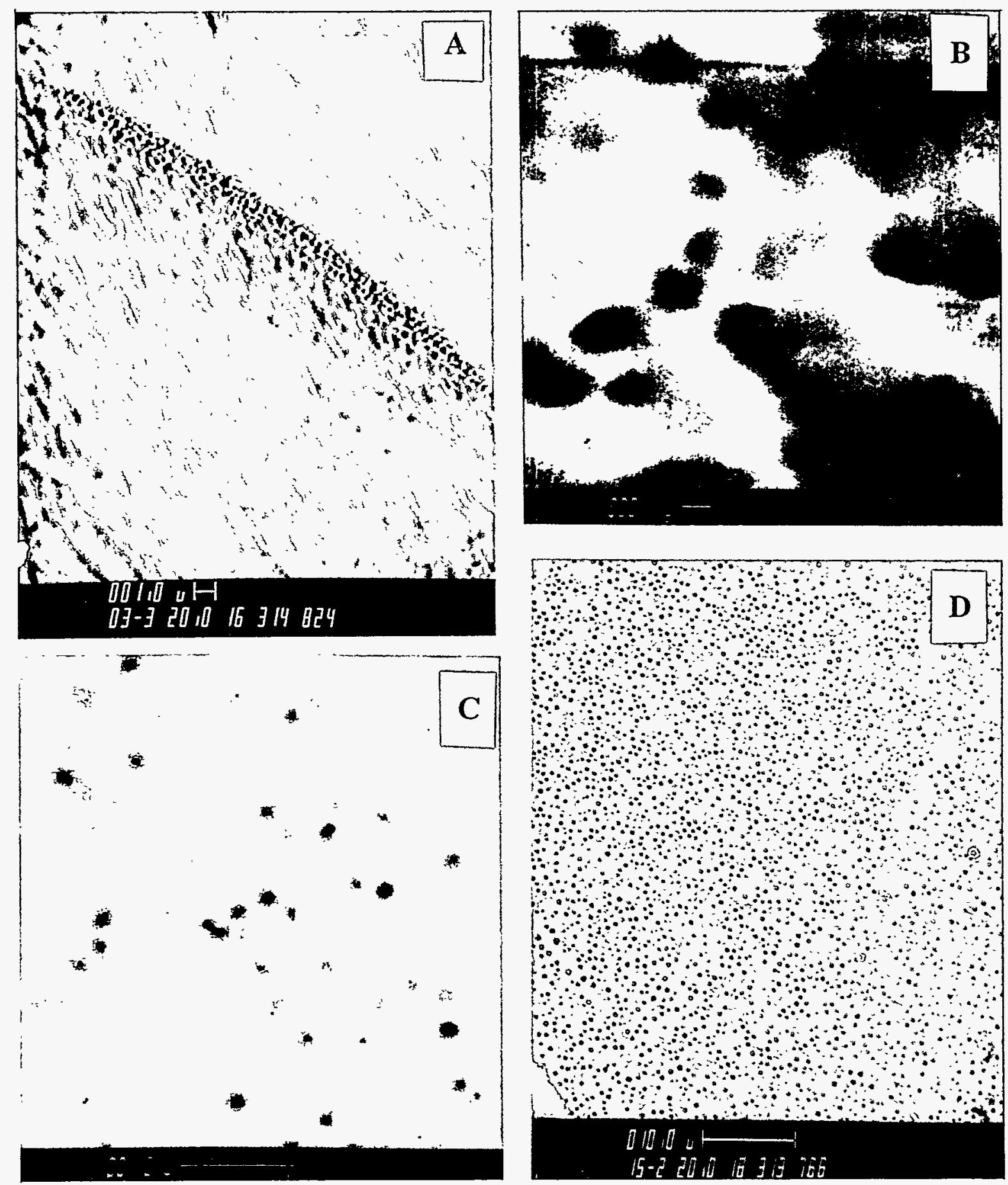

Fig. 4.18. SEM images of $\mathrm{U}_{3} \mathrm{Si}_{2}$, showing evolution of fission gas bubbles. (a) Bubbles formed before the "knee" of the swelling curve on an original grain boundary (sample is ion etched), (b) and (c) first evidence of fission gas bubbles in $\mathrm{LEU} \mathrm{U}_{3} \mathrm{Si}_{2}$ forming just at the "knee" of the swelling curve, (d) uniform bubble population beyond the "knee" of the swelling curve. 

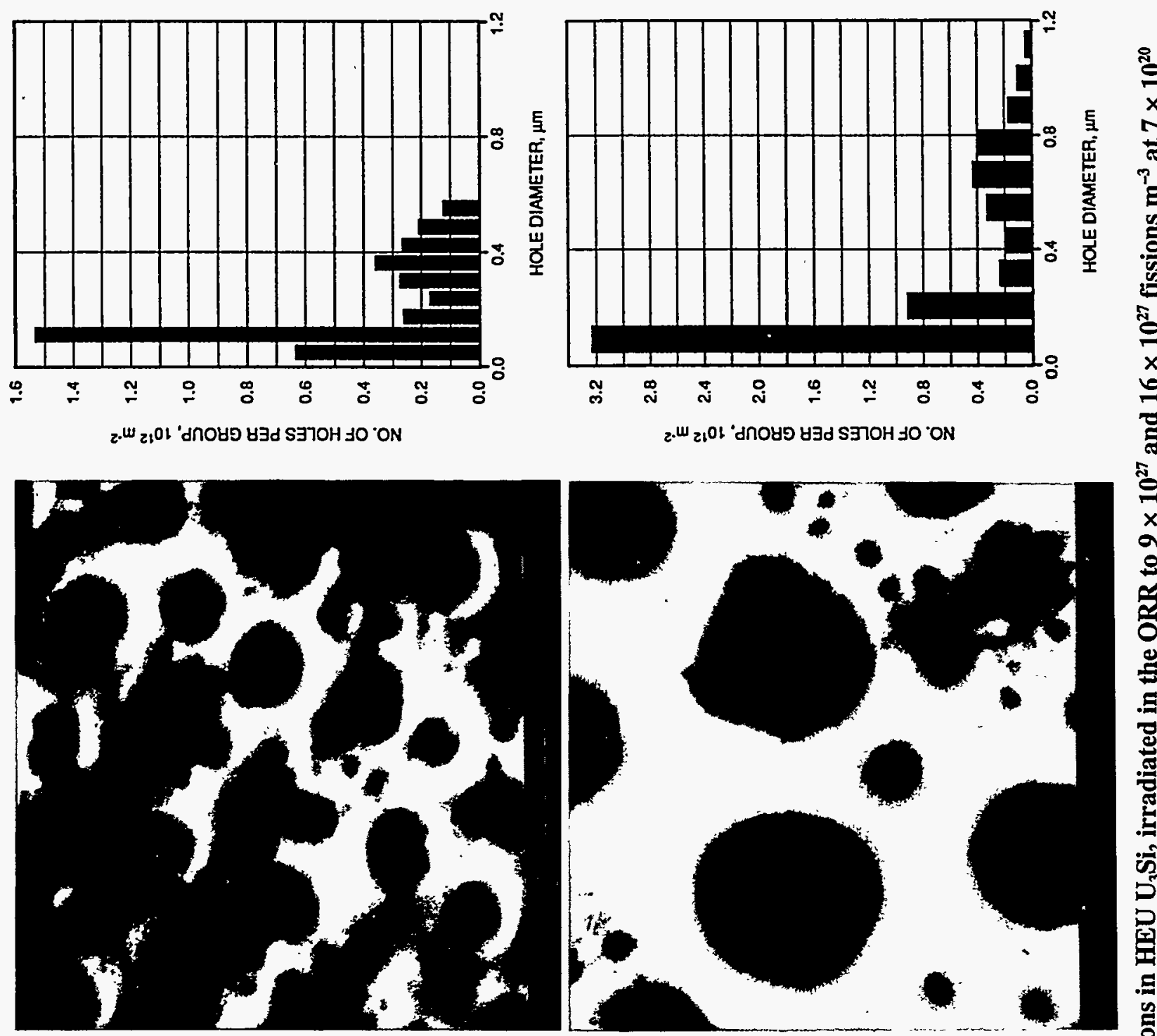

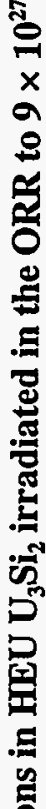

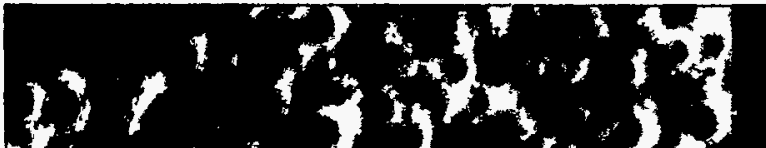

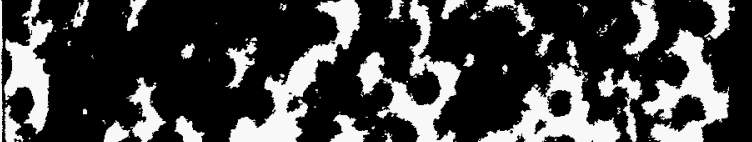

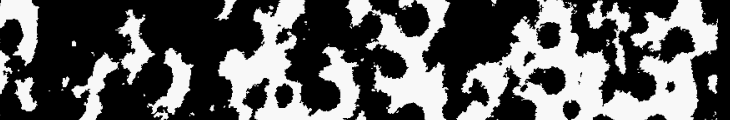

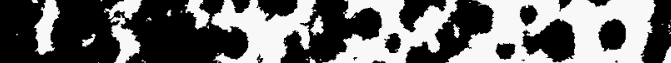

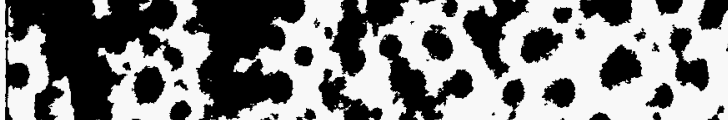

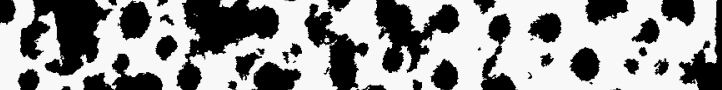

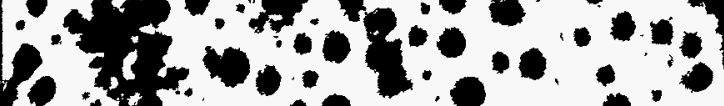

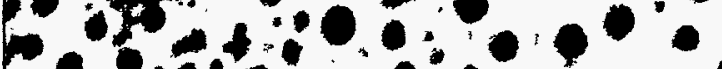

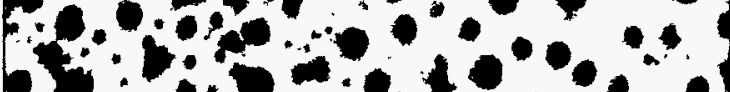
4 tes

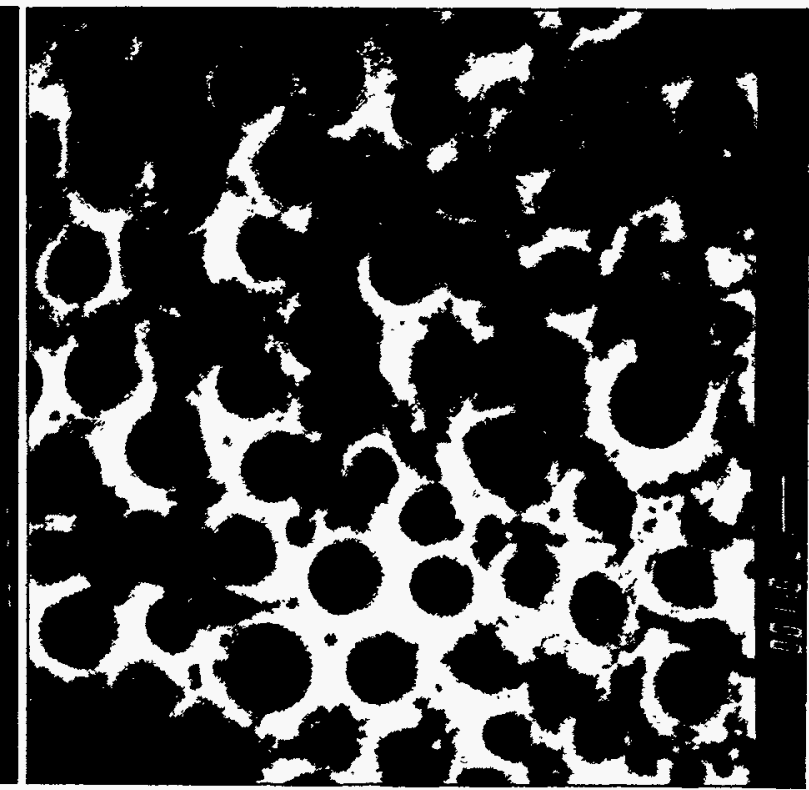
年 

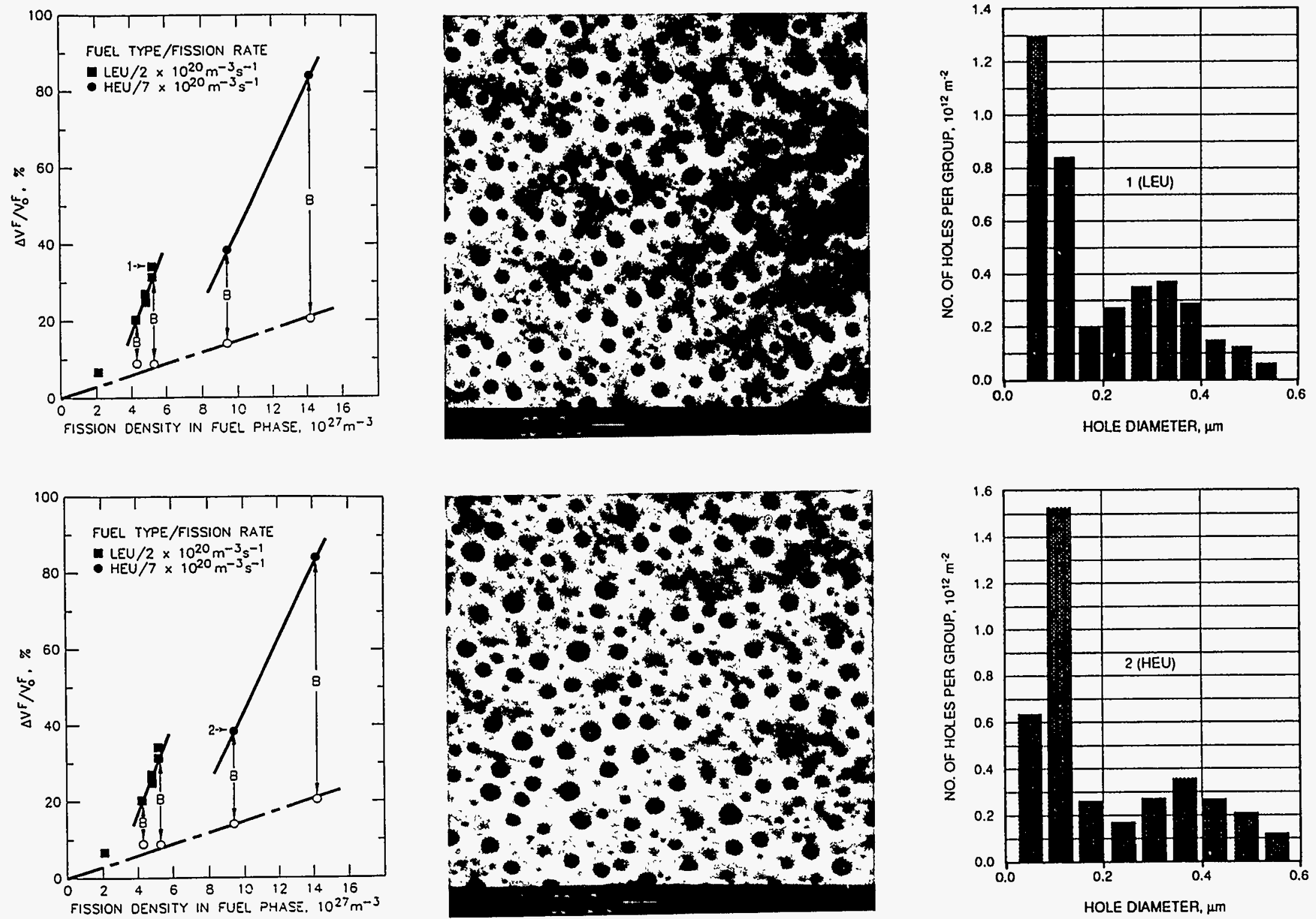

Fig. 4.20. Fission gas bubble distributions of $L E U$ (upper) and $\mathrm{HEU}$ (lower) $\mathrm{U}_{3} \mathrm{Si}_{2}$ irradiated in the ORR. 


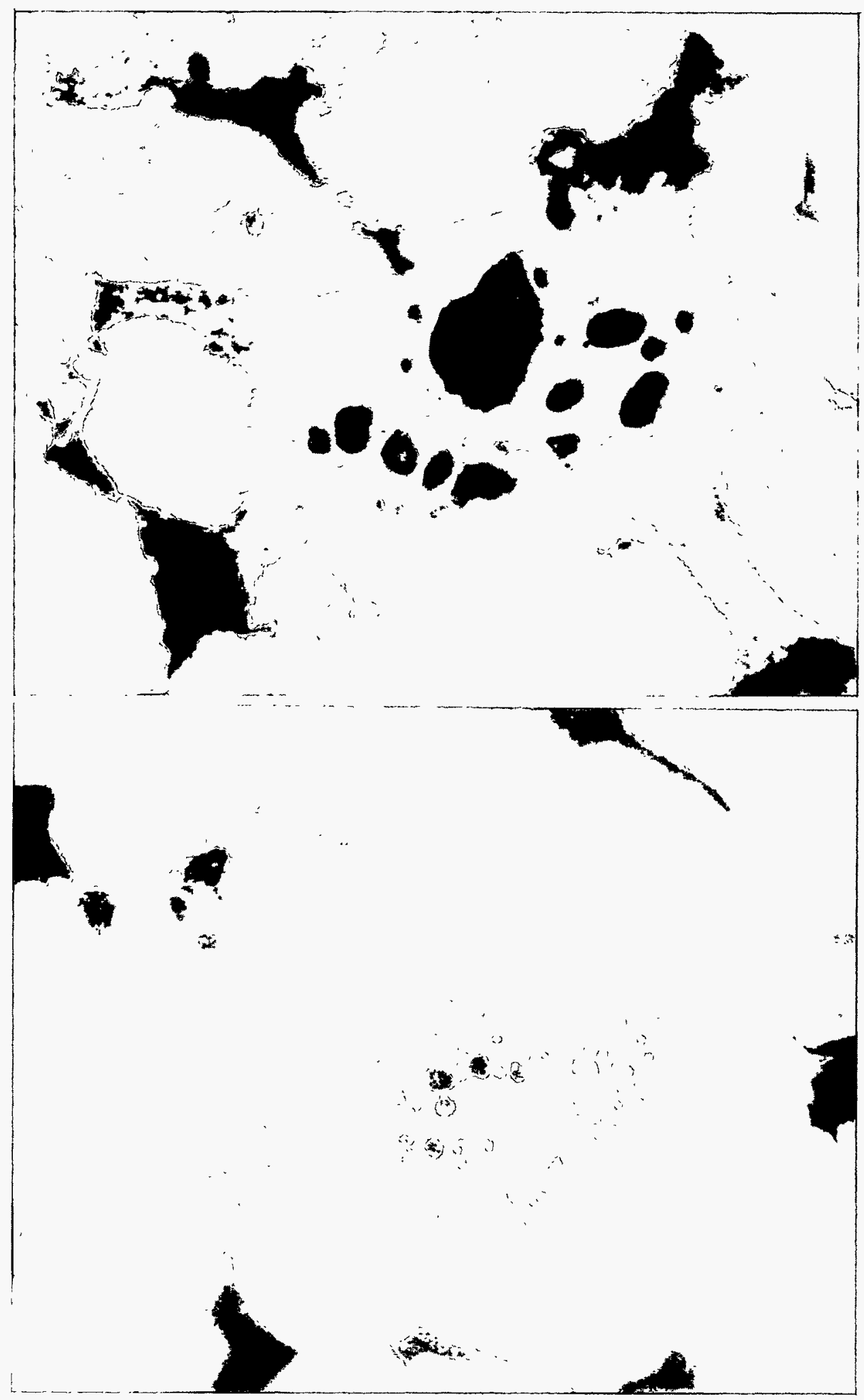

Fig. 4.21. Microstructures of $\mathrm{U}_{3} \mathrm{Si}_{2}$ fuel particles irradiated in the HANS-1 experiment at 250 and $425^{\circ} \mathrm{C}$, showing the presence of large bubbles at the centers of the fuel particles. 
Some particles appear bubble free, but this effect is simply the result of the random section through the sample, by which some particles are cut through their bubble-free peripheral zone rather than their centers. The often-observed asymmetric patterns are a result of the cold compaction of the sample, which left voids at the fuel particle-aluminum interface. These voids are also the site of oxide accumulation. If, as would be the case for a roll-bonded dispersion, the fuel particles were completely encased and in intimate contact with the aluminum matrix, the peripheral zone and central porous zone would be concentric. This expectation is clearly supported by the sequence of serial sections through two adjacent particles shown in Fig. 4.22.

One of the lowest burnup samples (sample 18) has some very interesting features in its porous center. This is a $250^{\circ} \mathrm{C}$ sample and therefore has a small aluminide zone and conversely a large porous center zone, as shown in Fig. 4.23. In most of this center zone, the gas bubbles are clearly coarsening, and the fuel is in breakaway swelling except for some areas (marked " $A$ " in Fig. 4.23) that look very similar to the lower-burnup ORR HEU fuel shown in Fig. 4.7(c). It seems that this sample is in a transition from "typical" $\mathrm{U}_{3} \mathrm{Si}_{2}$ gas bubble behavior to a breakaway mode. The other higher-burnup samples have all made this transition at the end of the HANS irradiation period. It may be concluded that the centers of all particles up to a certain burnup, perhaps $\sim 80 \%$, had the uniform bubble patterns characteristic of $\mathrm{U}_{3} \mathrm{Si}_{2}$.

As was noted in the preceding section on fuel-Al interaction, the bubble-free (high-Al) zone at the particle periphery actually comprises two structurally different subzones that are revealed by SEM examinations (see Fig. 4.24). At high magnification, it appears that only the outer zone is truly gas bubble-free with the featureless appearance characteristic of UAl. The intermediate zone, while having an Al content similar to that of the outer zone, has a distinct substructure resembling small grains. The boundaries of these grains are visible in the SEM image shown in Fig. 4.25, most likely because fission gas has collected on them. More defined gas bubbles are present at several grain boundary junctions. This substructure is very similar to that observed previously in uranium oxides and forms the basis for the fission gas behavior model.

\subsection{3 $\mathrm{U}_{3} \mathrm{Si}_{2}$ Irradiation Behavior Model}

A detailed description of the irradiation behavior model of $\mathrm{U}_{3} \mathrm{Si}_{2}-\mathrm{Al}$ is presented in a report on the DART code by J. Rest ${ }^{21}$ and in several publications written during the course of this project and referenced in the DART code report. The metallurgical understanding that has evolved from the RERTR tests through the HANS experiments, which forms the basis for the models used in the DART code, can be summarized as follows.

At a certain burnup or corresponding fission density, $\mathrm{U}_{3} \mathrm{Si}_{2}$ undergoes complete recrystallization into submicron-size grains, a process referred to as "grain refinement." Fission gas precipitates on the boundaries and boundary junctions between these small new grains, resulting in a rather uniform, bimodal distribution of noninteracting gas bubbles that grow in size with increasing fission density.

Prior to the recrystallization event, fission gas forms very small bubbles in the original $\mathrm{U}_{3} \mathrm{Si}_{2}$ matrix, so small that they cannot be seen with the SEM. This change in fission gas behavior results in two stages of swelling as a function of fission density, where the swelling rate in the second stage is approximately three times that of the first stage. The onset of the second stage shifts to a higher fission density with increasing fission rate. At very high fission density corresponding to $\sim 80 \%$ HEU burnup, the regular fission gas bubble distribution breaks down and breakaway swelling occurs in that part of the fuel that is no longer uranium silicide but rather an unknown alloy of $\mathrm{Si}$, fission product, and a minor fraction of $\mathrm{U}$.

Aluminum diffusion into the fuel takes place during the entire irradiation. At $250^{\circ} \mathrm{C}$ and below, the diffusion rate is athermal and fission enhanced. At higher temperatures thermal activation determines the diffusivity. Diffusion of $\mathrm{Al}$ occurring prior to recrystallization results in an aluminide-type $\mathrm{U}(\mathrm{Al}, \mathrm{Si})_{3}$ interaction zone. Continued diffusion after recrystallization may transform a second zone into small-grained $\mathrm{U}(\mathrm{Al}, \mathrm{Si})_{3}$. Minor Al diffusion may extend into the center of the fuel particle without affecting the transformation to aluminide, but this $\mathrm{Al}$ may have an effect on the final breakaway swelling behavior at the fuel particle centers. These concentric zones thus formed each have their own characteristic irradiation behavior, as illustrated in Fig. 4.26. 


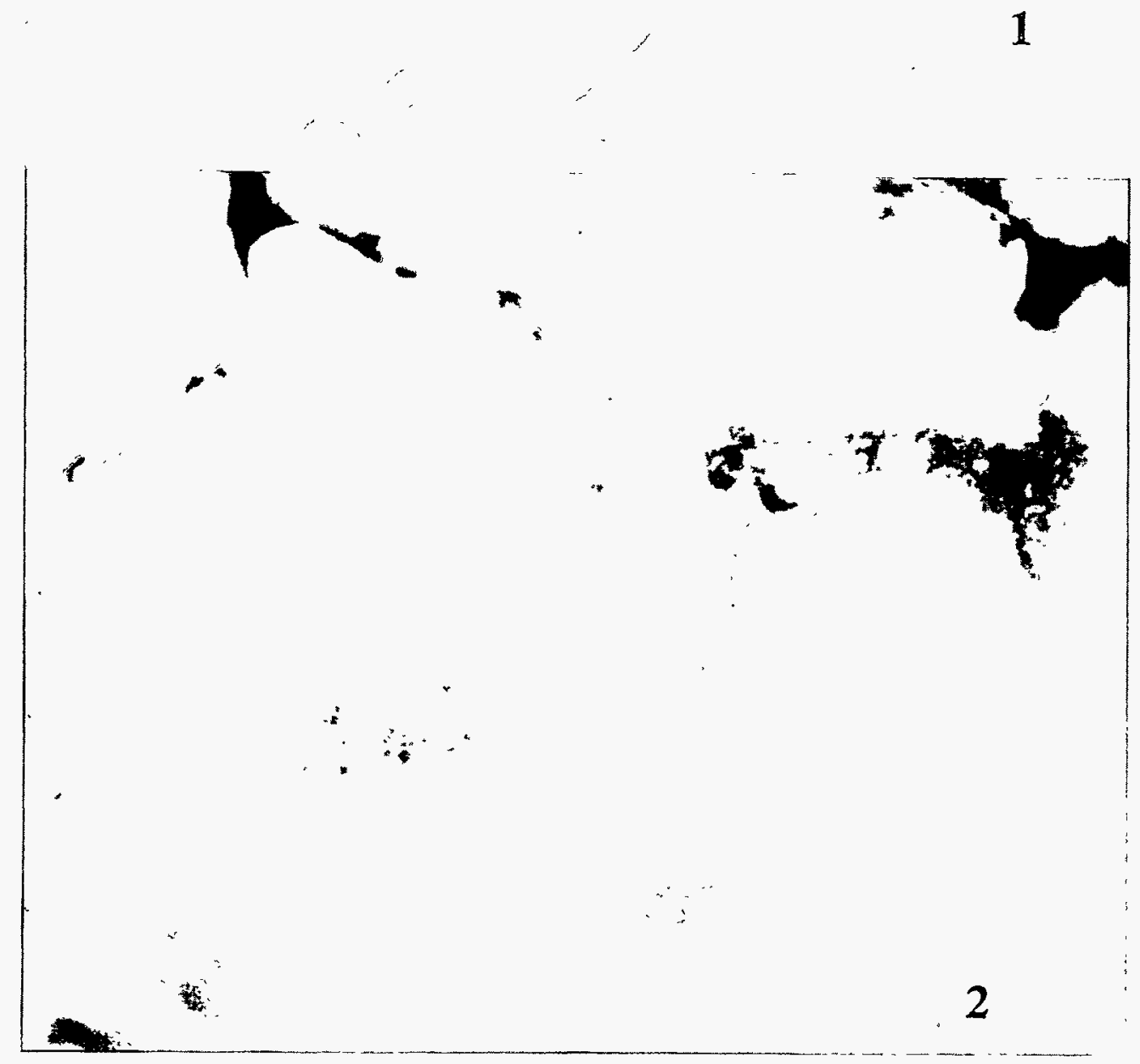

Fig. 4.22. Serial sections through a $\mathrm{U}_{3} \mathrm{Si}_{2}$ fuel particle irradiated in the HANS-1 experiment at $425^{\circ} \mathrm{C}$ to $\sim 90 \%$ burnup. 

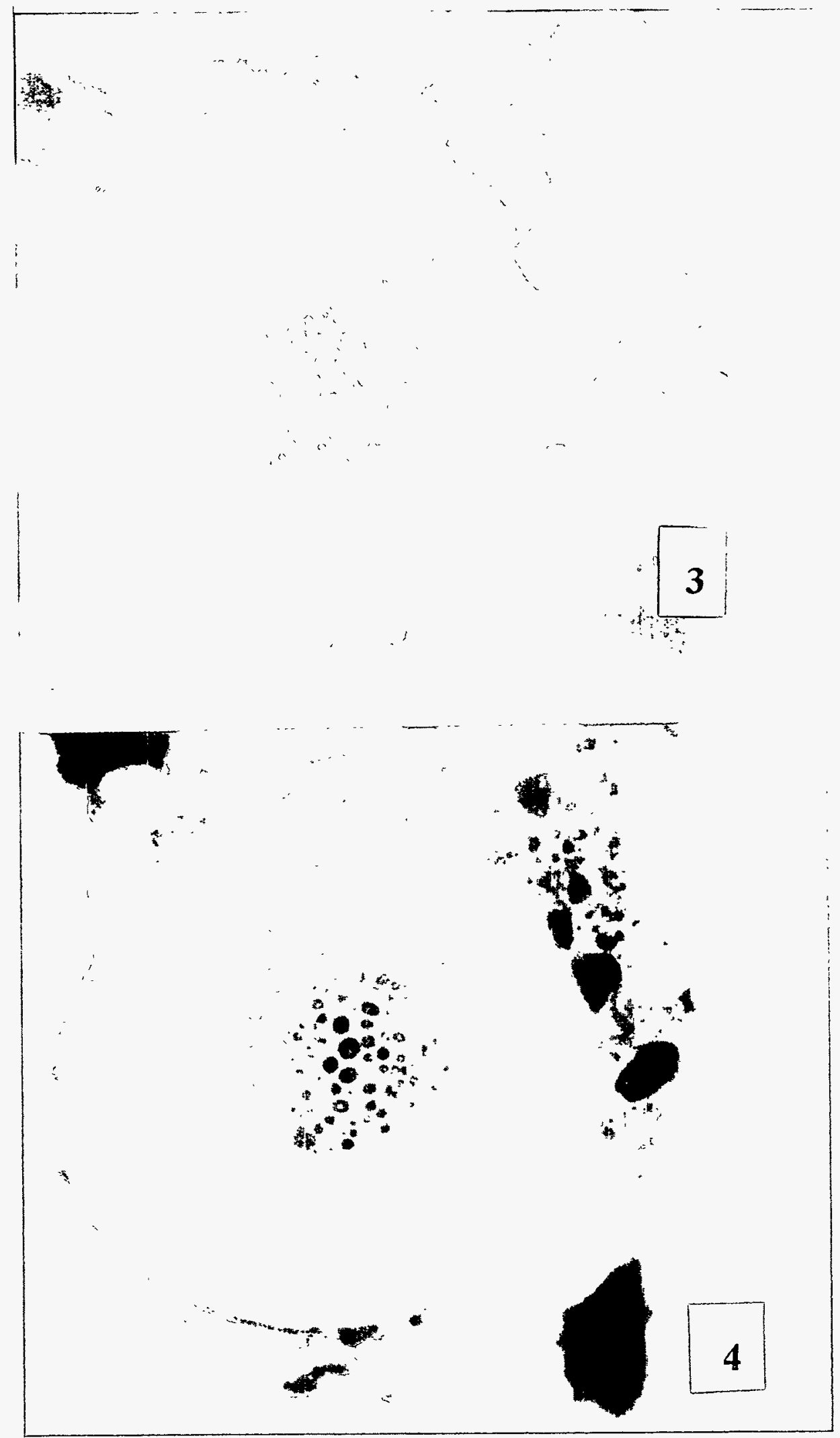

Fig. 4.22 (continued). Serial sections through a $\mathrm{U}_{3} \mathrm{Si}_{2}$ fuel particle irradiated in the HANS-1 experiment at $425^{\circ} \mathrm{C}$ to $\sim 90 \%$ burnup. 


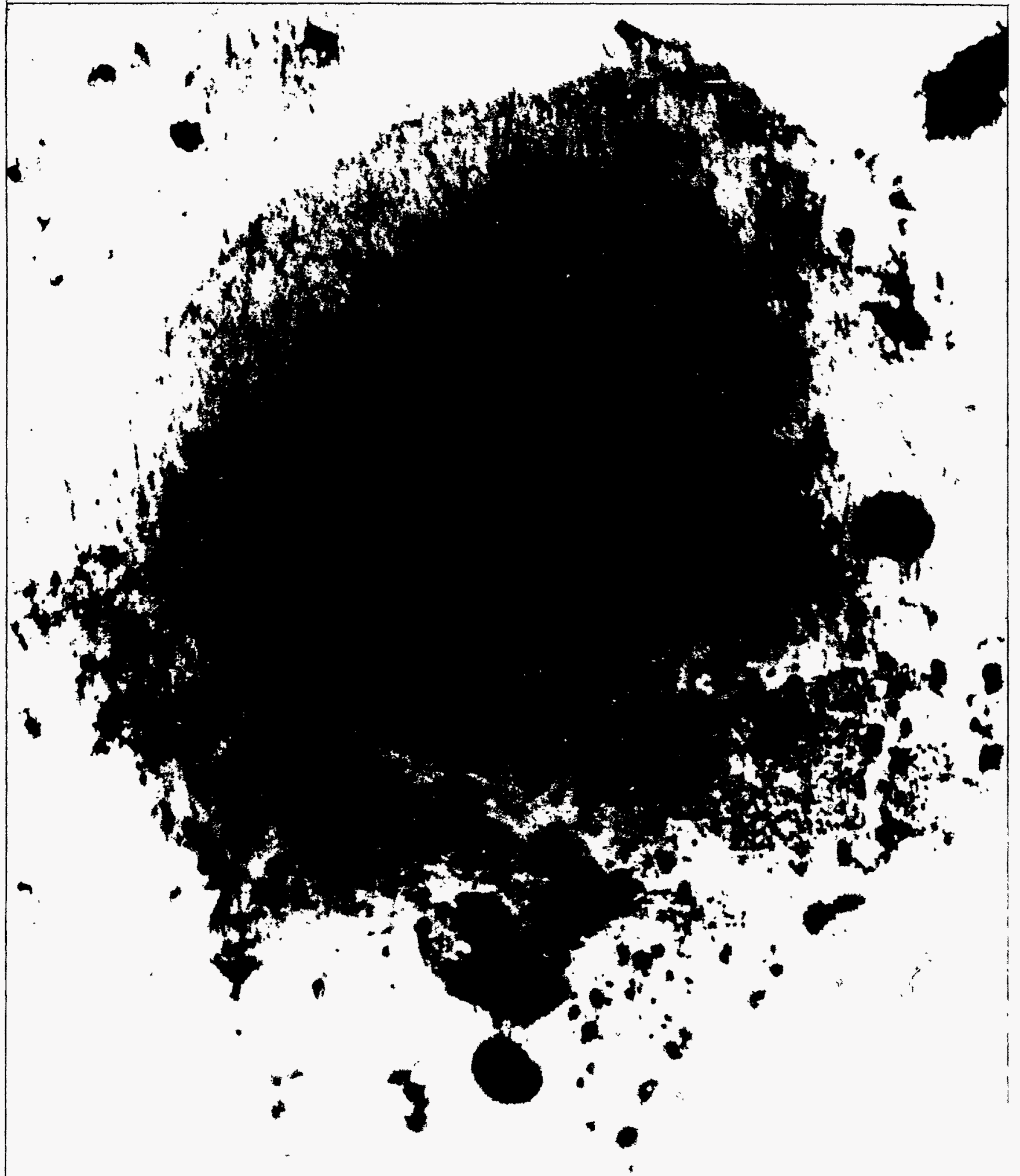

Fig. 4.23. Bubble morphology in a $\mathrm{U}_{3} \mathrm{Si}_{2}$ fuel particle irradiated in the HANS-1 experiment at $250^{\circ} \mathrm{C}$ to $\sim \mathbf{8 5 \%}$ burnup, showing region of small, uniform bubbles. 

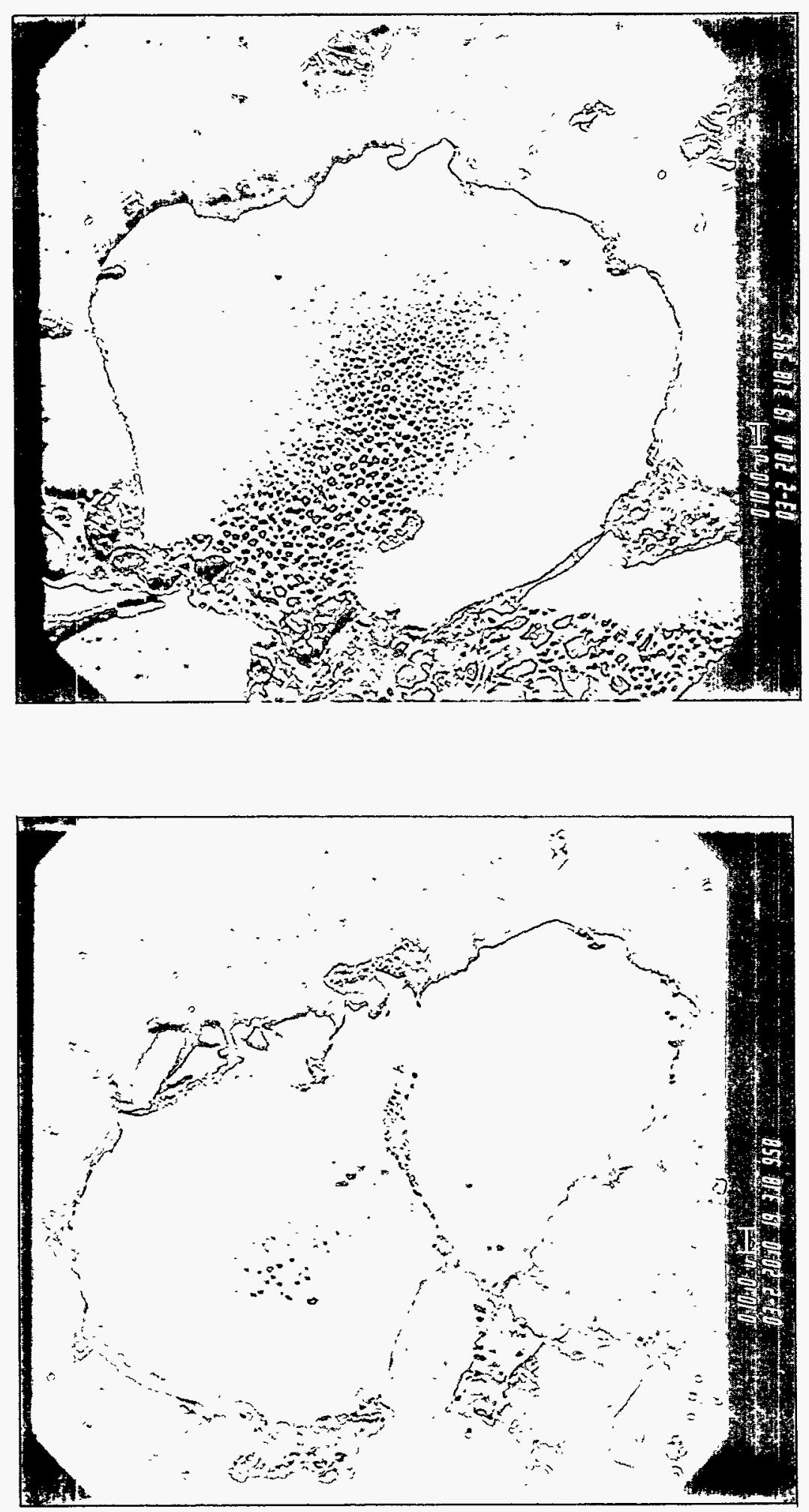

Fig. 4.24. Microstructural zones in $\mathrm{U}_{3} \mathrm{Si}_{2}$ irradiated in the HANS-1 experiment to $\sim 90 \%$ burnup. 


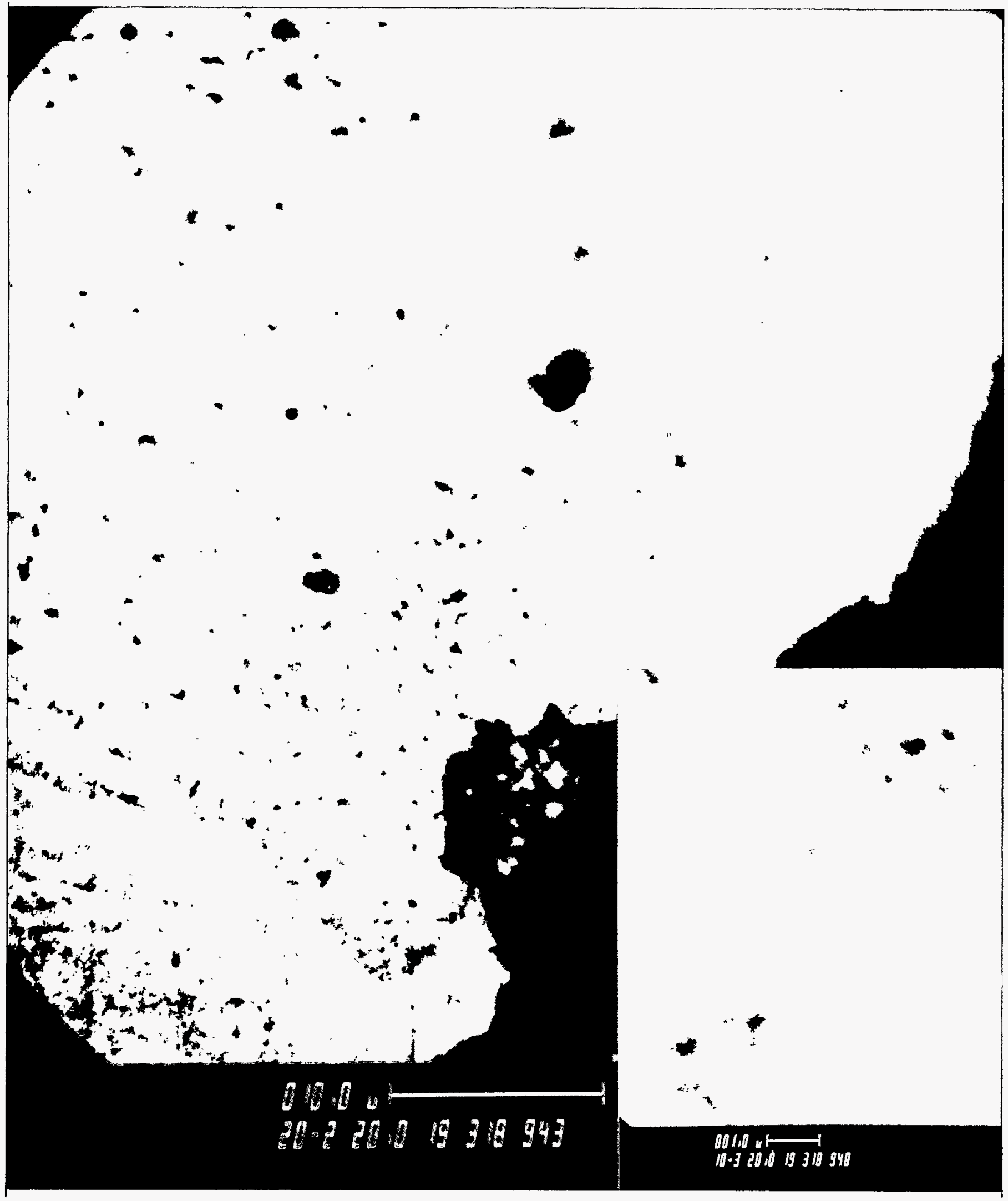

Fig. 4.25. Evidence of small grains in a $\mathrm{U}_{3} \mathrm{Si}_{2}$ fuel particle irradiated in the HANS-1 experiment. 

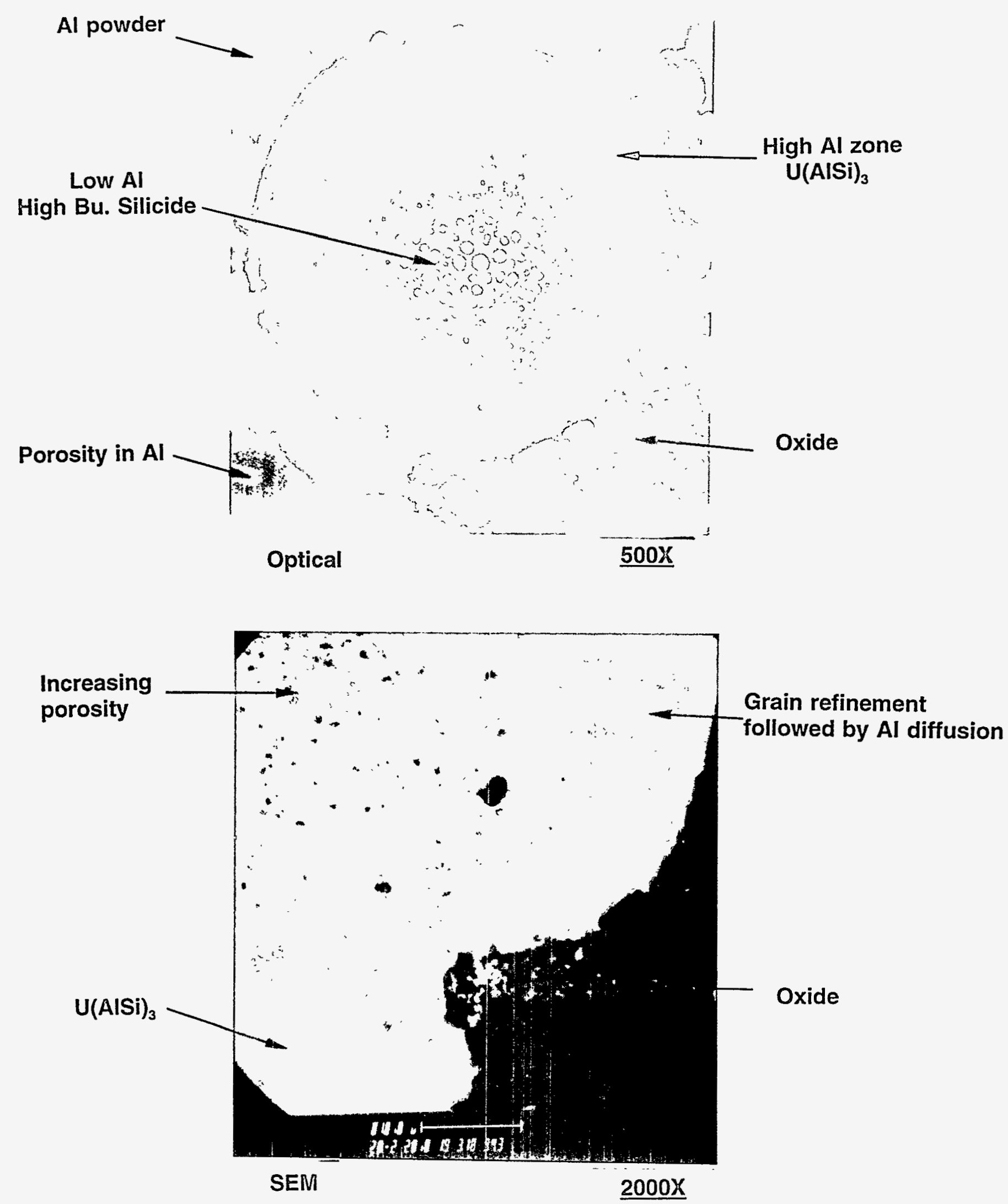

Fig. 4.26. Various zones described in the $\mathrm{U}_{3} \mathrm{Si}_{2}$ irradiation behavior model. 


\subsubsection{Backup Fuels}

As mentioned in Sect. 1, several other fuel compounds in addition to $\mathrm{U}_{3} \mathrm{Si}_{2}$ were included in the HANS tests. HANS- 1 contained only $\mathrm{U}_{3} \mathrm{Si}$ samples, but HANS-2 contained $\mathrm{UAl}_{x}, \mathrm{UAl}_{2}$, and $\mathrm{U}_{3} \mathrm{O}_{8}$.

The highest-density silicide compound, $\mathrm{U}_{3} \mathrm{Si}$, was included to test our general interpretation of silicide irradiation behavior. It had been found in the RERTR program that $\mathrm{U}_{3} \mathrm{Si}$ exhibited breakaway swelling at medium burnup. This behavior was ascribed to a crystalline-to-amorphous transformation induced by fission events..$^{22}$ Above a certain temperature $\left(-350^{\circ} \mathrm{C}\right)$, such transformation does not occur, and $\mathrm{U}_{3} \mathrm{Si}$ remains crystalline. It has been hypothesized that $\mathrm{U}_{3} \mathrm{Si}$ in this crystalline state would not be susceptible to breakaway swelling. The HANS test appears to confirm this hypothesis, as the $<250^{\circ} \mathrm{C}$ samples indeed showed the expected breakaway gas bubble growth, but in the $375^{\circ} \mathrm{C}$ sample, shown in Fig. 4.27, large interconnected gas bubbles are entirely absent, as expected in a crystalline compound at this temperature.

The effect of temperature on the irradiation behavior of $\mathrm{U}_{3} \mathrm{O}_{8}$ was just as profound as that in $\mathrm{U}_{3} \mathrm{Si}$. This compound has been thoroughly tested since the $1950 \mathrm{~s}$ at temperatures up to $300^{\circ} \mathrm{C}$. It was found that $\mathrm{U}_{3} \mathrm{O}_{8}$ reacts with $\mathrm{Al}$ to form a multiphase reaction product consisting of $\mathrm{UAl}_{4}$ and $\mathrm{Al}_{2} \mathrm{O}_{3}$. At high burnup, fission gas bubbles of rather large size develop in this reaction product. ${ }^{23}$ In the HANS test, the low-temperature samples $\left(250^{\circ} \mathrm{C}\right)$ did exhibit the familiar, large breakaway-type gas bubbles. However, even though it had completely reacted with the surrounding $\mathrm{Al}$, the $425^{\circ} \mathrm{C}$ sample showed a total absence of such bubbles (see Fig. 4.28). One of the reaction phases, $\mathrm{Al}_{2} \mathrm{O}_{3}$, does become amorphous by fission damage, and it has been suggested that the large gas bubble growth occurs in this phase. ${ }^{24} \mathrm{It}$ is possible that at $425^{\circ} \mathrm{C} \mathrm{Al}_{2} \mathrm{O}_{3}$ remains crystalline and, as is the case for $\mathrm{U}_{3} \mathrm{Si}$, is therefore more stable with respect to gas bubble formation.

The uranium aluminide compounds $\mathrm{UAl}_{2}$ and $\mathrm{UAl}_{3}$ are known to react with matrix aluminum to form, respectively, $\mathrm{UAl}_{3}$ and $\mathrm{UAl}_{4}$, during irradiation and at moderate temperatures of $\sim 400$ to $500^{\circ} \mathrm{C}$ even without the presence of fission events. The aluminide compounds have always exhibited exceedingly stable swelling behavior; in fact, fission gas bubbles such as those seen in silicides have never been observed in $\mathrm{UAl}_{\mathrm{x}}$. In the HANS test, however, a breakdown of this stable behavior was observed, as shown in Fig. 4.29. This is most likely the combined result of high $U$ burnup, which has the result of moving the fully reacted fuel particles into the two-phase field beyond $\mathrm{UAl}_{4}$ into the $\mathrm{U}$-Al phase diagram, and high temperature. The high-burnup fuel thus consists of $\mathrm{UAl}_{4}$ and some Al-fission product phase. This effect is particularly evident at temperatures above $250^{\circ} \mathrm{C}$, where fuel-Al interaction has been most thorough. In this multiphase structure, breakaway fission gas bubble morphology has developed. The low-temperature $\left(250^{\circ} \mathrm{C}\right)$ sample shown in Fig. 4.30 still largely retains the characteristic bubble-free microstructure of $\mathrm{UAl}_{x}$.

As for the suitability of these alternative compounds as fuel candidates, $\mathrm{U}_{3} \mathrm{Si}$ would behave satisfactorily if the fuel volume fraction in the meat could be kept low enough so that interconnection of fuel particles is prevented throughout the irradiation. Since $\mathrm{U}_{3} \mathrm{Si}$ appears stable at high temperatures, this is a concern only below $\sim 350^{\circ} \mathrm{C}$, where $\mathrm{U}_{3} \mathrm{Si}$ becomes amorphous.

Because $\mathrm{U}_{3} \mathrm{O}_{8}$ and $\mathrm{UAl}_{x}$ are of lower uranium density than are either $\mathrm{U}_{3} \mathrm{Si}$ or $\mathrm{U}_{3} \mathrm{Si}_{2}$, their application would require substantially higher fuel volume fractions in the meat. The breakaway gas bubble behavior of $\mathrm{U}_{3} \mathrm{O}_{8}$ at low temperature and of $\mathrm{UAl}_{\mathrm{x}}$ at high temperature would render this compound less suitable for high-burnup service. 


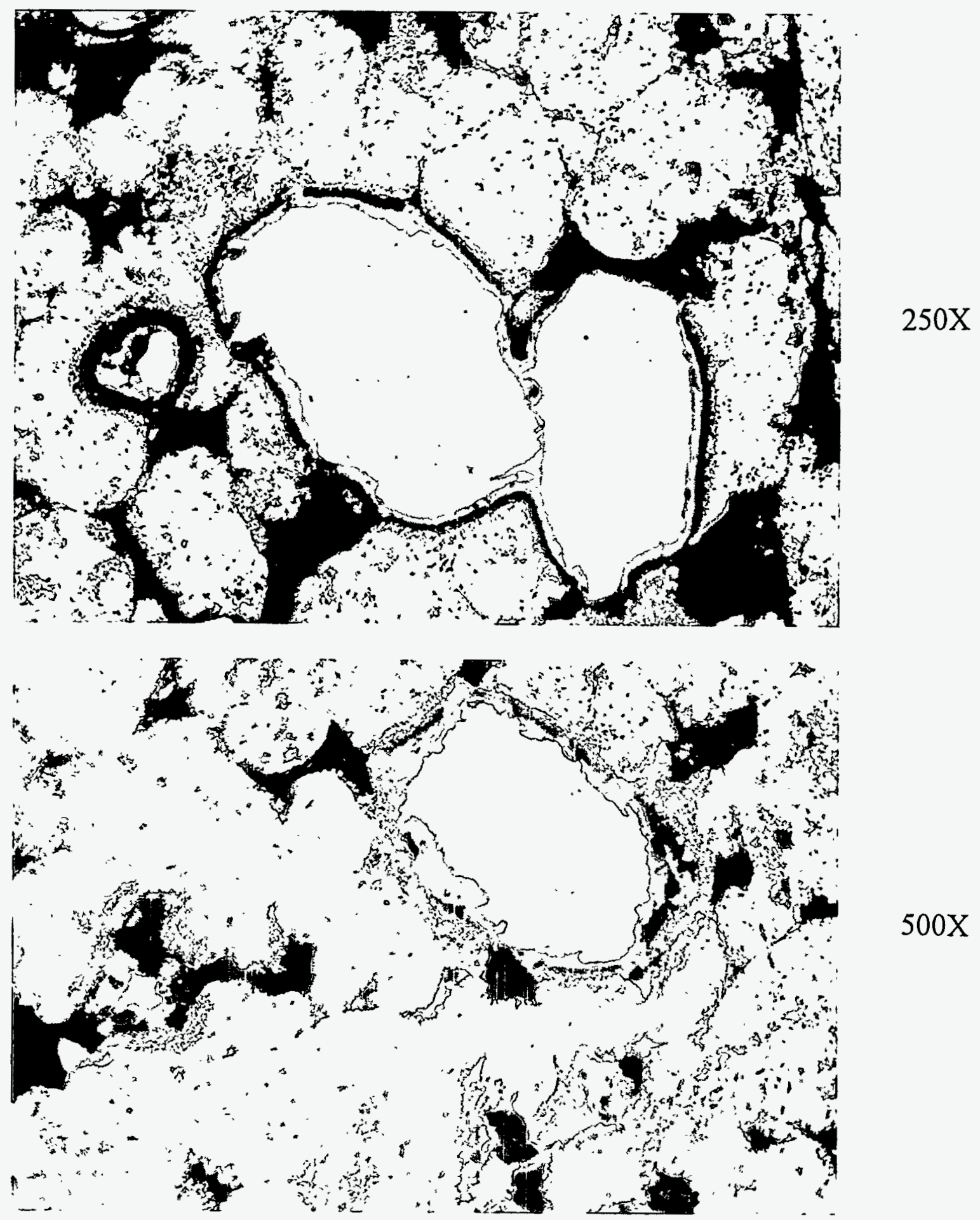

Fig. 4.27. Microstructure of $\mathrm{U}_{3} \mathrm{Si}$ irradiated in the HANS-1 experiment at $375^{\circ} \mathrm{C}$ to $\sim 86 \%$ burnup, showing the absence of large fission gas bubbles. 


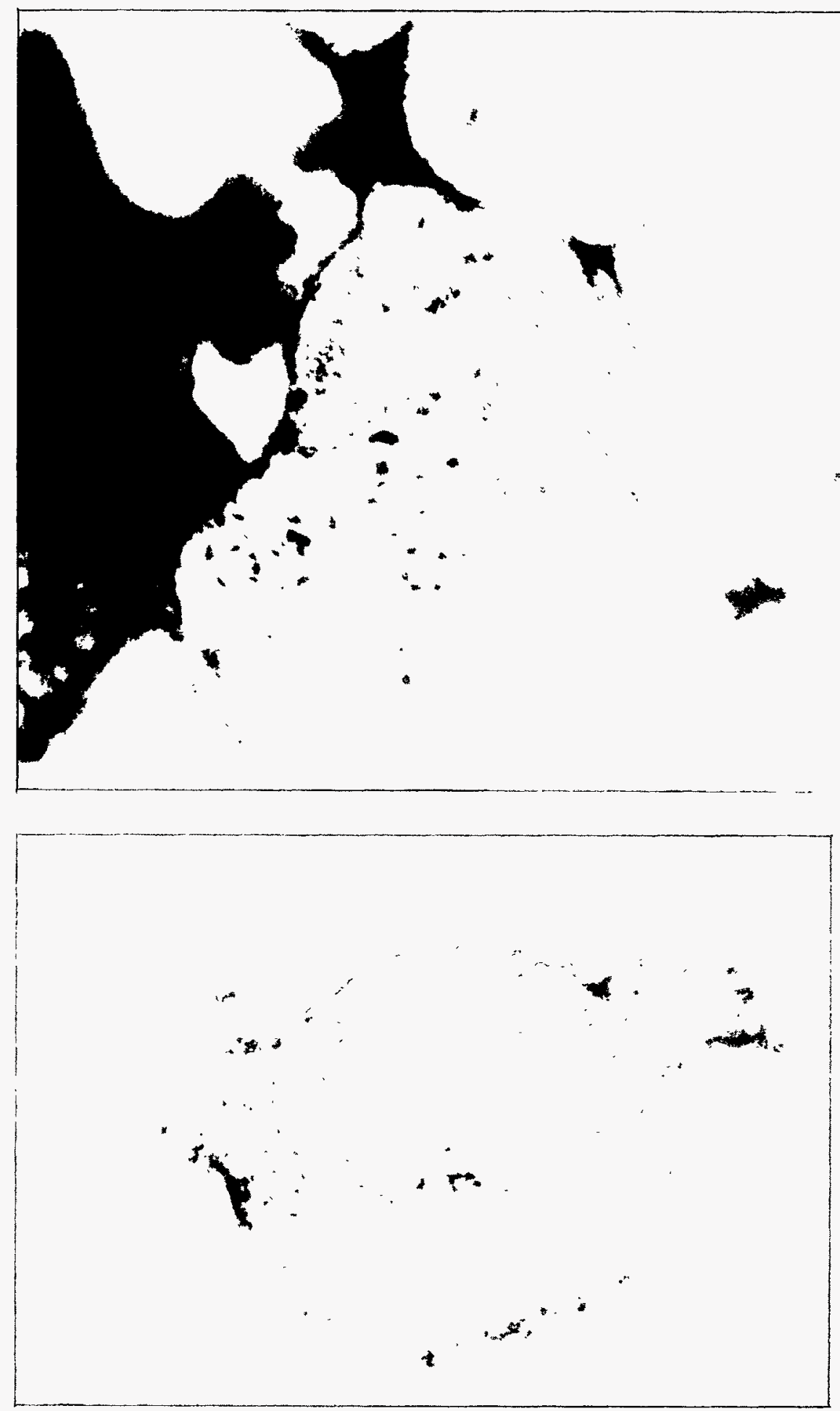

Fig. 4.28. Microstructure of $\mathrm{U}_{3} \mathrm{O}_{8}$ irradiated in the HANS-2 experiment at $425^{\circ} \mathrm{C}$ to $\sim 72 \%$ burnup, showing the absence of large fission gas bubbles. 
3.
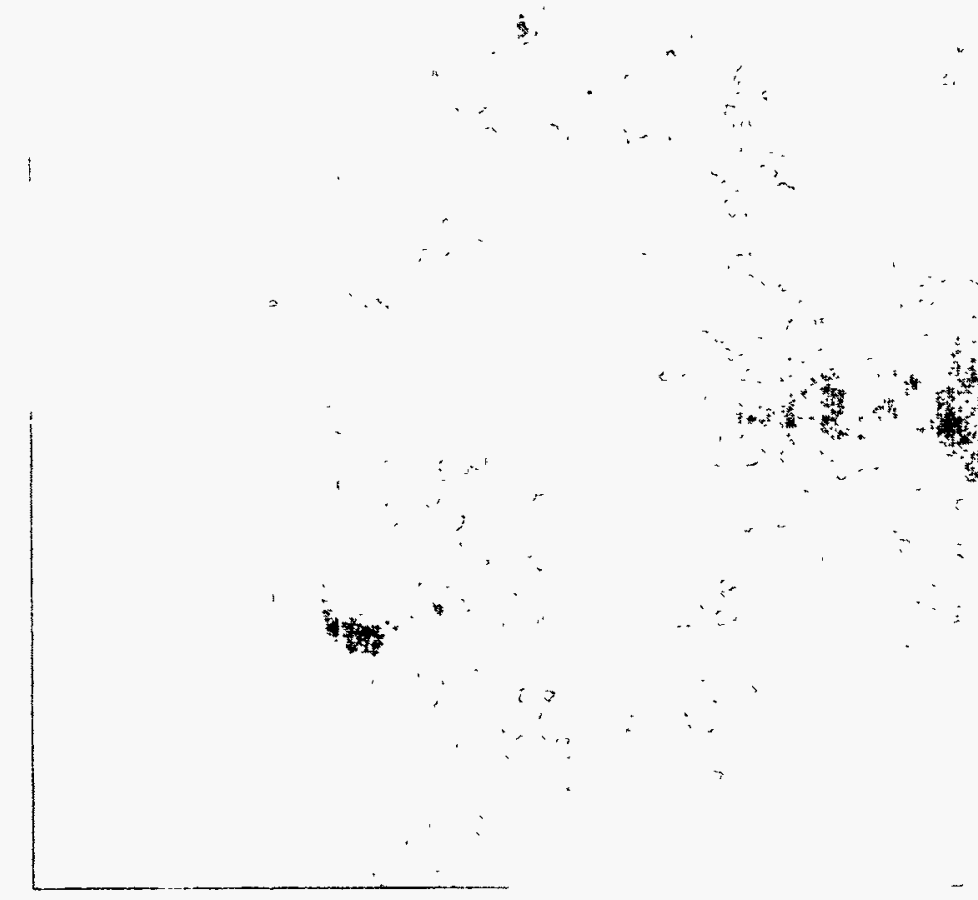


$$
\begin{array}{r}
1-37 \\
4 \\
-1
\end{array}
$$




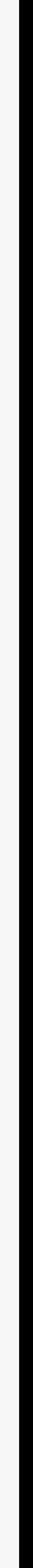




\section{SUMMARY AND CONCLUSIONS}

These capsule tests were highly successful in providing, at a very modest cost relative to plate tests, much information on the prospective performance of these fuels at unprecedented temperatures and fission rates. Of course, plate tests-would eventually be needed (and were planned) to determine swelling rates, structural integrity, etc. under near prototypic conditions to qualify the fuel performance fully. However, these early results on fission gas bubble morphology and chemical interactions were extremely helpful in developing the fuel performance model. All indications are that temperature and burnup values were in the expected range.

Breakaway swelling has been mentioned throughout this report, and all fuel compounds tested appear to be afflicted by it at some combination of temperature and burnup. Breakaway swelling, a phenomenon characterized by rather rapid coarsening of an existing fission gas bubble distribution, is in itself not detrimental to fuel plate behavior. In order to result in excessive deformation (swelling) of a fuel plate, fuel particles in the fuel meat must interlink to allow the formation of large interparticle gas bubbles. Thus, even fuel compounds that exhibit breakaway swelling can be utilized if the individual fuel particles in the meat are prevented from interlinking by keeping the volume fraction of the fuel compound sufficiently low.

Depending on the required fissile loading, low fuel compound volume fractions may be practical only for high-density compounds such as $\mathrm{U}_{3} \mathrm{Si}_{2}$ and $\mathrm{U}_{3} \mathrm{Si}$. Although the HANS-1 and HANS-2 tests have shown that $\mathrm{HEU} \mathrm{U}_{3} \mathrm{Si}_{2}$ at very high burnup exhibits breakaway swelling, the relatively low fuel volume fraction required for the ANS fuel plates ensures that virtually every fuel particle is surrounded by matrix aluminum during the entire irradiation cycle. This condition precludes the aforementioned interlinkage of fission gas bubbles, which is a prerequisite for excessive plate swelling. In addition, aluminum- $\mathrm{U}_{3} \mathrm{Si}_{2}$ interdiffusion forms, around each fuel particle, a shell consisting of an aluminum-type compound that is very stable in swelling behavior. This shell restrains to some extent the swelling of each fuel particle and also prevents interparticle linkage of gas bubbles, where particle contact should occur.

In conclusion, at the volume fraction of $\sim 0.15$ planned for the HEU ANS fuel plates, $\mathrm{U}_{3} \mathrm{Si}_{2}$ would perform well under the full range of operating parameters envisioned. 


\section{REFERENCES}

1. G. L. Copeland et al., Advanced Neutron Source Final Preconceptual Reference Core Design, ORNL/TM-11234, Martin Marietta Energy Systems, Inc., Oak Ridge Natl. Lab., August 1989, p. 6.

2. Safety Evaluation Report Related to the Evaluation of Low-Enriched-Uranium Silicide-Aluminum Dispersion Fuel in Non-Power Reactors, NUREG-1313, U.S. Nuclear Regulatory Commission, July 1988.

3. Conceptual Design Report-Summary, ORNLAANS/INT-34/S1, Martin Marietta Energy Systems, Inc., Oak Ridge Natl. Lab., June 1993.

4. J. L. Snelgrove et al., The Use of $U_{3} S_{2}$ Dispersed in Aluminum in Plate-Type Fuel Elements for Research and Test Reactors, ANL/RERTRTM-11 (October 1987) and, with minor revision, ANLNPR-93/002, Appendix D1 (February 1993), Argonne National Laboratory, Chicago.

5. J. L. Snelgrove, RERTR Program Fuel Testing and Demonstration-An Update, ANL/RERTR/TM-6, Argonne National Laboratory, Chicago, July 1985, pp. 137-145.

6. G. L. Copeland et al., Performance of Low-Enriched $U_{3} S i_{2}$-Aluminum Dispersion Fuel Elements in the Oak Ridge Research Reactor, ANL/RERTR/M-10, Argonne National Laboratory, Chicago, October 1987.

7. J. L. Snelgrove, G. L. Copeland, and G. L. Hofman, "Postirradiation Examination of ORR Demonstration Elements," pp. 151-160 in Reduced Enrichment for Research and Test Reactors-Proceedings of the 12th International Meeting, Berlin, 10-14 September 1989, Forschungszentrum Jülich GmbH, Berlin, 1991.

8. G. L. Hofman, J. Rest, and J. L. Snelgrove, A New Swelling Model and Its Application to Uranium Silicide Research Reactor Fuel, ANL/RERTR/TM-19 Argonne National Laboratory, Chicago, July 1993, pp. 186-96.

9. John S. Nordyke, ed., Lead in the World of Ceramics, American Ceramic Society, Columbus, Ohio, 1994, p.9.

10. J. E. Palentine, "The Development of Silicon Carbide as a Routine Irradiation Temperature Monitor, and Its Calibration in a Thermal Reactor," J. Nucl. Mater. 61, 243-53 (1976).

11. M. J. Kania and A. M. Howard, HTCAP-1 - A Program for Calculating Operating Temperatures in HFIR Target Irradiation Experiments, ORNLTM-7336, Union Carbide Corp., Oak Ridge Natl. Lab., June 1980.

12. K. Farrell, "Response of Aluminum and Its Alloys to Exposure in the High Flux Isotope Reactor," pp. 73-76, in Dimensional Stability and Mechanical Behaviour of Irradiated Metals and Alloys, British Nuclear Energy Society, London, 1983.

13. Z. H. Ismail and H. G. Mohammed, "Effect of Prior History on the Response of Some Commercial Aluminium Alloys to Low Dose Neutron Irradiation," Scr. Metal. 23, 2067-72 (1989). 
14. S. Nazaré, Investigations of Uraniumsilicide-based Dispersion Fuels for the Use of Low Enrichment Uranium (LEU) in Research and Test Reactors, KfK 3372, Kernforschungszentrum Karlsruhe, July 1982.

15. T. C. Wiencek, R. F. Domagala, and H. R. Thresh, Thermal Compatibility Studies of Unirradiated Uranium Silicide Dispersed in Aluminum, ANL/RERTR/TM-6, Argonne National Laboratory, Chicago, July 1985, pp. 61-74.

16. G. L. Garner, K. E. Bogacik, and J. W. Oswood, LEU Silicide Programs at Babcock and Wilcox, ANL/RERTR/TM-9, Argonne National Laboratory, Chicago, May 1988, pp. 80-115.

17. A. E. Dwight, A Study of the Uranium-Aluminum-Silicon System, ANL-82-14,Argonne National Laboratory, Chicago, September 1982.

18. G. L. Hofman, "Fission Gas Bubbles in Uranium-Aluminide Fuels," Nucl. Technol. 77, 110-15 (April 1977).

19. J. Rest, GRASS-SST: A Comprehensive Mechanistic Model for the Prediction of Fission-Gas Behavior in $\mathrm{UO}_{2}$-Base Fuels During Steady-State and Transient Conditions, ANL-78-53, Argonne National Laboratory, Chicago, June 1978.

20. M. L. Bleiberg, R. M. Berman, and B. Lustman, "Effects of High Burn-up on Exide Ceramic Fuels," pp. 319-428 in Radiation Damage in Reactor Materials, International Atomic Energy Agency, Vienna, 1963.

21. J. Rest, "The DART Dispersion Analysis Research Tool: A Mechanistic Model for the Prediction of Fission Product Induced Swelling of Aluminum Dispersion Fuels," to be published at Argonne National Laboratory, Chicago.

22. G. L. Hofman, "Crystal Structure Stability and Fission Gas Swelling in Intermetallic Uranium Compounds," J. Nucl. Mater. 140, 256-63 (1986).

23. G. L Hofman, G. L. Copeland, and J. E. Sanecki, "Microscopic Investigation into the Irradiation Behavior of $\mathrm{U}_{3} \mathrm{O}_{8}-\mathrm{Al}$ Dispersion Fuel, Nucl. Technol. 72, 338-44 (March 1986).

24. M. L. Bleiberg, W. Yeniscavich, and R. G. Gray, Effect of Burnup on Certain Ceramic Fuel Materials, WAPT-T-1274, Westinghouse Bettis Atomic Power Laboratory, Pittsburgh, 1961. 
Appendix A. CHEMICAL ANALYSIS DATA FOR FUEL HOLDER MATERIALS 



\section{$\therefore$ \\ - Information about Polycrystalline Silicon;}

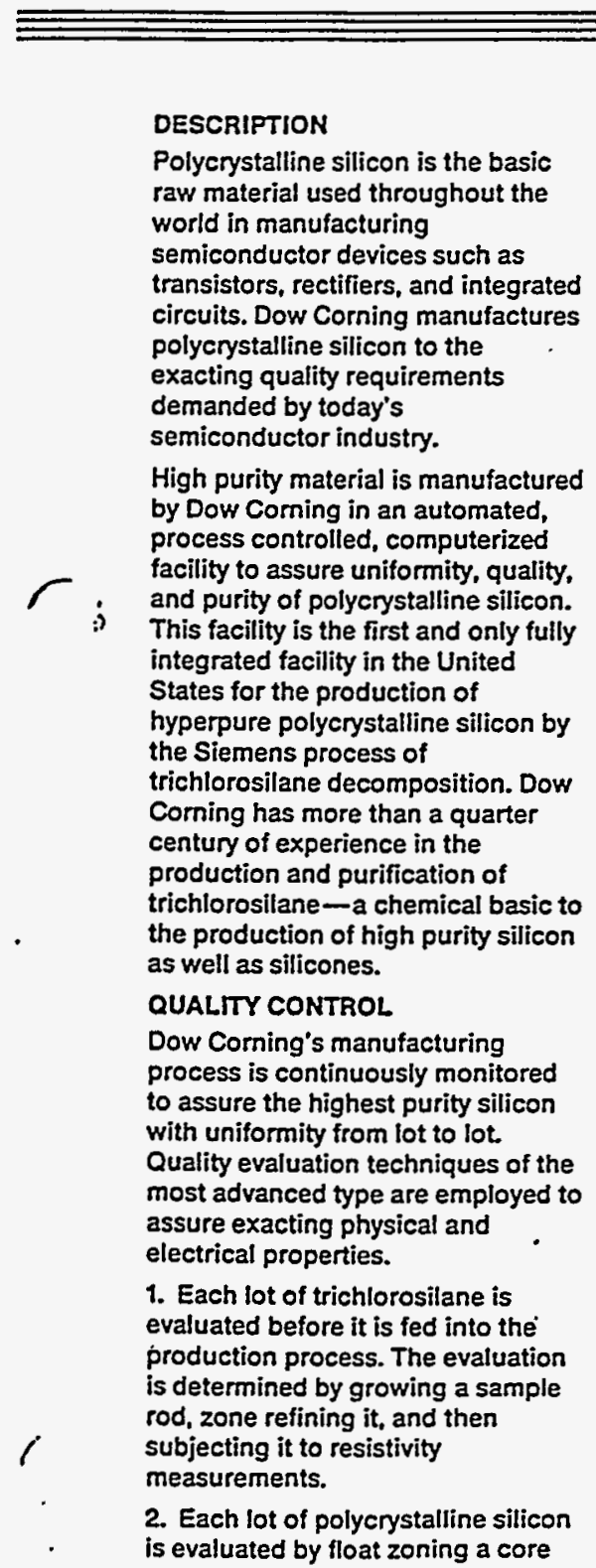

$38.030 \quad 6 / 76$

$8 / 78$ RFo

DOW CORNING:
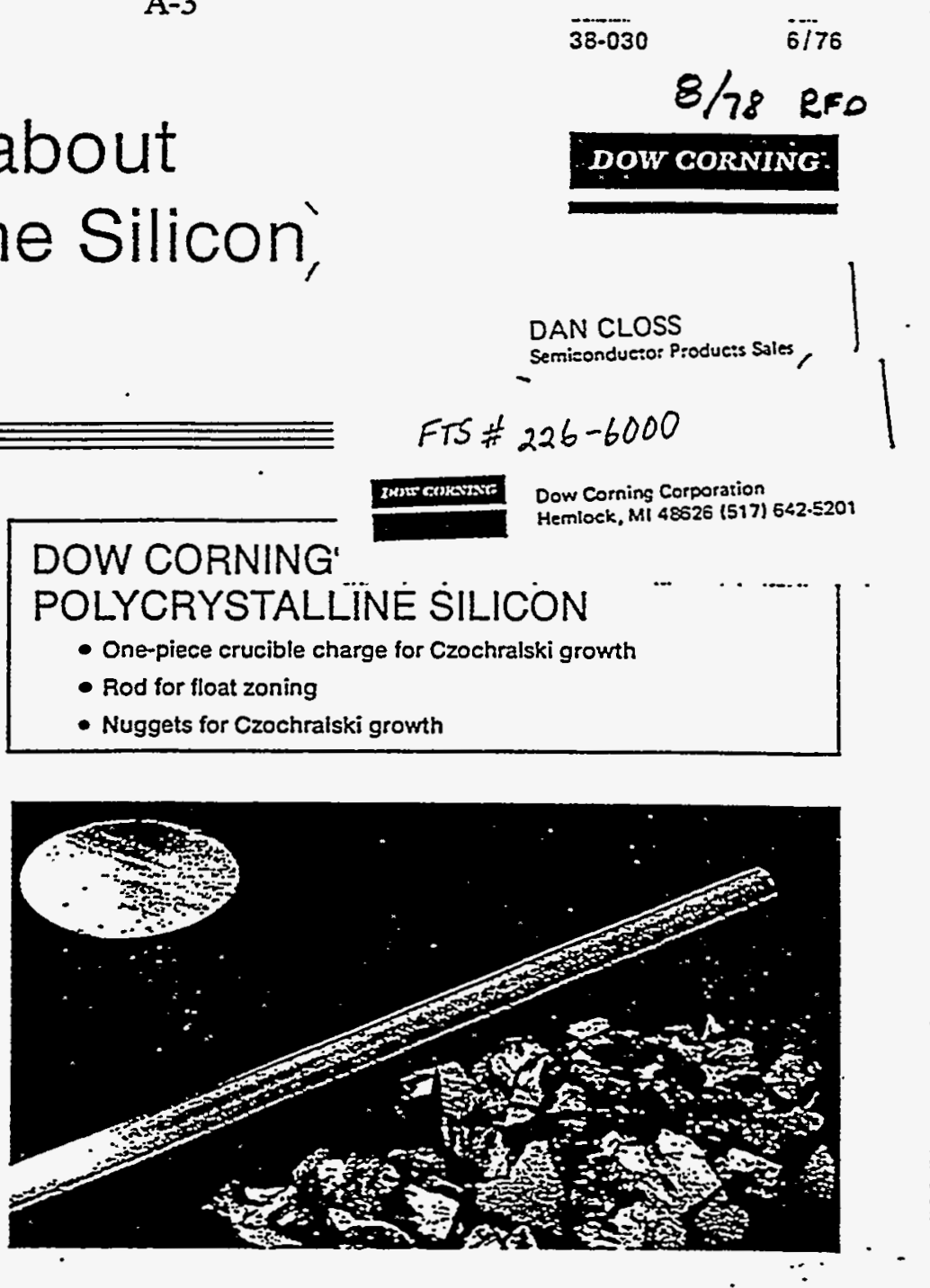

taken from the lot. The core is taken perpendicular to the rod axis to assure that when zone refined in an argon atmosphere, the entire growth area is evaluated. Resistivity measurements are then made on the single crystal rod to determine exact donor or boron impurities. Further zoning in vacuum will remove all impurities except boron. By solving the equation $C_{D}-C_{B}=C_{N E T}$ our Quality Assurasice group can determine total acceptor and donor concentrations in parts per billion - atomic (ppba) where:

$$
\begin{aligned}
& C_{D}=\text { Concentration of donor } \\
& \text { impurities } \\
& C_{B}=\text { Concentration of boron } \\
& \text { impurities }
\end{aligned}
$$

\section{$C_{\text {NET }}=$ Net impurity concentration calculated after the one argon pass.}

3. To measure minute non-doping impurities in the polycrystalline silicon, mass spectrometric analyses, as well as infrared spectrographic analyses, are carried out periodically as a final audit of quality.

In order to further assure the customer that all impurities are within specification limits, standard audit procedures are periodically conducted on all phases of the evaluation procedure. Each shipment is certified to the customer's specification. 


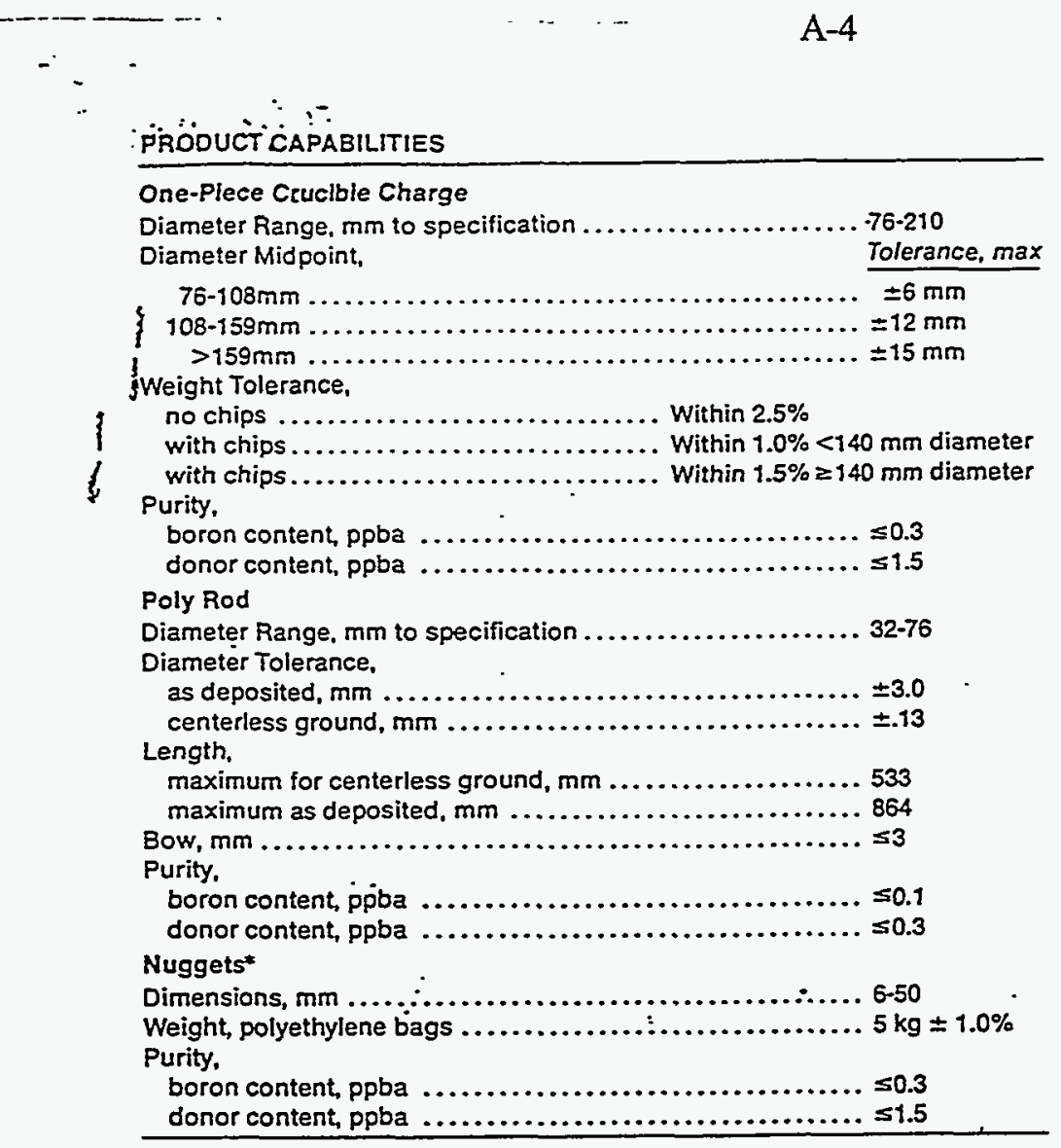

- Uniform, random sizo piecos
In addition to its rigorous manufacturing and quality control procedures, Dow Corning. the world"s largest seller of

polycrystalline silicon, carries on a vigorous research and development effort aimed at improving both product quality and production efficiency.

\section{CLEANING AND PACKAGING}

All polycrystalline silicon products are cleaned using a degreasing and acid etching procedure.

Polycrystalline rods and charges are individually packaged under clean room conditions to prevent surface contamination.

\section{NOTE:}

Dow Coming does nol maintuln

semiconductor product speclallats at all salos othess. For additional intormation ploase contact us at:

Midlend-577-496-5072

Brussels - 20/673.80.60

Los Angetos - 213-570-8227

Miten-2/60.70.35

Munkh-89M4s5

Now York-201.567- 4960

Parts-1/977.0040

Sen Franclseo - 415-964-7744

Toromto-416-635-6116

Windsor, U.K. - T34/57.251

\section{Si USEO FOR}

$U$-Si ALLOYS FOR RERTR \& ANS Programs. No Furtitar Analymeal work Done RFD
The intormation ane data contzinod heroun are basted on information we beliover reliabie. You zhould thoroughly

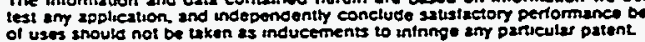

DOW CORNING CORPORATION. MIDLAND, MICHIGAN 48640

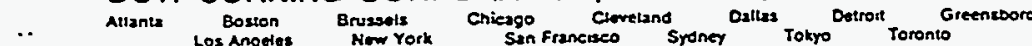

DOW CORNING DaW CORNINC

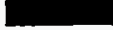




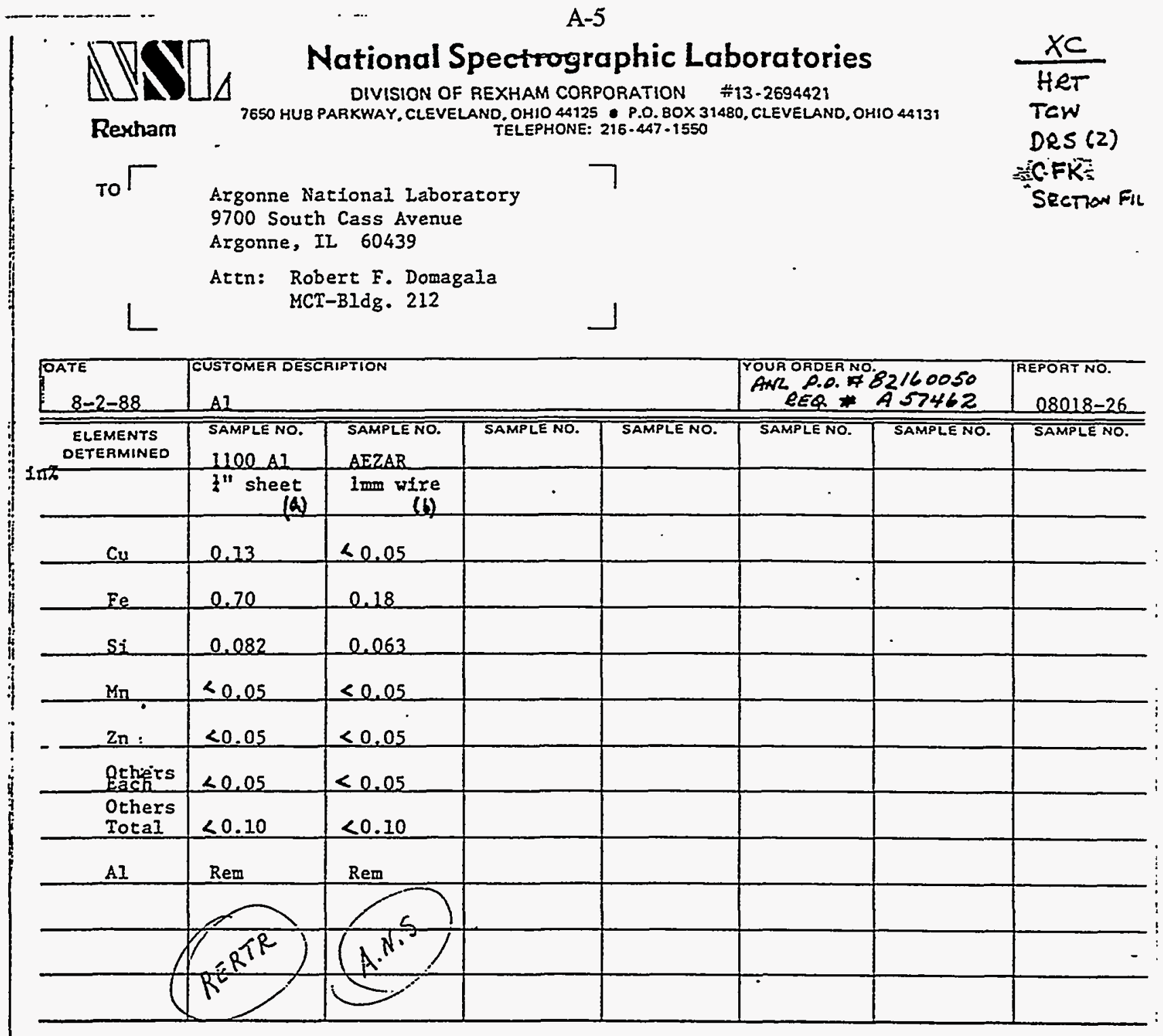

Lab No.

16156-16157 (a) IloO Al SHEET PURCHASED BY TCW

ON C.S. P.R A A HoO49. ReCro AT ANL BLOG 2125 HAP

7-25.88. P. $0 . \% 05$

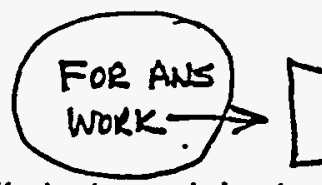

(b) 1 mim pure Al wire purchased fro

Produet * Uncertain Purchased trom Johnsen Mathey AESAR

We certify the above analysis to be the true resuits on the designated samples.

8-8-88: ABONe Al SHICET "Pueg" AL wher

RFO FOL WORK ON RERTE ANS. HAIL

IN H-137. BOTH MUTT SPECS FOR

THER GRADE OF AL.

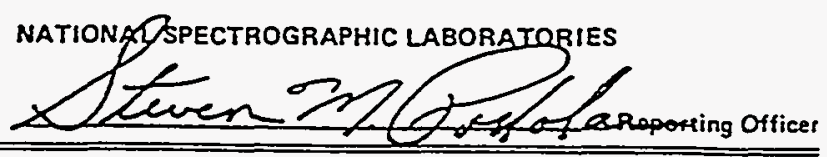

Sworn so and suypeibed before me a Notary Public in and for

the County of Cyytesoga, State of Ohio, this

DAY OF

.19

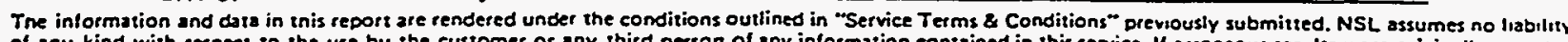
of any kind with respect to the use by the customer of any third person of any information contained in this service. If erroneous results were originally reportec NSL's only liability shall be limited to repeating the analyses without charge to customer or making a relund. No patt of this repor: is to be reprodueed for adver tistng without out consent in writung.

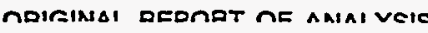


1 ALCAN POTDERS AND PIGMENTS

DIVISION OF ALCAN ALUMINUM CORPORATION

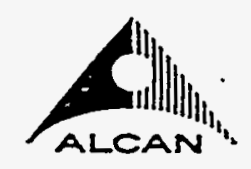

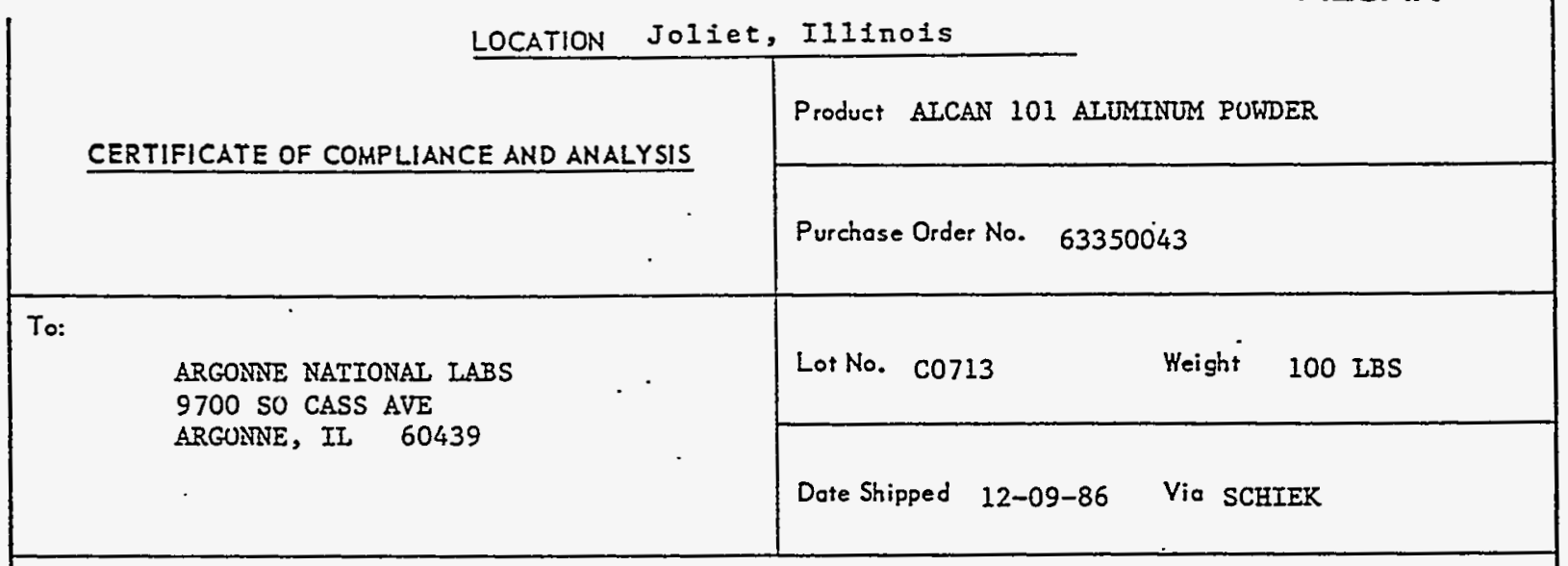

It is further certified that the following is an analysis of the cbove material, covering detailed requirement of applicable specification number ALCAN SPECIFICATIUNS

doied and

List applicable authorized woivers and changes

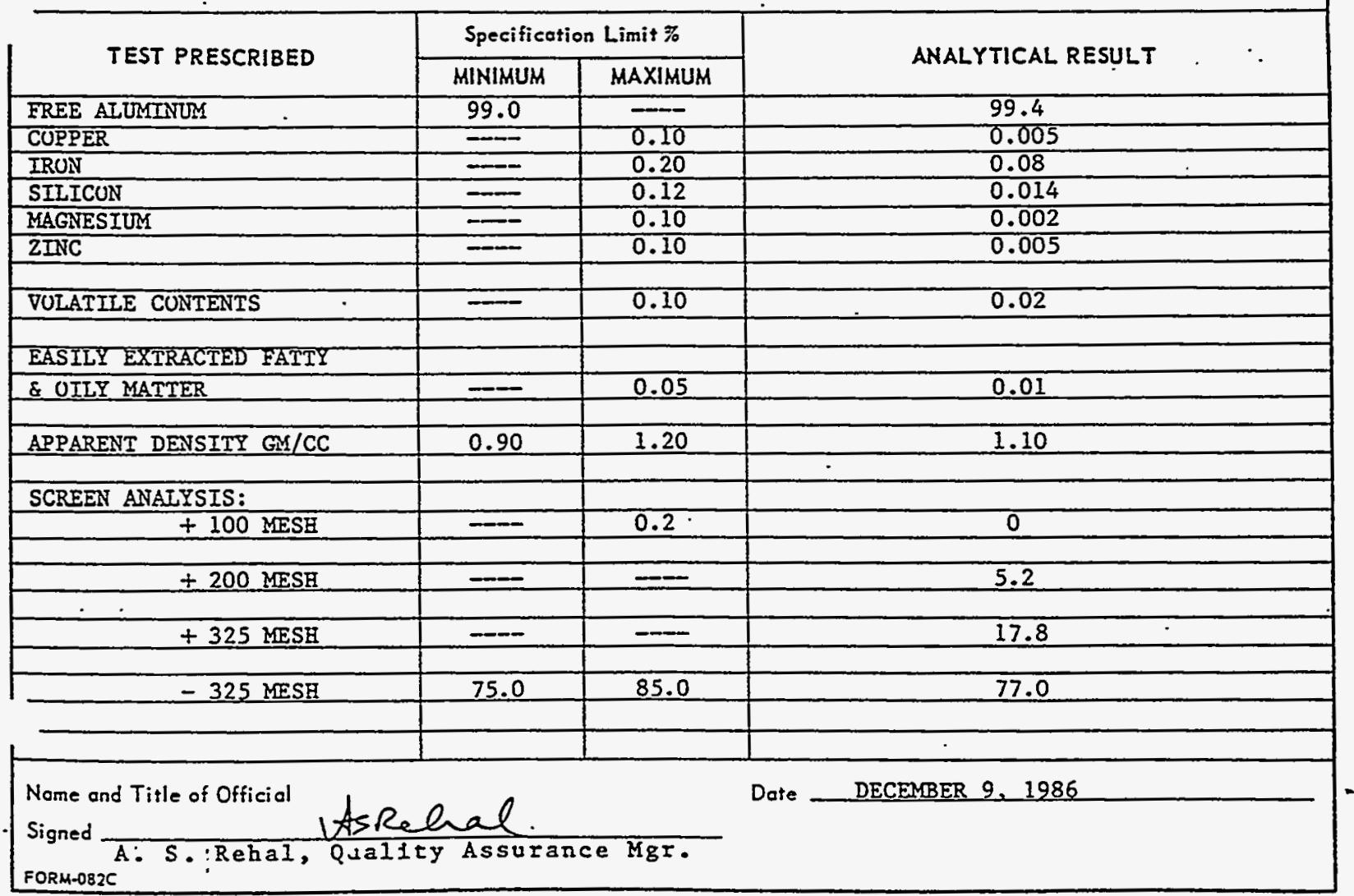


$\mathbb{Q} \mathbb{N}]_{\Delta}$

Rextram

\section{National Spectrographic Laboratories}

DIVISION OF REXHAM' CORPORATION \#13-2694421

7650 HUB PARKWAY, CLEVELANO. OH1O 44125 - P.O. 80X 31480, CLEVELAND. OH1O 44131 TELEPHONE: $216 \cdot 447 \cdot 1550$

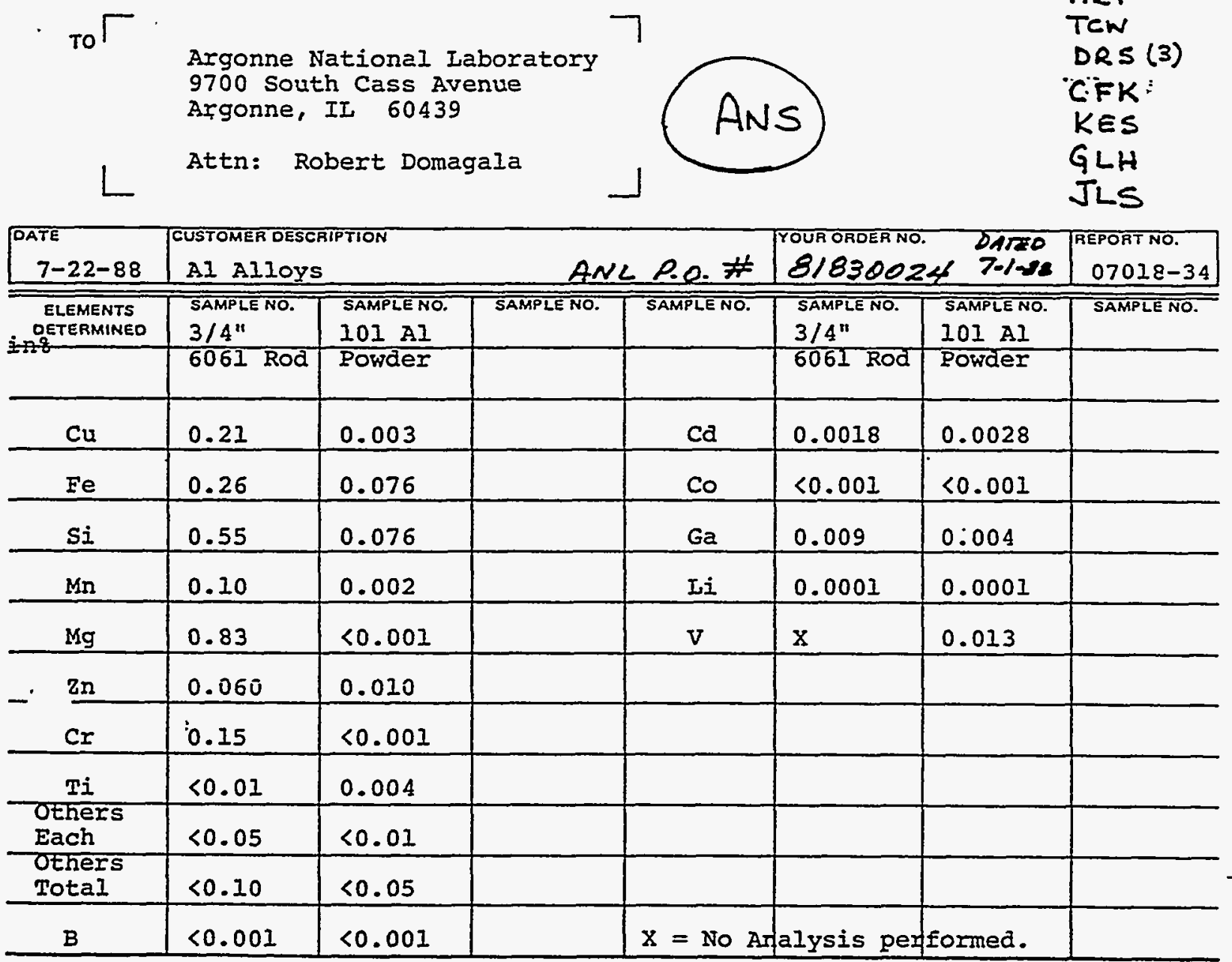

Lab No. 14030-14031

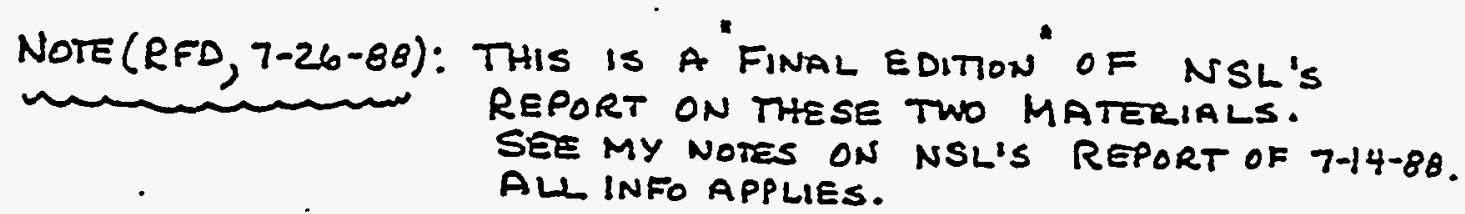

We certify the above analysis to be the true results on the designated samples.

NATIONAL SPECTROGRAPHIC LABORATORIES

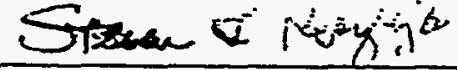

Reporting Otficer

Sm , and wbseribed bofore mo Notary Public in and for

tha cunty of Cuyatiog. Stute of Ohio, this

\section{DAY OF}

.19

The information and data in this report are rendered under the conditions outlined in "Service Terms \& Conditions" previously submizted. NSL assumes no liability of any kind with rexpect to the use by the customer or any third person of any information contained in this service. If erroneous results were originally reported NSL's only liability shall be limited to repeating the analysis without chorge to customer or making a refund. No part of this report is to be reproduced for adver tiung without our consent in writing.

notrthit beonot ne AMA vol 
SPECTROCHEMICAL ANALYSIS REPORT

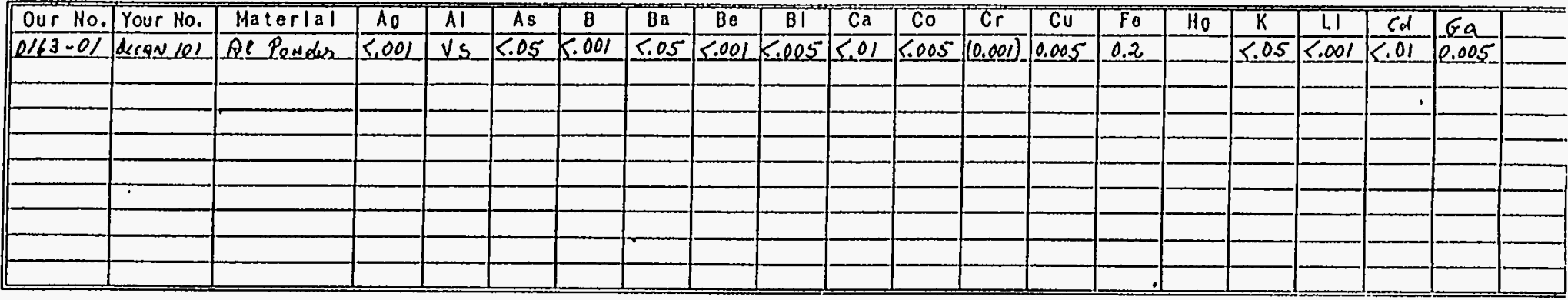

87.

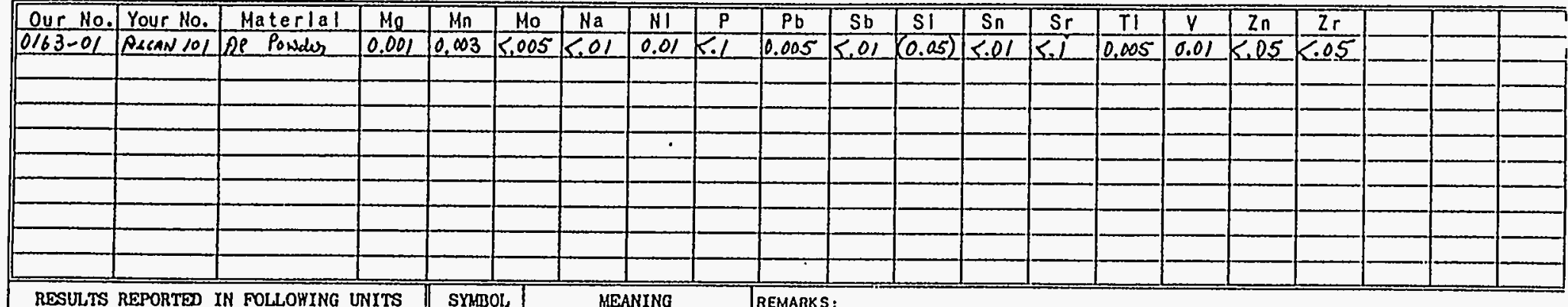

RESULTS REPORTED IN FOLLOHING UNITS

$\square$ parts ner million

$\square$ per cent

$\square$ mlcrograms per ml.

$\square$ micrograms in total sarnile $\square$

\section{ESTIMATED ACCURACY OF RESULTS} $\nabla$ order of magnitude

$\square$ eactor of two

$\square$ _ \% of awount present

\begin{tabular}{|c|}
\hline Plate No. \\
\hline By: $\quad$ S.0. Nuell \\
\hline $2-11-87$ \\
\hline
\end{tabular}

CHM-61 17.7

\section{symol.} L less than

\begin{tabular}{|l|l|}
\hline$G$ & 8roator than \\
\hline & elowont not Investigated \\
\hline
\end{tabular}

olement not detected

- Interference

(1) accuracy uncertain $?$ presence uncertain SNROQ MEANING APPROX. CONC. \begin{tabular}{c|c|c|}
\hline VS & yery strong & $100 \%$ to $10 \%$ \\
\hline
\end{tabular} S 1 strong M moderato 18 to $0.1 \%$

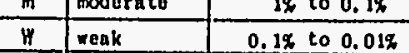
T treco 0.12 to $0.01 \%$

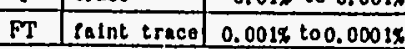

Alcan 101 al Powdore pupchasto ON ANL PIO. \#63350043 (RECVO 12.86)

As-RECVD, SIEVEO-100 MESH

(Not VAcuUM AnNenLtro)

THIS is a NOW SUPpLY or 101 Al PowBur 读RFO'
Subal tted By:_R.F. Domajala

Location:__ $\quad 212$ Dnte Recelved: $1-19-8 z$ Reports To: $\sim$

T.C. Wienced, P.R.Srhmith, ACd office

XC: TCW, DRS, H.I3TCFILE HRT 


\section{ANALYTICAL CHEMISTRY LABORATORY \\ Argonne National Laboratory \\ Argonne, IL 60439}

REPORT OF ANALYTICAL RESULTS

Sample Material: ATcan 101 Al Powder

Date Received: $\quad 1 / 19 / 87$

Submitted by:

R. Domagala

Date Reported: $\quad 4 / 9 / 87$

\begin{tabular}{|c|c|c|}
\hline Your Number & Our Number & Al iquot $\mathrm{Wt} ., \mathrm{g}$ \\
\hline $\begin{array}{l}\text { ALCAN } 101 \\
\text { As-Rec'd. } \\
\text { Al Powder }\end{array}$ & $87-4027$ & $\begin{array}{ccc}0.0939 & -- & 2185 \\
0.1006 & -- & \frac{2050}{2118} \pm 95 \\
\text { Aver. } \pm \text { s.d. } & & \cdot \\
0.0584 & 60.6 & \cdot \\
0.1318 & 57.5 & \\
0.0568 & \underline{46.8} & \end{array}$ \\
\hline & & 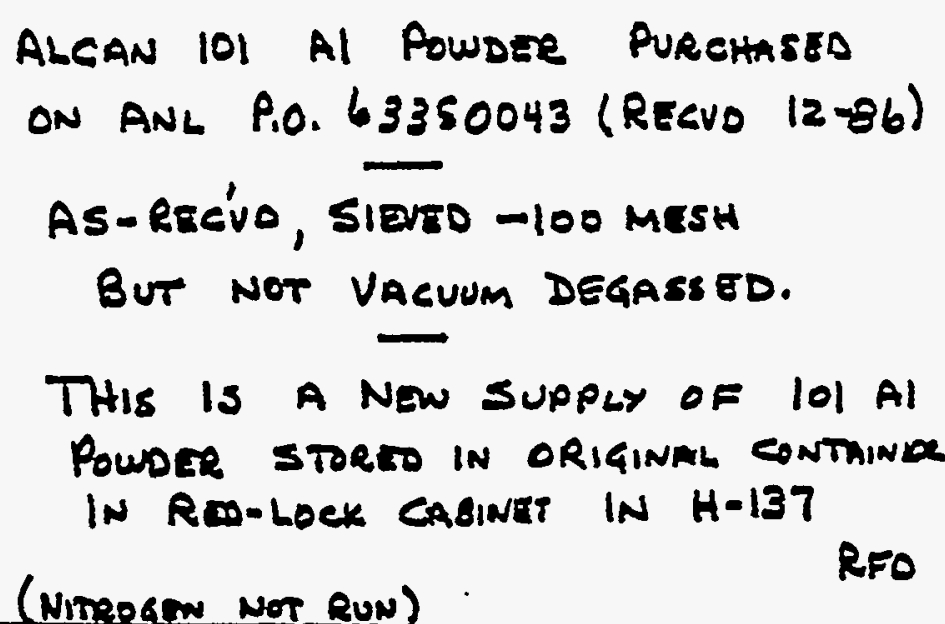 \\
\hline
\end{tabular}

Copies To: R. Domagala

T. Wiencek

D. Schmitt

D. Green

Ivaa

cutes (10s)

R. Heinrich (2)

E. Streets
Analyst(s): $\quad$ E. Streets

XC: HRT, TCW, DRS, H-137 FILE (2 CQPIG)

RFO CHEW PLE 


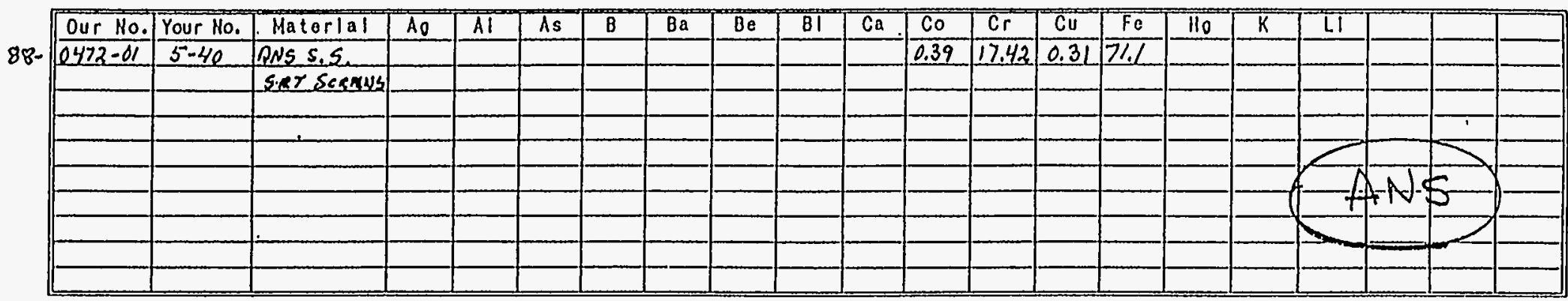




ARGONNE NATIONAL LABORATORY

9700 South Coss Avenue

Argonne, Allinois 60439

REPORT ON CHEMIGL ANALYSIS

Dote Received: $\quad 9 / 16 / 83$

Somple: Uranium Silicides

Source: R. Domagala

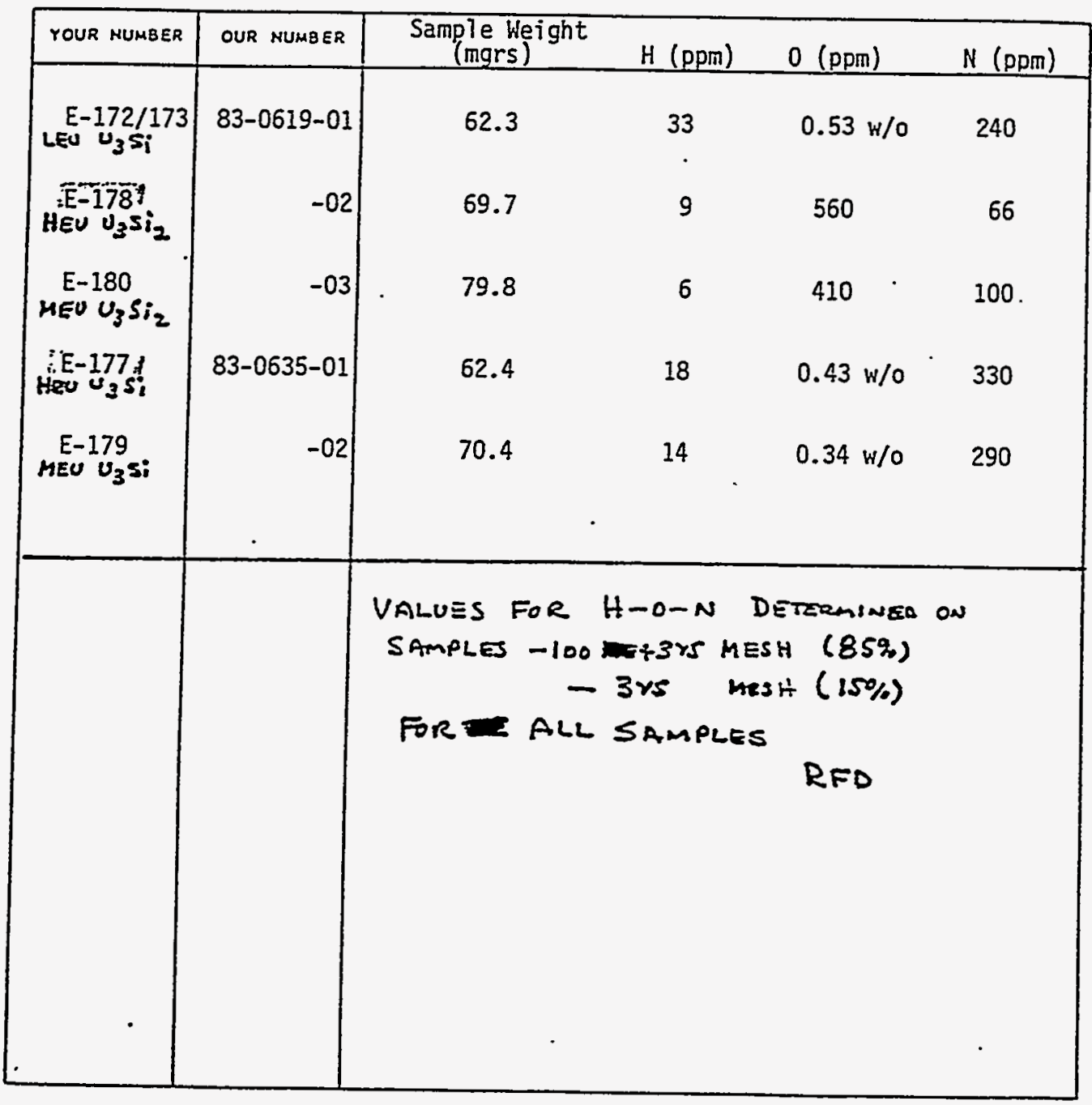

Reported by: M. Homa

Copies to:

Æ. Domaga 7a

T. Wiencek

H. Thresh

K. Jensen

CHM.17A (7.67)

D. Graczyk
Dote: $\quad 10 / 3 / 83^{\circ}$

Anolys: M. Homa
R. Heinrich File

/vaa 


\section{ARGONNE NATIONAL LABORATORY}

9700 South Cass Arenue

Argonne, Illinois 60439

\section{REPORT ON CHEMICAL ANALYSIS \\ Doie Received: 9/1/83}

Somple: $\quad U_{3} \mathrm{Si}$ and $\mathrm{U}_{3} \mathrm{Si}_{2}$

Sourca: R. Domagala

\begin{tabular}{|c|c|c|c|c|}
\hline YOUR NUMBER & OUR NUHBER & U Isotopic, Wt. \% & Total U, : & Si, Wt. : \\
\hline $\begin{array}{l}E-172 / 173 \\
U_{3} S i \\
L E U\end{array}$ & $83-0619-01$ & $\begin{array}{cc}220 & 234-0.1120 \pm .0005 \\
=.022 \% & 235-19.833 \pm .010 \\
& \cdot \dot{2}=0.1382 \pm .0005 \\
& 238-79.917 \pm .011\end{array}$ & $\begin{array}{r}A-95.435 \\
B-95.427 \\
95.431 \\
\pm 0.050\end{array}$ & $\begin{array}{l}3.875 \\
3.89_{0}+3.883 \\
\pm 0.008\end{array}$ \\
\hline $\begin{array}{l}\mathrm{EE}-178 \\
\mathrm{U}_{3} \mathrm{SI}_{2} \\
\mathrm{HEV}\end{array}$ & -02 & $\begin{array}{l}234-1.0590 \pm .001 \\
N_{A} \\
235-92.951 \pm .005 \\
236-0.2420 \pm .0005 \\
238-5.748 \pm .003\end{array}$ & $\begin{array}{r}A-92.347 \\
B-92.288 \\
92.317 \\
\pm 0.050\end{array}$ & $\begin{array}{l}7.48_{6} \\
7.39_{2} \\
\pm 0.05\end{array}$ \\
\hline $\begin{array}{l}E-180 \\
U_{3} \mathrm{Si}_{2} \\
\text { MEU. }\end{array}$ & -03 & $\begin{array}{ll}N_{A} & 234-0.3168 \pm .0005 \\
& 235-40.109 \pm .010 \\
& 236-0.4140 \pm .0005 \\
& 238-59.160 \pm .011\end{array}$ & $\begin{array}{r}A-92.291 \\
B-\frac{92.300}{92.295} \\
\pm 0.050\end{array}$ & $\begin{array}{r}7.469 \\
7.495 \\
\pm 0.013\end{array}$ \\
\hline & & $\begin{array}{l}\text { Andiyses above conducted on } P \\
\text { samples submitted to ACL. } \\
\text { Powdes were } 85 \%-100+325 \mu \\
15 \%-3 \gamma 5 \text { Mesh } \\
\text { See alse spectrographic analy }\end{array}$ & $\begin{array}{l}\omega d e r \\
\text { \& \& } H-O-N\end{array}$ & $\left\{\begin{array}{l}h s e s \\
R F D\end{array}\right.$ \\
\hline Reported by: : & E. Callis & Datc: $\quad 9 / 26 / 83$ & $x c-\frac{H e}{\pi}$ & \\
\hline 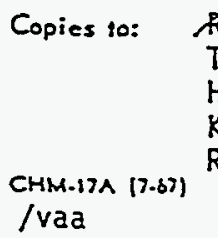 & $\begin{array}{l}\text { R. Domagala } \\
\text { T. Hiencek } \\
\text { H. Thresh } \\
\text { K. Jensen } \\
\text { R. Heinrich }\end{array}$ & $\begin{array}{ll}\text { Andyst: } & \text { I. Fox } \\
& \text { E. Callis } \\
& \text { E. Rauh } \\
& \text { K. Jensen }\end{array}$ & $\begin{array}{l}H \\
\pi\end{array}$ & $\begin{array}{l}\text { ING FILE } \\
\text {. }\end{array}$ \\
\hline
\end{tabular}




\section{A-13}

ARGONNE NATIONAL LABORATORY

9700 South Cess Arenuo

Asgonne, Allinois 60439

REPORT ON CHEMICAL ANALYSIS

Dote Received: $\quad$ \&/30/83

Somple: $\quad U_{3} S i$

Source: R. Domagala

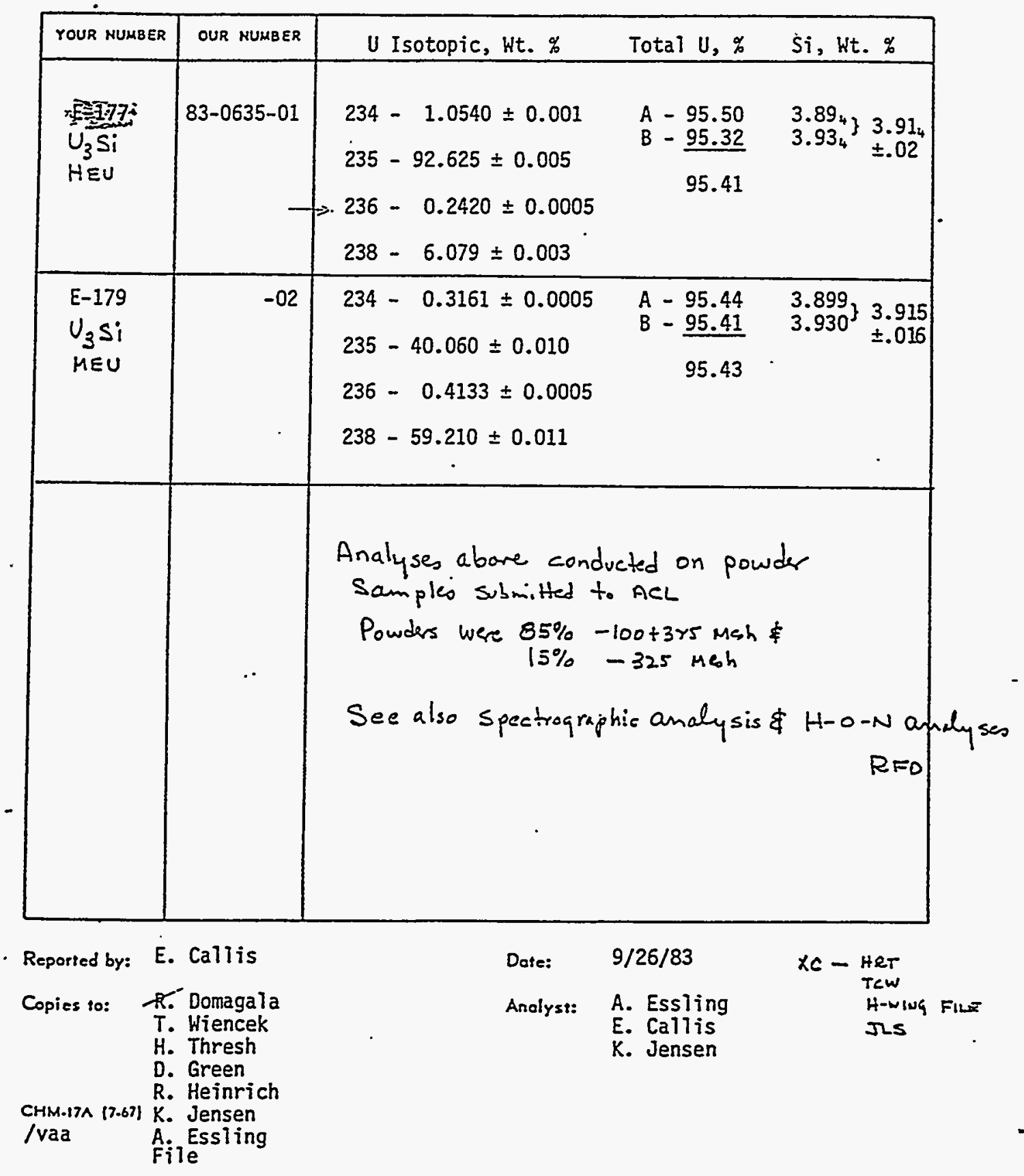


$83-0,35=01,-02$

SPECTROCHEMIC/ INALYSIS REPORT

\begin{tabular}{|c|c|c|c|c|c|c|c|c|c|c|c|c|c|c|c|c|c|c|c|c|}
\hline Jur Ho. & Your No. & Materlal & $\mathrm{AO}_{0}$ & AI & As & $B$ & $8 \mathrm{a}$ & $B C$ & Bi & $\mathrm{Ca}$ & Co & $\mathrm{Cr}$ & $\mathrm{Cu}$ & $\mathrm{Fc}$ & 110 & $K$ & 1.1 & 6.4 & $G a^{*}$ & col \\
\hline 319417 & $E 177$ & $1,1-5 i$ & $<1$ & .1 & & & 1.4 & 53 & & 510 & 33 & 5 & 132 & 911 & & $\angle .90$ & $\overline{5.5}$ & 380 & $\leq 1$ & $<1$ \\
\hline 50 & 18179 & - & 4 & 2 & & & 51 & 4 & & 10 & 20 & 20 & 10 & 158 & & 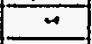 & 4 & 110 & $=$ & $n$ \\
\hline & & & & & - & & & 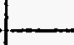 & - & & & & & & & & & & 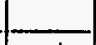 & \\
\hline & & & & & & & & & & & & & & & & & & & -1 & \\
\hline & & & & 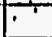 & & & & & & & & & & & & & & & & \\
\hline & & $\therefore$ & & . & & & & & & & & & & & & & & & & \\
\hline & & & & $\therefore$ & & & & & & & & & & & & & & & & \\
\hline & & & & & & & & & & & & & & & & & & & . & \\
\hline & & & & & & & & & & & & & & & & & & & & \\
\hline
\end{tabular}

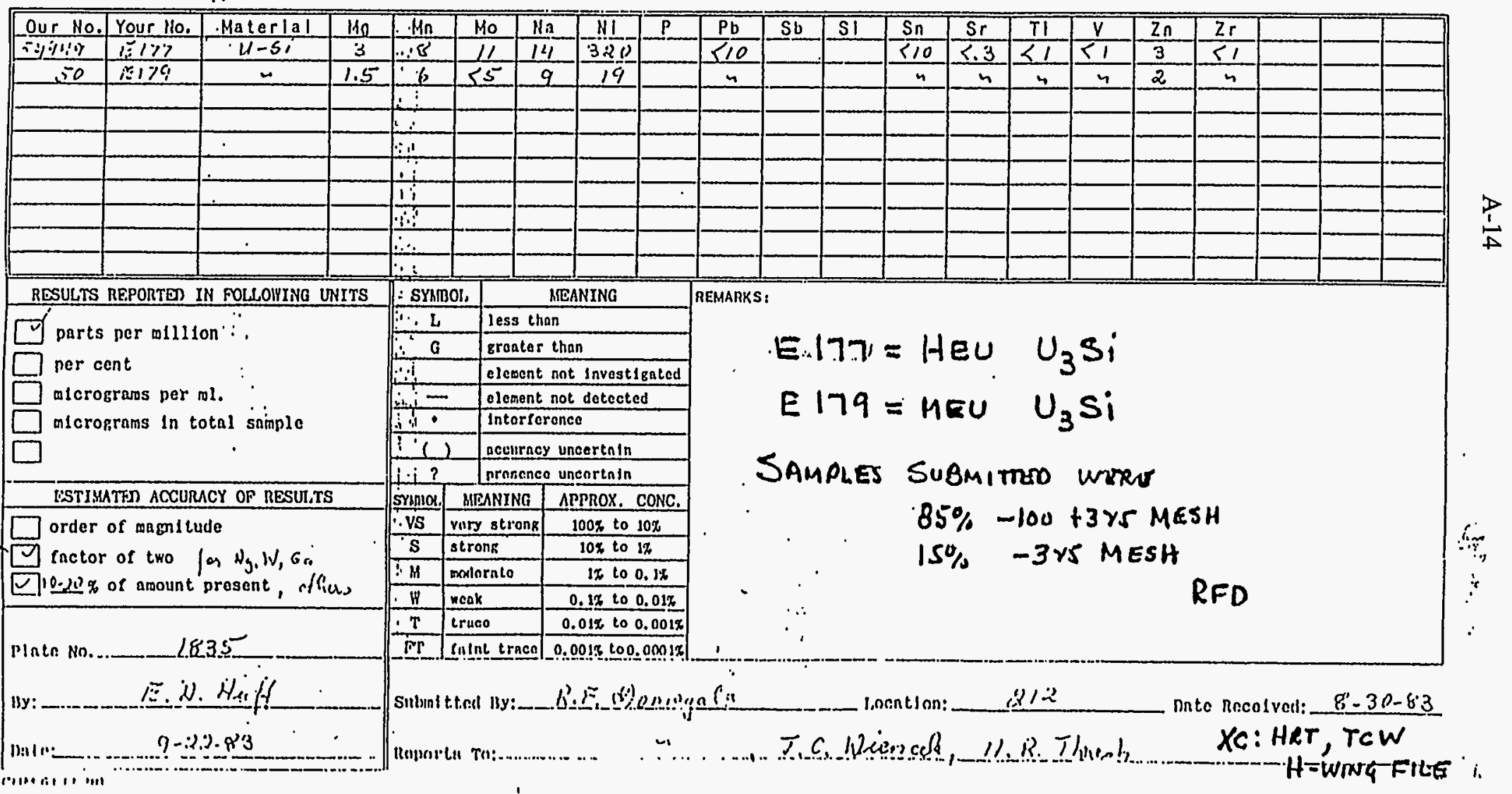
, 


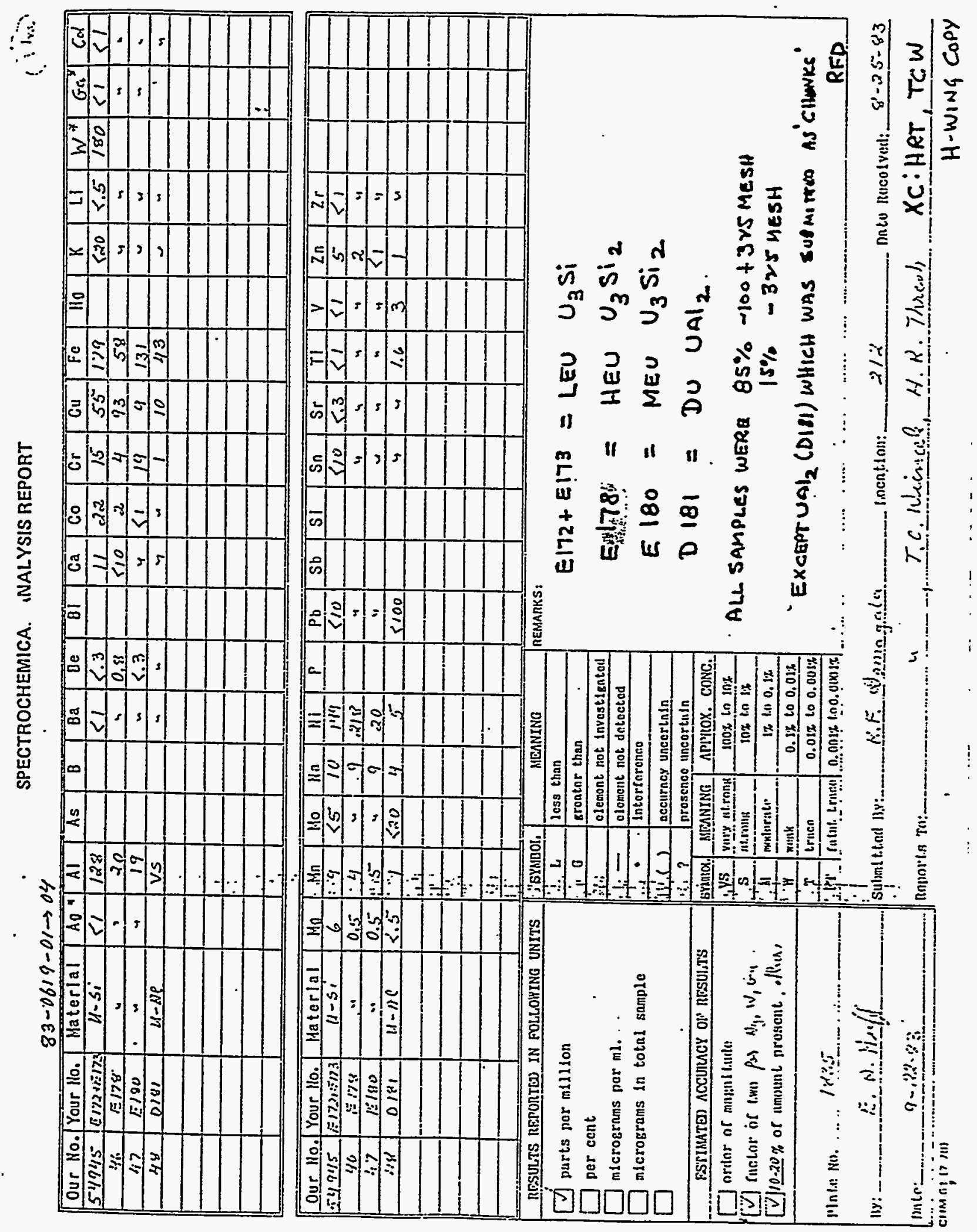




\section{ANALYTICAL CHEMISTRY LABORATORY \\ Argonne National Laboratory \\ Argonne, IL 60439 \\ For ANS \\ FANS (= HANS)}

REPORT OF ANALYTICAL RESULTS
Sample Material:
$\mathrm{UAT}_{2}$
Date Received:
$7 / 17 / 89$
Submitted by:
R. Domagala
Date Reported: $7 / 28 / 89$

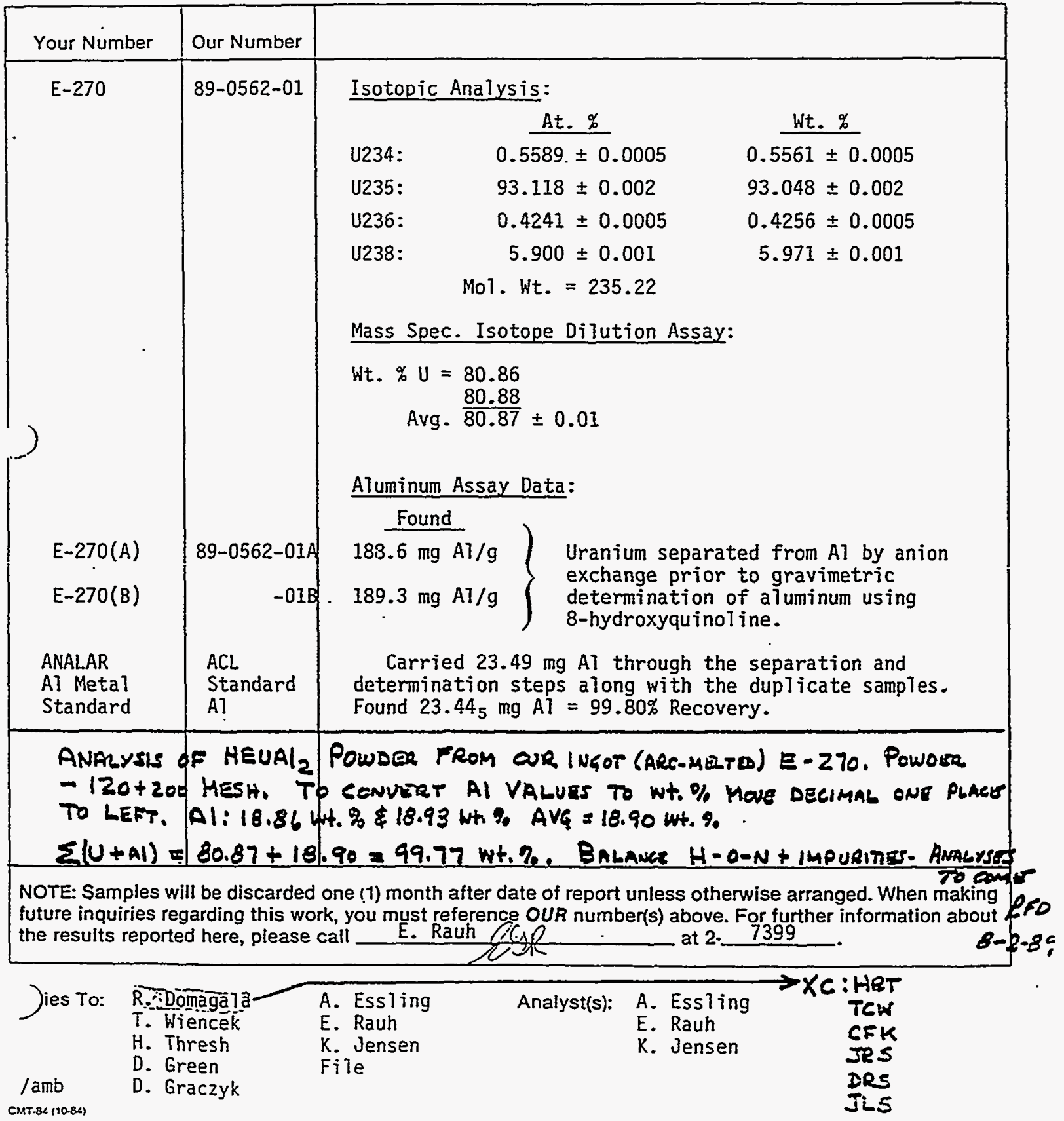




\section{ANALYTICAL CHEMISTRY LABORATORY Argonne National Laboratory Argonne, IL 60439}

REPORT OF ANALYTICAL RESULTS

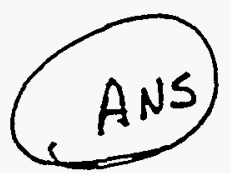

Date Received: $\quad 7 / 18 / 89$

Date Reported: 10/7/89

Submitted by:

R. Domagala

Nitrogen, ppm

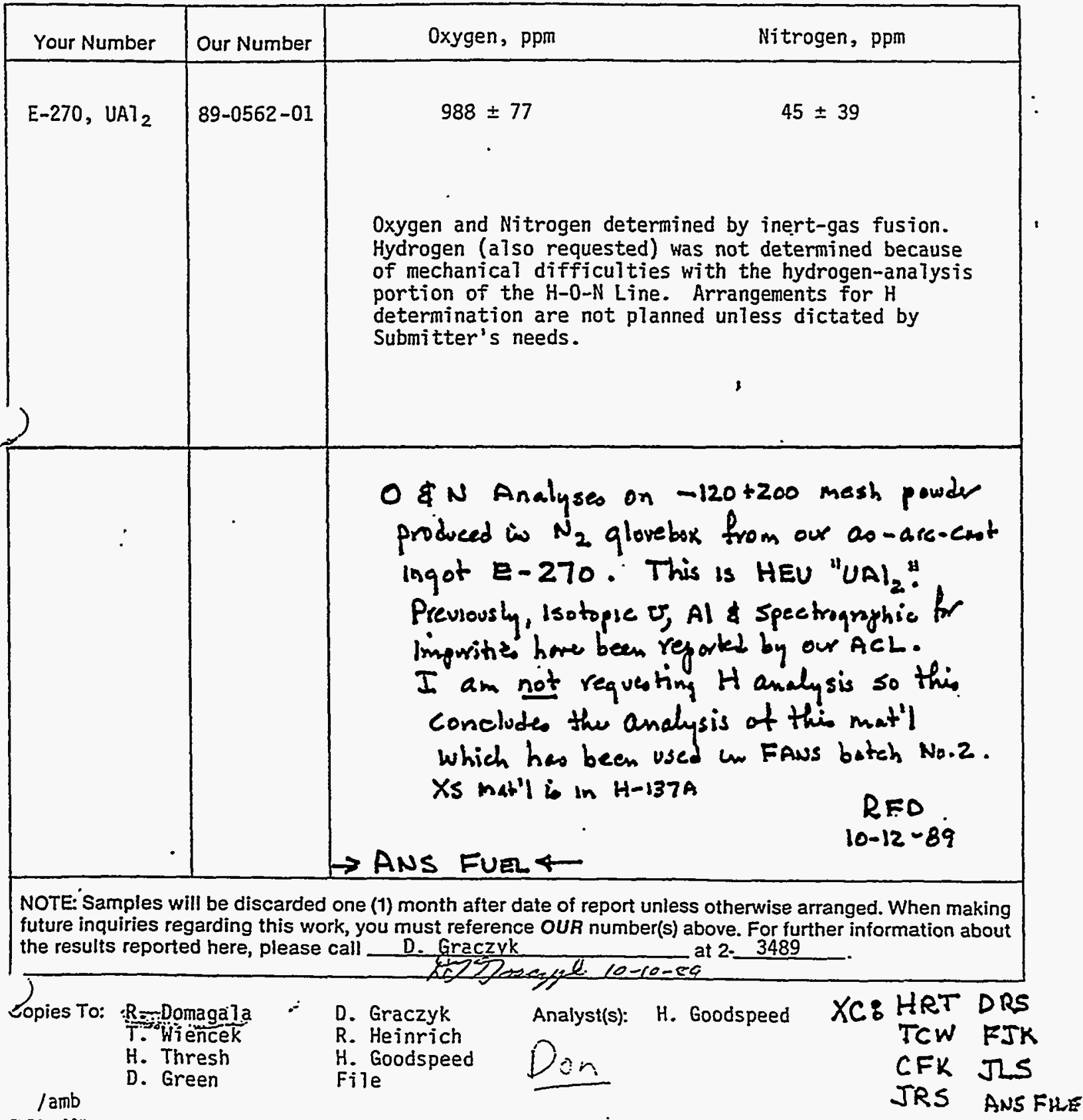




\section{ICP-SPECTROCHEMTEAL ANALYSIS REPORT $U A I_{2}$}

SPEC NO. 56268

\begin{tabular}{|c|c|c|c|c|c|c|c|c|c|c|c|c|c|c|c|c|c|c|c|c|}
\hline Our No. & Your No. & Matorlal & $A_{0}$ & AI & As & 8 & $\mathrm{Ba}$ & 80 & 81 & $\mathrm{Ca}$ & Co & $c r$ & Cu & $\mathrm{Fe}$ & $\mathrm{Ho}_{0}$ & $K$ & 1.1 & d & & \\
\hline 0562.01 & 5.270 & $U-A P$ & & $\sqrt{5}$ & & $(\langle 10)$ & 52 & 21 & & II & 55 & $\pi$ & 13 & 88 & & 520 & 51 & $<2$ & & \\
\hline & & & & & & & & & & & & & & & & & & & & \\
\hline & & & & & & & & & & & & & & & & & & & & \\
\hline & & & & & & & & & & & & & & & & & & & & \\
\hline & & & & & & & & & & & & & & & & & & & & \\
\hline & & & & & & & & & & & & & & & & & & & & \\
\hline & & & & & & & & & & & & & & & & & & & & \\
\hline & & & & & & & & & & & & & & & & & & & & \\
\hline & & & & & & & & & & & & & & & & & & & & \\
\hline & & & & & & & & & & & & & & & & & & & & \\
\hline
\end{tabular}

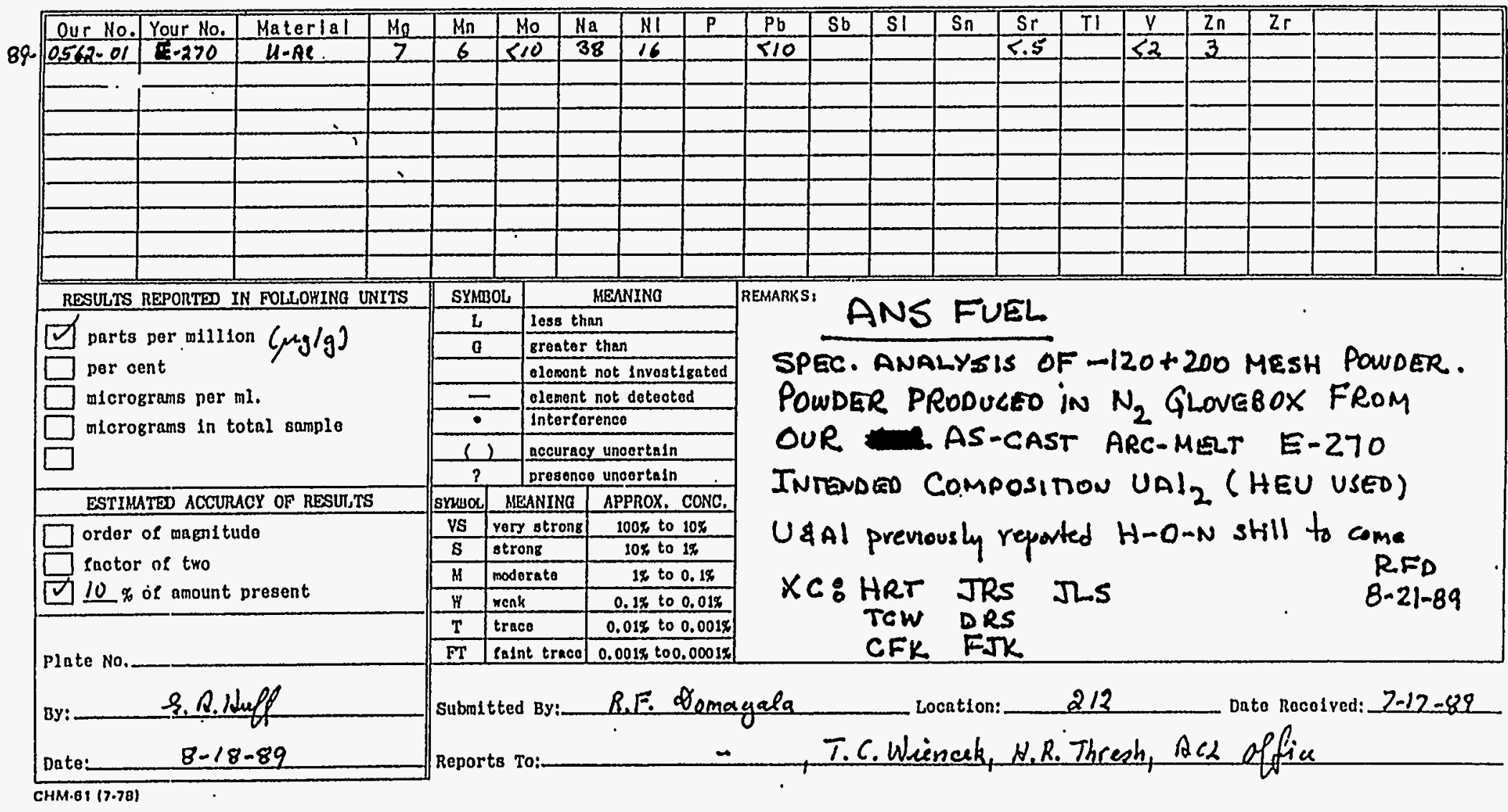


. . .

Babcock \&Wilcox Naval Nuclear Fuet Division Lynchburz Virginis
RAW MATERIAL \& STRUCTURAL RELEASE NPNOCA

Distibution

O.C. Audit \& Release

O.C. Foreman Rease (i)

Pitg. Foren

Prod. Control

John \& Lovie

Accountability

(1)
(11
(1)
(2) Fuel Plare Only
(11)

$7-21-89$

Contract/sob No. C29000/13

B\&W certifies that the supplies listed hereon conform to all contract requirements, including all applicable statistical requirements, and that substantiating data are on file.

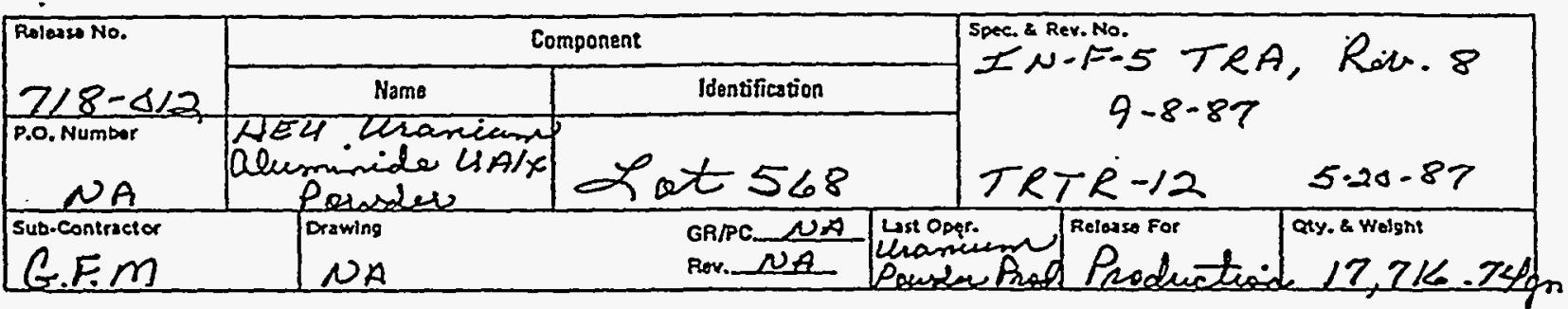

Aermarks:

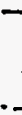

Waiver: NONE

)

signed 0.c. Brenda Drablett Dat 7-14.89 
ESW-NNFD

RTRFE- CII

LOT NUMEEK 568 FUWDER FHYSICAL TEST ANALYSIS
OE/O1/ES

NFN $710^{\circ}$
NFN-QCL-E35 REUISION

APPARENT DENSITY

FULL CLIP 149.43

EMPTY CUP-081.45

POWDER WT $=67.98 \times .04=2.72 \mathrm{GM} / \mathrm{CC}$

SIEVE TEST RUN NO. 1 START WT $=100.00$

MATERIAL TYFE UALX-HEU

RUN No. 1

FLOW RATE FIUN No. 1

27.70 SEC $\times 1.005=27.84$ SEC

$0.00 / 100.00=0.00 \%$ LogS

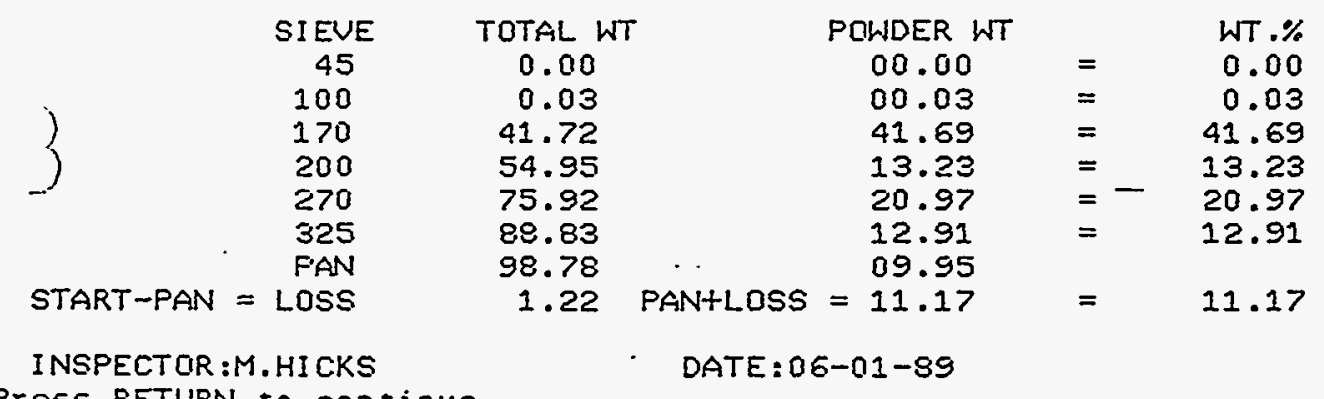




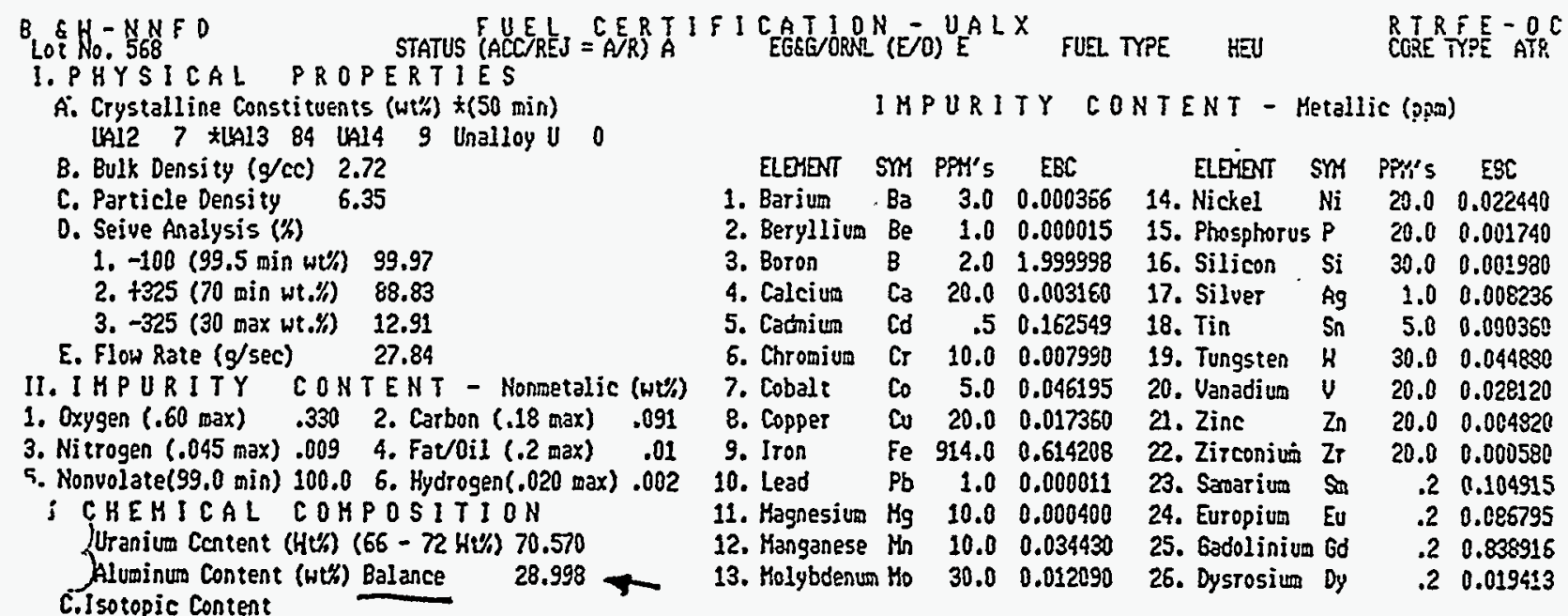

U-234 (1.2 (Univ .5) max wt\% U) 1.019 U-235 (92-94 (Univ 19.55-19.95)wU\% U) 93.057

U-236 (.7 (Univ 1.) max w4s U) 0.402 U-238 (5.05-7.05 (Univ Bal.) w\% U) 5.522

Total EBC Content (max $30 \mathrm{ppm})$

$4.06 ! 987$

Press RETURN to continue 


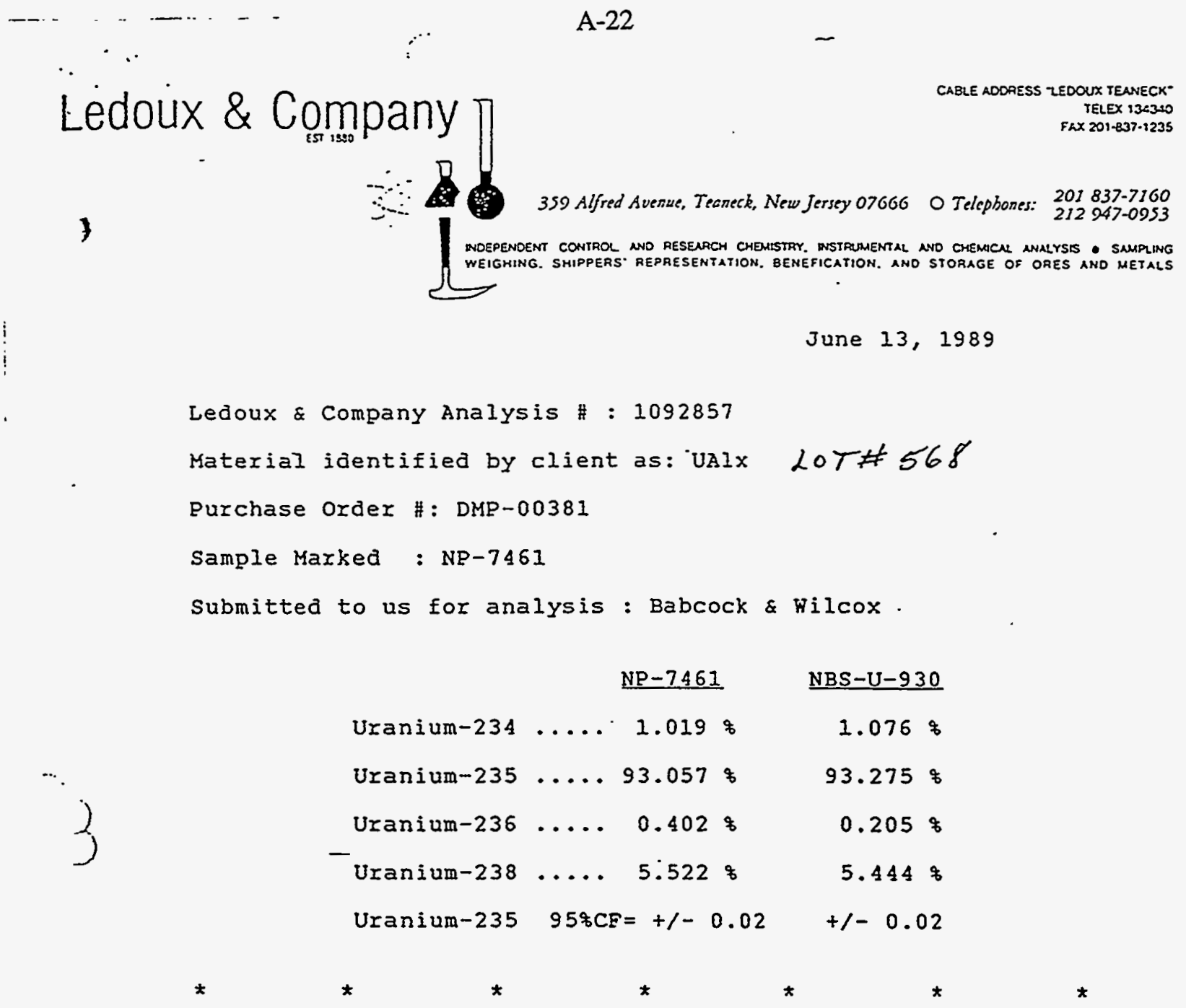

Invoice \& 2 to : Babcock \& Hilcox Company

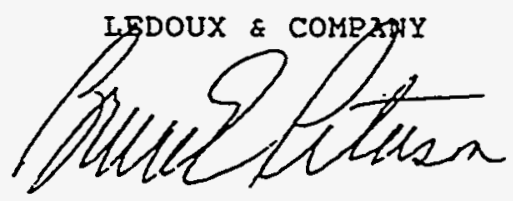

NO VIARRANTY IS EXTENDED IN RESPECT TO SERVICES PROVIDED BY LEDOUX \& COMPANY IPLEASE SEE REVERSE SIDEI 
Ledoux \& Company Analysis \#: 1092857

Material identified by client as: UAIx LoT 568

Purchase order : DMP-00381

sample.marked : NP-7461

submitted to us for analysis by : Babcock \& Wilcox Co.

$j$

\begin{tabular}{|c|c|c|}
\hline arium & 3 & ppm \\
\hline erylizum .. & $<1$ & pm \\
\hline oron ...... & 5 & \\
\hline ium $\ldots$ & & m \\
\hline ium ... & $<$ & $\mathrm{ppm}$ \\
\hline on .... & & pm \\
\hline omium. & 10 & ppm \\
\hline It $\ldots \ldots$ & $<$ & ppm \\
\hline pper ...... & & ppm \\
\hline prosium. & $<0.2$ & pDm \\
\hline gium ... & & ppm \\
\hline nium & & ppm \\
\hline 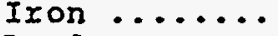 & 914 & ppm \\
\hline$d \ldots \ldots$ & & ppm \\
\hline gnesium . & $<10$ & ppm \\
\hline inganese & 10 & ppm \\
\hline ybdenum .. & 30 & $\mathrm{ppm}$ \\
\hline iel ...... & 20 & ppm \\
\hline ogen .... & 87 & ppm \\
\hline phorous & $<20$ & ppm \\
\hline rium ... & $<0.2$ & ppm \\
\hline con $\ldots$ & 30 & ppm \\
\hline er. & $<1$ & ppm \\
\hline$\cdots$ & 5 & מpg \\
\hline gsten .... & 30 & pqu \\
\hline dium .... & 20 & pm \\
\hline$\because \ldots$ & $<20$ & pm \\
\hline & & \\
\hline
\end{tabular}

\section{*} * $\star$

Invoice \& 2 to: Babcock \& Filcox Company

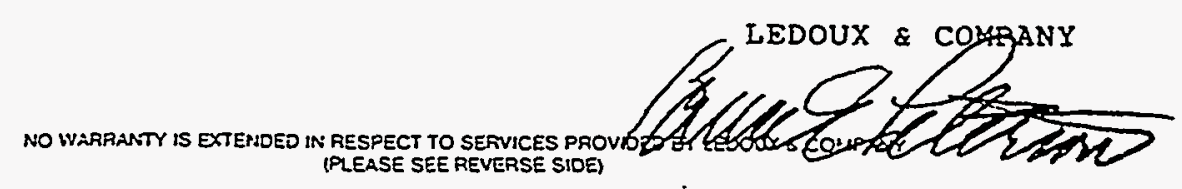


LRC-124

$\because$ - RADIOANALYTICAL

CHEMISTRY LABORATORY

ANALYSIS REQUEST

\section{Babcök \& Wilcox}

a McDermott company

LYNCHBURG RESEARCH CENTER

)

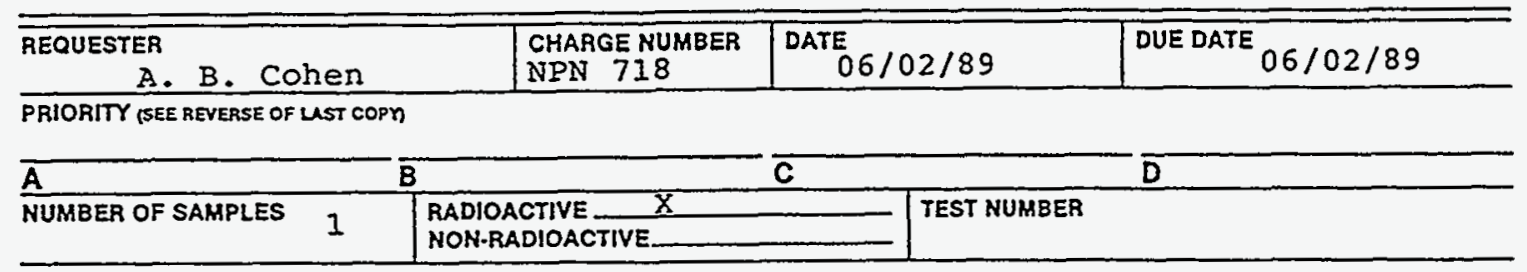

SAMPLE NUMBERS

$893=$ Lot $\frac{\pi}{\$} 568$

SPECIAL HANDLING AND DISPOSAL PROCEDURES

RETURN ALI MATERTAL

DESCRIPTION OF SAMPLES AND DESIRED ANALYSIS NNCLUE MUXIMUM DESIRED ERROR LMTSS

UALX for Phase Analysis

RESULTS

$\begin{array}{lrr}\text { UAL2 } & 78 & 68 \\ \text { UAL3 } & 848 & 858 \\ \text { UAL4 } & 98 & 98 \\ & & \\ \text { Unalloyed U not detected }\end{array}$

\begin{tabular}{|c|c|c|c|c|c|}
\hline $\begin{array}{l}\text { ANALYZED BY } \\
\text { EM } \\
\end{array}$ & & $\begin{array}{r}\text { DATE } \\
06 / 02 / 89\end{array}$ & APPROVED BY & & DATE \\
\hline REOUEST NUMBER & $015 \overline{35}$ & LABORATORY BOOK & NUMBER & PAGE & 38 \\
\hline
\end{tabular}

Mis form consiste of:

Origlnal - Luboratory copy

Censory - Rosults copy

PInk - Inter-Laboratory copy

Goldentod - Roquestor cosy 


\begin{tabular}{|c|c|c|c|}
\hline \multirow{2}{*}{ 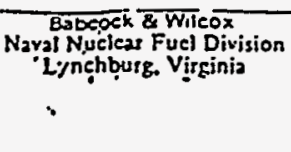 } & $\begin{array}{l}\text { OUALT': } \\
\text { CONTK... }\end{array}$ & $\begin{array}{cl}\text { C. } & \text { JISTRY } \\
\text { LA. } & \text { IATORY }\end{array}$ & $\begin{array}{l}\text { PAGE } \frac{1}{2} \text { OF } \frac{1}{1} \\
\text { DATE } 2-23-87\end{array}$ \\
\hline & \multicolumn{2}{|c|}{ CHEMISTRY ANALYSIS } & Q2-103 Rev. 2 \\
\hline
\end{tabular}

o: B. Triplett \#61

\begin{tabular}{|c|c|c|c|c|c|c|c|}
\hline$\overline{\text { Sat }}$ & No. & Iisted Below & Log No. & Iisted below & Material Tyose & vALX & Dare $07-13-89$ \\
\hline
\end{tabular}

NPN-718

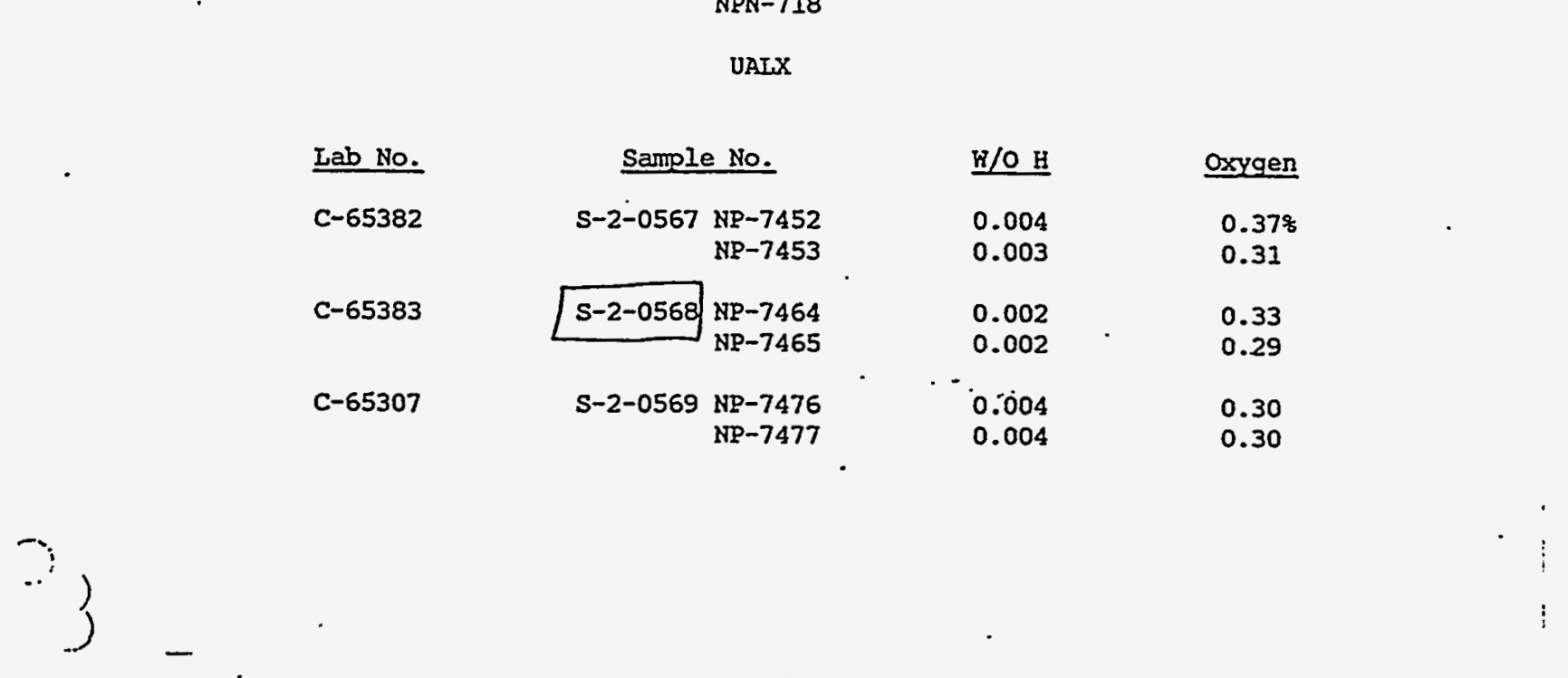

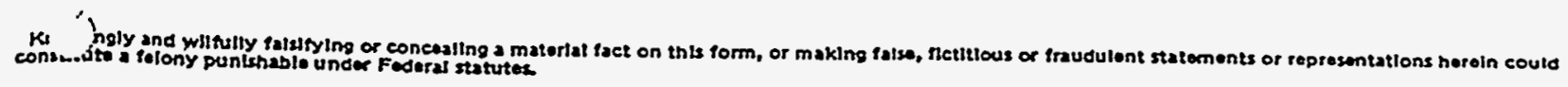

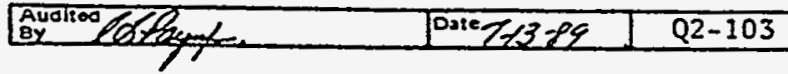




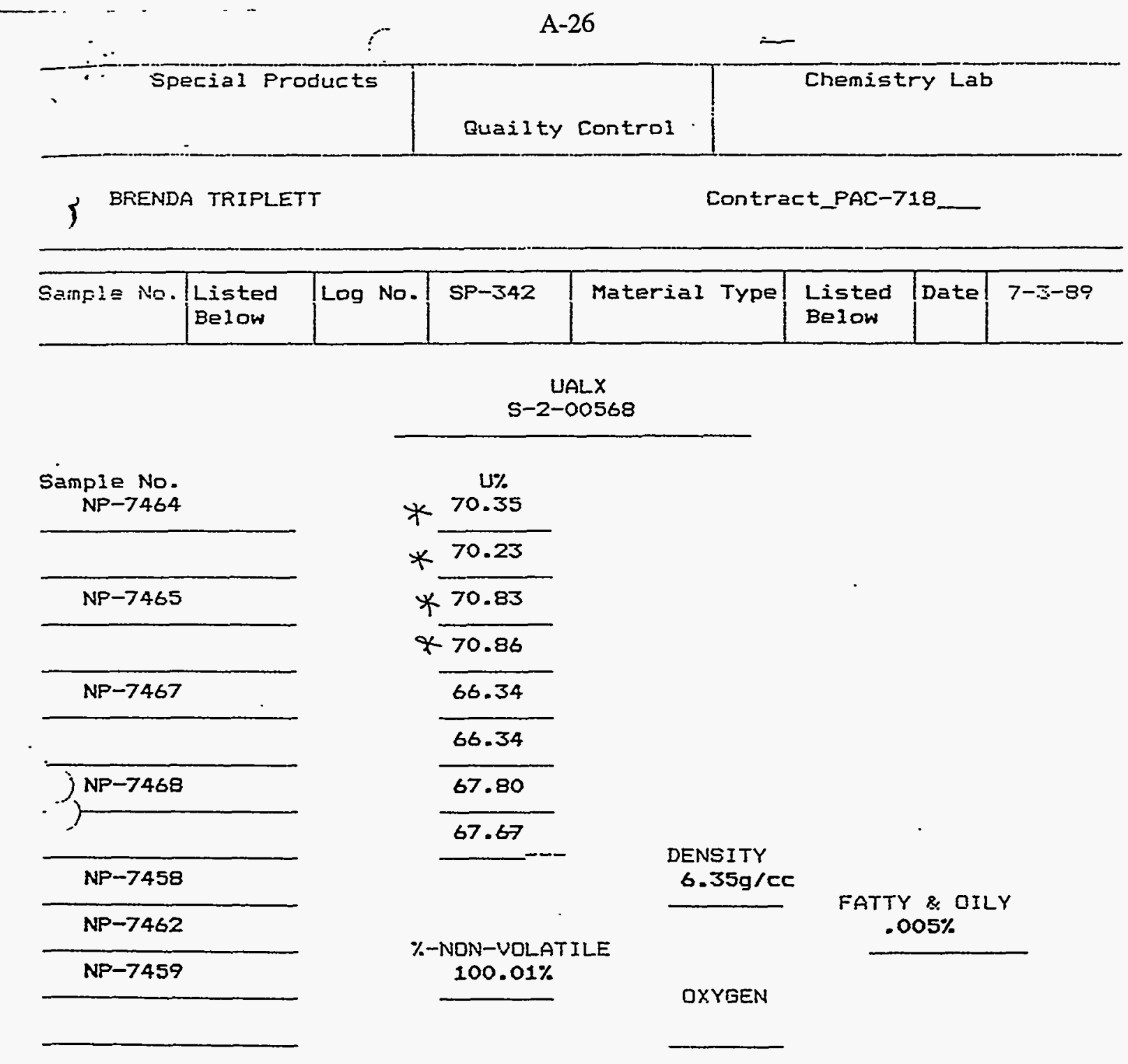

CC DANNY CARWILE

$$
\text { * arg. }-70.570
$$

Knowingly and wilfully falsifying or concealing a material fact on this form or making false, fictious or fraudulent statements or representations - rein could constitute a felony punishable under federal statues.<smiles>C[I-]C1CCCC1</smiles> 
1

FOR ANS
RECVD INED
$7-21-89$
HEU $U_{8}$
6 PAGES

Disribution

Q.C. Audit \& Release (1)

O.C. Foreman

Mig. Foremen

Prod. Control

John \& Lauie

Accountability

(1)
(1)
(1)

Contract/Job No.

$82 \mathrm{X}-99775 \mathrm{C}$

$$
6 \text { PAGES }
$$

$88 W$ certifies that the supplies listed hereon conform to all contract requirements, including all sp plicable statistical requirements, and that substantiating data ars on file.

\begin{tabular}{|c|c|c|c|c|c|}
\hline \multirow{2}{*}{$\begin{array}{l}\text { Roloss No. } \\
555-2806\end{array}$} & \multicolumn{3}{|c|}{ Component } & \multicolumn{2}{|c|}{ Spec. \& Rer. No. } \\
\hline & Name & Identification & & & \\
\hline $\begin{array}{l}\text { P.O. Numbor } \\
\text { N/A }\end{array}$ & $\begin{array}{l}\text { Enriched U308 } \\
\text { Urantum }\end{array}$ & Lot No. 512212 & & \multicolumn{2}{|c|}{$\begin{array}{l}\text { RRFE-UO-P, Revision } 0 \\
\text { dated } 7 / 19 / 82\end{array}$} \\
\hline $\begin{array}{l}\text { Sub-Contractor } \\
\text { GFM }\end{array}$ & $\begin{array}{r}\text { Drawing } \\
\text { N/A }\end{array}$ & $\begin{array}{l}\text { GR/PC }-N / A \\
\text { Rev._N/A }\end{array}$ & $\begin{array}{l}\text { List Oper. } \\
\text { Incoming } \\
\text { Inspection }\end{array}$ & $\begin{array}{l}\text { Reloase For } \\
\text { Production }\end{array}$ & $\left\{\begin{array}{l}\text { Qty. W Welght } \\
126,856.85\end{array}\right.$ \\
\hline
\end{tabular}

Remarks:

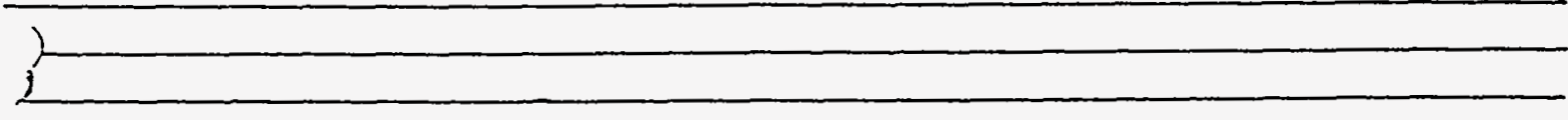

Waivers: NONE

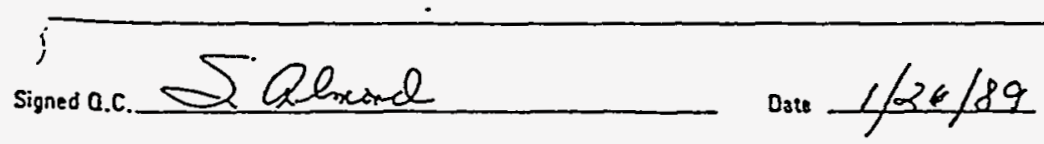




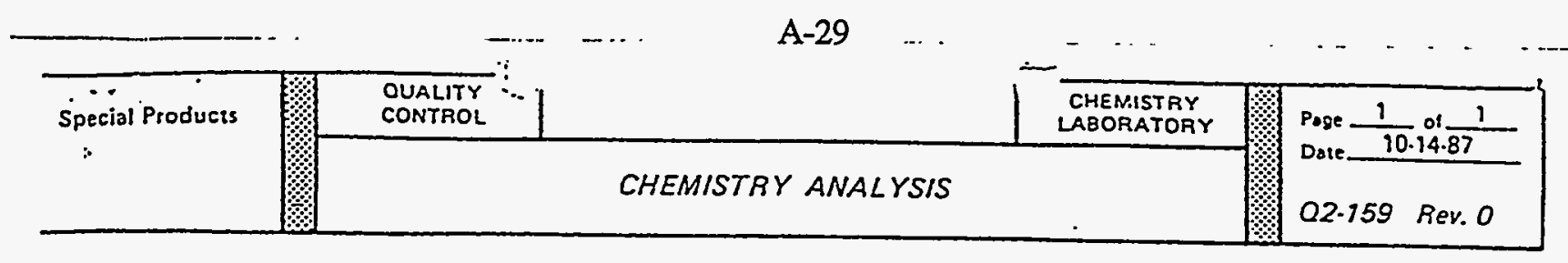

$\operatorname{Tr} \rho$ carvile $f_{31}$

\begin{tabular}{|l|l|l|l|l|}
\hline imole No. Listed Below & Los No. C-63370 & Material Type Listed Below & Date & $5-31-88$ \\
\hline
\end{tabular}

NPN-5 5.5

$$
\begin{aligned}
& \text { FZF- FCW }-48 \\
& \text { Lot } \# 512212 \quad \text { PAC }-504
\end{aligned}
$$

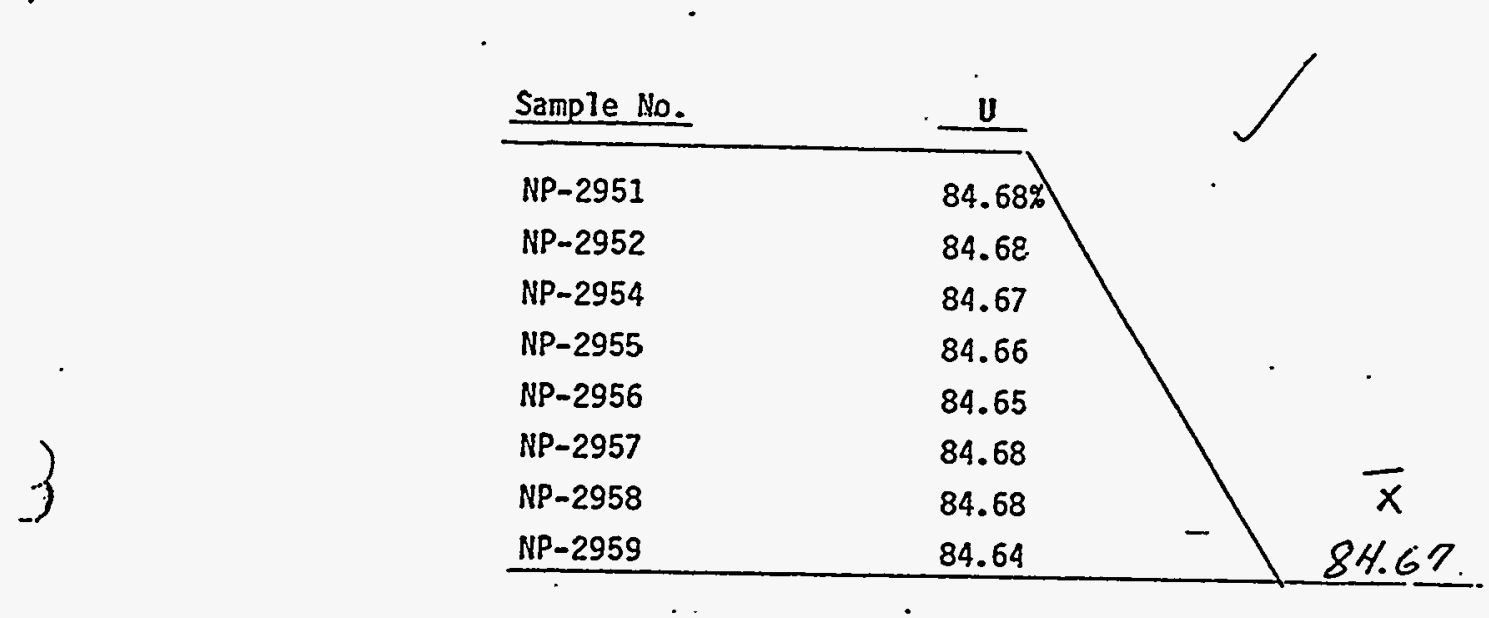




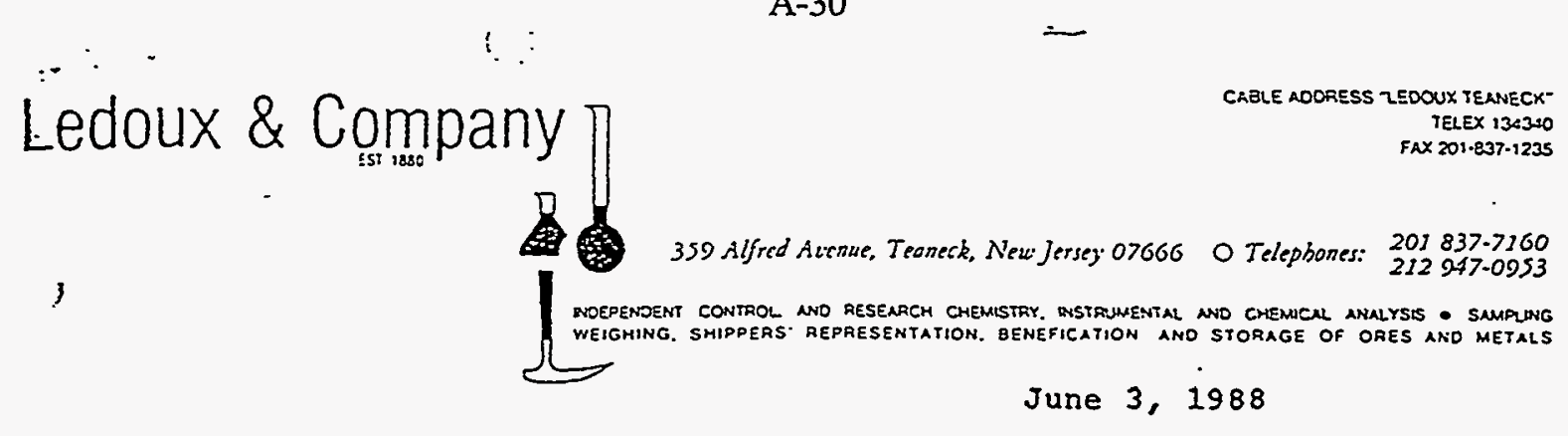

Ledoux \& Company Analysis : 1085002

Material identified by client as: U308 Powder LOT \# 5\$2/₹ Purchase Order : DMP-00381

Samples Marked : NP-2960

FZF-FCW- 48

PAE $5 C 4$

submitted to us for analysis by : Babcock \& Hilcox

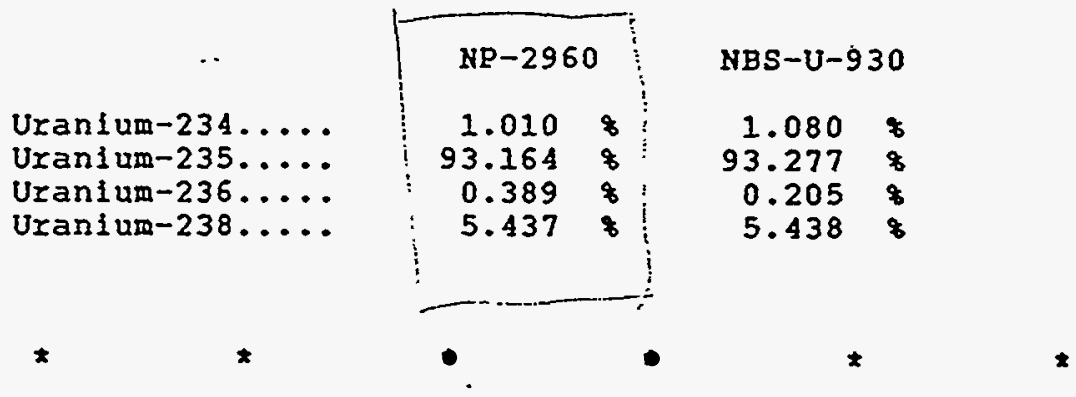

Invoice and 2 to: Babcock \& Wilcox Company

LEDOUX \& COMPANY

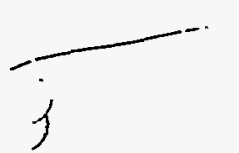

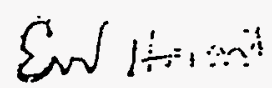

NO WARRANTY IS EXTENDED IN RESPECT TO SERVICES PROVIDED BY LEDOUX \& COMPANY (PLEASE SEE REVERSE SIDE) 


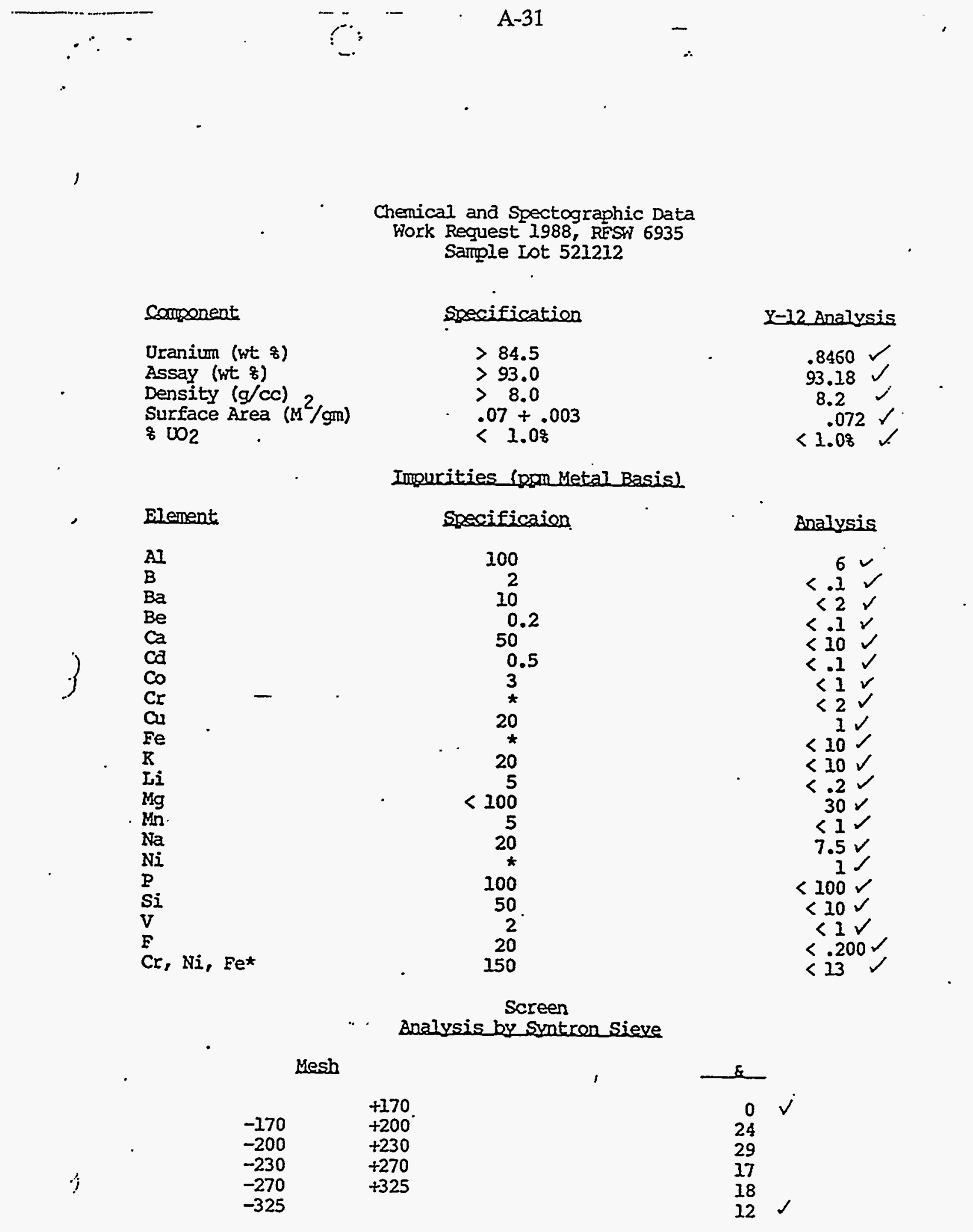




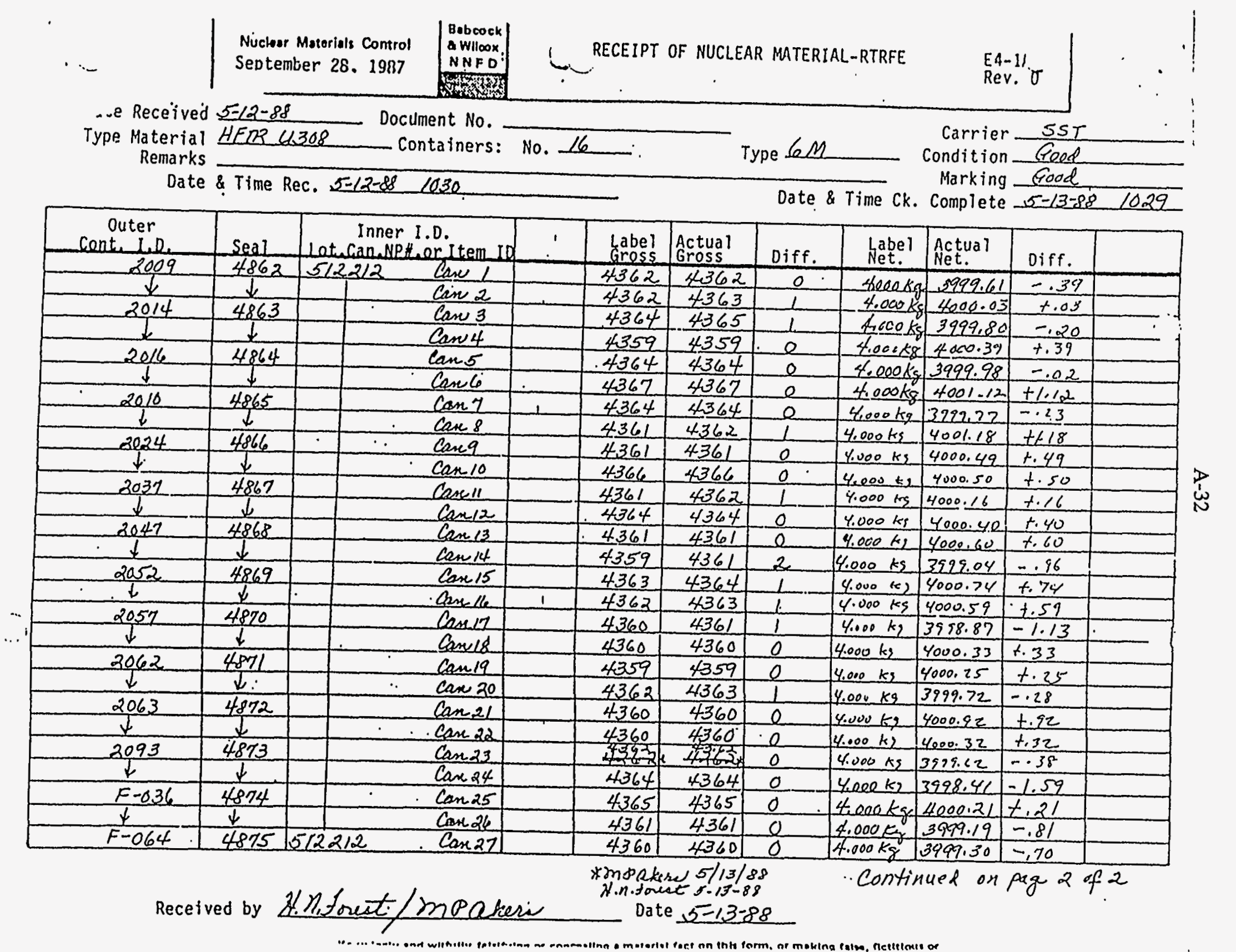




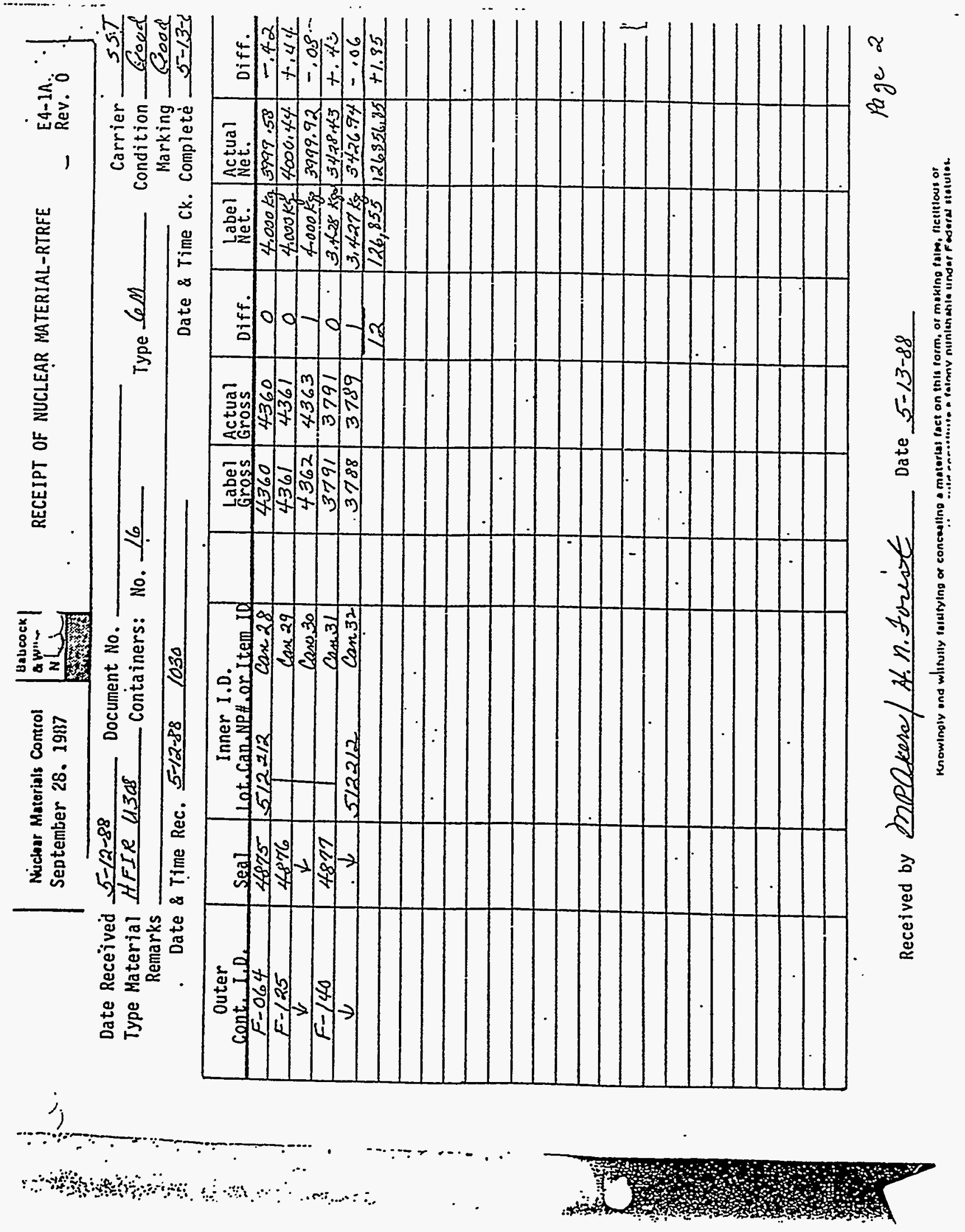



Appendix B. SUPPLEMENTARY OPTICAL AND SCANNING ELECTRON MICROGRAPHS OF HANS-1 AND HANS-2 FUEL SAMPLE 


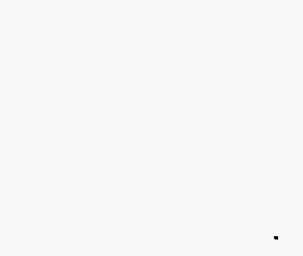

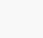




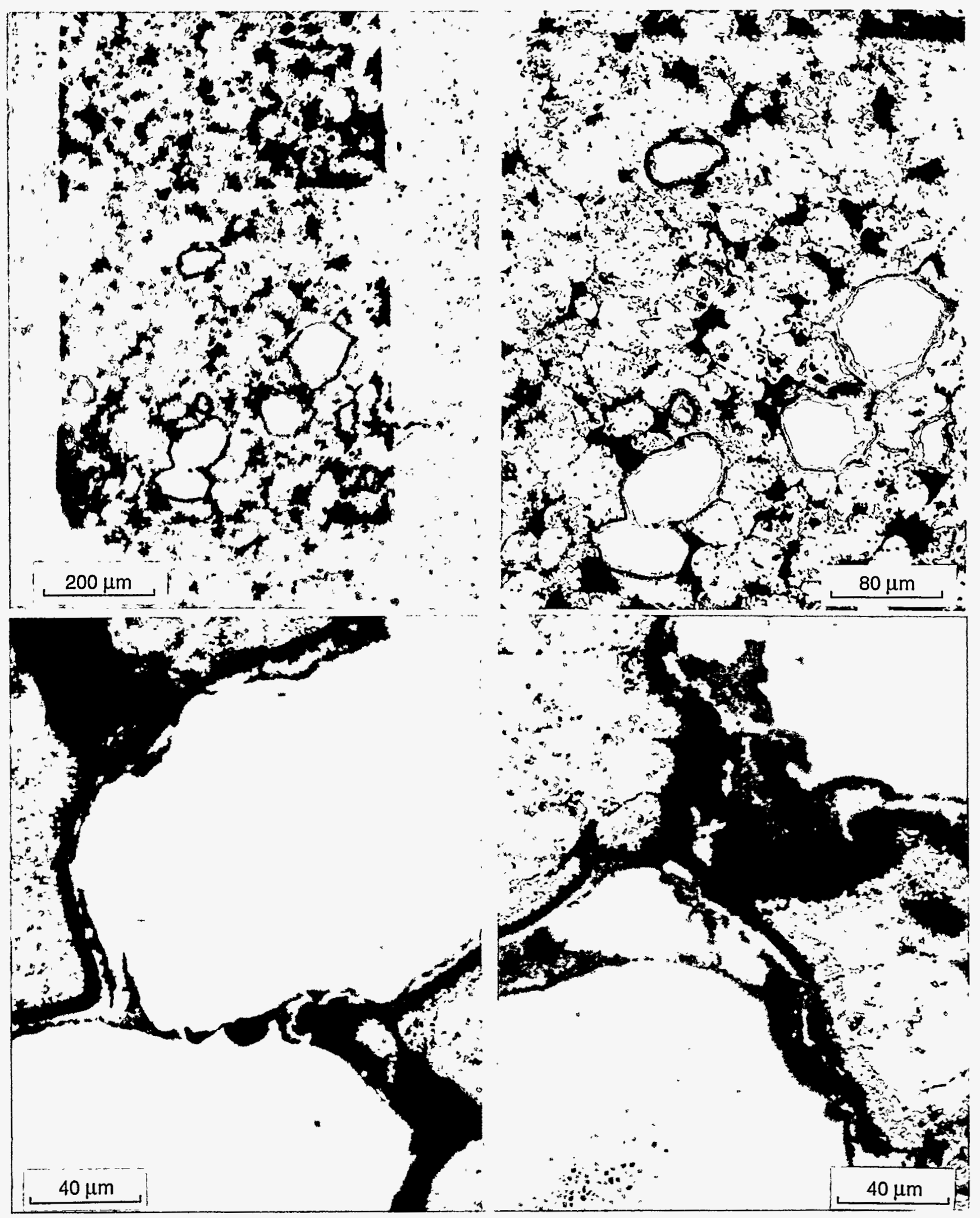

HANS-1, Sample \#9, $\mathrm{U}_{3} \mathrm{Si}_{2}, 425^{\circ} \mathrm{C}$, Optical 
B-4

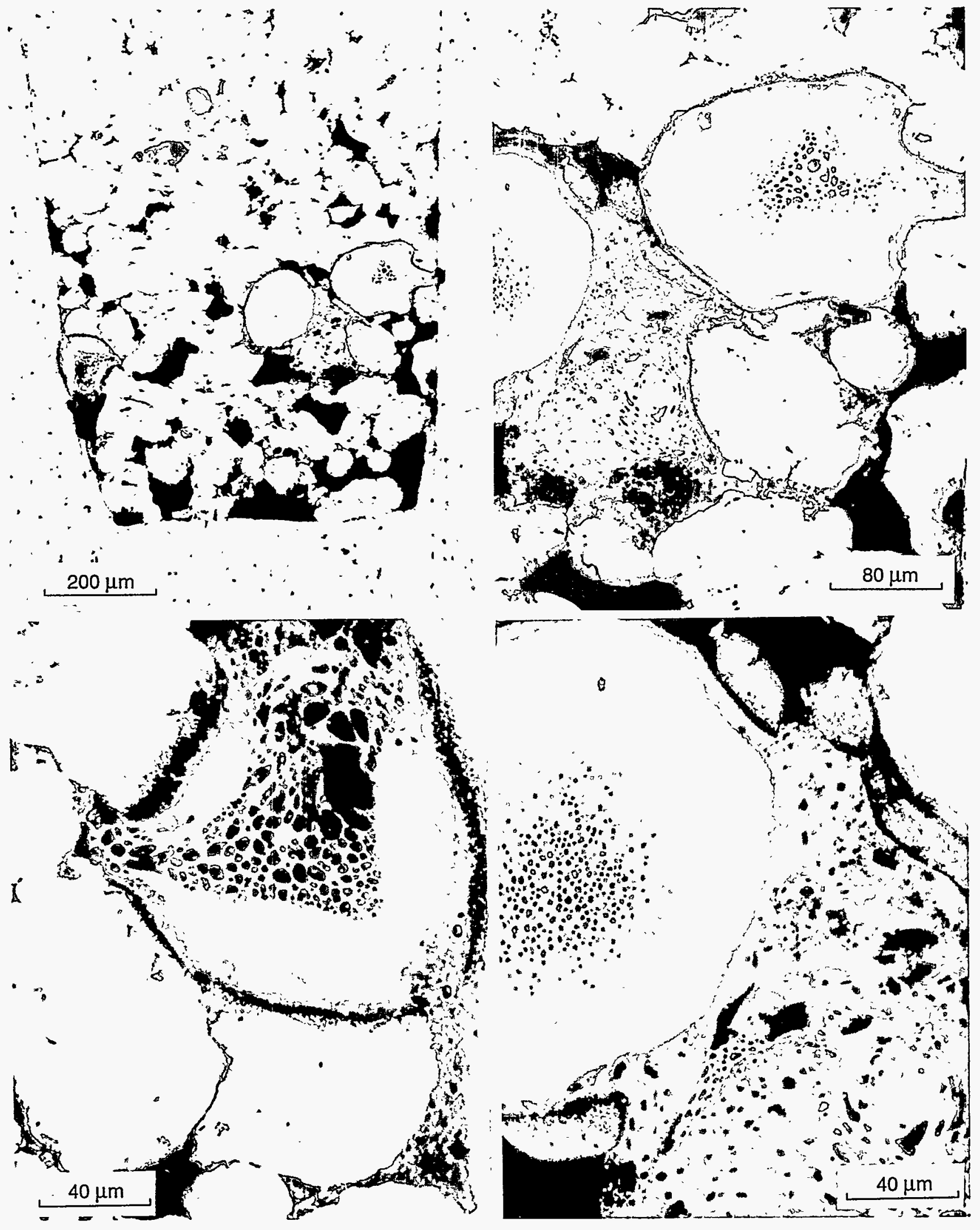

HANS-1, Sample \#15, $\mathrm{U}_{3} \mathrm{Si}_{2}, 425^{\circ} \mathrm{C}$, Optical 


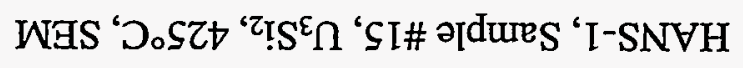

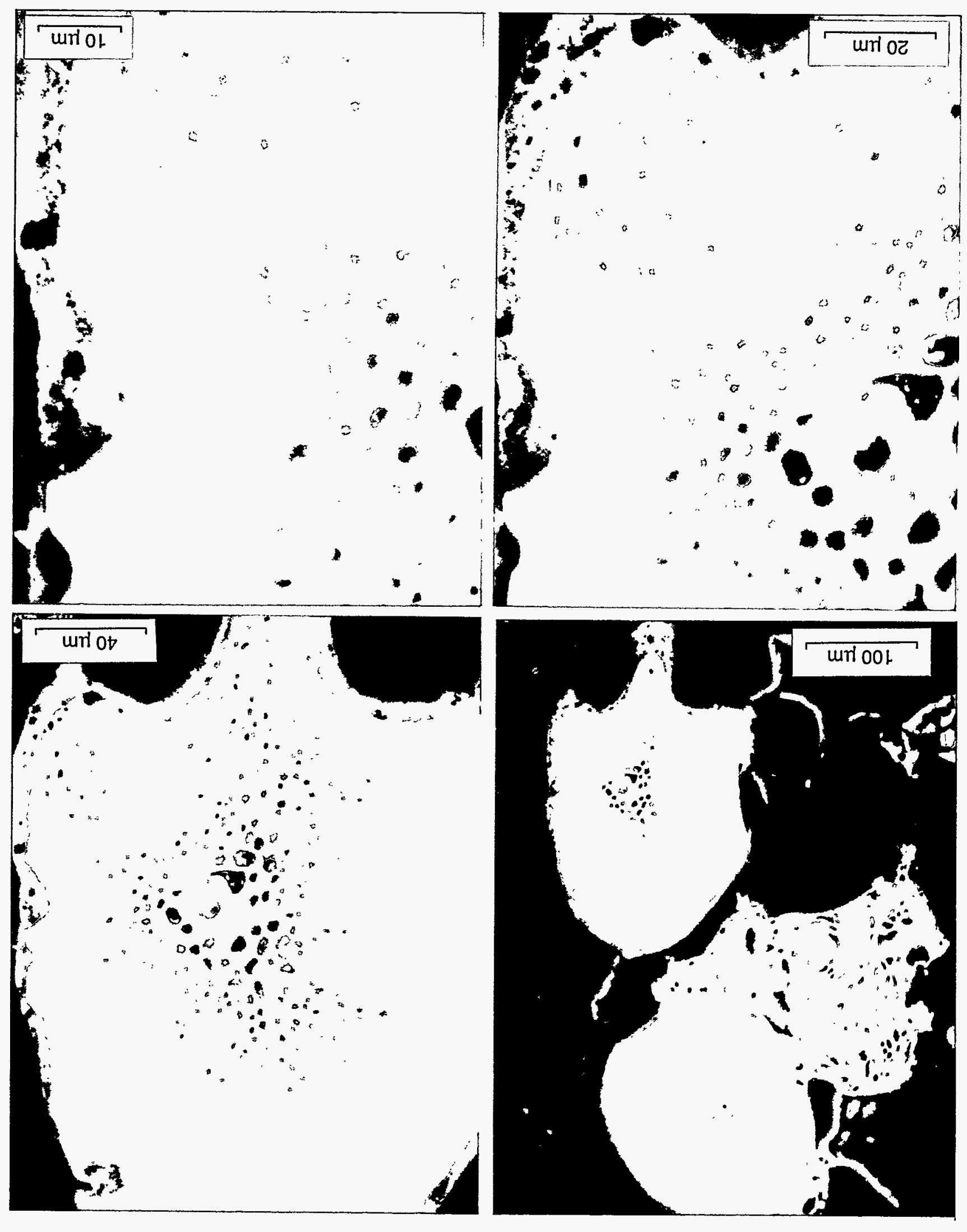


B-6

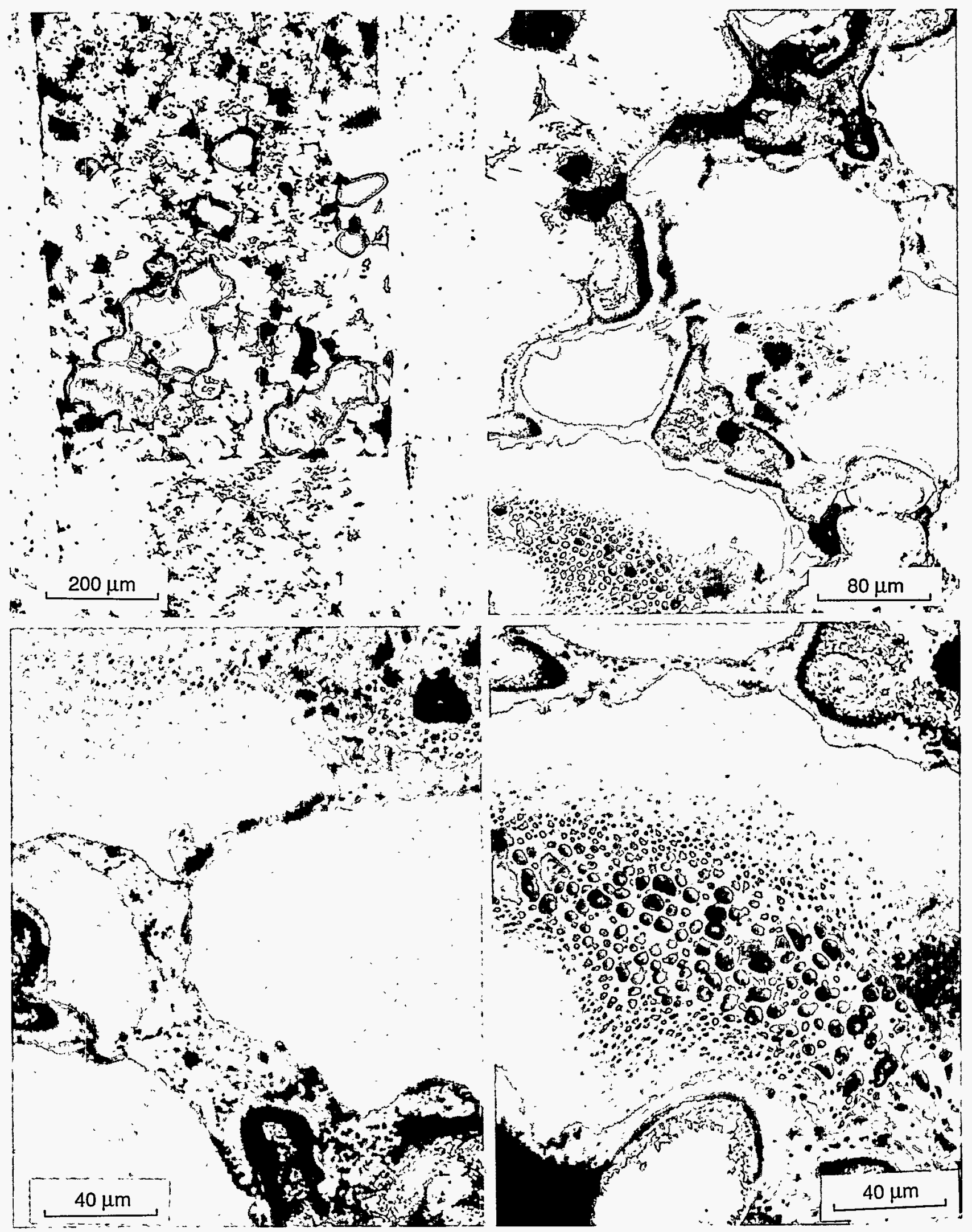

HANS-1, Sample \#10, $\mathrm{U}_{3} \mathrm{Si}_{2}, 425^{\circ} \mathrm{C}$, Optical 
B-7
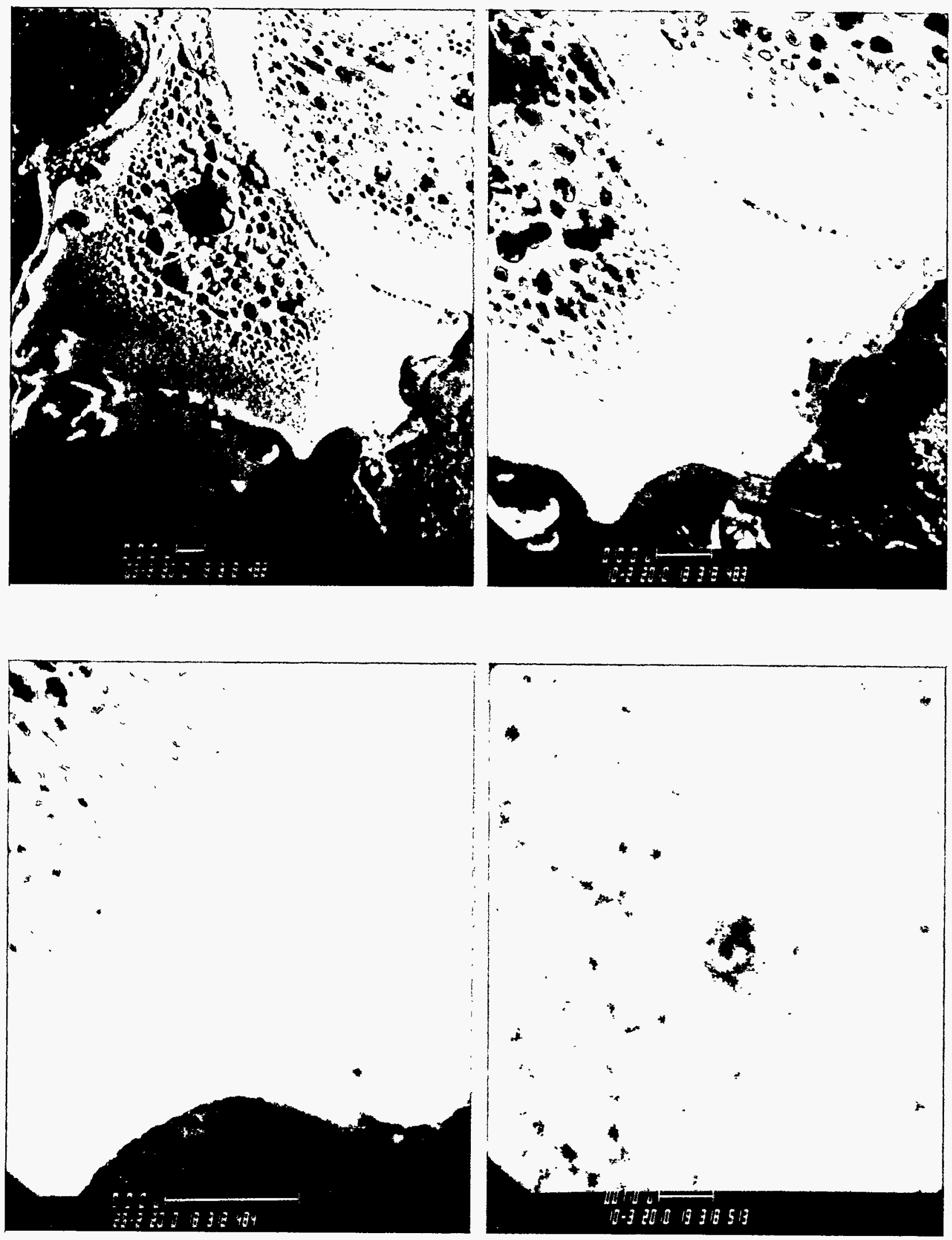

HANS-1, Sample \#10, $\mathrm{U}_{3} \mathrm{Si}_{2}, 425^{\circ} \mathrm{C}$, SEM 


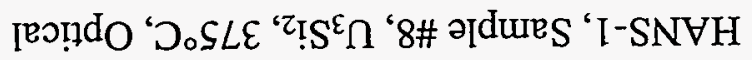

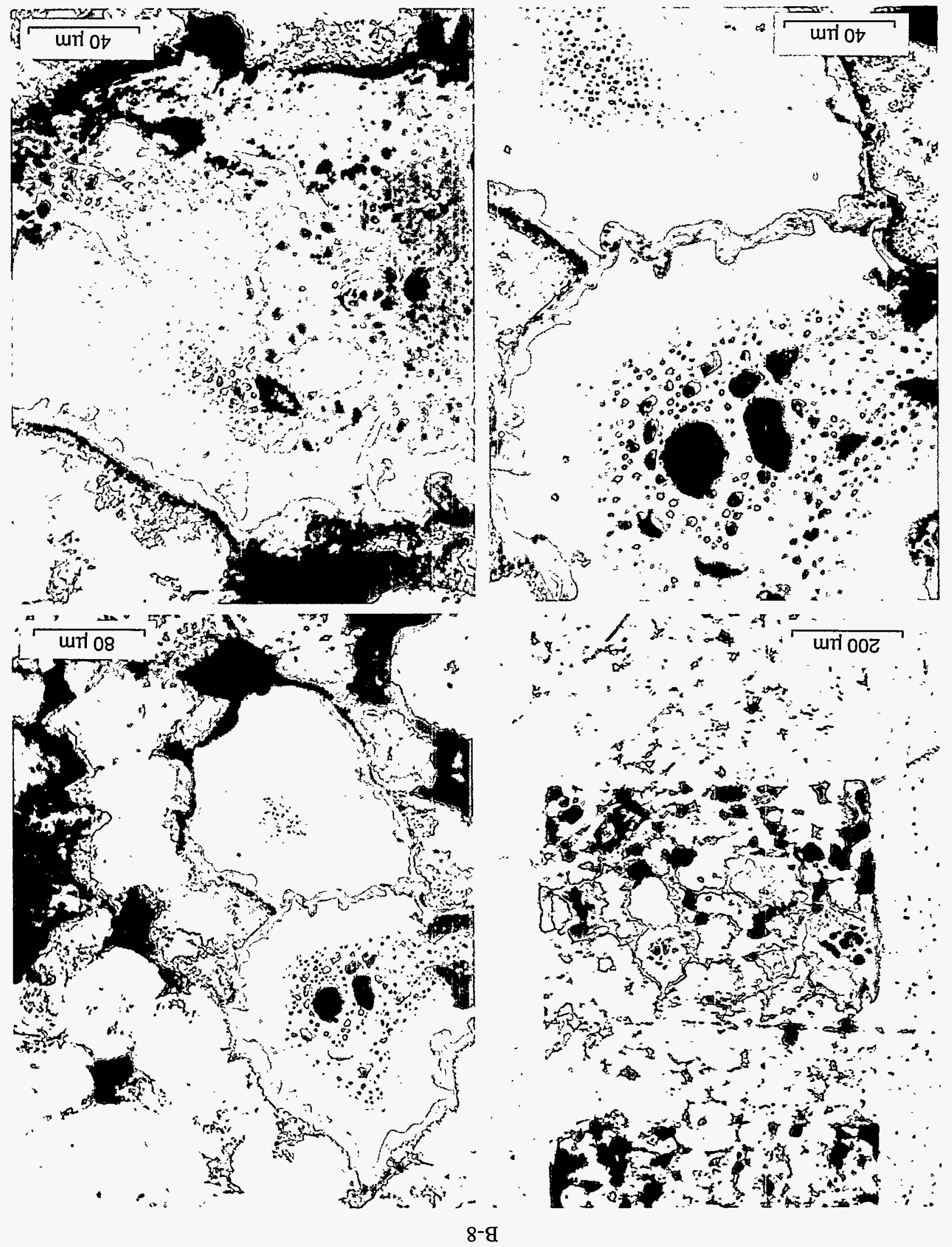


B-9

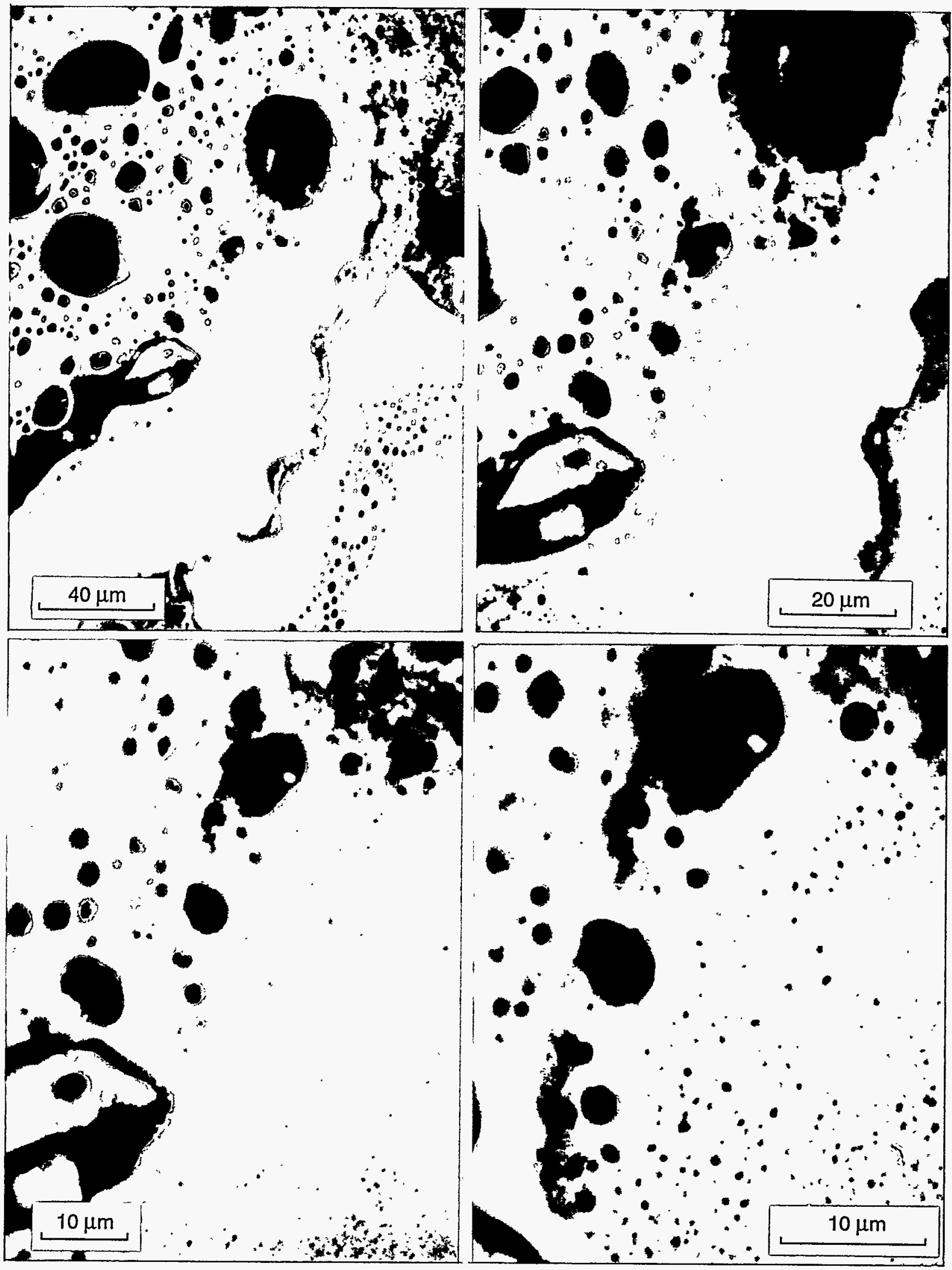

HANS-1, Sample \#8, $\mathrm{U}_{3} \mathrm{Si}_{2}, 375^{\circ} \mathrm{C}$, SEM 


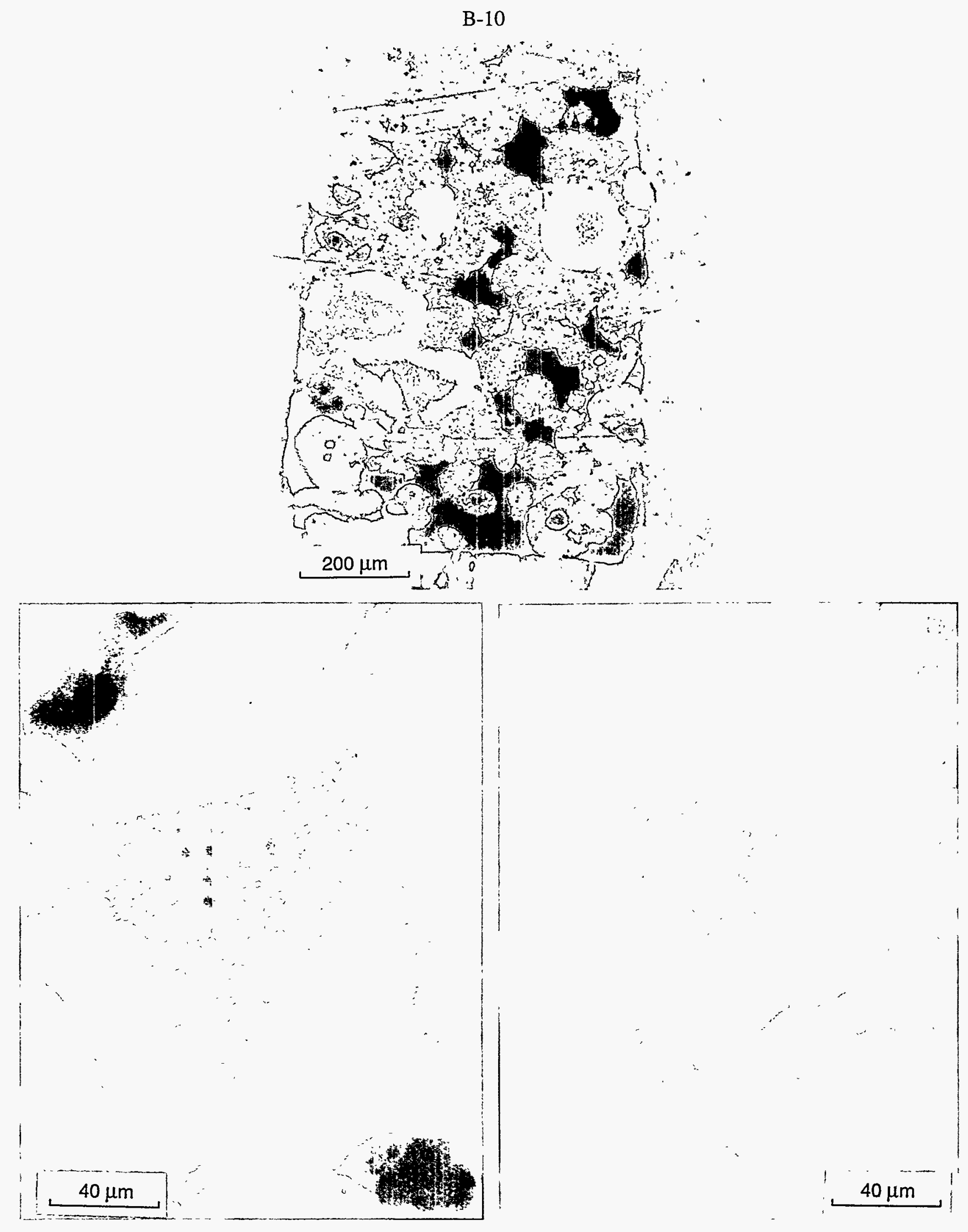

HANS-1, Sample \#16, $\mathrm{U}_{3} \mathrm{Si}_{2}, 375^{\circ} \mathrm{C}$, Optical 
B-11
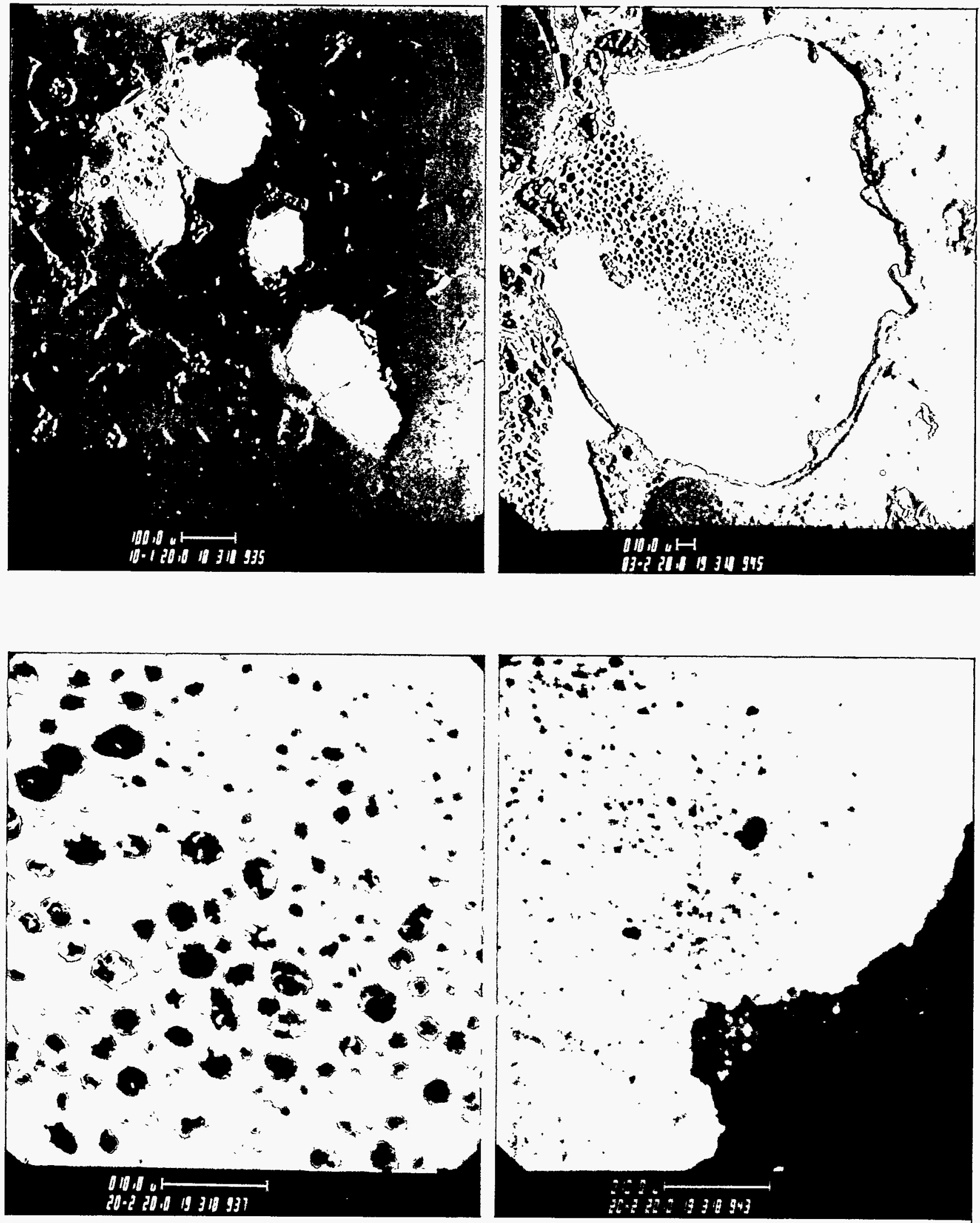

HANS-1, Sample \#16, $\mathrm{U}_{3} \mathrm{Si}_{2}, 375^{\circ} \mathrm{C}$, SEM 
B-12

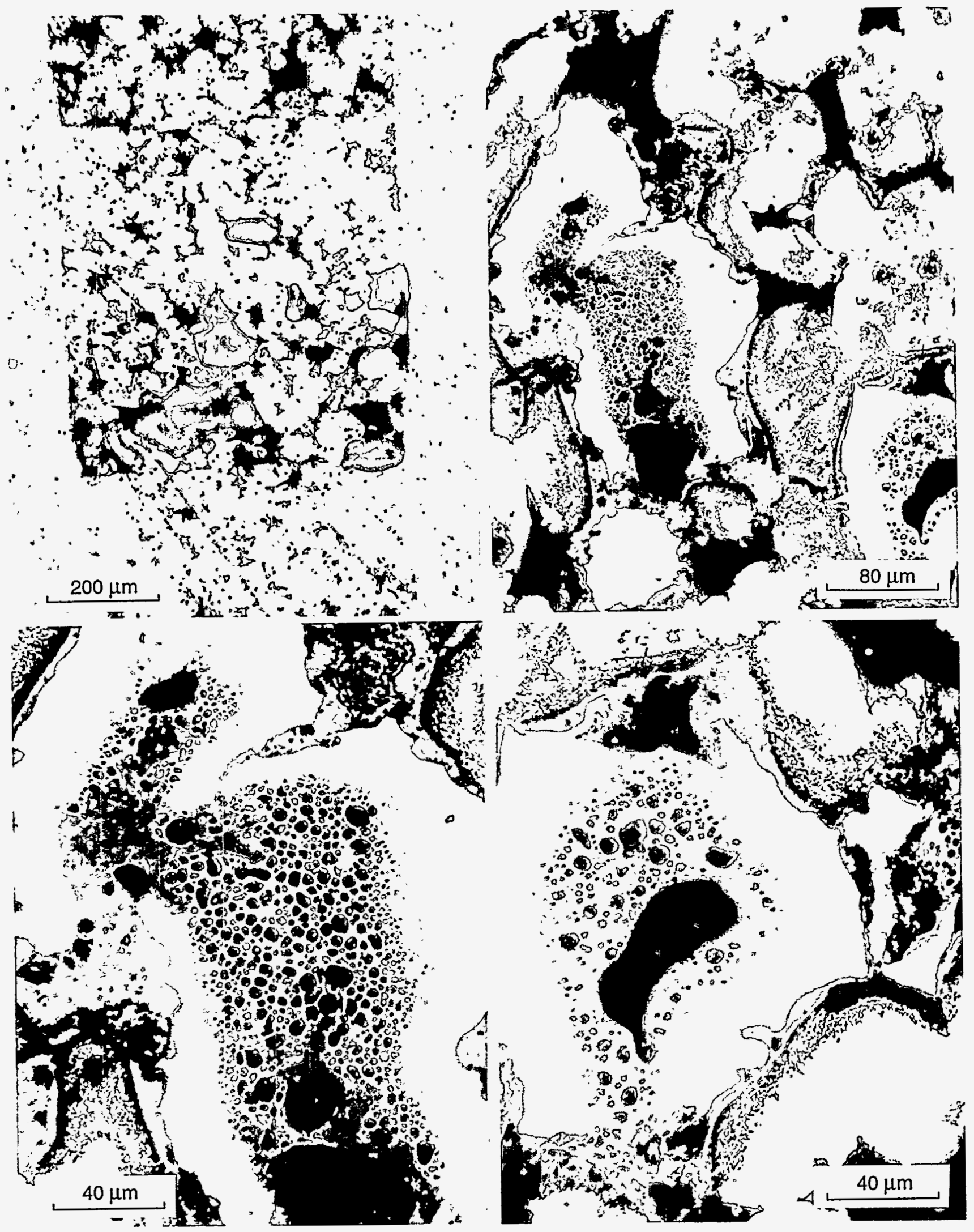

HANS-1, Sample \#17, $\mathrm{U}_{3} \mathrm{Si}_{2}, 325^{\circ} \mathrm{C}$, Optical 
B-13
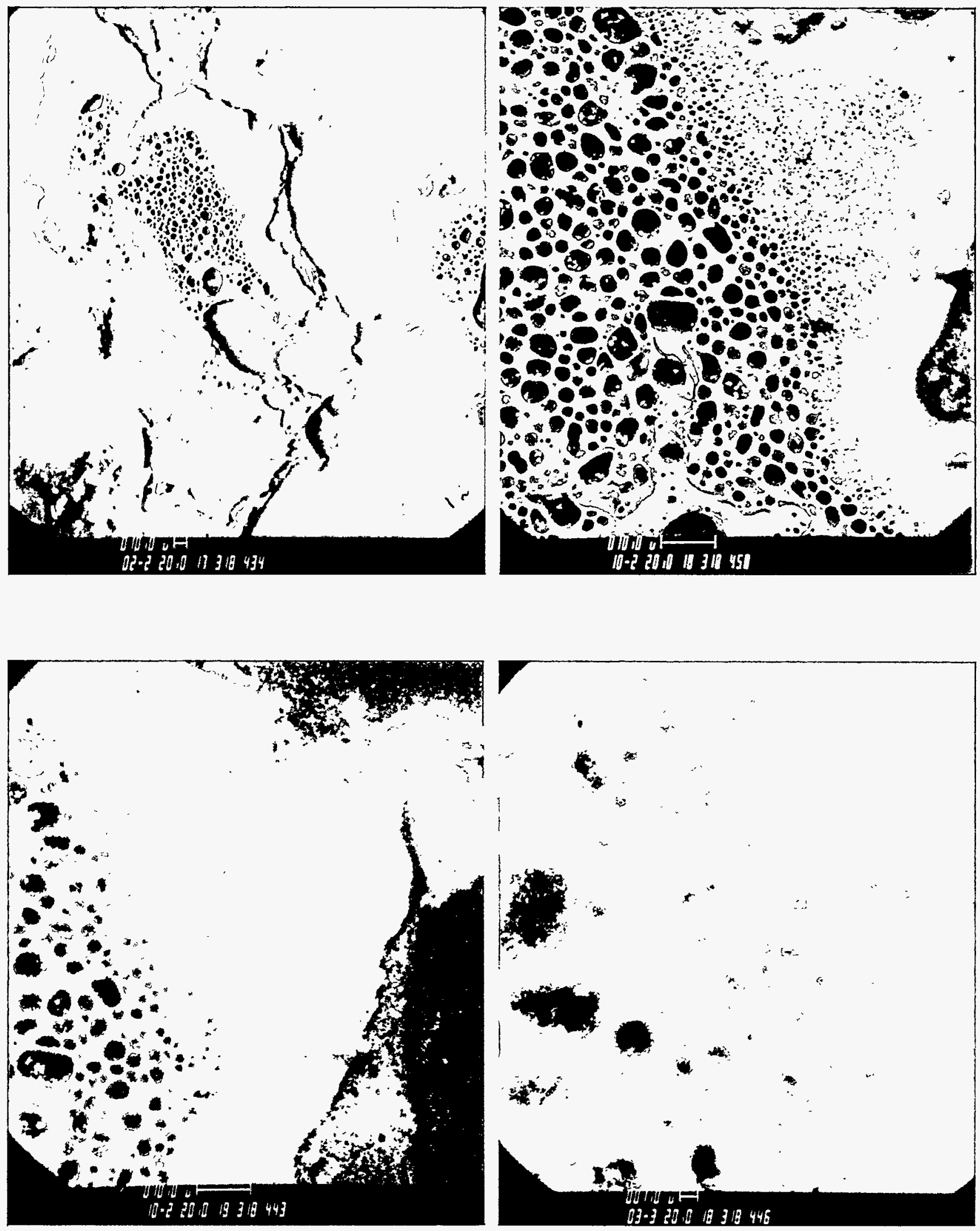

HANS-1, Sample \#17, $\mathrm{U}_{3} \mathrm{Si}_{2}, 325^{\circ} \mathrm{C}$, SEM 
B-14

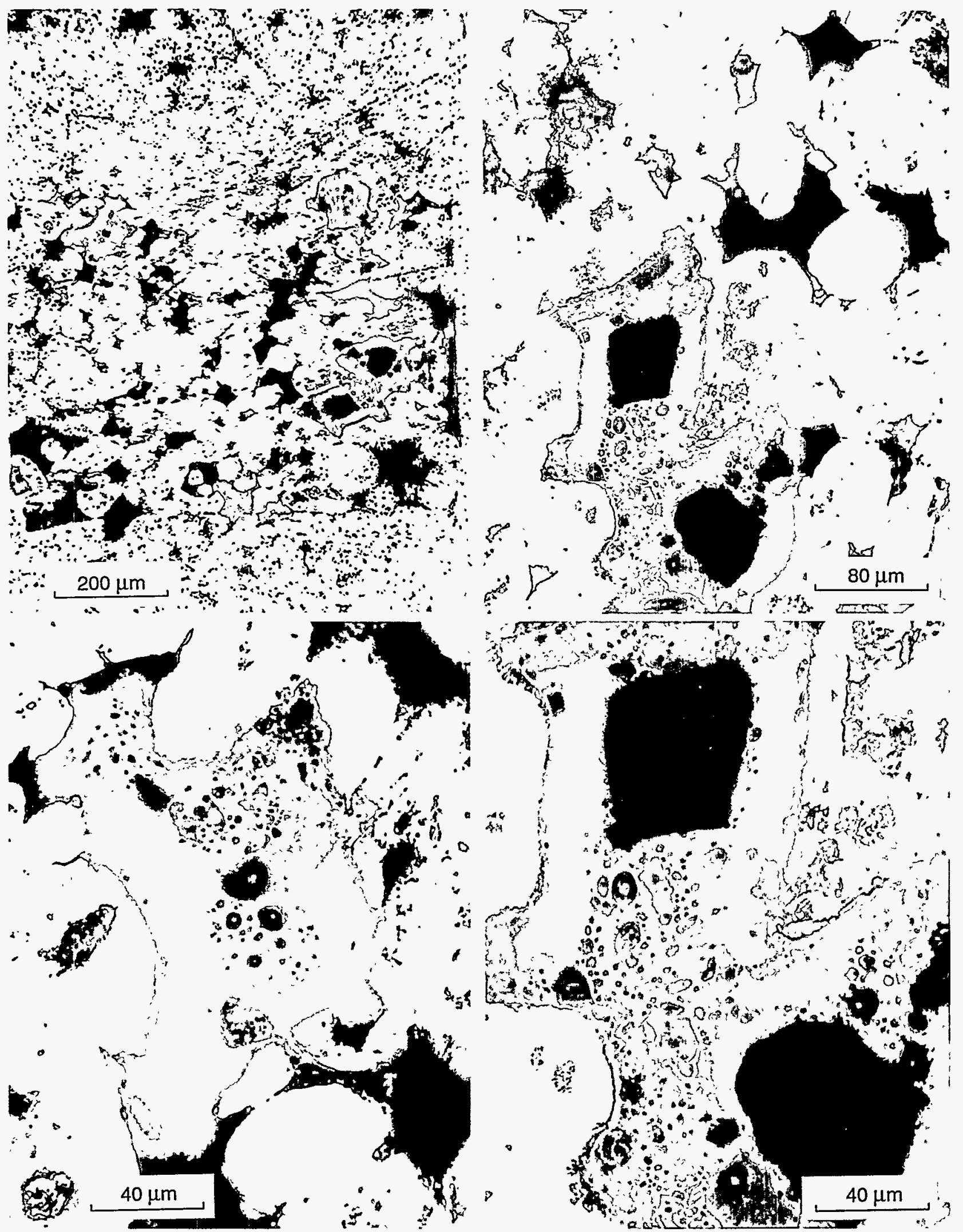

HANS-1, Sample \#7, $\mathrm{U}_{3} \mathrm{Si}_{2}, 325^{\circ} \mathrm{C}$, Optical 


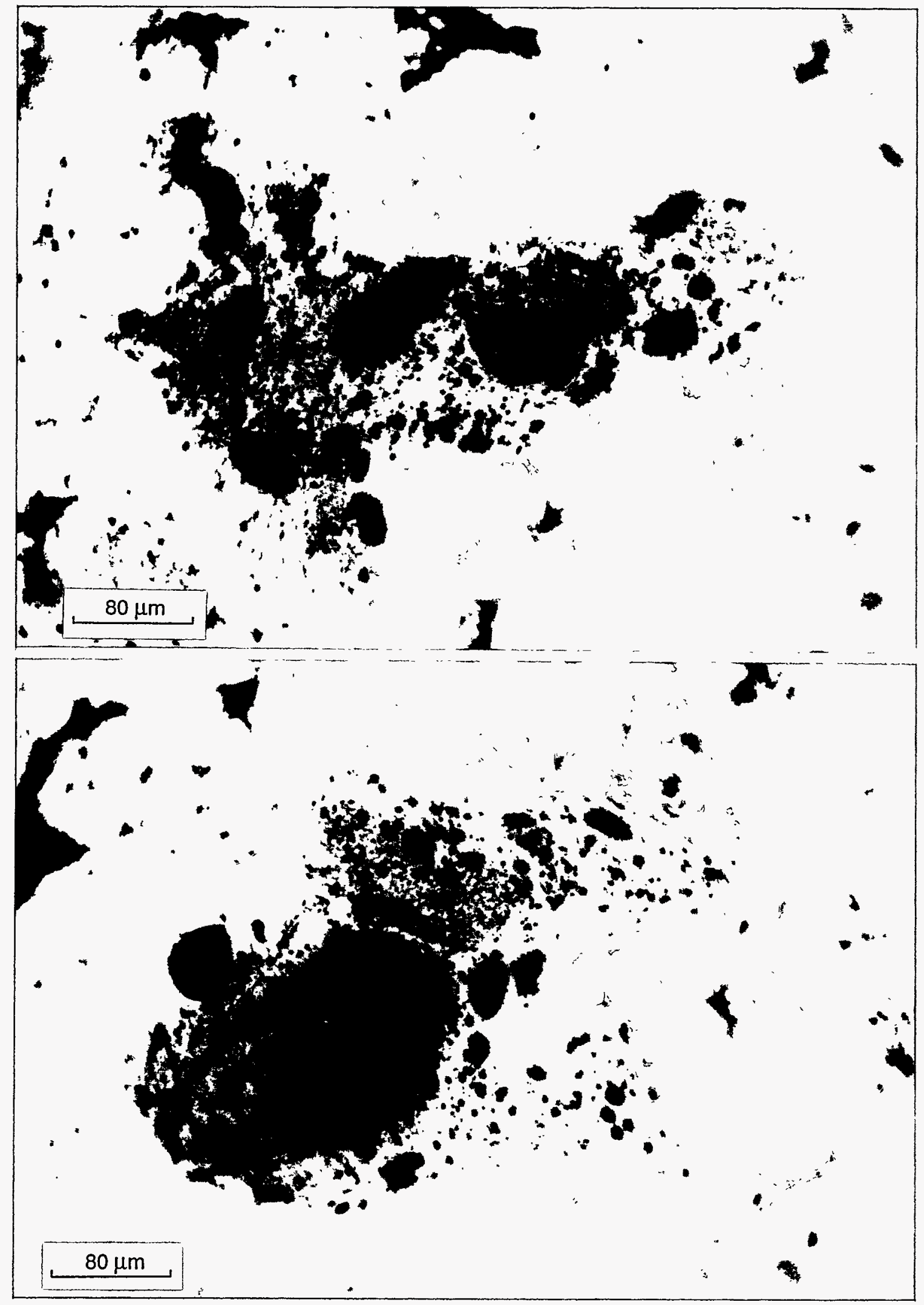

HANS-1, Sample \#4, $\mathrm{U}_{3} \mathrm{Si}_{2}, 250^{\circ} \mathrm{C}$, Optical 
B-16
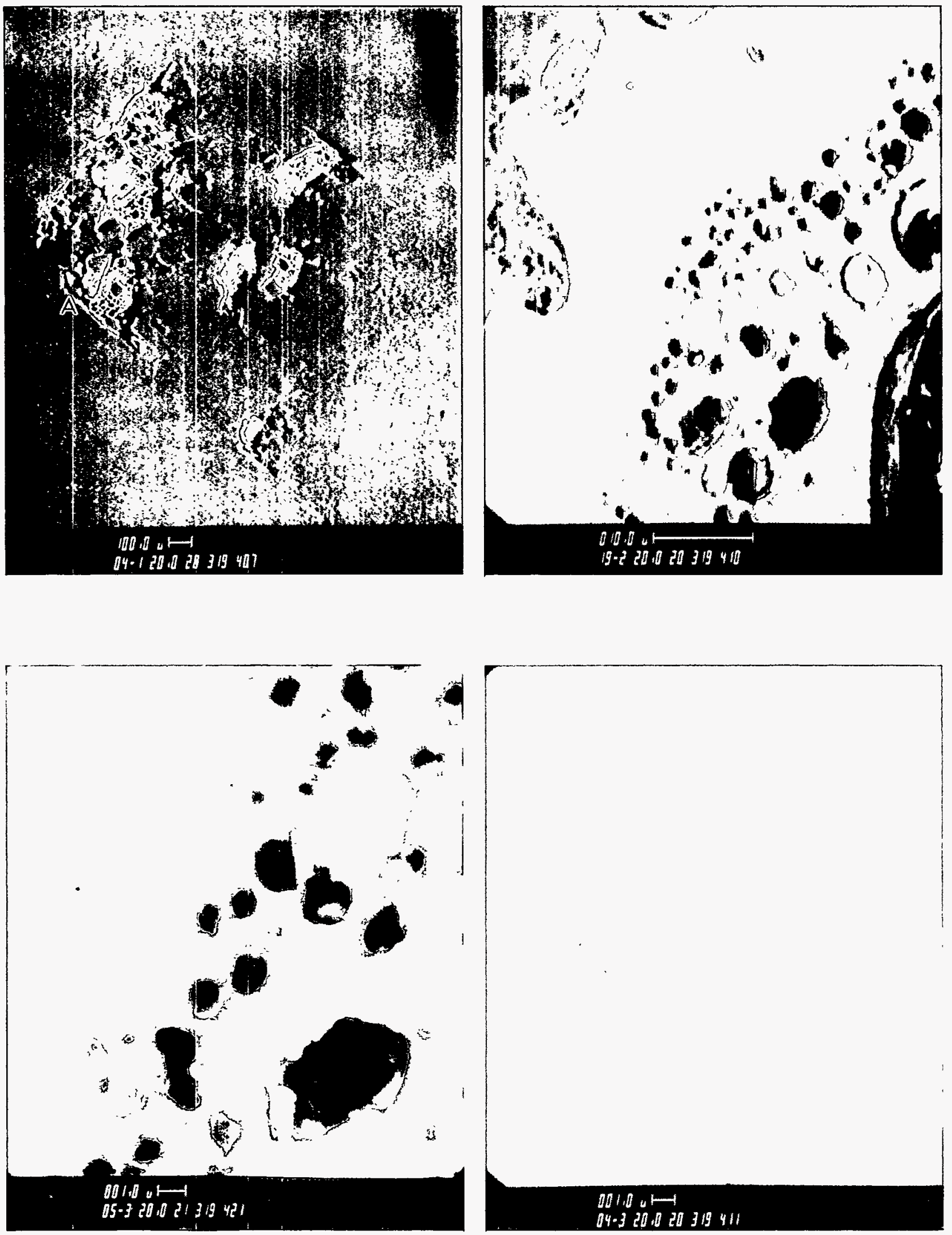

HANS-1, Sample \#18, $\mathrm{U}_{3} \mathrm{Si}_{2}, 250^{\circ} \mathrm{C}$, SEM 
B-17

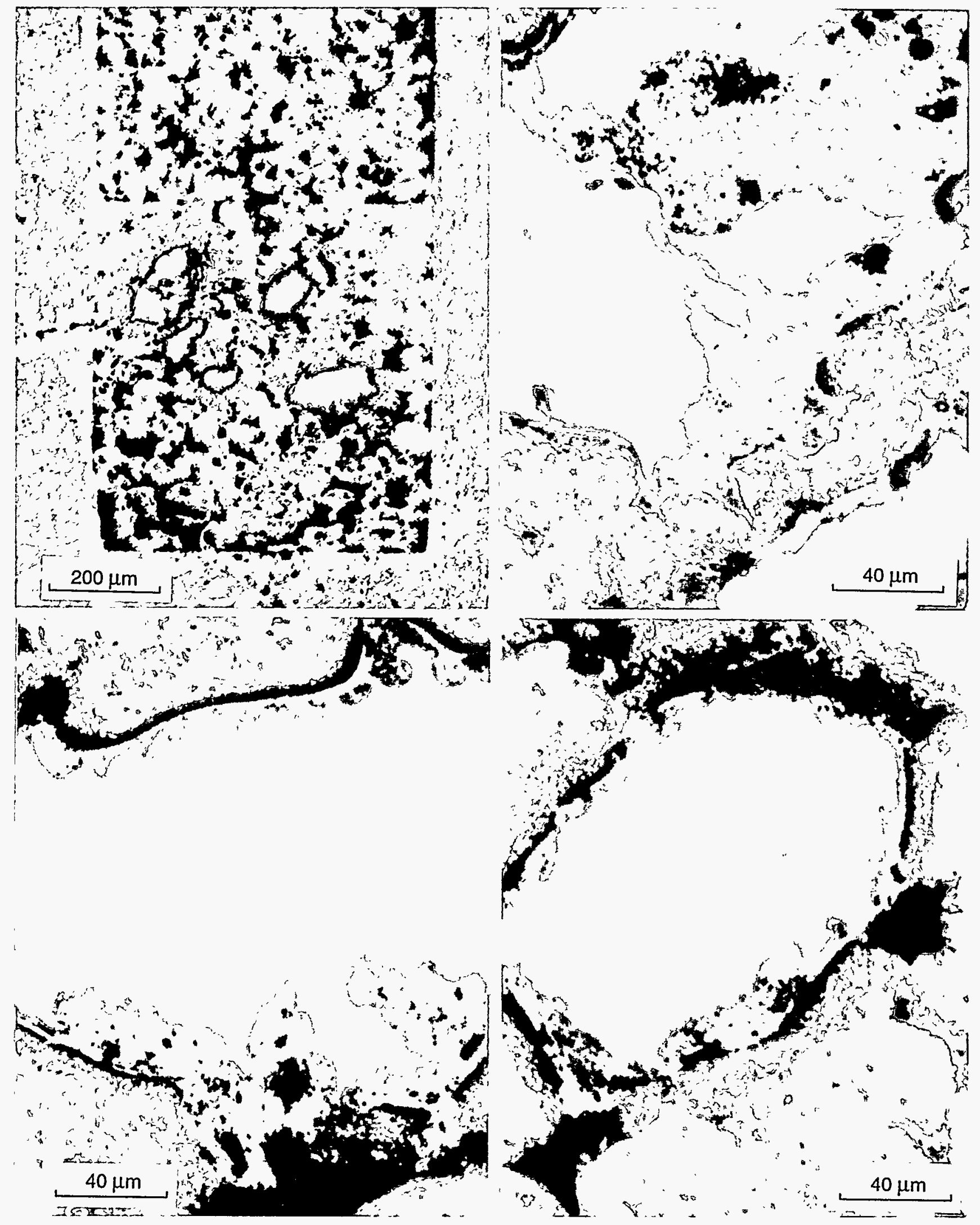

HANS-1, Sample \#14, $\mathrm{U}_{3} \mathrm{Si}, 375^{\circ} \mathrm{C}$, Optical 

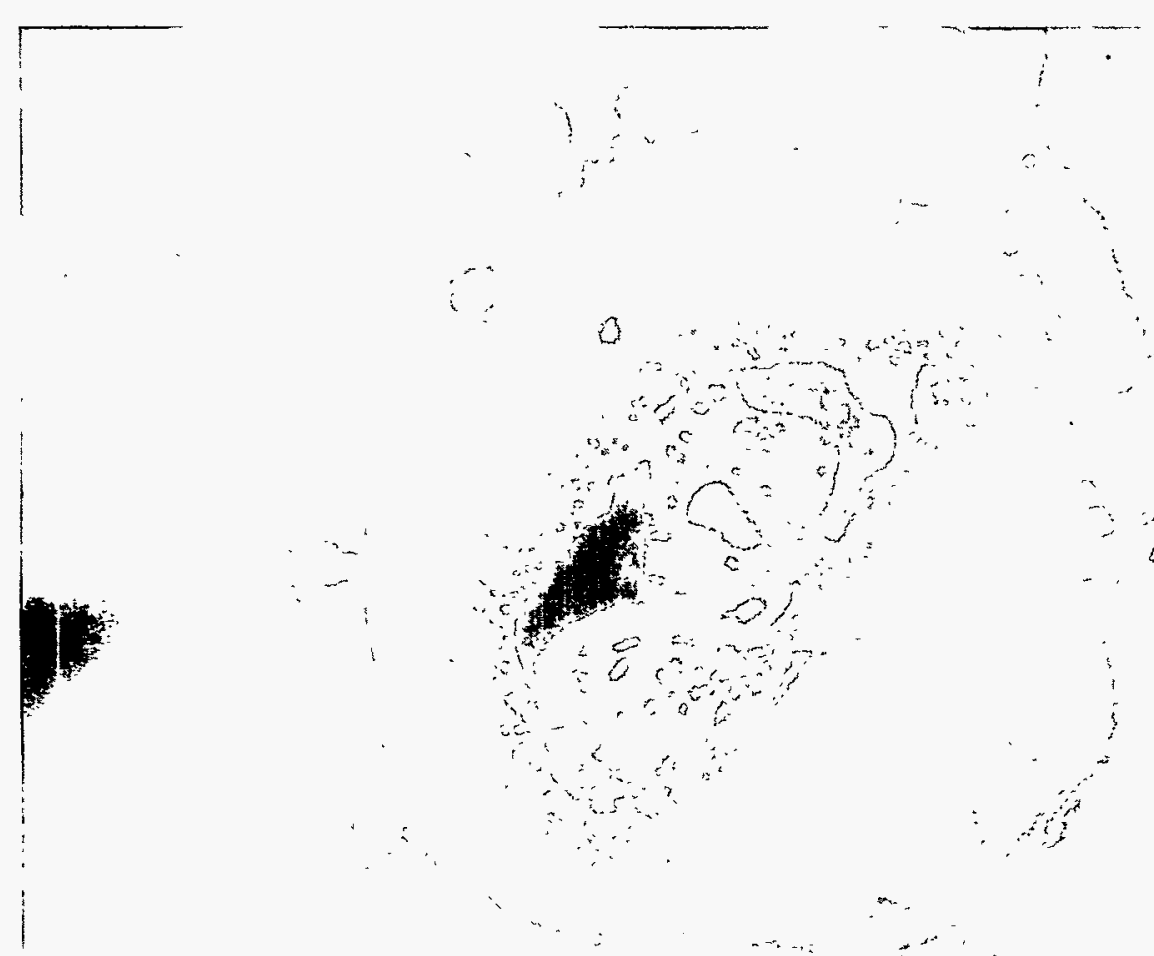


\section{B-19}
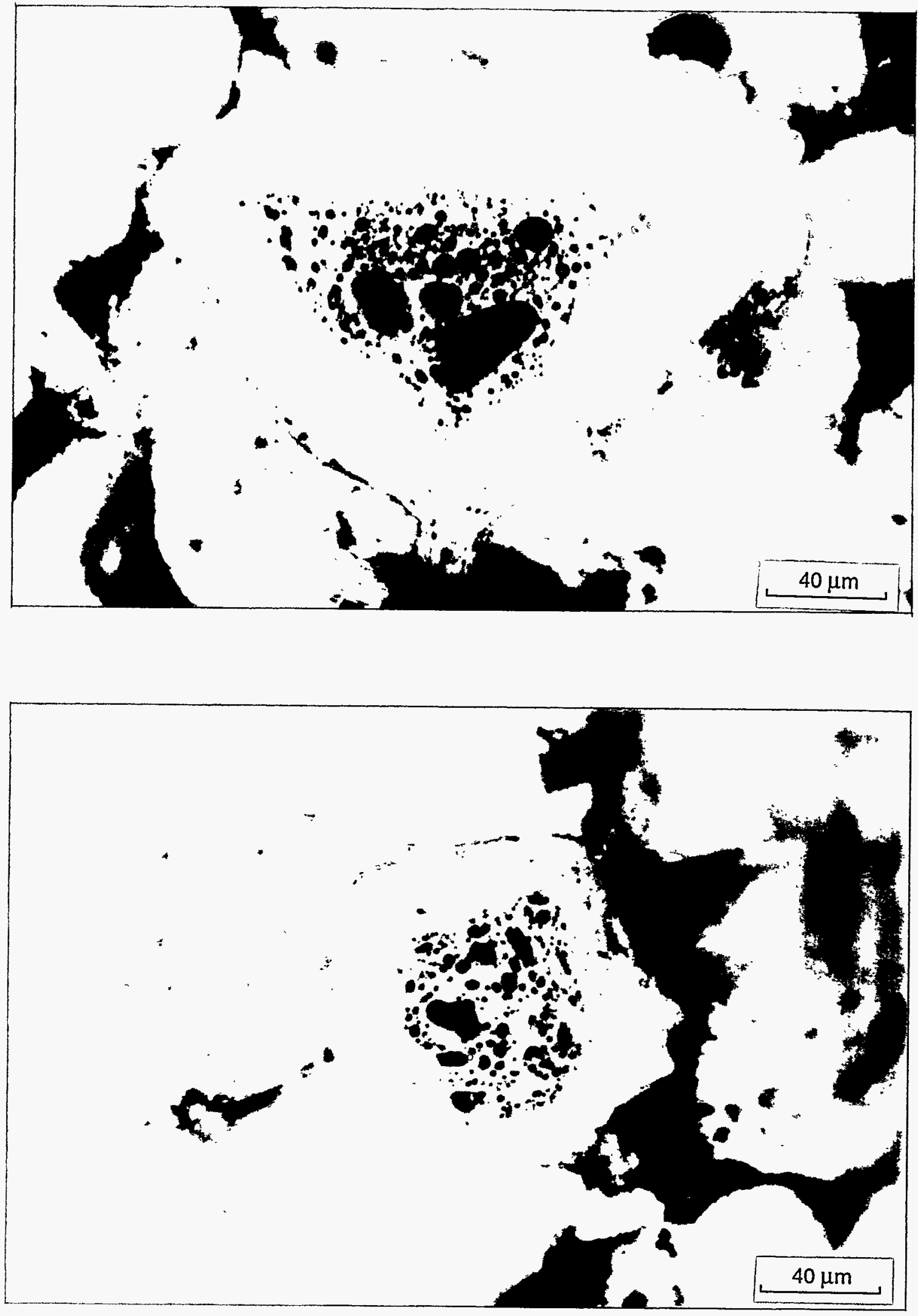

HANS-2, Sample \#14, $\mathrm{U}_{3} \mathrm{Si}_{2}, 325^{\circ} \mathrm{C}$, Optical 
B-20
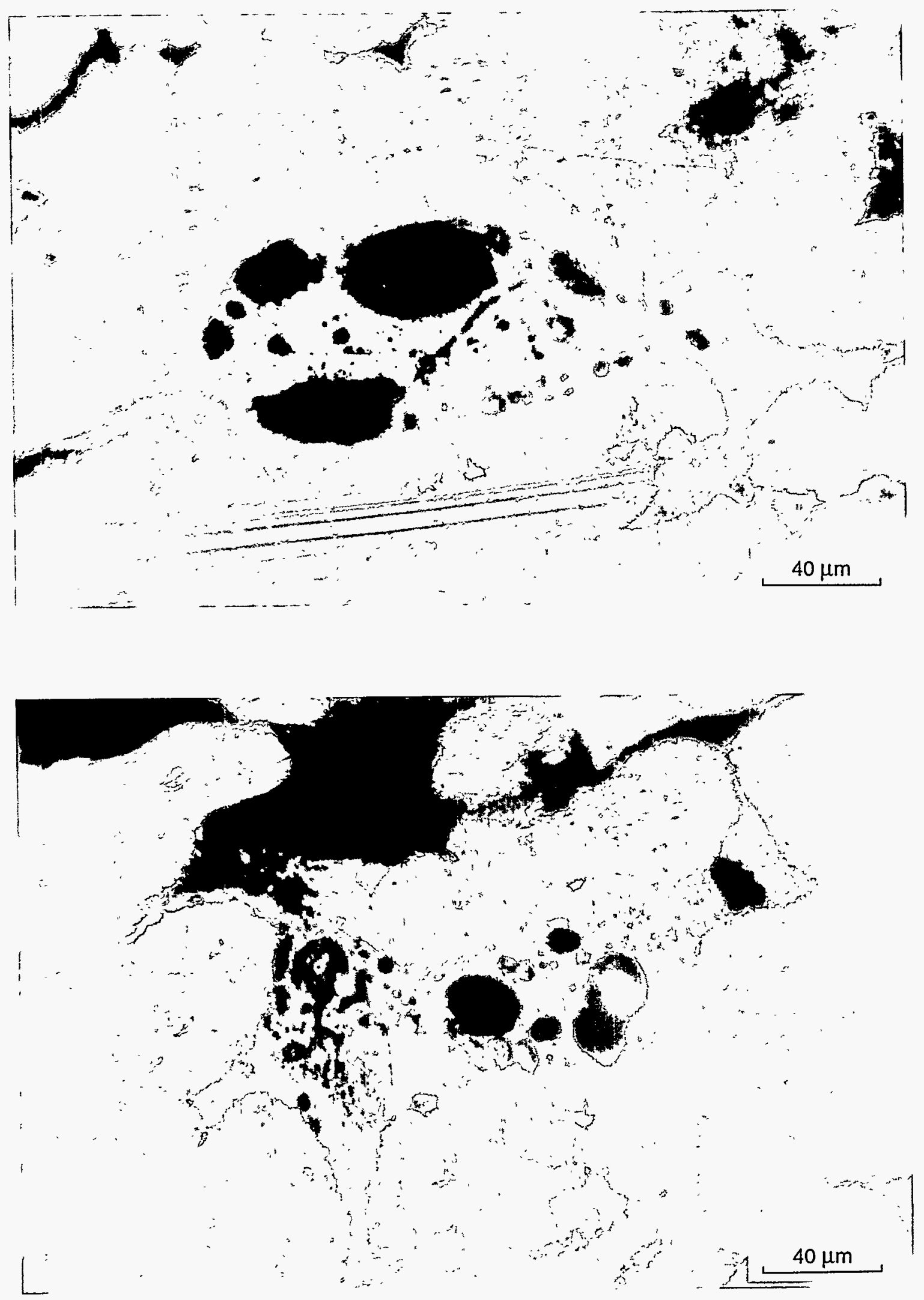

HANS-2, Sample \#16, $\mathrm{U}_{3} \mathrm{Si}_{2}, 250^{\circ} \mathrm{C}$, Optical 

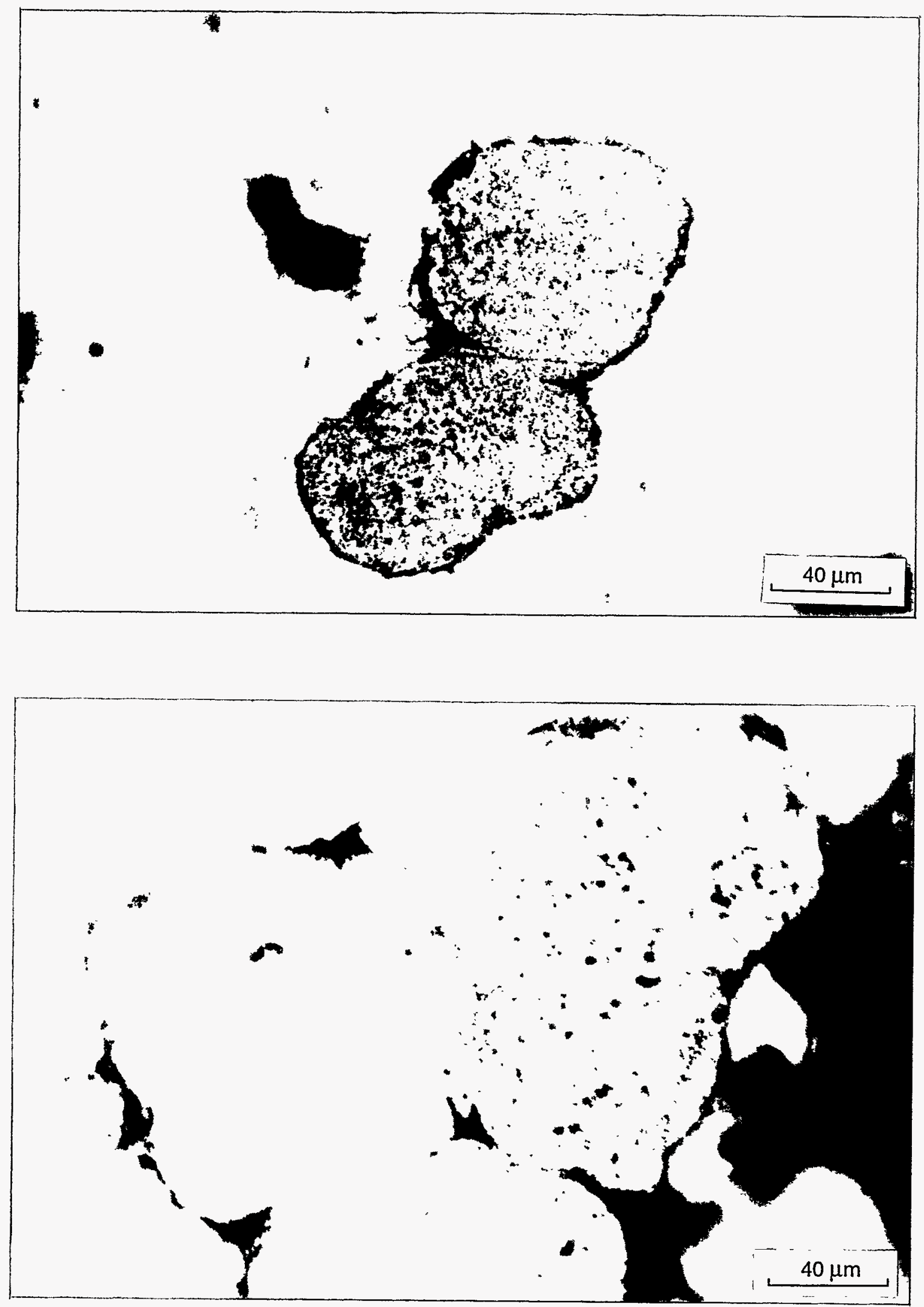

HANS-2, Sample \#1, $\mathrm{U}_{3} \mathrm{O}_{8}, 425^{\circ} \mathrm{C}$, Optical 


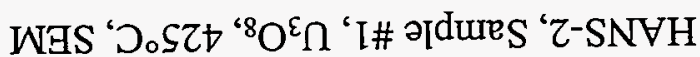
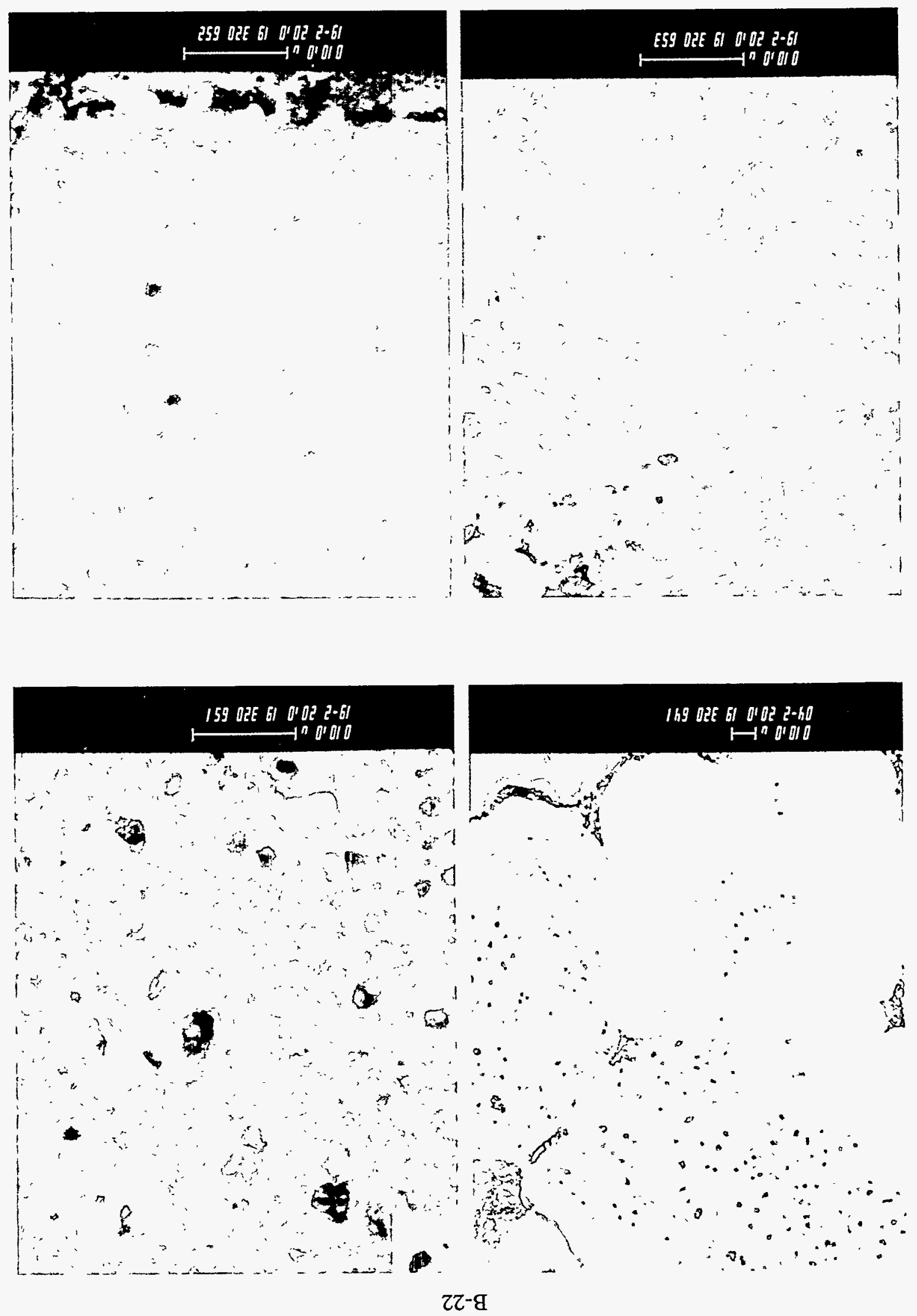


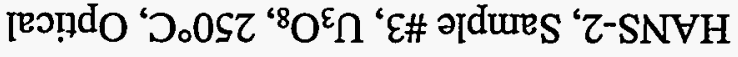

un ob
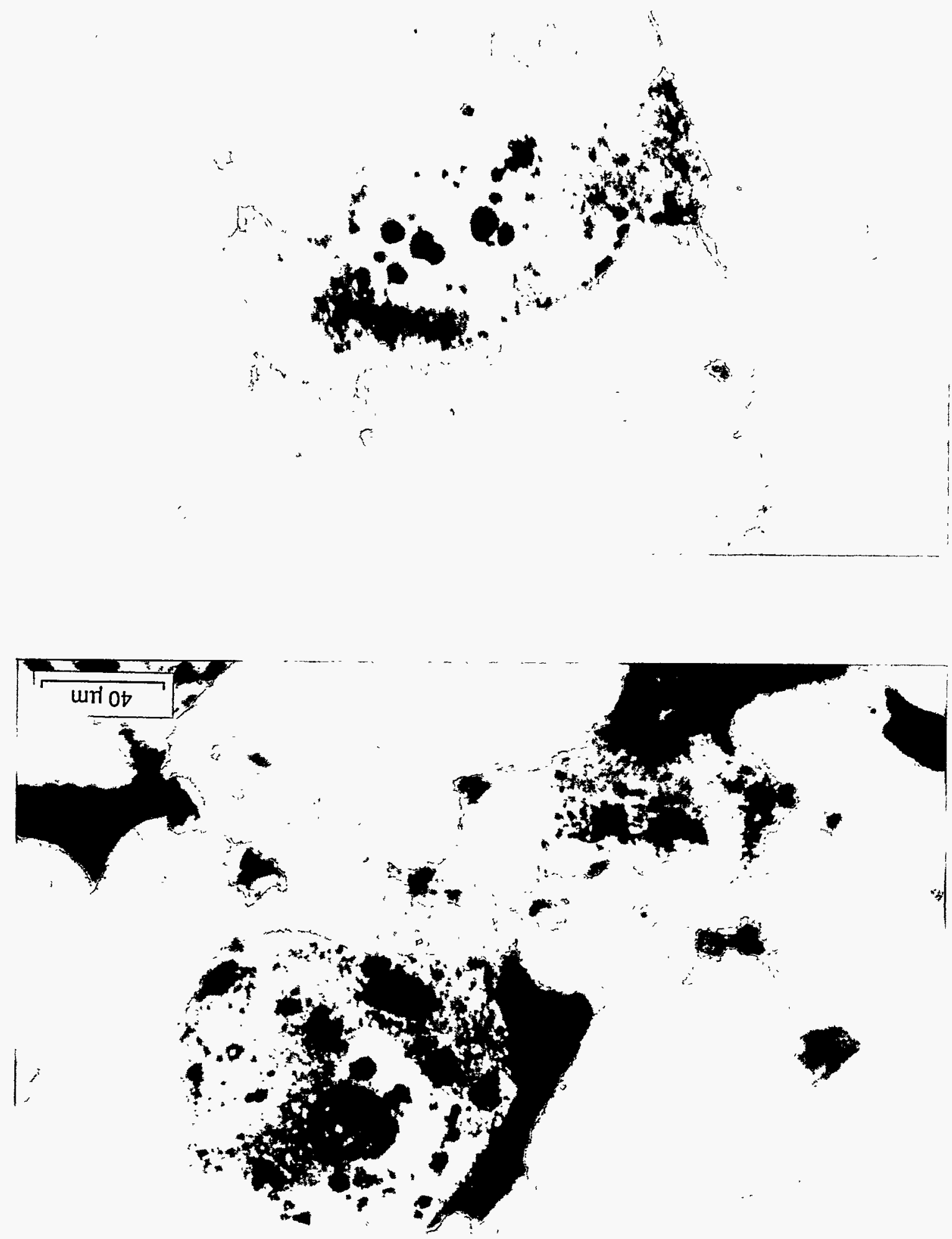
B-24
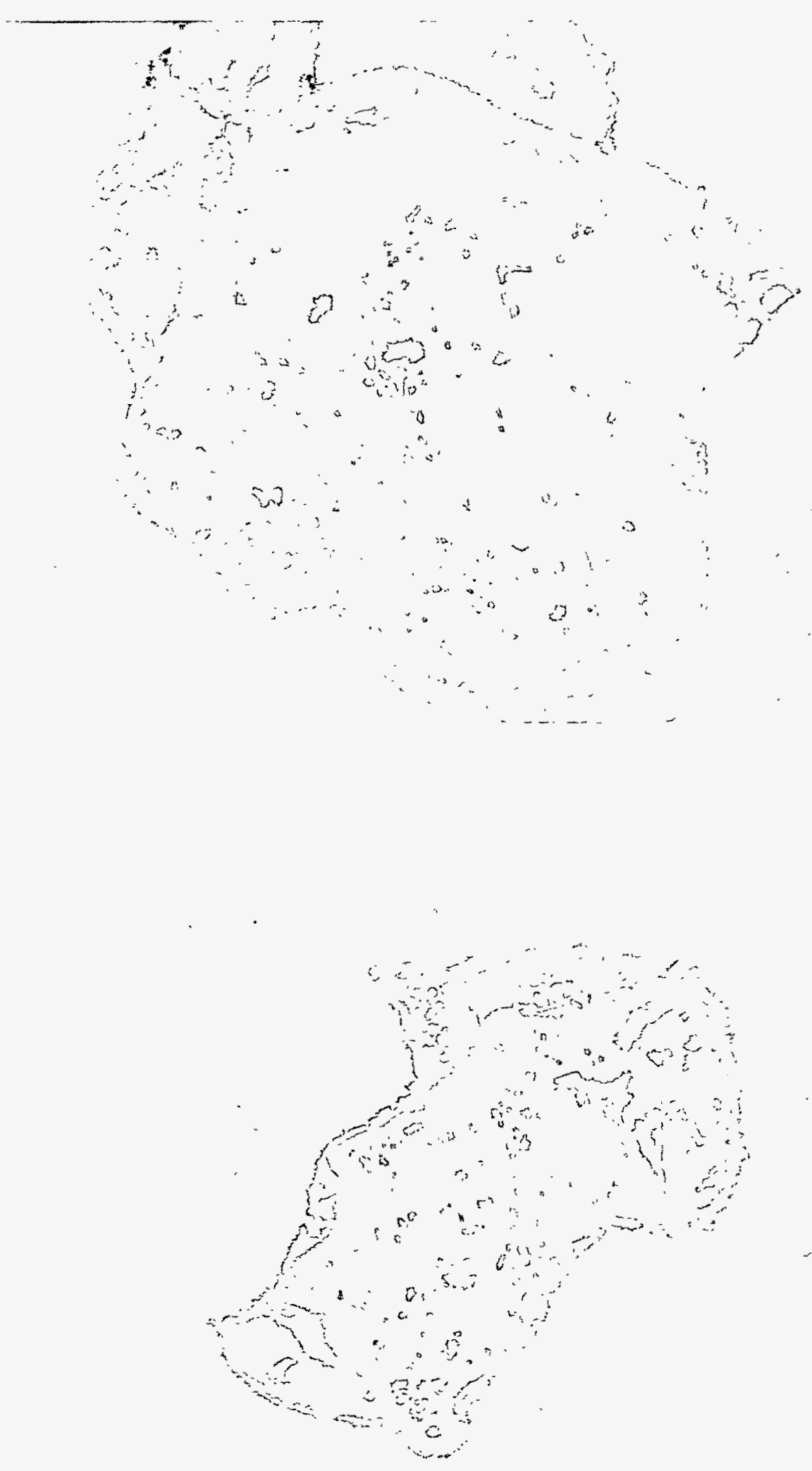

HANS-2, Sample \#8, $\mathrm{UAl}_{2}, 425^{\circ} \mathrm{C}$, Optical 
B-25
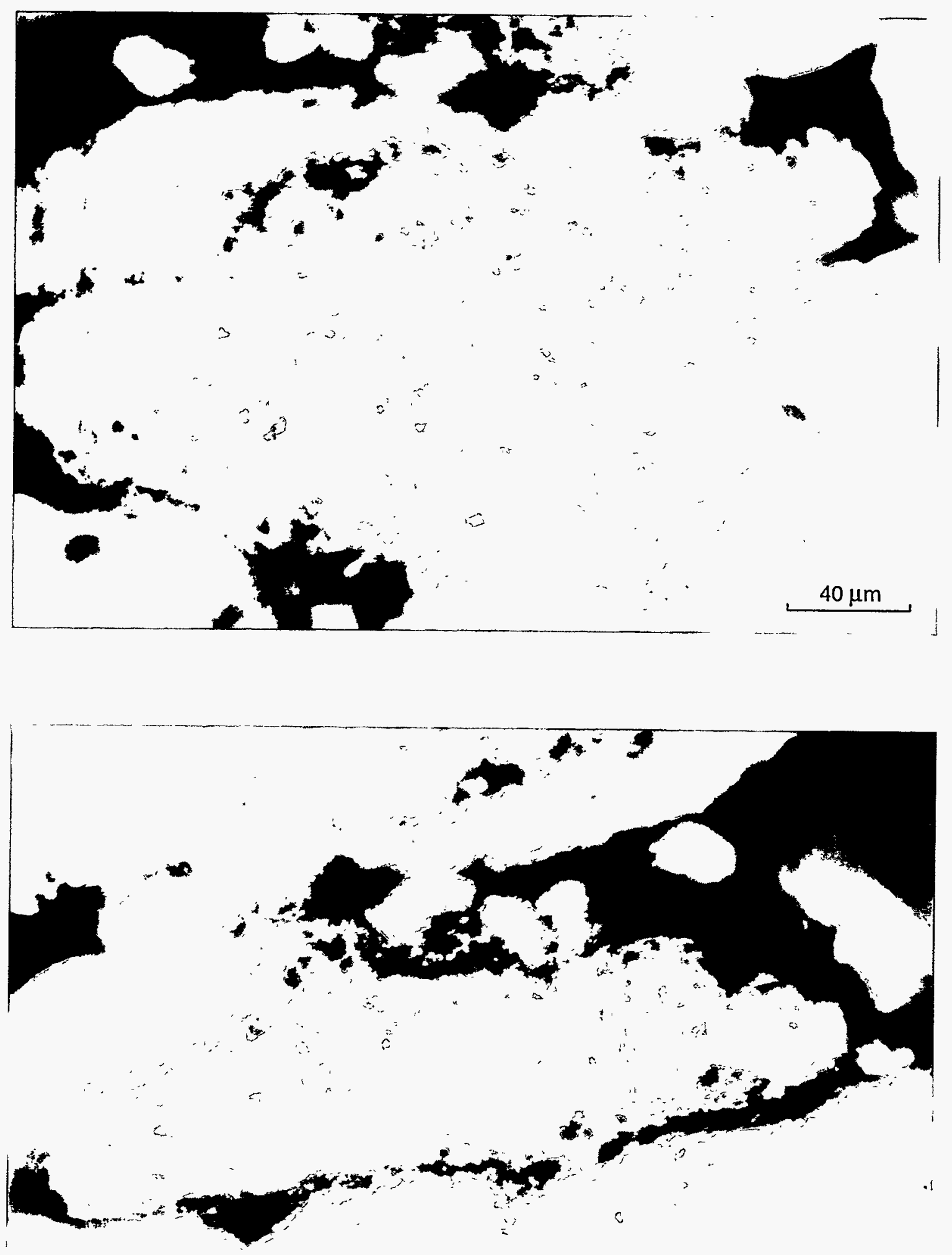

HANS-2, Sample \#6, $\mathrm{UAl}_{2}, 375^{\circ} \mathrm{C}$, Optical 
B-26
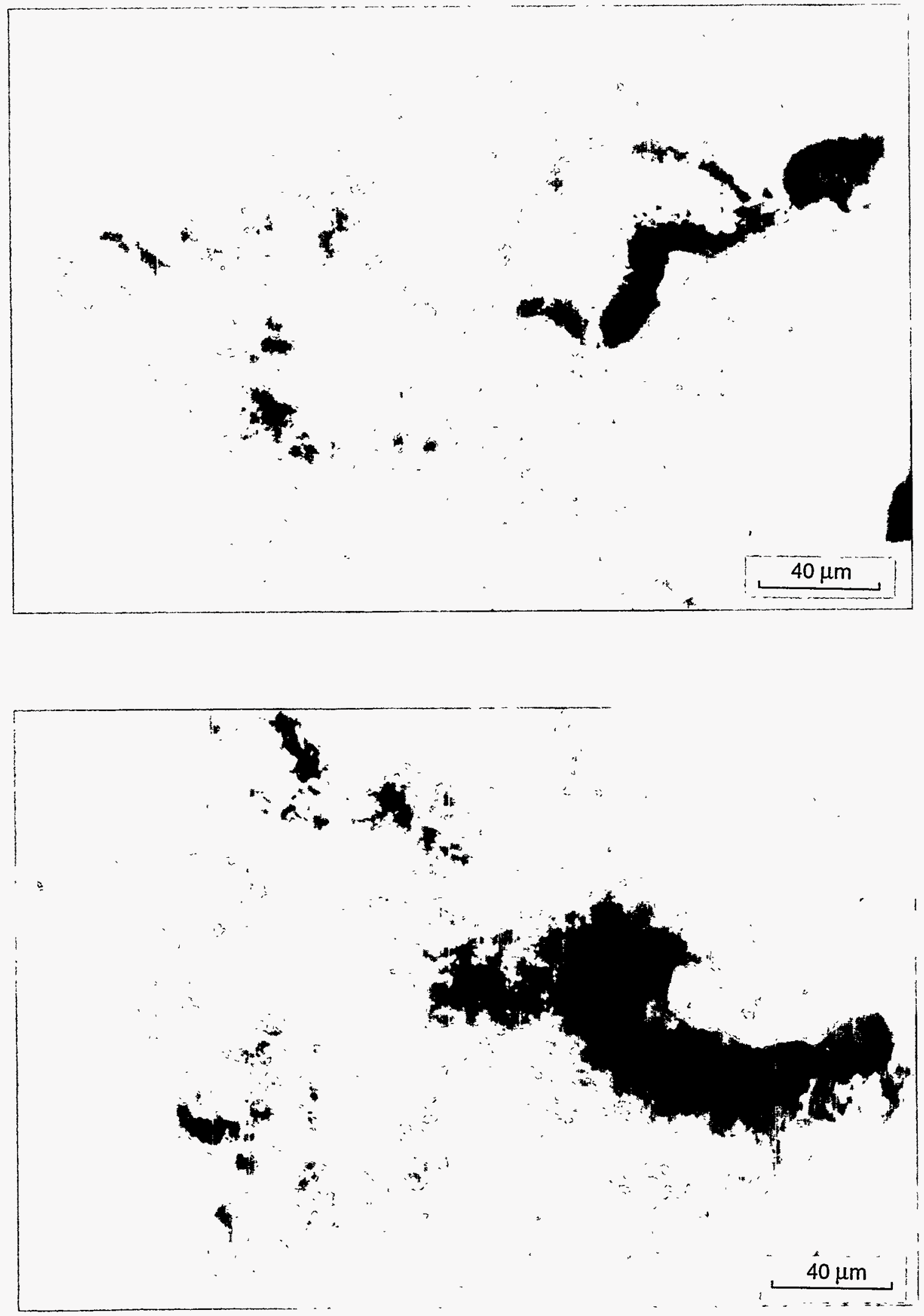

HANS-2, Sample \#17, UAl, $425^{\circ} \mathrm{C}$, Optical 
B-27
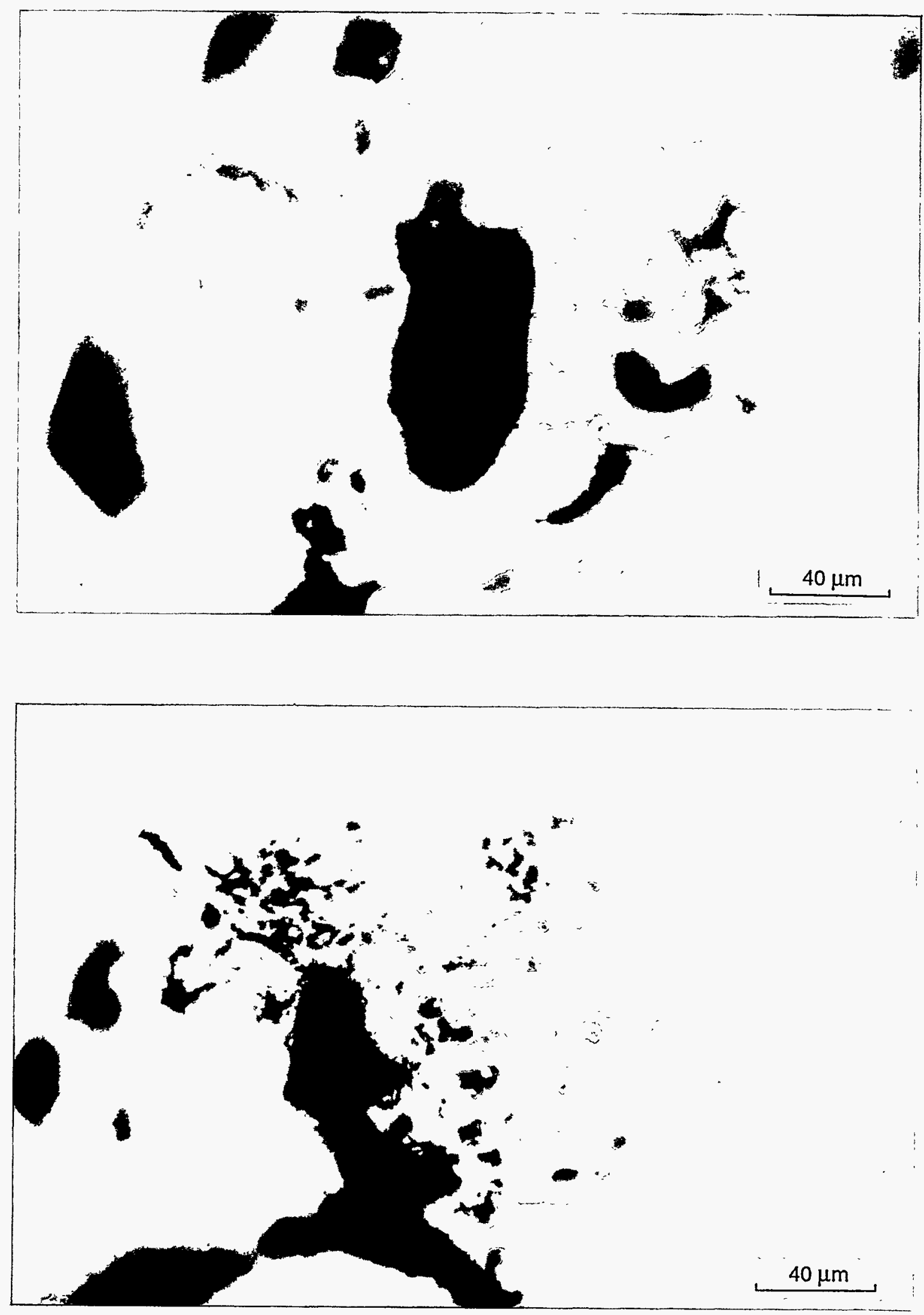

HANS-2, Sample \#12, $\mathrm{UAl}_{\mathrm{x}}, 375^{\circ} \mathrm{C}$, Optical 


\section{B-28}
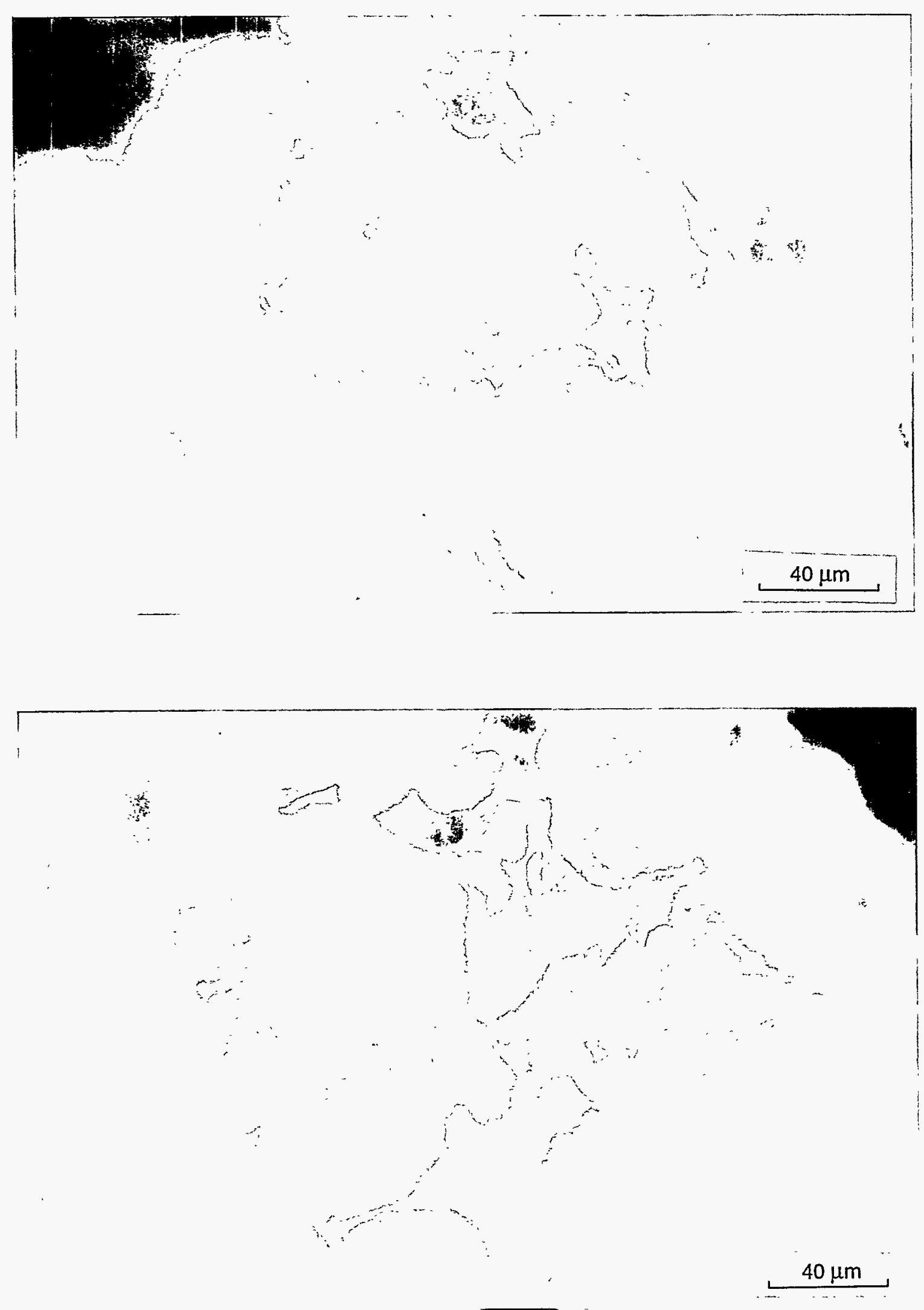

HANS-2, Sample \#15, UAl ${ }_{x}, 250^{\circ} \mathrm{C}$, Optical 

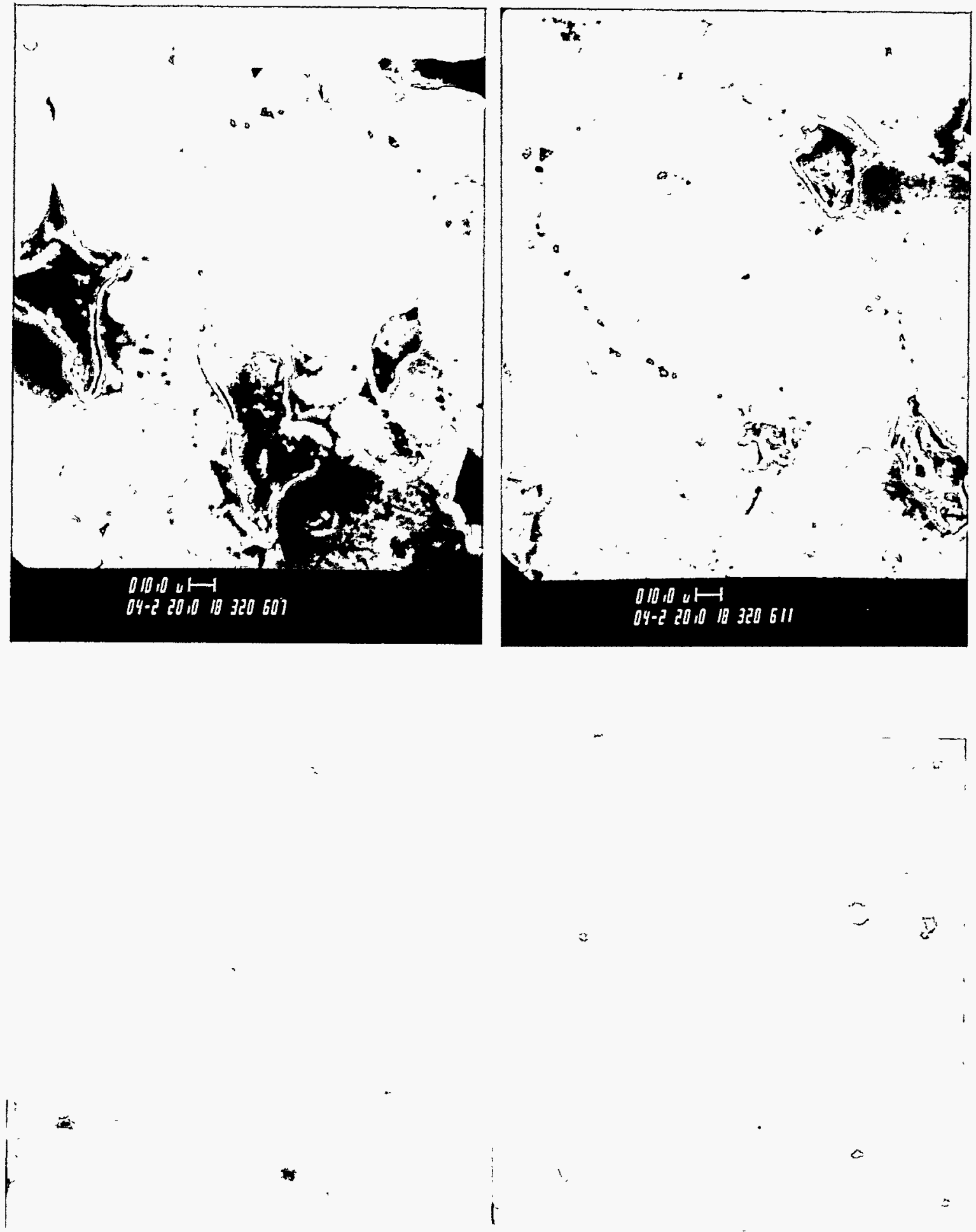

$+4$

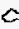

HANS-2, Sample \#15, UAl, $250^{\circ} \mathrm{C}$, SEM 



\section{INTERNAL DISTRIBUTION}

1. D. J. Alexander

2. B. R. Appleton

3. R. L. Beatty

4-8. J. H. Campbell

9. J. E. Cleaves

10-19. G. L. Copeland

20. K. Farrell

21. D. K. Felde

22. G. F. Flanagan

23. R. M. Harrington

24. J. B. Hayter

25. R. W. Knight

26. D. G. Morris

27. S. J. Pawel

28. C. C. Queen

29. P. L. Rittenhouse
30. R. B. Rothrock

31. J.D. Sease

32. D. L. Selby

33. R.P. Taleyarkhan

34. M. R. Upton

35. C. D. West

36. B. A. Worley

37. G. T. Yahr

38. G. L. Yoder

39. ORNL Patent Office

40. Central Research Library Document Reference Section

41. Y-12 Technical Library

42-43. Laboratory Records Dept.

44. Laboratory Records, RC

\section{EXTERNAL DISTRIBUTION}

45-49. G. L. Hofman, Argonne National Laboratory, 9700 Cass Avenue, Argonne, ㅍ 60439

50-54. J. E. Mays, Research and Test Reactor Fuel Elements, Babcock and Wilcox Co., P.O. Box 785, Lynchburg, VA 24505

55-59. B. W. Pace, Babcock and Wilcox Co., P.O. Box 785, Lynchburg, VA 24505

60-89. J. L. Snelgrove, Coordinator, Engineering Applications, RERTR Program, Argonne National Laboratory, 9700 Cass Avenue, Argonne, IL 60439

90. U. S. Department of Energy, ANS Project Office, Oak Ridge Operations Office, FEDC, MS-8218, P. O. Box 2009, Oak Ridge, TN 37831-8218

91-92. Office of Scientific and Technical Information, P.O. Box 63, Oak Ridge, TN 37831 
